\title{
Kommentar til Jesaja
}

$1-12$

Institut for Kultur og Samfund

Kirsten Nielsen

Monografi 




\section{KOMMENTAR TIL JESAJA 1-12}

\section{AF Kirsten Nielsen}

AARHUS UNIVERSITET 2009

Indhold:

INDLEDNING.

KAPITEL 1

Litterœr lœsning m.h.p. datidens lœsere og nutidens lœsere

Intertekstuel analyse 7

Forfatterens intertekster og lœserens intertekster

Det Nye Testamente som intertekst for Det Gamle Testamente.

Billedsproget i Jes 1-12.

Vingårdsbilledet.

Trœet som metafor: naturens orden

Jahve som anklager og dommer 
Jahve som far.

Historie og teologi

KAPITEL 2

Jesajabogen som litterœr helhed..

Ligheder mellem Jes 1,1-2,5 og Jes 65-66

Oversigt over Jesajabogens opbygning.

KAPITEL 3

Jesajabogen og den historiske kontekst

Den politiske udvikling fra 740'erne til 701 f.Kr.

Den politiske udvikling fra 612 f.Kr. til 539 f.Kr.

Skrivekunsten og nedskrivningen af profetorakler

Fortolkning, videreførelse og nedskrivning af Jesajas forkyndelse

De politiske grundvilkår og opfattelsen af Jahve som baggrund for genbrug af profetiske orakler

KAPITEL 4.

Jes $1,1-2,5$

Jes 3,1-15 
Jes 5,8-24

Jes 6,1-9,6.

Jes 6,1-13.

Jes 7,1-9

Jes 7,10-17

Jes 7,18-25

Jes 8,1-4

Jes 8,5-8

Jes 8,9-10

Jes 8,11-15

Jes 8,16-18

Jes 8,19-22

Jes 8,23-9,6

Jes $9,7-20$

Jes $10,1-32$

Jes 10,33-11,9

Jes 11,10-16.

Jes 12 


\section{INDLEDNING}

At skrive en kommentar til de tolv første kapitler af Jesajabogen rejser en lang rakke spørgsmål og krcever adskillige valg. Hvem henvender kommentaren sig til? Hvorfor netop disse kapitler ud af Jesajabogens 66 kapitler? Hvad er det for en type tekst? Hvilke metoder er relevante? Og hvad bliver der ikke plads til at beskceftige sig med?

Baggrunden for kommentaren er ønsket om at give de studerende i faget teologi en kommentar, der kan dckke de vigtigste behov til den del af uddannelsen i gammeltestamentlig eksegese, der omhandler den profetiske forkyndelse. I 2002 udkom Dansk Kommentar til Davids Salmer, som er beregnet på undervisningen i de gammeltestamentlige salmer, men der findes ikke en tilsvarende dansk kommentar til nogen af de profetiske skrifter. Blandt de forskellige profetskrifter har jeg valgt Jesajabogen. Grunden hertil er for det første, at dette profetskrift er velegnet til at vise en rœkke afgørende temaer i den profetiske forkyndelse. En stor del af Jes 1-12 afspejler en politisk anspœndt periode af Judas historie, sidste halvdel af 8. årh. f.Kr. Landet er truet af stormagten Assyrien, og på et tidspunkt er det også under pres fra kongerne i Samaria og Damaskus. Jes 1-12 indeholder den jesajanske tolkning af disse begivenheder som udtryk for Jahves reaktion på folkets frafald fra deres egen Gud. Ud over anklager og dom over folket og dets ledere indeholder disse kapitler desuden håb for fremtiden. Både dom og frelse indgår som centrale temaer i den jesajanske forkyndelse.

For det andet er de første tolv kapitler i Jesajabogen, ligesom Jesajabogens øvrige dele, velegnede til at vise, hvordan de profetiske ord både har kunnet fungere som aktuel forkyndelse i krisesituationer og har kunnet genbruges, nytolkes og videreføres ved senere lejligheder. Jes 1-12 indeholder nemlig ikke kun orakler fra 8. årh. f.Kr. Der findes senere udløegninger og tilføjelser, der viser, at forkyndelsen er blevet forstået som relevant ikke blot for de første tilhørere, men også for senere generationer. Videreførelsen af Jesajatraditionen i resten af Jes 1-39, Protojesaja, i Jes 40-55, Deuterojesaja, og i Jes 56-66, Tritojesaja, viser tilsvarende, at hvad der begyndte i 8. årh. f.Kr. er blevet bevaret, tolket og videreført i forbindelse med det babylonske eksil, hjemkomsten fra eksilet samt under genopbygningen af det jødiske samfund i 6. årh. f.Kr.

For det tredje skal det nœvnes, at også ud fra et lœngere perspektiv er den jesajanske forkyndelse central. Sammen med Davids Salmer er Jesajabogen på nytestamentlig tid blevet en af de 
afgørende intertekster for de nytestamentlige forfattere, når de ville formulere troen på, at Jesus var den Messias, som de gamle profetier talte om. ${ }^{1}$

Kommentaren er således skrevet ud fra den opfattelse, at Jesajabogen er en tekst, der er blevet til over en lœengere periode. De enkelte orakler er blevet til som aktuel forkyndelse, men de er blevet samlet, tolket og redigeret med henblik på nye situationer i tillid til, at profetordene stadig var aktuelle.

\section{Tilbage til indholdsfortegnelsen}

\section{KAPITEL 1}

\section{Litterœr lœsning m.h.p. datidens lœsere og nutidens lœsere}

Som bogen foreligger, er den et stykke litteratur, og den skal derfor lceses i overensstemmelse dermed. Men da Jesajabogen består af mange enkeltorakler, der hver iscer er blevet til i specifikke historiske situationer, vil en del af lœesningen dreje sig om at forstå det enkelte orakel ud fra den situation, det kan have vœret anvendt i. Undertiden kan det fremgå af teksten selv, hvem profetordet er henvendt til. Dette er fx tilfceldet i Jes 7, hvor profeten to gange, Jes 7,1-9 og 7,10-17, henvender sig til kong Akaz. Andre gange står det ene orakel efter det andet, uden at man klart kan afgøre, om de oprindelig har hørt sammen eller først redaktionelt er blevet bragt i forbindelse med hinanden (se eksempler herpå i kommentaren til Jes 1,4-9; 5,8-24 samt 7,18-25). Som lceser må man derfor hele tiden gøre sig klart, om man tolker en tekst i den foreliggende, littercre kontekst, eller man forsøger at nå tilbage til den betydning, oraklet kan have haft tidligere.

De enkelte orakler har således haft forskellige tilhørere/lœesere op gennem tiden, og alt efter den sammenhceng, de er blevet hørt i, er de blevet forstået forskelligt. Til de senere løesere hører den kristne kirke, der har mulighed for ikke blot at lœese oraklerne ud fra deres gammeltestamentlige kontekst, men også vil kunne inddrage Det Nye Testamente som hjœelp til tolkningen. Nogle kristne vil uden problemer acceptere den nytestamentlige fortolkning af de såkaldte messianske forjœttelser i Jesajabogen, fx Jes 7,14; 9,1-6 og 11,1-5, som forudsigelser af Jesus fra Nazareth. De vil således ikke skelne mellem den oprindelige betydning og den senere kristne nytolkning.

\footnotetext{
${ }^{1}$ Som baggrund for tolkningen af Jesajabogen som et profetisk skrift henvises til kapitlet om de profetiske bøger i Else Kragelund Holt og Kirsten Nielsen 1999, 210-227 samt til Marvin A. Sweeney 2005, 15-44.
} 
Andre vil ud fra deres historiske viden om teksternes tilblivelse og deres genre ikke mene, at disse forjœttelser, da de i sin tid blev fremsat, drejede sig om en sen fremtid. Ud fra en historisk betragtning må de gammeltestamentlige profetudsagn om den kommende konge af Davids slœgt forstås som udsagn om den nœste konge, der satte sig på tronen i Jerusalem, og som man dengang håbede ville vœre den rette konge, som kunne drive fjenderne på flugt og genoprette et jordisk Davidsrige. Det vil sige, at oraklet om den unge kvinde, der er gravid og skal føde en søn, som skal have navnet Immanuel, Jes 7,14, oprindelig har varet rettet til den œengstelige kong Akaz. Under den syrisk-efraimitiske krig har truslerne fra de to fjendtlige konger fået ham til at tabe modet. Hvad profeten trøster ham med er, at den unge kvinde venter et barn, og tolket i den sammenhaeng er det formentlig dronningen, profeten henviser til. Davids hus skal ikke gå til grunde, og tegnet derpå er, at der er en arving på vej (se nœrmere i kommentaren til dette sted).

Den nytestamentlige tolkning i Matt 1,23, hvor kvinden er jomfru Maria, og barnet er Jesus, må i det perspektiv opfattes som et eksempel på nytolkende genbrug af Jes 7,14. De gamle ord gentages ikke blot, de udlcegges på en ny måde af evangelisten. Ved at inddrage den gammeltestamentlige forjœttelse ønsker evangelisten at understrege, at Gud er en trovœrdig Gud, der opfylder sine egne løfter.

Når jeg taler om at lœse Jesajabogen som et stykke litteratur, betyder det derfor ikke, at vi så blot lœeser den, som om den havde én enkelt forfatter, at den var skrevet inden for en kort tidsperiode, og at den var skrevet med henblik på lœesere i det 21. århundrede. Men det betyder, at vi ikke er fœerdige med fortolkningen, når vi så korrekt som vel muligt har bestemt betydningen af et enkelorakel i dets oprindelige Sitz im Leben. Vi må også lcese enkeltorakler som del af den større komposition, Jes 1-12 eller Jes 1-39 eller hele Jesajabogen. I praksis vil vi i denne kommentar primcert lœese enkeltoraklerne inden for den kontekst og komposition, der udgøres af bogens første 12 kapitler, sådan som de nu foreligger. I et vist omfang er det muligt at forstå oraklerne ud fra en specifik historisk situation i 8. årh. f.Kr. Derudover vil det undertiden vœre relevant at spørge videre ud til bogen som helhed og til bogens virkningshistorie inden for kristendommen. ${ }^{2}$

Tilbage til indholdsfortegnelsen

\footnotetext{
${ }^{2}$ Jf. til Jesajabogens virkningshistorie Joseph Blenkinsopp 2006 samt Steve Moyise \& Maarten J.J. Menken (eds.) 2005.
} 


\section{Intertekstuel analyse}

Jesajabogens lange tilblivelseshistorie og efterfølgende virkningshistorie gør det relevant at introducere begrebet intertekstualitet. ${ }^{3}$ Begrebet kan bruges på mange forskellige måder. Nogle bruger det, når der i Det Nye Testamente citeres fra Det Gamle Testamente. I sådanne tilfclde fungerer det gammeltestamentlige sted og den kontekst, det er taget fra, som intertekst for den nytestamentlige tekst. Når evangelisterne fortœller, at et af Jesu korsord lød: "Elí, Elí! lemá sabaktáni? - det betyder: 'Min Gud, min Gud! Hvorfor har du forladt mig?'”, Matt 27,46, er det SI 22,2, der er interteksten. Men det kan diskuteres, om det så alene er de citerede ord, man skal tanke med i sin tolkning af Jesu lidelse og død, eller det er hele salmen, der skal vœre intertekst. For hvis det sidste er tilfœldet, så skal vi i Jesu korsord ikke blot høre et skrig om gudsforladthed, men medtcenke hele salmen. SI 22 begynder ganske vist med, at salmisten klager og kalder på den fravœrende Gud, men salmen slutter med, at han takker og lovpriser Gud, fordi Gud greb ind og hjalp ham. ${ }^{4}$

En tekst kan også fungere som intertekst, uden at den er direkte citeret. Ved hjœlp af et eller flere stikord, markører, der markerer forbindelsen til interteksten, kan lœeseren blive ledt på sporet af, hvilken anden tekst der nu skal tcenkes med i fortolkningen. Inden for Jesajabogen vil udtrykket tjener, fx Jes 42, 1; 49,3; 52,13, eller Herrens tjener, Jes 42,19, kunne fungere som en markør, der får lœeseren til at inddrage andre tekster, hvor dette udtryk anvendes, uanset om det anvendes på prcecis samme måde eller ej. Moses kaldes således ofte Herrens tjener, fx Deut 34,5; Jos 1,1; Jos 1,13; Jos 8,31. Samme udtryk bruges om David i SI 18,1 og 36, 1, ligesom Job i Job 1,8 kaldes "min tjener Job". I nogle tilfcelde er markøren så tydelig, at man ikke er i tvivl om, at forfatteren bevidst ønskede, at hans lœesere skulle inddrage den pågœldende intertekst, andre gange er det usikkert, om forfatteren selv har intenderet en sådan intertekst, eller det alene er lœseren, der inddrager den. Genbrugen af SI 22,2: "Min Gud, min Gud, hvorfor har du forladt mig?" er et sådant eksempel på, at de nytestamentlige forfattere inddrager en celdre tekst som intertekst og tolker den på en måde, som den gammeltestamentlige forfatter ikke havde til hensigt (jf. også drøftelsen af Jes 7,14 s. 113-115).

\footnotetext{
${ }^{3}$ Begrebet intertextuality går tilbage til Julia Kristeva. Jf. Julia Kristeva, Desire in Language. A Semiotic Approach to Literature and Art. Edited by Leon S. Roudiez. New York: Columbia University Press, 1980. Se i øvrigt til denne prœsentation af begrebet intertekstualitet Kirsten Nielsen 2000.

${ }^{4}$ Se ncermere om forholdet mellem Jesajabogen og Det Nye Testamente i John F.A. Sawyer 1996. Sawyer kalder Jesajabogen for det femte evangelium og understreger, at Det Gamle Testamentes virkningshistorie også hører med til studiet af Det Gamle Testamente.
} 
Når der i denne kommentar er mange bibelhenvisninger, er formålet at uddybe vores forståelse af datidens tankegang, så hvad der for datidens lœesere eller tilhørere var selvfølgelige forudscetninger, også kan indgå i den moderne lœesers forudforståelse. Ved på den måde at udpege relevante bibelske intertekster for Jesajateksterne mener jeg at kunne give bedre muligheder for at forstå den jesajanske forkyndelse.

Tilbage til indholdsfortegnelsen

\section{Forfatterens intertekster og lœserens intertekster}

Helt generelt må man sige, at fanomenet intertekstualitet forekommer stort set hvor som helst, vi lœser og fortolker en tekst. Ingen tekst bliver til uafhcengigt af andre tekster. Enhver tekst indgår $\mathrm{i}$ et netvœrk af tekster og får sin betydning derudfra. En forfatter bruger af sit litterœere forråd og peger dermed bevidst eller ubevidst på andre tekster, som hans eget bidrag står i gaeld til. Og på tilsvarende måde vil enhver lœser medbringe et netvœrk af tekster, som vi bevidst eller ubevidst vœlger ud af, når vi skal lœese en tekst og fortolke den. Forfatterens intertekster har vi kun mulighed for at finde frem til, hvis de er markeret i teksten, og vi har kendskab til de pågceldende intertekster.

Vore personlige intertekster har forfatteren af gode grunde ikke haft kendskab til, da han formulerede sin tekst. Men under fortolkningen kan disse intertekster meget vel komme til at påvirke vores forståelse af teksten. Derfor er det en vigtig del af fortolkningsarbejdet at gøre sig klart, hvilke intertekster vi inddrager i fortolkningen. Undertiden vil vore nutidige intertekster, som jo fx kan vœre en lœrebog om de historiske forhold på Sankeribs tid, vœre yderst nyttige som nøgler til at forstå fx Jes 1,4-9. Men moderne intertekster kan også fungere som fordomme, der på forhånd låser betydningen af teksten fast, så vi fx kun kan lœese teksten, sådan som kirkefaderen Luther lœste den.

Begrebet intertekstualitet er nyttigt, hvis man vel at mcerke skelner mellem, hvad forfatteren har intenderet af intertekster, og hvad senere tider har inddraget af intertekster i deres fortolkning af teksterne. I moderne litteraturkritik har der vœret en tendens til helt at ville se bort fra, hvad forfatteren eventuelt måtte have tcenkt på af intertekster. Andre vil, sådan som jeg gør det her, stadig operere med en forfatter, der har haft en scrlig intention med sin tekst. Det betyder ikke, at vi så altid kan afgøre entydigt, hvad der var forfatterens mening og intention. For dels kan vi ikke vare sikre på, at forfatteren netop får sagt, hvad han eller hun havde til hensigt, dels kan det ikke udelukkes, at der siges mere med den foreliggende tekst, end den oprindelige forfatter havde i tankerne. En teksts betydning kan derfor ikke begrœnses til alene at omfatte den intention, forfatteren kan have haft. 
Tekster indeholder betydningspotentialer, som først realiseres i mødet med lœserne, og her må vi skelne mellem de samtidige lœsere og de langt senere lœesere. Vi er derfor ikke fardige med at tolke en tekst, når vi har forsøgt at nå tilbage til den såkaldt "oprindelige betydning”.

Selv om der er vanskeligheder forbundet med at bestemme forfatterens intention, bør man gøre forsøget. Men hvad vi kender til tekstens "forfatter" er nu engang kun selve teksten og de spor eller markører, som findes i teksten, og som skal hjœelpe lœeseren til at inddrage bestemte intertekster. Min måde at arbejde intertekstuelt på vil derfor i et vist omfang svare til en traditionel historisk-kritisk analyse af, hvilke andre tekster den pågceldende tekst er afhcengig af og dermed i dialog med.

I Jes 1-12 vil det ofte vœre relevant at have nogle af Davids Salmer prcesente som mulige intertekster for tolkningen. I den protojesajanske forkyndelse spiller kongen en vigtig rolle, både positivt og negativt. I det centrale kap. 7 fortcelles det, at profeten Jesaja mødes med kong Akaz for at scette mod i ham under den syrisk-efraimitiske krig. To fjendtlige konger er på vej til at belejre Jerusalem med deres hcere. Kong Akaz gribes af angst og reagerer ved at inspicere vandforsyningen til Jerusalem, Jes 7,3. Profeten bliver sendt for at overbevise kongen om, at der ikke er grund til at gå i gang med den slags forberedelser, for de to konger er blot som to rygende stykker trce. Nok står de i spidsen for Aram/Damaskus og Efraim/Samaria, men kong Akaz bør tcenke videre og spørge sig selv om, hvem der står i spidsen for Jerusalem, Jes 7,7-9.

At profeten lœgger op til en sådan tœnken videre fremgår ikke direkte. Men strukturen i oraklet åbner mulighed for også at inddrage den tredje part: Juda med hovedstaden Jerusalem og med Jerusalems egen konge. Og om det så er kong Akaz selv, eller det er Gud som konge, det får lov at stå åbent. Men for at forstå, hvad der siges mellem linjerne, skal man inddrage de forestillinger, der knytter sig til Jerusalem, sådan som de er formuleret i fx SI 2. Her skildres netop en situation, hvor en gruppe konger gør oprør mod Jahve og hans konge. Men den egentlige konge, han som troner i himlen, ler ad dem. Og salmen fortscetter med at gengive det intronisationsorakel, kongen får ved sin tronbestigelse:

Jeg har indsat min konge

på Zion, mit hellige bjerg.

Og videre hedder det, at kongen er Guds søn, og at Gud derfor vil give ham folkene som ejendom. 
Med Gud som den egentlige konge behøver Jerusalems konge ikke at vare bange. Forestillingen om folkenes oprør og deres forsøg på at erobre Jerusalem kendes også fra Zionsalmerne, SI 46 og 48, hvor truslerne afvises, da Gud selv griber ind og redder sin by.

Når sådanne salmer inddrages som intertekster for Jes 7,1-9, bliver det klart, at kong Akaz' angst for fjenderne er udtryk for manglende tillid til Jahve. På samme måde vil det vare relevant at inddrage SI 2,7 med ordene til kongen "Du er min søn, jeg har født dig i dag" til tolkningen af Jes 7,14, hvor profeten forkynder for kong Akaz, at den unge kvinde er gravid og vil føde en søn. Med baggrund i det nœre forhold mellem Gud og kongeslœgten, som også kommer til udtryk i SI 89,2738 i løfterne om, at Davids slœegt skal bestå til evig tid, bliver det igen klart, hvor katastrofalt det er, at kong Akaz ikke tør vise tillid til Jahves løfter, men stoler mere på menneskelig magt (se ncermere i kommentaren til Jes 7).

En sådan tolkning af Jes 7 forudscetter, at forfatteren har haft kendskab til de forestillinger, vi møder i Salmernes Bog om kongen som Guds udvalgte. Men det vil også vœre muligt at inddrage tekster, som forfatteren ikke havde kendskab til, men som gennem sammenstillingen af Jesajabogen som helhed kan blive relevante for tolkningen. Det sker fx, når man lœser tilbage fra bogens slutning til dens begyndelse og derigennem gør den senere tekst til intertekst for den tidligere tekst. I Jes 65,25 genbruges orakler fra Jes 1 1,6-9 om ulven og lammet, der grœsser sammen. Jes 65,25 står i forlœngelse af løfterne om den nye himmel og den nye jord og indgår dermed i en eskatologisk kontekst, Jes 65,17-25. Det tidligere og velkendte er forbi, noget nyt bliver til, som er radikalt forskelligt.

Når man lceser tilbage fra Jes 65,17's ord om, at Jahve skaber en ny himmel og en ny jord, til Jes 1 1,6-9's skildring af fredsriget, vil det eskatologiske aspekt blive tydeligere. Omtalen af det fredelige samliv mellem dyrene er så ikke blot et billede på fredelige tilstande i al almindelighed, men beskrivelsen indgår i de eskatologiske forestillinger om en ny tid, hvor Paradistilstanden vender tilbage. Spørgsmålet er så blot, om den oprindelige forfatter også tœnkte i eskatologiske baner.

De ncevnte lœsemåder er alle mulige, men det er vigtigt at gøre sig klart, hvilken type lœsning man foretager, så man fx ikke tillœegger den oprindelige forfatter synspunkter, som hører en langt senere tid til. At en tekst har betydningspotentialer, som forfatteren ikke selv har intenderet, medfører ikke, at vi så kan tillœgge ham disse betydninger. Men påvisningen af, at ikke mindst billedrige tekster er åbne for nyfortolkning i ny kontekst, kan forklare, hvordan det har vœret muligt at genbruge gamle tekster og give dem ny betydning. Og det kan vel også delvis forklare, hvorfor de 
gamle tekster ikke er blevet betragtet som passé, men er blevet overleveret fra generation til generation og lœst i lyset af den aktuelle menigheds eller persons egen situation.

Tilbage til indholdsfortegnelsen

\section{Det Nye Testamente som intertekst for Det Gamle Testamente}

At lœseren ved at vœlge intertekster for sin lœsning får stor indflydelse på tolkningen bliver ikke mindst tydeligt, hvis man lœeser tilbage fra Det Nye Testamente og tolker gammeltestamentlige orakler om en kommende konge af Davids slœgt i lyset af evangeliet om Jesus.

Ved gudstjenester i Den Danske Folkekirke Langfredag mindes menigheden Jesu lidelse og død på korset. Der lœeses fra lidelseshistorien i Det Nye Testamente, men derudover anvendes som gammeltestamentlig lœsetekst efter anden tekstrœkke sangen om Herrens Tjener, der lider stedfortrœdende, Jes 52,13-53,12. Lœst i den oprindelige deuterojesajanske kontekst handler sangen ikke om Jesus, men enten om en person i datiden eller om folkets egne lidelser under det babylonske eksil. Ved den kristne gudstjeneste scttes sangen ind i en ny sammenhœeng og bliver intertekst for lidelseshistorien. Fra at vare en sang om Guds plan med Israel, bliver det til en sang om, hvad Jesu lidelse og død betyder.

Den gammeltestamentlige tekst bliver ikke dermed til en forudsigelse af Jesu lidelse. Tjeneren i Jes 53 erikke Jesus fra Nazaret, men den kristne menighed genbruger de gamle ord til at tolke Jesu lidelse og død som stedfortrœdende og dermed til at tolke, hvad Jesu liv og død betyder. Tjenersangen er ikke formet som en forjœttelse om en fjern fremtid. Det er derfor ikke korrekt at havde, at Jes 52,13-53,12 går i opfyldelse med Jesu lidelse og død. For det var ikke, hvad forfatteren havde i tankerne i 6. årh. f. Kr. Men efter Jesu død og opstandelse begyndte begivenhederne at give mening og skabe tro, når de blev tolket i lyset af tjenerskikkelsen. En sådan nytolkningen af Skrifterne finder sted på vandringen til Emmaus, Luk 24,13-35, ligesom Filip hjcelper den etiopiske embedsmand med at tolke sangen om Herrens Tjener om Jesus, ApG 8,26-39. ${ }^{5}$

Tilbage til indholdsfortegnelsen

\footnotetext{
${ }^{5}$ Se ncermere til brugen af Jes 52,13-53,12 i gudstjenesten i Kirsten Nielsen 2003.
} 


\section{Billedsproget i Jes 1-12}

Et af de trœk, som har vœret medvirkende til, at den jesajanske forkyndelse er blevet bevaret og viderefortolket, er de mange metaforer og sammenligninger, der findes i oraklerne. Billedrige udsagn kan netop genbruges og nytolkes i en anden kontekst, for billedsprog krœever aktiv medvirken af lœseren og er åbent for forskellige tolkninger.

Tilbage til indholdsfortegnelsen

\section{Vingårdsbilledet}

Det er karakteristisk for et sprogligt billede, at det hœvder, at noget er ens, men dog forskelligt. At noget ligner, betyder netop, at det ikke er identisk med. Når profeten i Jes 5,1-7 synger en kœrlighedssang om en vingård, så vil tilhøreren meget snart opdage, at der ikke er tale om en bogstavelig vingård, men om billedsprog. Kcerlighedssange handler scedvanligvis ikke om vingårde, men om kvinder. I Det Gamle Testamente møder vi i Højsangen netop vingården som metafor for en kvinde. I Højs 1,6 taler den kvindelige hovedperson om, at hendes brødre blev vrede på hende, fordi hun ikke vogtede sin egen vingård, dvs. sig selv (se også Højs 8,11-12). Denne brug af vingården som billede på kvinden har vœret forholdsvis velkendt, og tilhørerne har formentlig uden vanskeligheder kunnet tolke vingårdssangen som en sang om en utro kvinde, der til trods for cegtemandens omsorg ikke gav "œgte druer", men "vilddruer".

Enhver vil forstå, at kvinden på en rckke punkter er ligesom en vingård. Hun har brug for sin mands beskyttelse og omsorg, og hendes opgave er at sctte frugt, dvs. føde hans børn. Der er dog også forskelle. Hun er ikke en plante i bogstavelig forstand, hun står ikke stille på samme sted, hun kan tale, hun har sin egen vilje osv. Den, der hører et billedligt udtryk, skal derfor valge blandt de mange betydninger, der hører billedet til, hvilke der passer på kvinden, og hvilke der ikke passer.

Ethvert ord har en rœkke betydningspotentialer. Om trceer gcelder, at de er levende vœsener. De har rødder og krone. Nogle bœrer frugt, nogle er stedsegrønne, andre er løvfœldende. Nogle gror blot, uden at mennesker tager sig af dem. Andre dyrkes af mennesker og udfylder kun deres opgave optimalt, hvis deres ejer plejer dem, graver, fjerner sten, beskcrer dem og beskytter dem mod vilde dyr og tyve. Bruger man ordet vinstok bogstaveligt, så er alle de betydningspotentialer, som ordet indeholder, relevante (konjunkt brug). Bruges ordet billedligt, er der en del af dem, som ikke er relevante, fx når man taler om kvinder (disjunkt brug). 
Som oftest tcenker man ikke meget over, hvilke betydningspotentialer der er relevante, og hvilke der ikke er relevante, da mange billeder er velkendte. I vores egen tradition har vi vannet os til, at når den elskede kaldes en rose, så er det skønheden og duften og ikke tornene, der tcenkes på. Men netop fordi vi så ofte tolker billedsproget uden de store problemer, bliver vi overraskede, når det bruges anderledes, end vi er vant til.

Afslutningen på vingårdssangen er derfor også kommet som et chok for dem, der har hørt den for første gang. For i sangens sidste vers afslører profeten, at vingården er et billede på Israels hus og Judas mcend, dvs. et billede på dem selv. De er den vingård, der baerer ucegte druer i form af manglende ret og retfcrdighed.

At vingårdsbilledet er velegnet til genbrug fremgår af Jes 27,2-6, hvor der findes en ny version af den gamle sang, men nu med en helt anden holdning til vingården. Nu bliver den ikke blot passet og plejet efter alle kunstens regler, den bœrer også god frugt:

Til den tid skal Jakob slå rod,

Israel skyde op og blomstre;

de skal fylde hele verden med frugt.

Domsforkyndelsen er erstattet af frelsesforkyndelse, men den grundlaggende metafor, Israel som en vingård, er den samme. Nu ligger vœgten blot på vinstokkens naturlige måde at vœre vinstok på.

At et menneske kan sammenlignes med en vinstok, som bcerer frugt, kender vi ikke kun fra Det Gamle Testamente. Også i Det Nye Testamente genbruges vingårdsbilledet. Det sker fx i en rœkke lignelser, hvor vingården er billede på Guds rige, og mennesker er arbejdere i denne vingård (se fx Matt 20,1-16; 21,28-46). En anden måde at bruge billedet på er Joh 15,1-8, hvor Jesus er vinstokken og disciplene grenene, som alene kan bcere frugt, når de forbliver på vinstokkens stamme. Her er det den indbyrdes afhcengighed mellem grene og stamme, der står i centrum.

Skal man forstå disse billeder, er man selvfølgelig nødt til at have en vis viden om, hvad man forbandt med et trce dengang. Hvilke trceer fandtes der i området, og hvilken vœrdi blev de enkelte trœsorter tillagt? Man må kende den bogstavelige betydning af ord som trce og vinstok. Derpå må man undersøge, om der er sœrlige traditioner forbundet med trœer, som kan spille ind på den måde, billederne bruges på. Den gammeltestamentlige fortcelling om de to scerlige trœer i Paradisets Have, trœet til kundskab om godt og ondt og livets trce, er et eksempel på en sådan traditi- 
on, som undertiden kan danne baggrund for brugen af trœet som billede. Og endelig skal man analysere de enkelte steder i deres littercre kontekst for at se, om billedet bruges på traditionel vis, eller der er sket cendringer for at fremkalde en scerlig pointe.

Tilbage til indholdsfortegnelsen

\section{Trœet som metafor: naturens orden}

Vœlger man at bruge trœer som metafor for mennesker, fx en konge, så hører det med til forudforståelsen, at der er en vis orden i naturen, som trœer normalt følger. I Jobs Bog hedder det om trœet:

For et trœe er der håb,

hvis det fœldes, kan det skyde igen;

det holder ikke op med at scette friske skud.

Selv om rødderne i jorden er gamle,

og stubben dør i mulden,

gror det igen, så snart det mcerker vand,

og scetter grene som et nyplantet trce. Job 14,7-9.

En sådan naturlov giver håb for trcet ifølge Job, derimod ikke for mennesket, som netop ikke er som et trœe hos Job og derfor heller ikke får nyt liv, når det dør, Job 14,10. Trœets evne til at få nyt liv bliver til gengœeld udnyttet i Jesajabogen, hvor trœet bruges billedligt. I Jes 6,13 og 10,33-11,1 bruges billedet af en trœfœldning. Trœet er ved at miste livet, men trods fœeldningen spirer det igen, og sådan er det også med kongeslagten, Davids hus. Stubben indeholder trods alt hellig sced, Jes 6,13, og fra roden skal der skyde en kvist, Jes 11,1 .

Når man bruger billeder, er det for at overbevise tilhørerne eller lœeserne om, at noget forholder sig på en måde, som de delvis kender andre steder fra. Som det normalt er med trceer, sådan er det også med mennesker. Og fordi tilhøreren kender til naturens lovmœessighed, vil billedet normalt overføre denne lovmassighed til det, billedet taler om. Har man først accepteret metaforen som relevant, så overtager man også billedets måde at se verden på, hvad enten det drejer sig om billeder på Gud eller mennesker. 
Billeder bruges til at skabe nye måder at se verden på, men de kan også blive så velkendte, at de ikke lœengere siger noget nyt. De er blevet konventionelt lukkede, så vi kun hører, hvad vi plejer at høre gennem billedet. Bruges billedet i en ny sammenhceng, er det dog muligt at opdage betydningspotentialer, som man ikke tidligere har hœftet sig ved, men som nu bliver relevante. Ofte gœelder dette, når gammeltestamentlige udsagn tolkes kristologisk i Ny Testamente. Så er vinstokken ikke lcengere Israel, men såvel Jesus som disciplene, og grene og stamme bliver nu vigtige elementer i billedet og i tolkningen af forholdet mellem Jesus og disciplene. I det hele taget vil mange af de billeder, der i Det Gamle Testamente anvendes om Gud selv, få ny betydning i Det Nye Testamente, når de anvendes om Jesus (se fx billedet af den gode hyrde i SI 23 eller Jes 40,1 1 og i Joh 10,1 1- 16).

Sammenfattende må man sige, at de oprindelige orakler ikke blot er blevet udsat for reception, men også for transformation i den proces, der har ført til skabelsen af Jesajabogen. Og et af de trœk vi vil se på i kommentaren til Jes 1-12 er det billedsprog, der anvendes til at formulere den jesajanske forkyndelse, både når der tales om Jahve, og når der tales om mennesker.

Billedet af trœet har vist sig at vœre godt at tœenke med. Vi skal adskillige gange i Jes 1-12 møde denne metafor og se, hvor forskelligt den kan anvendes (se ncermere i kommentaren til Jes 1,29-31; 2,12-17; 4,2-6; 5,1-7; 6,12-13; 9,7-20; 10,16-19; 10,33-11,10 samt i Kirsten Nielsen, For et trce er der håb. Om trceet som metafor i Jes 1-39. København: Gad 1985).

Tilbage til indholdsfortegnelsen

\section{Jahve som anklager og dommer}

Mens trœet udelukkende bruges som billede på mennesker i Jesajabogen, er der et andet billede som hyppigt bruges om Jahve, nemlig billedet af en retssag, hvor Jahve er både anklager og dommer (se ncermere i Kirsten Nielsen 1977, 45 samt Kirsten Nielsen 1978). Også her galder det, at nogle af de betydningspotentialer, der er forbundet med en retssag, også gcelder for Jahve og for den retssag, han indkalder til: Der indkaldes vidner, som kan sikre, at alt går retfcerdigt til, Jes 1,2. Retsforhandlingerne begynder med fremscettelse af anklager mod den anklagede, Jes 1,2-3; 3,13-15, og sagen afsluttes med en kendelse, Jes 1,4-9; 3,16-4,1. Jahve har rollen som den, der fœlder dommen; men i modscetning til de retssager, vi kender til fra vores kultur, fungerer Jahve også som anklager.

En vigtig del af en retssag er naturligvis forsvaret, hvor den anklagede kan fremløgge bevis for sin uskyld. Men i de jesajanske retstaler mangler forsvarstalen. De anklagede har øjensynlig ikke noget at komme med til deres forsvar. Det kan i den sammenhceng diskuteres, om "kendelserne" i 
Jes 1,4-9 og 3,16-4,1 hører med til den oprindelige retstale eller er senere tilføjelser (se ncermere i kommentaren til disse steder). En af mulighederne er, at anklagerne i den oprindelige forkyndelse er blevet fremsat uden den afsluttende kendelse. Så må tilhørerne selv overveje, om de har noget at sige til deres forsvar, og om de fx ved at bekende deres skyld og gøre bod kan få dommeren til at lade nåde gå for ret; eller om de må se i øjnene, at dommerens kendelse ikke kan andet end falde negativt ud.

At også billedet af en retssag har vœret velegnet til at formulere forholdet mellem Jahve og verden fremgår desuden af de retstaler, der findes i Jes 40-55. Her genbruges billedet af en retssag $\mathrm{i}$ Jahves stridssamtaler med de fremmede folk og deres guder. Striden drejer sig om, hvem der har magten, Jahve eller de fremmede guder. Bevisførelsen går på, hvem der står bag de store politiske begivenheder, som har fundet sted tidligere, og ikke mindst på, hvem der har magten til også at gribe ind i fremtiden, Jes 41,1-5; 41,21-29; 43,8-13. Også uden for Jesajabogen findes eksempler på retstaler, fx SI 50; 82 og Dan 7,9-14. I Det Nye Testamente anvendes det samme billede, når der i den store scene i Matt 25,31-46 fortcelles om verdensdommen (jf. desuden Åb 20,11-15, hvor Gud dømmer alle mennesker efter deres gerninger).

\section{Faktaboks: Retstaleformen, Ríb-Pattern}

Rîb-Pattern er betegnelsen for den profetisk retstale/anklagetale. Julien Harvey ${ }^{6}$ har fremsat den tese, at der i 2. årt. f.Kr. har eksisteret et internationalt regelscet, som blev taget i anvendelse, når en vasal brød pagten med sin herre. Ifølge Harvey er der slående ligheder mellem breve fra pagtsherren til den troløse vasal og de profetiske retstaler, hvor Jahve optrceder som storherren og hans folk er den frafaldne vasal. Ifølge Harvey har den profetiske retstale haft følgende struktur:

1) Appel til himmel og jord og appel til alle om at høre efter.

2) Erklaring om Jahves ret til at handle, som han gør.

3) Anklage mod gudsfolket, der har vœret ulydigt mod pagten.

4) Forhør uden forventning om svar.

5) Anklagetale, normalt historisk begrundet, der opregner Jahves velgerninger og folkets utaknemmelighed.

6) Erklœring om de fremmede guders afmagt eller om det umulige i at genoprette den brudte forbindelse ved hjœelp af riter.

7) Erklcring om Israels skyld.

8) Trusler om ødeløggelse. Type A. Positiv befaling om, hvad der krceves for at forbindelsen kan genoprettes. Type B.

\footnotetext{
${ }^{6}$ Jf. Julien Harvey, Le Plaidoyer prophétique contre Israël après la rupture de l'alliance. Étude d'une formule littéraire de l'Ancien Testament. Bruges-Paris 1967.
} 
I praksis vil det dog vise sig, at kun nogle af disse led er anvendt i en profetisk retstale. Harvey regner her med 5 elementer, som er meget stabile, selv om et enkelt eller to kan mangle:

1) Forberedelserne til processen

2) Forhør uden forventning om svar

3) Anklagetale

4) Den officielle erklœring om anklagedes skyld

5) Fordømmelsen udtrykt i form af trusler og ikke domskendelse, Type A / Positiv befaling om, hvorledes de skal forholde sig, Type B.

Om de profetiske retstaler er direkte afledt af den internationale ret er dog stadig et åbent spørgsmål. Men Harveys analyser har peget på ligheder mellem den basale opfattelse af forholdet mellem en storherre og hans vasal, sådan som det kendes fra det hittiske materiale, og den opfattelse af forholdet mellem Jahve og Israel, som de profetiske retstaler giver udtryk for. I begge tilfœelde er der tale om et pagtsforhold med gensidige aftaler, der skal overholdes. Pagtsherren skal beskytte sin vasal, og vasallen skal adlyde sin herre. Derfor må pagtsherren i begge tilfcelde gribe ind, når vasallen bryder pagten. Det afgørende i analyserne af Rîb Pattern er dog, hvordan denne taleform bruges i den jesajanske forkyndelse, og hvilke forudsctninger tilhørerne/lœeserne har haft for at forstå den og det budskab, der formuleres i Rîb Pattern. Og her krœeves ikke kendskab til et bestemt internationalt regelscet. Hvad tilhørerne skal vide er, at Jahve er deres Gud. Jahve er som en konge, der krœver lydighed af sit folk. Som konge har Jahve ret til at straffe, hvis folket bryder sin del af pagten og stoler på andre magter (menneskelige eller guddommelige) end deres egen Gud (se ncermere i Kirsten Nielsen, Jahve som anklager og dommer. En undersøgelse af de profetiske retstaler (Rib-Pattern), Aarhus: TeolTryk 1977).

Tilbage til indholdsfortegnelsen

\section{Jahve som far}

Som laeser må man overveje, hvilken forudforståelse der ligger bag valget af en metafor. Når Jahve og Israel i en retsscene som Jes 1,2-3 skildres i billedet af en far og hans børn, indebcerer det en rœkke ting, som får betydning for brugen af billedet. Ud fra gammeltestamentlig tankegang består der en nœr forbindelse mellem en far og hans børn. Han er deres ophav, han har derfor ansvaret for deres daglige behov, mad og klader, men også for deres opdragelse, og han er den, der skal beskytte sine børn mod andre og føre deres sag, hvis de udscettes for overgreb. Omvendt er han også den, der skal straffe dem, når de er ulydige mod ham og dermed krœnker ham.

Så lœenge børnene er børn, består deres hovedansvar i at vise lydighed mod deres far, men med alderen udvides ansvaret. I De Ti Bud hedder det: "Ær din far og din mor, for at du må få et langt liv på den jord, Herren din Gud vil give dig.”, Ex 20,12. At cere betyder for det første at vise respekt i form af lydighed, men på lœngere sigt også at œre forcldrene ved at tage sig af dem, når 
de bliver gamle, ligesom de tog sig af børnene, da de var små. Der er en gensidig afhcengighed i forholdet mellem forceldre og børn. Det er ud fra en sådan tankegang, man skal tolke det jesajanske billede af Jahve i Jes 1,2-3. Med moderne øjne er det en autoritcr far, der forlanger lydighed af sine børn til gengceld for sin omsorg for dem. Når det bruges som billede på Gud selv i Det Gamle Testamente, kommer man da heller ikke uden om, at det indebœrer, at Jahve har autoritet. Det er således ikke to ligeberettigede parter, der indgår en aftale, men en far, der står over for og over sine børn.

Tilbage til indholdsfortegnelsen

\section{Historie og teologi}

At skrive en kommentar til Jes 1-12 krœever både valg og fravalg. Da forkyndelsen i Jes 1-12 så tydeligt knytter til ved historiske begivenheder i 8. årh.f.Kr., er det nødvendigt med en vis viden om de politiske og kulturelle forhold på den tid. Men da det er meget vanskeligt at datere enkeltoraklerne prœcist, vil det som oftest vœre de historiske forhold i store trœk, der kan bruges som ramme for fortolkningen.

Når vi i dag laeser Jes 1-12, skyldes det primart en teologisk interesse i det budskab, teksten har formidlet og stadig formidler. Når det er muligt at nå til et nogenlunde sikkert resultat, vil vi naturligvis drøfte de enkelte oraklers oprindelse og dermed den historiske situation, de i første omgang skal forstås ud fra. Men da redaktorerne ikke blot har indsamlet forskelligt materiale, men også har placeret det i en bestemt rœkkefølge, vil en af de afgørende opgaver for tekstfortolkeren bestå i at undersøge betydningen af den foreliggende tekstkomposition. Jes 1-12 er kun en lille del af det samlede vark, Jesajabogen. Men disse første kapitler i samlingen har på forskellig vis fungeret som udgangspunkt for resten af bogen. Disse kapitler giver derfor en god baggrund for videre studier $\mathrm{i}$ Jesajabogen og i genbrugen af centrale temaer herfra. Endelig hører det med til den teologiske interesse i teksten, at vi inddrager vœsentlige aspekter af virkningshistorien, i dette tilfœlde dog begrcenset til enkelte eksempler på Det Nye Testamentes reception og transformation af udsagn fra Jes 1-12. Teologien i Jes 1-12 samler sig om en rakke temaer:

1) Jahves kommende afstraffelse af folket p.g.a. dets synd, Jes $1,2-31 ; 2,2-4,1 ; 5,1-30$. Hertil hører den scrlige udgave af straffen i form af forhcerdelsestanken, Jes 6. 
2) Kritik af kongernes politiske tiltag. Et tydeligt eksempel herpå er den vanskelige situation under den syrisk-efraimitiske krig i 730'erne, hvor Jesaja forkynder nødvendigheden af at stole på Jahve og ikke indgå alliancer med fremmede stormagter, Jes 7. Også polemikken mod afgudsdyrkelse skal ses i denne sammenhceng, Jes 1,29-31 og 2,6-21.

3) Mistilliden til Jahve som tegn på menneskelig selvovervurdering, dvs. hovmod, Jes 2,6-21 og 10,519. Ved en sådan selvovervurdering scetter folket sig ud over den grundløggende orden, som Gud har skabt, og hvor det er Gud, der er den ophøjede.

4) Kritik af folkets kultiske aktiviteter, der gennemføres uden hensyn til de moralske forhold, Jes 1,1017. Socialkritik og kultkritik hører således sammen.

5) Håbet om en fremtid, som bygger på den rest, der trods alt er tilbage, samt på en kommende konge af Davids slœegt, der skal regere fra Zion, dvs. Zionteologi, Jes 6, 13; 11,1-9.

At Jesajas forkyndelse har forbindelse til templet i Jerusalem kan dels ses af, at kaldelsen af Jesaja til profet er placeret i templet i Jerusalem, dels afledes af hans sprogbrug og teologi. Der er således klare forbindelser til forestillinger, som kendes fra Davids Salmer, men som i Jesaja 1-12 aktualiseres m.h.p. den aktuelle politiske situation (se fx brugen af folkekampmyten i SI 2 og i Jes 7).

Gudsbilledet er prœget af tre forestillinger: Jahve er den hellige, Jahve er konge, og Jahve er dommeren (se fx Jes 6). Dette indebcrer, at Jahve er en aktiv Gud. Jahve regerer og styrer som en konge. Som den hellige stiller Jahve krav til sit folk. Og som dommeren må han faelde de nødvendige domme, hvad enten disse indebcerer straf eller frifindelse.

Tilbage til indholdsfortegnelsen

\section{KAPITEL 2}

\section{Jesajabogen som litterœr helhed}

De fœrreste forskere vil benœgte, at Jesajabogen består af oprindeligt selvstœendige helheder, som først efterhånden er blevet samlet til en bog med 66 kapitler. Traditionelt deles bogen op i tre dele: Jes 1-39, Protojesaja, Jes 40-55, Deuterojesaja, og Jes 56-66, Tritojesaja, (jf. den tyske forsker Bern- 
hard Duhms klassiske kommentar til Jesajabogen fra 1892). Men når det er sagt, står vi alligevel med et vœrk, som i sin nuvœrende form er udtryk for en bevidst komposition. Uanset tilblivelseshistorien er der ikke tale om en tilfceldig sammenstilling af de mange orakler. Tvœrtimod giver det god mening at lœse de 66 kapitler i sammenhœng som én bog (se nœermere i Knud Jeppesen 1988, 17-43).

Set i det perspektiv fungerer Jes 1,1-2,5 som en prolog. Det kan diskuteres, om prologen har varet tankt som prolog til alle 66 kapitler eller primart til Jes 1-39, Protojesaja. Tidsangivelsen i Jes 1,1 angår fx kun konger fra 8. årh. f.Kr. og dakker dermed ikke perioden under og efter eksilet. Ser man på forholdet mellem prologen og Jes 1-39, bliver det klart, at prologen tematiserer de vœsentligste temaer i Jes 1-39:

Anklage for synd, 1,2-3.

Dom, 1,4-9.

Falsk gudsdyrkelse og uretfcerdig behandling af de svage, 1,10-17.

Mulighed for redning, 1,18-20.

Jerusalems renselse, 1,21-28.

Fordømmelse af tilliden til de fremmede magter (i billedet af trœer) 1,29-31.

Zions ophøjelse og det kommende fredsrige, 2,2-5.

Selv om overskriften kun omfatter en del af den tid, Jesajabogen beskceftiger sig med, har redaktorerne tydeligvis ønsket at skabe en afrundet komposition. Kap. 65-66 fungerer som en afrunding af hele bogen, en epilog, idet disse kapitler griber tilbage til bogens $\varnothing v r i g e$ dele, herunder ikke mindst bogens begyndelse (se ncermere i Brevard Childs 2001, 542-547). Sammenligner vi Jes 65-66 med de temaer, der findes i Jes 1-12, viser det sig, at der er tale om en klar genbrug af protojesajanske motiver. Men der er gang på gang tale om en selvstcendig transformation af disse motiver. Dermed skabes der en cirkelstruktur, hvor vi vender tilbage til bogens begyndelse; men der er sket noget undervejs, derfor må der også vœre tale om nytolkning af de gamle forestillinger.

Tilbage til indholdsfortegnelsen 


\section{Ligheder mellem Jes 1,1-2,5 og Jes 65-66}

Jes 1,2: Jahve har opdraget sine børn, men Jes 65,2: Jahve har strakt handerne ud, de har brudt med ham.

men folket var genstridigt.

Jes 1,4: De har svigtet Jahve og ladet hånt Jes 65,3: Folket krcenker ustandselig Jahve. om Israels Hellige.

Jes 1,5-6: Deres krop er fuld af sår efter Ja- Jes 65,6: Jahve vil gengalde dem på deres hves slag krop.

Jes 1,9: Jahve har skånet en rest. Jes 65,8: Jahve vil ikke ødelœgge dem alle. Jes 1,26: Byen skal kaldes retfcerdigheds by. Jes 65,15: Jahves tjenere skal få et andet navn.

Jes 1,29: De elsker haverne, men skal få Jes 65,3: Krœenkelsen består i, at de ofrer i skam af dem. haverne.

Jes 2, 1-4: Vandringen til Jahves bjerg. Jes 66,18-21: Folkenes skal komme til Jerusalem, Jahves hellige bjerg.

At det ikke blot er genoptagelse, men nyformulering af celdre udsagn er tydeligt. Det er ikke de samme gloser, vi genfinder i Jes 65-66. Kun et enkelt sted er de to tekstdele også glosemcessigt så tœt på hinanden, at der er tale om et delvist citat. Det gœlder genoptagelsen af dele af Jes 11,6-9 i Jes 65,25:

Ulven og lammet grœsser sammen,

løven œder strå som oksen;

men slangens føde er støv.

Der findes hverken ondskab eller ødelceggelse på hele mit hellige bjerg, siger Herren. 
Disse eksempler viser, at der ligger redaktionelle overvejelser bag ved struktureringen af Jesajabogen. Som teksten foreligger, er den et stykke litteratur med prolog og epilog, og selv om størstedelen er poesi, kan man også tale om en vis form for handlingsgang gennem bogens tre hoveddele. Jesajabogen handler om Jahves kamp for at få sine egne børn til at holde sig til ham og adlyde hans ord. Midlerne hertil er dels de mange ord, Jahve sender for at advare, formane og trøste, dels de historiske begivenheder i form af nederlag i krig såvel som befrielse fra fjender og hjemkomst til deres eget land med mulighed for at genopbygge samfundet omkring et nyt tempel.

Dette forløb formidles med brug af en lang rakke forskellige taleformer, der hver på deres måde bidrager til handlingsgangen. En vigtig taleform er, som nœvnt, retstalen, hvor Jahve optrœder som den, der anklager sit folk, men også som den, der kan dømme eller frikende, fx Jes 1,2-3 og 3,13-15 (se også omtalen af retstalerne i Deuterojesaja s. 181).

Inden for Jes 1-66 findes der tydelige tegn på, at bogen bl.a. er sat sammen af allerede foreliggende afrundede dele. Således må Jes 1-12 oprindelig have vœret formet som en selvstcendig helhed, idet Jes 12 fungerer som en konklusion på bogens første 11 kapitler (se narmere i analysen af Jes 12). Jes 36-39 udgør en klart afgrœenset fortclleenhed, som er hentet fra 2 Kongebog 18,1320,19 og derpå placeret på overgangen til Deuterojesaja. En nœrlœesning af Jes 40,1-11 og Jes 55,6-13 vil desuden vise, at der her er tale om en cirkelkomposition (inclusio), der omkranser det deuterojesajanske afsnit af bogen (jf. Knud Jeppesen 1989, 74).

Tilbage til indholdsfortegnelsen

\section{Oversigt over Jesajabogens opbygning}

Det redaktionelle arbejde med Jesajabogen viser sig også i selve struktureringen af bogen (jf. Marvin A. Sweeney 2005, 51-52). I hovedtrcek består Jesajabogen af følgende afsnit:

\section{Protojesaja}

Jes 1-12:

Jes 1,1-2,5: Prolog, der sammenfatter hovedpunkterne i forkyndelsen: anklage, dom og frelse. Jes 2,6-5,30: Primœert domsforkyndelse, der begrunder Jahves vrede og hans ret til at straffe sit folk. Jes 6,1-9,6: Profetens scrlige opgave: at forhcrde folket, så det afviser Jahves frelsestilsagn. Jes 9,7-11,16: Domsforkyndelse, der slutter med løfter om et kommende fredsrige. Jes 12: Takkesalme, der afrunder afsnittet ved at takke, fordi Jahves vrede er forbi. 
Jes 13-23: Orakler mod fremmede folkeslag.

Jes 24-27: Fremtidsvision om verdens undergang og Israels frelse.

Jes 28-35: Domsforkyndelse, der slutter med frelsesforkyndelse for Jerusalem.

Jes 36-39: Beretning om Sankeribs angreb på Jerusalem og forudsigelse af eksilet.

\section{Deuterojesaja}

Jes 40-55: Forkyndelse af hjemvendelse fra eksilet og genopbygning af Jerusalem.

\section{Tritojesaja}

Jes 56-66: Formaning om overholdelse af pagten med Jahve og løfter om Jerusalems frelse.

Jesajabogen begynder med en lang rœkke anklager og domsudsagn, der kan forklare, hvorfor Jahve måtte straffe sit tungnemme folk. De udviste ikke den lydighed, som et barn skylder sin far, Jes 1,2-3. Ja, de tog end ikke imod Jahves frelsestilbud, hvilket eksemplificeres ved kong Akaz' afvisning af Jesajas forkyndelse, Jes 7-8. Først efter den nødvendige straf vil den rest, der er vendt tilbage til Jahve, opleve nye tider under en fredskonge, Jes 11, og folket vil kunne bryde ud i takkesang, Jes 12. Omfangsmassigt svarer dette første afsnit i Protojesaja til omfanget af flere af de små profetskrifter, fx Amos eller Hosea. Og ligesom Amos og Hosea indeholder det både megen domsforkyndelse og en positiv afslutning. Vi ved dog ikke, om disse 12 kapitler på et tidspunkt har fungeret som et selvstcendigt profetskrift.

Oraklerne mod de fremmede folkeslag, Jes 13-23, understreger ligeledes Jahves frelsesvilje over for sit eget folk, et motiv der videreføres i den såkaldte Jesajaapokalypse, Jes 24-27. Med kap. 28-35 gentages kombinationen af doms- og frelsesforkyndelse, mens den følgende beretning om Sankeribs forgœves belejring af Jerusalem i 701 f.Kr., Jes 36-39, fungerer som overgang til den deuterojesajanske frelsesforkyndelse i Jes 40-55.

At beretningen om assyrernes belejring af Jerusalem skal fungere som overgang til den langt senere hjemkomst fra Babylon kan bl.a. ses af, at den slutter med en forudsigelse af eksilet, Jes 39,6-7. Beretningen i Jes 36-39 svarer stort set til 2 Kong 18,13-20,19 og gengiver det deuteronomistiske syn på begivenhederne, hvor forudsœtningen for Jahves frelsende indgreb er genoprettelsen af forholdet til Jahve gennem anger og bod. Ved at indføje fortcllingen om Jerusalems belej- 
ring netop her kan redaktorerne også pege på forudsctningen for, at Jahves vrede ophører og erstattes af trøst. Folket skal lœre af historien. Det lykkelige udfald af belejringen i 701 f.Kr., som står i skarp kontrast til babylonernes ødelœeggelse af Jerusalem i 587 f.Kr., kan således vœre med til at vise såvel Jahves magt som Jahves frelsesvilje. Jes 40-55 fungerer derfor også som det profetiske svar på det anfœgtede spørgsmål om Jahves magt og Jahves vilje til at tage sig af sit eget folk (se nœrmere i afsnittet om Deuterojesaja s. 189-193).

Også sprogligt er der tydelige forbindelseslinjer mellem Protojesaja og resten af bogen. Jes 40,1-2 genoptager motivet med Guds vrede og trøst, som i Jes 12,1 fungerer som en sammenfatning af hovedindholdet af Jes 1-12 (se også trøstemotivet i Jes 49,13;51,3.12; 66,13-14). Kaldelsen af profeten i Jes 6 har sin pendant i Jes 40. Zion er et gennemgående motiv i hele bogen, Jes 1,12,5; 40,2; 66, ligesom betegnelsen Israels Hellige om Jahve er fœlles for Jesajabogen (se i øvrigt s. 189-193 om Jes 40 og den deuterojesajanske forkyndelse).

Med Jes 56-66 genoptages den interne kritik af misligholdelsen af pagten, som også kendes fra Jes 1-12, men med stcrk understregning af muligheden for at vende om og få del i den kommende herlighed, Jes 2,1-5 og Jes 60 samt Jes 11,1-9 og Jes 65,25.

Tilbage til indholdsfortegnelsen

\section{KAPITEL 3}

\section{Jesajabogen og den historiske kontekst}

Jesajabogen omfatter 66 kapitler, der alle tilskrives profeten Jesaja. Ifølge overskriften i kap. 1 var Jesaja, Amos' søn, aktiv under fire judœiske konger, Uzzija, Jotam, Akaz og Hizkija. Disse konger kan tidsfcestes til sidste halvdel af 8. årh. f.Kr. At også en hel del af Jes 1-12 beskceftiger sig med denne politisk urolige periode fremgår fx af kapitlerne 7-8. Her peger bl.a. navnestoffet på begivenheder under den syrisk-eframitiske krig (734-732), hvor aramaeerkongen Resin fra Damaskus og Nordrigets konge, Peka, fra Samaria, angriber Jerusalem i håb om at kunne få kong Akaz til at tilslutte sig en koalition mod assyrerne. Skildringen af den belejrede by i Jes 1,8, henviser formentlig til en anden 
vigtig begivenhed, assyrerkongen Sankeribs belejring af Jerusalem i 701 f.Kr. Ud fra sådanne nøglesteder forsøger forskerne at nå frem til en datering af de øvrige orakler i Jes $1-12{ }^{7}$

Tilbage til indholdsfortegnelsen

\section{Den politiske udvikling fra 740'erne til $701 \mathrm{f.Kr}$.}

Den periode, som profeten Jesaja er forbundet med, er udenrigspolitisk prceget af truslen fra assyrerne. I 745 f.Kr. bestiger Tiglat Pileser III tronen som hersker over det nyassyriske rige. Med ham indledes en ekspansionspolitik, der under de følgende fem konger fører til dannelsen af et imperium, som omfatter hele den frugtbare halvmåne, fra det mesopotamiske område omkring Tigris og Eufrat i øst, over dele af Lilleasien i nord, ned langs Middelhavskysten i vest med hele det syriskpalœstinensiske område til og med Egypten i syd. Riget består til slutningen af 600 tallet.

Jesajas kaldelse til profet dateres i Det Gamle Testamente til kong Uzzijas dødsår, 744 f.Kr., og falder således nogenlunde sammen med Tiglat Pileser Ill's tronbestigelse. Når det i Jes 6,1 angives, at Jesaja havde sin vision på netop dette tidspunkt, skal det ses ikke blot som en understregning af, hvor stor en rolle den udenrigspolitiske situation har spillet for den jesajanske forkyndelse, men også som en markering af, at nu står kampen mellem profeten, som reprœsenterer den Jahve, der sidder på sin trone i Jerusalems tempel, og den fremmede storkonge. Det afgørende politiske spørgsmål for Israel og Juda har varet, om de skulle underkaste sig assyrerne og betale tribut til gengœld for at opnå status som vasal, hvilket ville sikre, at konge og land beholdt en vis selvstœndighed, eller deres konge skulle tage kampen op mod overmagten med fare for at blive afsat og erstattet med en lydkonge eller en assyrisk guvernør. Det fremgår af såvel Kongebøgerne, 2 Kong 15,19, som af assyriske optegnelser, at kong Menahem af Israel ligesom kongen af Damaskus fra 738 f.Kr. betalte tribut som assyriske vasaller.

På den baggrund slutter de to vasaller sig sammen mod assyrerne. Kongen i Damaskus i Syrien er Resin, mens det i Israel (Nordriget også kaldet Efraim) er Peka, Remaljas søn, der sidder på tronen. Tidspunktet for deres oprør faldt sammen med, at Tiglat Pileser III var i gang med en større militcr ekspansion ude langs Middelhavet for at erobre Gazaområdet og dermed skaffe sig en base over for Egypten. For at sikre sig mod at have Juda som potentiel modstander kontakter de kong

7 Vedrørende spørgsmålet om Gammel Testamente som kilde til Israels historie se Niels Peter Lemche, Det Gamle Testamente mellem teologi og historie. Den historisk-kritiske bibelforsknings storhed og fald, Frederiksberg: Anis 2008. 
Akaz af Juda og forsøger at overtale ham til at deltage i oprøret mod assyrerkongen. Akaz, som på dette tidspunkt ikke er assyrisk vasal, afslår, da han nœppe har noget at vinde ved at lœgge sig ud med assyrerne. Peka og Resin opgiver dog ikke, men forsøger at presse Akaz til at gå med. Ved at sende tropper mod Jerusalem forventer de at kunne tvinge Akaz med ind i koalitionen. Hermed begynder den såkaldt syrisk-efraimitiske krig, med den syriske konge Resin og den efraimitiske konge Peka på den ene side og Judas kong Akaz på den anden side. Og som en konstant trussel over alle tre konger lurer stormagten Assyrien, som nœppe kunne forventes at lade det gå upåagtet hen, at vasalkonger gjorde oprør og undlod at betale den aftalte tribut.

Begivenhederne er beskrevet dels i 2 Kongebog 16 dels i Jes 7. Af Jes 7,4-6 fremgår, at Peka og Resin havde planer om at udskifte Akaz med en loyal lydkonge, som kunne støtte dem i oprøret mod assyrerne. I 2 Kong 16,7-20 fortcelles det, at Akaz vœlger den udvej selv at henvende sig til assyrerne om hjcelp og som tak herfor blive vasal og tributpligtig til assyrerkongen. Assyrerkongen vender sig til gengœeld i 733 f.Kr. mod de to oprørere. Damaskus bliver kort efter vasal under assyrerne, og Resin drcebes. Også Israel rammes af Tiglat Pileser Ill's vrede. Byer som Hazor og Megiddo ødelœgges, men Samaria skånes foreløbig, så den kan bruges som led i opbygningen af en rœkke stødpudeområder mod egypterne. Nordriget bliver assyrisk vasalstat, idet assyrerkongen opretter tre assyriske provinser, Dor, Megiddo og Gilead (se omtalen af de tre områder i Jes 8,23). Hosea indscettes som lydkonge, og Peka drcebes som straf for oprøret. Da Tiglat Pileser III dør i 727 f.Kr., benytter Nordrigets konge, Hosea, lejligheden til et oprør mod assyrerne, men udfaldet er katastrofalt. Efter tre års belejring falder Samaria i 722 f.Kr., 2 Kong 17,3-6 samt 18,9-12. Dele af befolkningen deporteres, 2 Kong 17,23-24, samtidig med at andre assyriske undersåtter flyttes til de erobrede områder i Nordriget (jf. holdningen til samaritanerne i Det Nye Testamente, hvor Jesu positive holdning til dem står i modstrid til den gœngse opfattelse af dem som halvjøder).

Nordrigets undergang har uden tvivl givet anledning til blandede følelser i Juda. Glœden over selv at vœre sluppet billigere end Nordriget har stået over for frygten for, at også Juda skulle blive erobret af assyrerne. Kong Akaz valgte fortsat at føre en forsigtig politik over for assyrerne, men hans søn Hizkija, som muligvis allerede i 728 f.Kr. blev medregent, vœelger, da hans far er død i 715 f.Kr., en ny kurs. I 713 f.Kr. deltager han sammen med Egypten og filistrene i et oprør, Jes 20, som kommer til at koste ham nogle af de vestlige judceiske områder.

En storkonges død skaber ofte uro blandt vasallerne, der håber at kunne frigøre sig, inden den nye konge for alvor har fået sat sig på magten. Da assyrerkongen Sargon II dør i 705 f.Kr., kom- 
mer det derfor igen til oprør blandt vasallerne, herunder Hizkija af Juda. Efterfølgeren Sankerib får slået oprøret ned i 701 f.Kr. I Det Gamle Testamente fortcelles der om, hvordan Sankerib erobrer alle Judas befœestede byer. Han belejrer Jerusalem, men han erobrer ikke byen. Ifølge 2 Kong 18,13-16 ophceves belejringen, fordi Hizkija vœelger at betale sig fra det. Anderledes fortcelles det i 2 Kong 19,35-37, hvor grunden til belejringens ophør er en pest, hvormed Jahve rammer den assyriske lejr. 185.000 mand dør af sygdommen, og Sankerib bryder op og vender hjem til Ninive.

At det ikke lykkedes Sankerib at erobre Jerusalem fremgår også af hans egen beskrivelse af felttoget, hvor han med mange detaljer beskriver, hvordan han erobrer den ene by efter den anden på vej mod Jerusalem. Alene 46 af judœeren Hizkijas stcrkt befœstede byer indeslutter han, og han tager stort bytte, både mennesker og kvaeg. Om Judas konge hedder det: "Jeg spcerrede ham selv inde i hans kongestad Jerusalem som en fugl i bur. Jeg anlagde faste vœrker mod ham og betog ham enhver lyst til at gå ud af hans bys port." Videre hedder det, at kong Hizkija blev overvœldet af frygt over at se hans herskerpersonlighed, og det beskrives omstcendeligt, hvor mange krigere og hvor stort et bytte af bl.a. sølv og guld, Sankerib kunne føre med sig hjem til Ninive. Men indirekte fremgår det, at Jerusalem ikke blev erobret, men slap med at betale en stor bod (jf. Sankeribs beretning om felttoget, som i dansk overscttelse er gengivet i Benedikt Otzen 1977, 335-336; se også det fyldigere uddrag af beretningen nedenfor s. 46-47).

\section{Faktaboks: Årstalsliste}

Juda

Uzzija 787-744

Jotam $744-736$

Akaz 736-715

Hizkija (Ezekias) 715-696
Nordriget (Israel; Efraim) Assyrien

Jeroboam II 787-747

Tiglat Pileser III 745-727

Zekarja 747

Sjallum 747

Salmanassar $\vee 726-722$

Menahem 747-738

Pekaja 737-736

Peka 735-732

Hosea 731-722

Nordrigets fald 722
Sargon II 721-705

Sankerib 704-681 
Jf. til årstalslisten Benedikt Otzen 1977. Israeliterne i Palcestina. Det gamle Israels historie, religion og litteratur. København: G.E.C. Gad, 264, 329-33.

Tilbage til indholdsfortegnelsen

\section{Den politiske udvikling fra 612 f.Kr. til 539 f.Kr.}

Da den sidste af de store assyriske konger, kong Assurbanipal, døde omkring 630 f.Kr., begyndte det store rige at falde fra hinanden. Babylonerne og mederne benyttede lejligheden til at gøre oprør mod assyrerne. I 612 f.Kr. falder den assyriske hovedstad Ninive, og i 605 f.Kr. taber assyrerne til babylonerne ved et stort slag ved Karkemish, en by tcet ved Eufratfloden. I Juda benyttede kong Josija assyrerrigets tilbagegang til at udvide sit eget område ved at inddrage dele af det gamle Nordrige under Juda. I 622 f.Kr. gennemfører han en større kultreform, der tydeligt viser, at det nu var muligt at agere selvstœndigt i Juda (jf. at kong Akaz som tak for assyrerkongens hjœlp under den syriskefraimitiske krig havde måttet lade bygge et alter i Jerusalem svarende til alteret i Damaskus, 2 Kong 16,10-18).

Kong Josijas tid som konge over Juda endte dog tragisk, idet han falder i slaget ved Megiddo 609 f.Kr., hvor egypterne standser hans forsøg på at udvide sit rige. Egypterne har på dette tidspunkt magten i Syrien og Palcestinaområdet; men inden lœenge kommer det til en afgørende magtkamp mellem dem og babylonerne. Da babylonerne har besejret assyrerne ved Karkemish i 605 f.Kr., kommer Juda under babylonsk overherredømme, men efter nogle år gør kongen i Juda, Jojakim, oprør mod babylonerne, hvis hersker er kong Nebukadnezar, 2 Kong 24, 1. I 598 f.Kr. belejrer babylonerne Jerusalem, og byen overgiver sig det følgende år, 597 f.Kr. Konsekvensen af oprøret bliver, som det var tilfœldet i forlœengelse af den syrisk-efraimitiske krig, at Jerusalem brandskattes og må aflevere store rigdomme fra paladset og templet. Desuden ivœrkscttes en første deportation af indbyggerne til Babylon, heriblandt den unge kong Jojakin, der netop havde afløst sin far.

For at sikre stabiliteten i Juda udncevner babylonerkongen en ny konge, Zedekias, der fungerer som babylonsk lydkonge. Også han vœlger at konspirere mod storkongen, hvorfor Jerusalem endnu engang bliver belejret af babylonerne. Efter $1 \frac{1}{2}$ år, hvor babylonerne har haerget de omliggende byer, bryder de gennem muren til Jerusalem, ødelœgger murene og nedbrœnder både kongepaladset og templet 587 f.kr. Også nu deporteres en del af indbyggerne til Babylon. Det babylonske eksil varede til 539 f.Kr., hvor perserkongen Kyros tog magten og gav tilladelse til, at de eksilerede jøder kunne vende hjem og genopbygge templet, Ezra 1. 
Faktaboks: Årstalsliste

Juda

Josias (Josija) 639-609

Joahaz 609

Jojakim 608-598

Jojakin 598-597

Zedekias 597-587

Juda Riges fald 587
Assyrien, Babylon og Perserriget

Assurbanipal 668-627 (assyrisk konge)

Nabopalassar 625-605 (nybabylonsk konge)

Ninives ødelceggelse 612

Nebukadnesar 605-562 (nybabylonsk konge)

Kyros 559-530 (perserkonge)

Kyros erobrer Babylon 539

Kyros giver tilladelse til, at de eksilerede vender tilbage til Jerusalem 539

\section{Templet fardigbygget 516}

Jf. til årstalslisten Benedikt Otzen 1977. Israeliterne i Palcestina. Det gamle /sraels historie, religion og litteratur. København: G.E.C. Gad, 264, 329-33 samt Gads Bibelleksikon, Bd. I, Kronologi, 441-442.

Nedbrœndingen af templet og bortførelsen af en del af befolkningen til Babylon udgør sammen med eksilet i Babylon baggrunden for store dele af Jesajabogen, ikke mindst Jes 40-55. Det er da også her man finder en direkte omtale af perserkongen Kyros, der skildres som Herrens salvede og dermed hans redskab til at besejre babylonerne, Jes 45,1-4. Lœser man videre i Jes 56, viser det sig, at de eksilerede nu er kommet tilbage til deres eget land, og at der findes et Guds hus, som skal bruges som bedehus, Jes 56,7. Templet er altså genopbygget, hvilket skete i årene frem til 516 (Se nœermere om den politiske situation i Miller \& Hayes 2006 samt Benedikt Otzen 1977; Niels Peter Lemche 1984, 133-163; se også Niels Peter Lemche 2008).

Oplysningerne i Jesajabogen om de politiske forhold viser, at der er tale om en tekstsamling, der indholdsmœessigt dœkker over en lœngere periode i Judas historie. Nogle af teksterne afspejler begivenheder, der kan dateres til anden halvdel af 8. årh. f.Kr. Andre tekster angår begivenheder, der har forbindelse med eksilet og hjemkomsten fra Babylon, og endelig er der endnu yngre tekster, der afspejler situationen efter tempelindvielsen. 


\section{Skrivekunsten og nedskrivningen af profetorakler}

At tekster beskceftiger sig med daterbare begivenheder betyder ikke nødvendigvis, at teksterne er prœcis samtidige med disse begivenheder. En forsker som Peter D. Miscall hœevder således, at Jes 139 er en eftereksilsk fremstilling og fortolkning af den føreksilske periode (Peter D., Miscall 2006, 19). Nedskrivningen kan ske på et langt senere tidspunkt og derfor bygge på mundtlige traditioner, som er blevet videregivet af profetens disciple eller af andre tilhcengere af profetens forkyndelse. Men uanset hvornår, så er den første forudsctning for nedskrivning af profetiske orakler naturligvis, at der på det pågœldende tidspunkt findes personer, der behersker skrivekunsten. Det œldste, kendte eksempel på en tidlig-hebraisk tekst er den såkaldte Gezerkalender fra anden halvdel af 10. årh. f.Kr. (se ncrmere i Gads Bibelleksikon), men derudover er der fx fundet mange beskrevne potteskår omkring Samaria og seglaftryk på lerkrukker i Juda fra 8. årh. f.Kr. På profeten Jesajas tid har der således vœret personer, der beherskede skrivekunsten.

Dette fremgår også af Jes 8,1, hvor profeten får besked fra Jahve om at tage en stor tavle og nedskrive ordene: Le-Maher-Shalal Hash-Baz. Vi hører intet om, at profeten vœgrer sig mod opfordringen, men heller intet om, hvorvidt han selv skriver, eller om han har en anden til at gøre det for sig. Men det fremgår af det følgende, at ordene på tavlen skal bruges som navn på den søn, profeten får. Meningen må vœre, at profeten ved sønnens fødsel skal kunne fremvise en tavle med netop disse ord som tegn på, at Jahve forud havde bestemt, hvad sønnen skulle hedde, og gennem dette navn forudsagt assyrerkongens erobring af Damaskus og Samaria. Opfordringen til at skrive indgår i profetens Denkschrift, Jes 6,1-9-6, der af en stor del af forskerne betragtes som hørende hjemme i 8. årh. f.Kr. På det tidspunkt gav det altså god mening at tale om nedskrivning af budskaber fra Jahve. Problemet er blot, at Denkschrift også giver god mening som forklaring på den katastrofe, som eksilet i 6. årh. f.Kr. var.

Hvad vi hidtil har ncevnt, drejer sig om ganske korte meddelelser. Men hvornår er man begyndt at nedskrive lœngere tekster? Og hvad er forudscetningen for en sådan aktivitet? Af de historiske bøger, Det Deuteronomistiske Historievœrk og Krønikebøgerne, fremgår det, at der har eksisteret forskellige kongelige krøniker (se fx 2 Kong 16,19 eller 2 Kong 20,20), hvor vigtige begivenheder i kongernes regeringstid er nedskrevet. Til at nedskrive og dermed fastholde vigtige oplysninger har 
der eksisteret professionelle skrivere. Statsskrivere omtales i Jes 36,3.22; 37,2 samt i 2 Sam 8,16-17; 20,23-26; 1 Kong 4,1-6 sammen med andre former for kongelige embedsmcend. Jesajabogens skildring af profeten viser, at han har en ncer tilknytning til templet og til kongen. Vi ved dog ikke, om det har medført, at fx nogle af de orakler, Jesaja har fremsat om den politiske situation, er blevet nedskrevet med henblik på de kongelige arkiver.

Også i profetkredse har der varet en interesse for at bevare profetens udsagn til senere tider. Dette fremgår fx af beretningen i Jer 36, hvor profeten Jeremias får befaling om at nedskrive alle de orakler, Jahve har sendt ham med mod Israel, Juda og alle folkene siden Josijas tid (Josija var konge i Juda i 639-609). Jeremias tilkalder sin skriver, der efter profetens diktat skriver det hele ned i en bogrulle. Formålet er at bevare ordene, så Baruk kan lœse dem højt for menigheden til skrœk og advarsel. Måske vil judœeerne så vende om fra deres onde veje og bede om Jahves tilgivelse. Oplœsningen finder sted på en scerlig fastedag i skriveren Shafans søn Gemarjas kammer i den $\varnothing v r e$ forgård. Blandt de tilstedevcerende er mange stormcend samt statsskriveren Elishama, hvilket netop viser, at der har eksisteret en scerlig funktion knyttet til tempel og konge som statsskriver. At kong Jojakim ikke ønsker at bevare profetens ord fremgår af beretningens videre forløb, hvor kongen lader bogrullen brœnde. Der gives ingen begrundelse for, at bogrullen skal brœndes. Men grunden kan meget vel vœre, at kongen frygtede, at den nedskrevne tekst var virkekraftig, så de ulykker, profeten forkyndte, også ville indtrœffe, hvis ikke ordene blev tilintetgjort. Derfor må Baruk endnu engang skrive det hele ned i en bogrulle, så Jahves ord kan bevares.

Et andet eksempel på omtale af skrivekunsten findes i Jes 37, hvor den judciske konge Hizkija modtager et brev fra assyrerkongen Sankerib og i vrede og fortvivlelse går ind i templet og viser brevet til Jahve med en klar opfordring til, at nu skal Jahve lytte til kongen og åbne øjnene, så han kan se, hvordan assyrerkongen spotter den levende Gud (se også Jer 29, hvor Jeremias sender et brev til de jøder, der er blevet ført til Babylon).

De nœvnte eksempler viser, at der var en professionel stand af skrivere, som kunne nedskrive vigtige begivenheder og budskaber. Med skriften kunne traditionen fastholdes uforandret for eftertiden. Men netop derfor var det også vigtigt at supplere de beretninger og orakler, der var nedfœeldet, med nyere stof, der kunne uddybe, kommentere eller videreføre den forkyndelse, som fx tog sit udgangspunkt i profeten Jesaja. Ved hjœlp af sådanne videreførelser af forkyndelsen kunne tilhœngerne understrege aktualiteten i profetens ord. Et eksempel på en sådan kommentering er Jes 7,8, hvor ordene, "Femogtres år endnu, så er Efraim knust og ikke løengere et folk", afbryder den 
fremadskridende argumentation og den poetiske form med en tidsmcessig prceisering (se ncermere i kommentaren til dette vers).

Noget tilsvarende kan man se i Jes 8,6-7, hvor den poetiske stil afbrydes med to praciserende kommentarer om de konger, der truede Juda, "Resin og Remaljas søn", v. 6, og "assyrerkongen i al hans vœlde", v. 7. I den danske overscettelse fra 1992 er der sat tankestreger omkring de to udsagn for at markere, at de skal forstås som tilføjelser. I den hebraiske tekst er der ingen markering af denne art, men i det tekstkritiske apparat foreslås de slettet, dog uden belœg i form af andre hebraiske manuskripter eller de gamle overscettelser. Oraklet hører hjemme i forbindelse med den syriskefraimitiske krig, og på den tid var ingen i tvivl om, at grunden til, at folket havde mistet modet, var truslerne fra aramcerkongen Resin og Nordrigets kong Peka, Remaljas søn. Men på et senere tidspunkt blev det nødvendigt at tilføje en sådan realkommentar, så det blev klart, hvem der var tœenkt på. Det samme galder indføjelsen af "assyrerkongen i al hans vœlde". Hvornår disse tilføjelser er kommet ind i teksten, og hvem der står bag dem, ved vi ikke. Men den pågaldende har uden tvivl ment, at hans fortolkning var en sand udlcegning af Jesajas ord.

Det fremgår af Jes 8,16-18, at profeten på et tidspunkt "binder til for budskabet" og "forsegler belœringen hos mine disciple”. Nogle forskere har tolket dette billedlige udtryk som en befaling om for en tid at lade ordene blive under segl, dvs. i en skriftrulle. I så fald har der blandt profetens disciple vœret skrivekyndige, som har nedskrevet det budskab, Jesaja fremsatte i forbindelse med den syrisk-efraimitiske krig, Jes 8,1. En anden og mere sandsynlig mulighed er, at der er tale om et billedligt udtryk, der betyder, at nu skal Jesajas disciple tie (se ncermere i kommentardelen til Jes 6,5). Til gengœld for det talte ord skal Jesaja selv og børnene fungere som tegn.

\section{Tilbage til indholdsfortegnelsen}

\section{Fortolkning, videreførelse og nedskrivning af Jesajas forkyndelse}

Vi ved ikke, hvor tidligt man er begyndt at nedskrive beretninger og ord af profeten Jesaja.

En stor del af stoffet i Jes 1-39 kan meget vel gå tilbage til 8. årh.f.Kr. Noget er udtalt af profeten selv, andet er hans disciples videreførelse af budskabet, og det er ofte vanskeligt at afgøre, hvad der er hvad. Når jeg omtaler den jesajanske forkyndelse som Jesajas forkyndelse, er det derfor ikke den historiske person Jesaja, jeg tcenker på, men den forkyndelse, der er gengivet i Jes 1-39, Protojesaja. Forskerne forsøger naturligvis at bestemme, hvilke orakler i Jes 1-39 der går tilbage til den periode, 
hvor den historiske profet virkede, men hvornår selve nedskrivningen har fundet sted er ikke dermed afgjort.

\section{Faktaboks}

Et af de klassiske forsøg på en datering er foretaget af den tyske gammeltestamentler Hans Wildberger (se Hans Wildberger 1984, 46-60). Mens nyere forskning er tilbageholdende med at skelne mellem orakler, der går tilbage til profeten selv, og senere tilføjelser, mener Wildberger, at forsøget bør gøres, og at man som kriterier både kan bruge de begivenheder, der omtales, og den scerlige jesajanske sprogtone. Herudfra når Wildberger frem til, at størstedelen af Jes 1-12 går tilbage til profeten Jesaja og hans tid, og at det gennemgående princip for placeringen af orakler og fortcellinger har vœret den kronologiske rœkkefølge. Wildberger opererer med følgende faser i Jesajas forkyndelse.

1) Jesajas tidlige forkyndelse, fra kaldelsen og frem til den syrisk-efraimitiske krig, findes i Jes 2,64,$1 ; 5,1-7 ; 5,8-24 ; 10,1-3$. Fœlles for disse afsnit er kritikken af interne forhold i landet.

2) Størstedelen af Denkschrift, nemlig Jes 7,1-8,18, hører hjemme i forbindelse med den syriskefraimitiske krig (732-34 f.Kr.). Kaldelsesberetningen går ligeledes tilbage til Jesaja og er blevet placeret foran Denkschrift for at understrege, at manglende lydhørhed får katastrofale følger.

3) Udsagn fra tiåret op til Nordrigets fald 722 f.Kr. findes i Jes 5,25.26-29; 9,7-20, der omhandler Jahves vrede mod Nordriget.

4) Udsagn fra Sargon II's tid (721-705 f.Kr.) findes i Jes 10,1-3(4); 10,5-9.13-15a; 10,27b-34; 11,19.

5) Jes 1,2-2,4(5) betragter Wildberger også som jesajansk (Jes 1,10-17.18-20.21-26 og formentlig Jes 1,29-31 hører til den tidligste fase), men han behandler dem for sig, da de har fået en scerlig funktion som prolog til den jesajanske forkyndelse.

Også senere kommentatorer som Gerald T. Sheppard mener, at redaktorerne har forsøgt at placere traditionerne i kronologisk orden ud fra de vigtigste historiske begivenheder på Jesajas tid (Gerald T. Sheppard 1988, 547-48). Sheppard er dog mere tilbageholdende med prœcise dateringer af enkeltorakler og opdeler blot Jes 1-12 i Jes 2,6-5,7, som tilhører den tidligste fase med dom over lederne, og fortcllestoffet i Jes 6,1-9,6, som angår begivenhederne omkring den syrisk-efraimitiske krig, 735-33 f.Kr. Den nœeste afgørende begivenhed er det filistceiske oprør mod assyrerne i 713-711 f.Kr. Som nedslag heraf nœevner Sheppard Jes 20,1-6. Og endelig er begivenhederne omkring belejringen af Jerusalem under Sankerib, 701 f.Kr., beskrevet i Jes 36-38 (jf. Jes 1,8, hvor skildringen af Zions datter som en hytte i vingården netop kan tolkes ud fra Jerusalems belejring i 701 f.Kr.)

Ikke mindst de politiske kriser, som ramte landet på Jesajas tid, har givet anledning til profetisk aktivitet. Vigtige dele af den tidlige Jesajatradition samler sig da også om to afgørende begivenheder: den syrisk-efraimitiske krig og Sankeribs belejring af Jerusalem. Men når udsagnene er blevet bevaret ud over urolighederne i 734-32 og 701 f.Kr., så skyldes det, at ødelœggelsen af Samaria i 722 f.Kr. 
og indlemmelsen af Nordriget i assyrerriget er blevet tolket som tegn på, at profetens forkyndelse stod til troende, og at truslen fra assyrerne derfor stadig var en realitet - ganske vist ikke lcengere for Nordriget, men for Juda.

Med assyrerrigets tiltagende svaghed (Ninive falder i 612 f.Kr. for babylonerne) synes det dog for en tid at se mere lyst ud (jf. kong Josijas regeringsperiode, der i Det Gamle Testamente fremstår som en god tid med en Jahvetro konge). Men kun for en tid. Efter assyrerne bliver babylonerne de nye magthavere i området og dermed en aktuel trussel for Juda. Orakler, der taler om assyrerne som Jahves middel til at straffe sit ulydige folk, giver derfor stadig mening og kan genbruges, nu blot tolket om babylonerne. Nogle forskere vil således tolke den spottende skildring i Jes 14,19-20 af den drœbte konge, hvis lig ligger henslœengt på jorden, som en beskrivelse af assyrerkongen Sargon II, hvis lig blev efterladt på slagmarken efter et slag. I sin nuvœrende form er spottesangen dog rettet mod babylonerne, Jes 14,4; men den efterfølges af et domsorakel mod assyrerne, Jes 14,24-27, hvilket kunne underbygge forslaget om, at det oprindelig var assyrerkongen, der var tcenkt på.

For redaktorerne har Jesajas ord i de politiske krisesituationer stadig haft gyldighed og derfor vœret vœerd at bevare i skriftlig form. Det samme gœelder anklagerne mod lederne for undertrykkelse af de svage i samfundet. Uanset om disse anklager oprindelig har vœret udtalt i én bestemt situation, så mister de ikke deres aktualitet. Hvad der står at lœse i fx Jes 1,16-17 om at tage vare på de svage i samfundet, kunne med god grund gentages efter Jesajas tid, også i det samfund, der skulle bygges op efter hjemkomsten fra Babylon.

Behovet for at bevare og viderefortolke den oprindelige forkyndelse er blevet forstcrket op gennem Judas historie. Navnet Jesaja betyder Jahve frelser. Centrale dele af Jesajas forkyndelse lever da også op til navnet. Jahve ønsker at redde sit folk. At Sankerib opgav sin belejring af Jerusalem i 701 f.Kr. er blevet tolket som udtryk for, at Jahve greb aktivt ind for sit folks skyld, Jes 37,21-38. Men med ødelœggelsen af Jerusalem i 587 f.Kr. og bortførelsen af en del af folket til Babylon var det ikke nok at mindes Jesajas ord om en frelsende Gud. Også hans forkyndelse af en hellig og retfcerdig Gud, der måtte straffe sit ulydige folk, så kun en rest blev tilbage, måtte fastholdes. Den Zionteologi, som forkyndte Jerusalems uindtagelighed og Jahves hjcelp mod fjenderne, SI 46 og 48, havde vist sine begrœnsninger. Også kongeideologien med løfterne om, at der altid skulle sidde en konge på Davids trone i Jerusalem, måtte forstås i lyset af de politiske begivenheder. De aktuelle konger havde ikke altid levet op til forventningerne, derfor måtte også de bøde for deres manglende tillid til 
Jahve. Også i den sammenhceng var den jesajanske domsforkyndelse relevant som forklaringsmodel. For her mødte man ikke blot løfterne om en lys fremtid, men også profetier om den nødvendige straf for folkets synd.

Den anden store del af Jesajabogen, Jes 40-55, bœrer prœg af de erfaringer, som kommer til udtryk i Jes 1-39. I denne anden del, Deuterojesaja, møder vi en forkyndelse, der tager udgangspunkt i, at den nødvendige straf harfundet sted. Jerusalems skyld er betalt, ja byen og dens befolkning har fået "dobbelt straf for alle sine synder", Jes 40,2. At Jahve nu vil vise sin barmhjertighed og føre sit folk tilbage forkynder Deuterojesaja i kap. 40, og gennem de følgende kapitler understreges det igen og igen, at det er Jahve og ingen anden guddom, der har magt til at styre historiens gang.

Ned gennem denne del af Jesajabogen argumenteres der for såvel Jahves barmhjertighed som for hans magt. Men Jes 40-55 giver kun mening, hvis man lœeser Jes 1-39 som begrundelse for, at det overhovedet er kommet dertil, at der bor jøder i eksil i Babylon. Disse kapitler giver ikke blot en beskrivelse af, at sådan gik det, men udgør bevisførelsen for, at ødelceggelsen af Jerusalem og eksileringen var en konsekvens af folkets synd og dermed Jahves retfœrdige straf. Det er derfor sandsynligt, at den egentlige redigering af Jes 1-39 først har fundet sted i forbindelse med det babylonske eksil og hjemkomsten derfra. ${ }^{8}$

Tilbage til indholdsfortegnelsen

\section{De politiske grundvilkår og opfattelsen af Jahve som baggrund for genbrug af profetiske orakler}

Når den profetiske forkyndelse har egnet sig til genbrug i senere tider, er en af grundene naturligvis, at Nœrorientens historie er prœget af nogle grundlœeggende vilkår, som igen og igen skaber kriser i det palœstinensiske område. Palœstina ligger som gennemgangsområde for de vigtige handelsruter mellem Egypten, Lilleasien og Mesopotamien. Det er derfor politisk afgørende at have magten over dette område. Gennem århundreder har nabolandene og stormagterne ønsket at kontrollere netop dette område, hvorfor beboerne i det palœstinensiske område hyppigt har vœret udsat for angreb udefra og i perioder har måttet underkaste sig fremmede magter. Trusler udefra og fremmedherredømme var politiske realiteter, men de var, set med datidens øjne, mere end det. De var udtryk for deres egen Guds indgriben i historien.

\footnotetext{
${ }^{8}$ Til diskussionen om, hvad der er historisk i profetlitteraturen, og hvad der er littercer "konstruktion", henvises til Jesper Høgenhaven 1999.
} 
I Jesajabogen tolkes den syrisk-efraimitiske krig, Sankeribs erobring af dele af Juda og belejringen af Jerusalem samt babylonernes erobring af Jerusalem og det efterfølgende eksil som led $\mathrm{i}$ Jahves planer for sit folk. Ikke mindst i den deuterojesajanske forkyndelse, Jes $40-55$, bliver det tydeligt, at det alene er Jahve, der beslutter, hvad der skal ske i denne verden. De andre folkeslags guder er ude af stand til at handle. I Jes 41,21-29 indkalder Jahve de fremmede guder til en retssag for at få afgjort, hvem der står bag perserkongen Kyros' sejr over babylonerne. Og udfaldet er klart: De fremmede guder kan intet udrette, de kan hverken forudsige noget eller gøre noget. Det er Jahve selv, der har kaldt på "ham fra norden", Jes 41,25, og derfor også Jahve, der kan få Kyros til at genopbygge Jerusalem og grundløegge templet, Jes 44,28 (se også Jes 41,1-5 samt 45,1, hvor Jahve kalder Kyros for sin salvede).

Når det er Jahve, der har al magten, så vil ord fra Jahve i én situation også vœre aktuelle i tilsvarende senere situationer. For centrale dele af gudsopfattelsen forbliver stabile ned gennem Jesajabogen: Jahve har udvalgt sig sit eget folk, og deres indbyrdes forhold bygger på gensidig loyalitet. Som $\mathrm{i}$ et forhold mellem en far og hans børn, Jes 1,2, skal folket holde sig til Jahve alene og adlyde ham, til gengald vil Jahve tage sig af sit folk. Men glemmer folket sine forpligtelser over for Jahve, vil Jahve gribe ind og straffe dem. Og et af midlerne hertil er folkets fjender, som Jahve for en tid kan bruge som strafferedskab, hvad enten det er assyrerne eller babylonerne. Men også positivt kan Jahve bruge fremmede konger, som da perserkongen Kyros greb ind og befriede jøderne fra det babylonske fangenskab. For da var straffen "fra Herrens hånd" forbi, og folket kunne vende hjem til Zion, Jes 40,1-11.

Tilbage til indholdsfortegnelsen

\section{Den profetiske forkyndelse som fremsigelse og forudsigelse}

Profetisk forkyndelse er oprindelig mundtlig forkyndelse. Profeterne har talt på Jahves vegne, så de ledende og folket har kunnet få indblik i Jahves vilje og rette sig derefter. På forskellige måder markeres det derfor i forkyndelsen, at det ikke er profetens egne ord, men Jahves ord, han taler. Ved sin kaldelse får profeten Jeremias Jahves ord lagt i sin mund, Jer 1,9, ligesom Ezekiel må sluge en hel bogrulle med de ord, Jahve sender ham med, Ez 3,1-3. Ganske som en konge sender sit sendebud for at videregive kongens befaling og ikke sine egne tanker, skal profeten referere, hvad han har fået overdraget af Jahve (jf. Jer 23,18, der viser, at den sande profet er til stede i Jahves rådsforsamling og derigennem får kendskab til Jahves vilje). En del profetiske orakler vil derfor vaere indledt med 
den såkaldte sendebudsformel, כה אמר יהוה, "Dette siger Herren" eller varianter af denne type, fx Jes 7,7 .

En profet er en, der fremsiger Jahves ord til modtagelse eller til afvisning. Profeterne taler ind i aktuelle situationer til deres egen samtid, både når de forkynder Jahves straf, og når de lover fred. Orakler, der indeholder trusler om en kommende straf, kaldes domsorakler. At straffen endnu ikke er realiseret, kan betyde, at der stadig er håb for dem, der vender om til Jahve, dvs. den rest, som profeten flere gange vender tilbage til i Jes 1-12. I andre sammenhœnge vil vœegten ligge på, at det er Jahve, der står bag truslen, og at den derfor er uafvendelig. Dette gcelder fx domsoraklerne mod de fremmede folkeslag, som dermed indirekte bliver til frelsesorakler for folket selv.

Eftertiden har dog ikke nøjedes med at se profeterne som aktuelle forkyndere i fortiden, men har forstået deres budskaber som udsagn om fremtiden, den nœere eller den fjernere. Så lœnge freden endnu ikke er en realitet, må håbet om freden holdes i live og forventningerne rettes mod fremtiden. Og at kun Nordriget var gået til grunde under assyrerne og Jerusalem blevet skånet, betød ikke, at Jahves trusler mod sit eget folk blev glemt.

Da babylonerne kom til magten og ganske som assyrerne ønskede at udvide deres magtsfcere, var det ikke blot den politiske historie, der så ud til at gentage sig. Jesajaoraklerne fra 8. årh. f.Kr. måtte også gentages, for alt tydede på, at de endnu engang ville vœre sande udtryk for Jahves vilje. Ganske som folket var blevet straffet med assyrernes angreb og ødeløggelser i 8. årh., ville babylonerne nu optrcede som Jahves straf over folkets synd. Men ligesom Jahve greb ind i 701 f.Kr. og frelste Jerusalem, således måtte man endnu håbe, at han ville gribe ind og frelse sit folk fra babylonerne. Ikke nødvendigvis på helt samme måde, men dog således at en rest ville vende tilbage. På den måde kunne datidens fremsigelser blive tolket som forudsigelser af den nu aktuelle situation.

Men tolkningen af den jesajanske frelsesforkyndelse som forudsigelse fik et alvorligt kncek, da Jerusalem blev erobret i 587 f.Kr. Jerusalem var ikke uindtagelig, sådan som man havde sunget om i Zionhymnerne (jf. folkekampmyten). Jerusalem blev ikke skånet, og byen blev ikke centrum for alle folkeslagene, sådan som man havde kunnet håbe på ud fra den jesajanske forkyndelse, Jes 1,8 samt 2,2-5. At håbet overhovedet kunne overleve, så det gav mening at bevare den protojesajanske forkyndelse, hang først og fremmest sammen med, at man var overbevist om, at det var Jahve selv, der havde udleveret sin by til fjenderne. Derfor var det ham, der straffede sit eget folk, og det var også ham, der straffede de fremmede folkeslag. 
I Jes 13-23 findes en stor samling domsorakler vendt mod alle folkets fjender: babylonerne, assyrerne, filistrene, moabitterne, Damaskus og Efraim, egypterne samt Tyrus og Sidon. At det skulle gå ens fjender ilde har skullet give anledning til et vist håb for fremtiden, selv om der midt i oraklerne mod de fremmede står et domsorakel mod Jerusalem, Jes 22. Jahve vil behandle sine egne, som var de blevet fremmede for ham. Men hvad der kun indirekte gav anledning til håb i form af fjendernes nederlag, det udtrykkes direkte i de følgende orakler om folkets frelse, Jes 24-27.

Denne dobbelthed, at Jahve både ville straffe og frelse en del af sit udvalgte folk, kendetegner Jesajabogens forkyndelse og har gjort den så velegnet som fortolkning af de politiske begivenheder ikke blot i 8. årh. f.Kr., men også derefter.

Tilbage til indholdsfortegnelsen

\section{KAPITEL 4}

\section{Jes 1,1-2,5}

Før man begynder analysen af en gammeltestamentlig tekst, er det vigtigt at overveje, om teksten er forståelig i den overleverede form, eller om det er nødvendigt at rette teksten. Den tekst, der ligger til grund for standardudgaven, Biblia Hebraica Stuttgartensia, er Codex Leningradiensis, der stammer fra omkring år 1000 e.Kr. At netop dette kildeskrift er valgt som standard skyldes, at det er det œldste fuldstcendige manuskript til Gammel Testamente og desuden er af god kvalitet. Dette betyder dog ikke, at denne tekst til enhver tid skal vœlges frem for andre. Her må hvert enkelt sted vurderes for sig med inddragelse af det tekstkritiske apparats forslag (se nœrmere om de rettelser, der ligger til grund for DO 1992, i Svend Holm-Nielsen, Noter til bibeloverscettelsen af 1992. Rettelser i den hebraiske tekst. Det danske Bibelselskab, København 1997).

\section{Tekstkritik}

$7 a$

MT: fremmedes. Rettelsesforslag BHSa: Sodomas. Der er ingen tekstvidner, men ordet מהפכה står ellers altid sammen med bynavnet Sodoma i GT, jf. Deut 29,22; Jes 13,19; Jer 49,18; Jer 50,40; Am 4,11. Når afskriveren skriver fremmede, kan det skyldes, at ordet forekommer tidligere i verset. DO 1992 
følger rettelsesforslaget. Bevares MT, betyder teksten: "en ørken som fremmedes ødelœggelse", hvilket ikke giver så god mening i sammenhœengen.

\section{$27 a$}

MT: dens tilbagevendte eller dens omvendte. Rettelsesforslag BHSa: dens indbyggere. Der er ingen tekstvidner til denne rettelse, der dog følges af DO 1992. På hebraisk er der kun et enkelt bogstav til forskel mellem de to løesemåder. Rettelsen er sandsynlig, men ikke nødvendig.

\section{$29 a$}

MT: skam skal de få. Rettelsesforslag i BHSa: skam skal I få. Nogle få hebraiske manuskripter har den foreslåede form (2. pers. plur.). Rettelsen følges af DO 1992. Se dog ncrmere i kommentaren til stedet.

\section{2,2-4}

Disse vers findes i ncesten ordret form i Mi 4,1-3. Nogle forskere foreslår derfor, at Jes 2,2-4 rettes til i forhold til Mi 4, 1-3. Dette ville dog forudscette, at Mikateksten er den œldste, og at Jesajaversionen er tœnkt som en direkte gengivelse deraf. Da vi ikke ved, om dette er tilfcldet, er der ikke tilstrckkelig grund til at rette i en fuldt ud forståelig tekst.

\section{Karakteristik}

Efter en indledende tidsfœestelse af de syner, profeten Jesaja modtog i anden halvdel af det 8. årh. f.Kr., følger en rœkke enkeltorakler. Disse orakler fungerer som en programmatisk indledning til Jesajabogen og indeholder de afgørende temaer i Jes 1-39, Protojesaja: folkets synd, v. 2-3, Jahves dom, v. 4-9, den falske gudsdyrkelse og uretfardige behandling af de svage, v. 10-17, muligheden for redning, v. 18-20, renselsen af Jerusalem, v. 21-28, fordømmelse af tilliden til de fremmede magter $\mathrm{i}$ billedet af stcrke trœer, v. 29-31, samt Zions ophøjelse og det kommende fredsrige, Jes 2,1-5.

De enkelte orakler tilhører forskellige genrer, Gattungen, men angiver tilsammen et handlingsforløb, der er karakteristisk for den jesajanske forkyndelse. Med anråbelsen af himmel og jord som vidner indledes en retsscene, hvor folket anklages for at have svigtet Jahve, Jes 1,2-3. Konsekvensen er, set ud fra rettergangsbilledet, at Jahve må fœlde dom over sine ulydige børn. Dommen 
har form af et veråb, der afrundes med en erkendelse af, at Jahve trods alt har skånet en rest, Jes 1,4-9.

Kapitlet fortscetter i den kritiske tone med en prœcisering af anklagerne i form af kultkritik og etisk kritik, Jes 1,10-17. Med v. 18-20 genoptages rettergangsbilledet med en understregning af, at folkets egne handlinger er afgørende for, om de vil få et godt liv i deres eget land, dvs. blive frikendt, eller de vil blive drœbt af svœrdet, dvs. kendt skyldige.

Jes 1,21-28 har form af en klage, hvor den lykkelige fortid scettes op i modscetning til den sørgelige nutid. Indirekte fortscettes dermed anklagerne mod folket, fordi de har handlet uetisk. Konsekvensen af den manglende retfcerdighed formuleres derpå i et veråb. Men trods den negative tone åbnes der for en positiv fremtid, idet Jahves straf tager form af en renselse, hvor de uretfœerdige fjernes, så den gode tilstand i fortiden kan genoprettes.

Kapitlets sidste orakel, Jes 1,29-31, fungerer som en dom over dem, der har sat deres lid til haver og trœer. Dette kan tolkes som udtryk for afgudsdyrkelse eller som et billedligt udtryk for de udenrigspolitiske forbindelser, som Jesaja også senere i Jes 1-12 vender sig kraftigt imod. Uanset fortolkningen taler Jes 1,29-31 om den totale udslettelse af dem, der har svigtet Jahve.

I kontrast hertil står Jes 2,1-5, der er et frelsesorakel. Det er som sådan afslutningen på den programmatiske indledning til Jes 1-39. Oraklet forkynder, hvilken fremtid Jahve planlœgger for Zion efter den retfcrdige afstraffelse af de uretfcerdige: Zion skal blive samlingspunkt for alle verdens folk, der vil lade sig belœre om Jahves vilje og fremover leve i indbyrdes fred. Med vers 5 formuleres en opfordring til at adlyde Jahve ved at vandre i hans lys. De, der lytter til Jesajas forkyndelse, skal forstå, at deres fremtid afhcenger af, om de adlyder Jahve eller ej. Det er i dette orakel det sidste af de vasentlige temaer i Jesajas forkyndelse prasenteres: Zions herlige fremtid som verdens centrum (se ncermere om Jerusalem og Zionideologien i Benedikt Otzen 1986). Den jesajanske forkyndelse i de første 12 kapitler er stcerkt prœget af anklage og dom. Men side om side med forestillingen om den nødvendige straf over folket p.g.a. dets frafald fra Jahve står løfterne om en fremtid for en del af folket. Et vigtigt element heri er det positive forhold til andre folkeslag. Hermed markeres en helt anden holdning end den, der kommer til udtryk mange andre steder, dels i Jes $1-12$ dels i Jes 13-27.

Kompositionen af Jes 1,1-2,5 minder om et musikstykke, hvor forskellige temaer gennemspilles flere gange og i varieret form. Gentagelsen af temaerne skal bidrage til, at tilhørerne/løeserne forstår og husker, hvor afgørende et budskab profeten er sendt med. 
Enkeltoraklernes Sitz im Leben er vanskelig at afgøre. Kultpolemikken i Jes 1,10-17 kunne fx vœre fremsat i forbindelse med en religiøs fest, hvor profeten anklager kultdeltagerne for at mene, at selve deltagelsen i kulten er tilstrckkelig, og ikke forstår, at Jahve er imod kult uden etik (se også polemikken i SI 50). Om de øvrige orakler gœelder, at de kan vœre fremsat hvor som helst, profeten har haft lejlighed til at få sine landsmand og deres ledere i tale, men Zions centrale rolle peger naturligvis på Jerusalem som stedet, hvor profeten har haft sit virke.

I den redigerede form, hvor oraklerne er anbragt som programmatisk indledning, har de fået deres scerlige Sitz im Korpus. De skal prcesentere de afgørende temaer i Jesajas forkyndelse med hovedvagt på folkets ulydighed mod Jahve, men dog med et håb om en positiv fremtid for en rest. Når Jesajabogen i modsctning til de to andre store profetbøger, Jeremiasbogen og Ezekiels Bog, ikke fortcller om kaldelsen af profeten i bogens begyndelse, men om hans forkyndelse, skyldes det redaktorernes ønske om at understrege, at den scrlige opgave, Jesaja blev sendt med, havde sin baggrund i folkets frafald. At profetens forkyndelse skulle føre til folkets forhcrdelse, Jes 6,9-10, er således en konsekvens af folkets manglende lydighed mod Jahve.

\section{Struktur}

Jes 1

1 Overskrift.

2-3 Retstale vendt mod det troløse folk.

4-9 Veråb over det syndige folk, hvoraf kun Zion er tilbage efter Jahves straf.

10-17 Kultkritik og etisk kritik.

18-20 Opfordring til rettergang.

21-28 Anklage for troløshed efterfulgt af domstale og løfte om nye tider efter renselsen.

29-31 Domstale på grund af folkets tillid til "trœerne".

Jes 2

1 Overskrift.

2-4 Forjœttelse om Zions ophøjelse.

5 Opfordring til at adlyde Jahve. 


\section{Fortolkning}

Kapitel 1

1

Kapitlet begynder med en overskrift, der betegner Jesajas forkyndelse som et syn. At profeter modtager syner, betyder ikke, at der er tale om ordløse åbenbaringer, men at det er Jahve, der har henvendt sig til profeten. Det følgende skal derfor ikke opfattes som profetens egne meninger om de aktuelle forhold, men som Jahves ord. Dateringen til den forholdsvis lange periode under fire kendte konger i Juda giver bedst mening, hvis denne overskrift er tœenkt som dœekkende de orakler, der er gengivet i Protojesaja, Jes 1-39. Uzzija regerede i Juda i årene 787-744 f.Kr.; Jotam regerede i 744736 f.Kr.; Akaz i 736-715 f.Kr. og Hizkija i 715-696 f.Kr. Der er tale om en vigtig politisk periode, der dœekker afgørende begivenheder som den syrisk-efraimitiske krig, 734-732 f.Kr., og Sankeribs belejring af Jerusalem i 701 f.Kr.. Overskriften har som funktion at forbinde den profetiske forkyndelse med et bestemt sted og en bestemt tid. Navnet på profeten, Jesaja, betyder Jahve frelser. Som overskrift kan profetens navn signalere det egentlige mål for forkyndelsen (se nœrmere i kommentaren til Jes $12 \mathrm{~s} .187)$.

\section{2-3}

Oraklet er indledningen til en profetisk retstale (se ncermere ovenfor s. 16-17). Det er Jahve, der indkalder himmel og jord. Som vidner kan de bevidne sandheden i den følgende anklage mod folket. Da sagen står mellem Jahve og hans folk, må vidnerne vœre i stand til at overskue alt, hvad sagen drejer sig om. Når hele universet fungerer som vidne, kan intet holdes skjult. At indkalde himmel og jord som vidner kendes fra de internationale pagtstraktater, hvor en storkonge indgår pagt med sine vasaller og kalder jord og himmel til vidne. Disse indkaldes tilsvarende, hvis vasallen bryder pagten med sin herre, og scettes under anklage for pagtsbrud. Det billede, der tegnes af Jahve, minder dermed om billedet af en storkonge.

Straks efter anvendes dog et andet billede: en far og hans børn (sønner). At vœre far indebar i datiden at have ansvar for og myndighed over børnene (se ovenfor s. 17-18). At Jahve har levet op til sit ansvar fremgår af de verber, der anvendes i v. 2: Jahve har opfostret dem, verbet גדל, dvs. sørget for deres daglige fornødenheder, så de har kunnet vokse sig store. Parallelt hermed siges det, at han har opdraget dem, verbet רום. Det hebraiske verbum dcekker formentlig mere end blot at få 
dem til at vokse i fysisk forstand. Lœest i konteksten må det dreje sig om, at han har indført dem i, hvad der forventes af dem som børn (jf. at de i vers 3 anklages for manglende forståelse).

Udgangspunktet for Jahves anklage er således, at han selv har opfyldt de forpligtelser, der hører med til at vœere far. Børnene, Judas folk, har til gengœeld ikke opfyldt deres forpligtelse. I stedet for at holde sig til deres far, har de brudt med ham. Det hebraiske verbum, ששע, betegner i den politiske verden at begå pagtsbrud, fx 1 Kong 12,19. Terminologien giver således associationer både til den politiske verden, hvor Jahve kan sammenlignes med en storkonge, og familiesfaren, hvor Jahve er husets overhoved som far. Begge roller indebcerer ncere bånd og forpligtelser mellem Jahve og hans folk.

Til at understrege det ncesten naturstridige i folkets opførsel anvendes et nyt billede, som er hentet fra dyreverdenen. Det er en almindelig erfaring, at selv et dyr ved, hvor det hører til, nemlig dér hvor det får sit foder. Oksen kender sin ejer. Glosen קנה kan både betyde at erhverve som ejendom og at skabe. Der kan således ligge en antydning af, at oksen ikke blot kender sin jordiske ejer, men - og i så fald for at gøre folkets forhold til dets Gud endnu mere grelt - også sin skaber. Parallelt hermed anvendes glosen for Herre, der kendes som gudenavn i Ugarit, Ba'al, men ikke nødvendigvis har de samme konnotationer her. At kende Gud, verbet ידע, betyder ikke blot at have viden om, men en indsigt, der fører til accept af, hvem Gud er, og hvad Gud krœver, fx Hos 4,6. Verbet בין, har samme indhold, jf. fx Job 28,28. I modscetning til dyrene mangler Israel, Jahves egne børn, denne indsigt og anerkendelse af ham som deres far. Navnet Israel betegner i denne sammenhaeng ikke Nordriget. Israel kan også bruges til at betegne Jahves folk, uanset om det er Nordriget eller, som her, Juda, der tœenkes på.

\section{Faktaboks: Okse og cesel}

Omtalen af okse og œsel, der kender deres herres krybbe, har haft en scrlig virkningshistorie. Hverken i Juleevangeliet, Luk 2, eller andre steder i Det Nye Testamente ncevnes oksen og ceslet. Men i en af de nytestamentlige apokryfer, Det Ucegte Matthceusevangelium fra 9. årh. e.Kr., citeres Jes 1,3: "Men på tredjedagen efter Herrens fødsel forlod Maria hulen, gik ind i en stald og lagde barnet i en krybbe; og en okse og et cesel tilbad ham. Da gik det ord i opfyldelse, som er talt ved profeten Esajas, som siger: 'Oksen kender sin herre, og œslet sin herres krybbe'." (kap. 14). Denne tolkning af Jes 1,3 genfindes i julekrybbetraditionen, hvor der står en okse og et œesel ved Jesu krybbe, og dermed indirekte retter anklage mod dem, der ikke tog imod Jesus som deres frelser. Valget af netop okse og œsel indebœrer muligvis også, at det er to meget forskellige dyr, der kender deres herre (jf. for- 
buddet mod at spœende okse og œsel for samme plov, Deut 22,10). Alle forskelle til trods mødes de netop ved Jesu krybbe (Kirsten Nielsen 2004, 31 -34).

Med v. 2-3 indledes retstalen mod de frafaldne børn. Efter anklagen ville man forvente, at der kom dels et forsvar dels en kendelse, hvor de anklagede enten frikendes eller dømmes. Det er dog karakteristisk for de profetiske retstaler, at der ikke er eksempler på, at folket får mulighed for at fremlœege et forsvar. Dette må tolkes sådan, at de intet har at sige til deres forsvar. Tilbage er derfor kun kendelsen. Vi ved ikke, om der, da oraklet blev fremsat første gang, fulgte en kendelse med, eller om profeten overlod det til tilhørerne selv at drage den ubehagelige slutning af sagens stilling. For ingen kan vare i tvivl om ud fra billedbrugen i v. 2-3, at det må ende negativt for de ulydige børn.

\section{4-9}

I den nuvœrende kontekst følger der ikke en kendelse i form af et domsorakel, men et veråb. Dette kunne tyde på, at v. 2-3 og v. 4-9 først på redaktionstidspunktet er blevet sat side om side. Et veråb hører genremœssigt ikke hjemme sammen med en anklage. Men med den nuvœrende placering får det samme funktion som en negativ kendelse.

Veråb anvendes som udtryk for vrede og sorg. Veråbet indebcerer en trussel om ulykke og anvendes også i forbindelse med dødsfald, hvor ulykken allerede er indtruffet, dvs. som led i en dødsklage. Dette er med til at give oraklet et uheldssvangert prœg. Folket er på det nœrmeste dødt. I oraklet karakteriseres folket som mennesker, der er syndige og fulde af skyld. Hvad de mere prcecist har gjort, fremgår af de følgende udsagn. Deres forbryderiske adfœrd indebœerer formentlig, at de bryder de gœidende samfundsregler, optrœeder som voldsmcend og på forskellig vis forbryder sig mod andre mennesker. At de bringer fordcerv er et motiv, som kendes fra Gen 6,1 1-12, Prcesteskriftets begrundelse for den store vandflod. De, der skulle vœre Jahves børn, Jes 1,2, er blevet helt anderledes. Verberne svigte, עזב, og lade hånt om, נאץץ, bruges om pagtsbrud i Deut 31,20, der handler om at vende sig til fremmede guder og forkaste Jahve som deres Gud, hvilket svarer godt til Jes 1,4.

At det er Israels Hellige, de har vendt sig fra, er med til at understrege den markante forskel mellem Gud og syndige mennesker. Det er samme tankegang, der findes i Jes 6,1-7, hvor Jahve lovprises som hellig, og hvor profeten gribes af skrcek, fordi han som syndigt menneske har set Gud. Først efter omhyggelig renselse kan profeten trœde i den hellige Guds tjeneste. At forholdet til andre 
mennesker og forholdet til Gud omtales side om side svarer til De Ti Bud, hvor første del handler om forholdet til Gud, mens anden del handler om forholdet til mennesker (samfundet).

Skildringen af den sønderslåede krop i vers 5-6 skal vise, at folket allerede er straffet, men at de alligevel er villige til at modtage flere prygl, selv om der knap nok er plads til mere. Det er ikke klart, om Israel er tegnet i billedet af en oprørsk slave, eller faderbilledet stadig skal tcenkes med, så der er tale om en noget hårdhœendet børneopdragelse i stil med formaningen i Ordspr 13,24: "Den, der elsker sin søn, tugter ham i tide." Slagene har ramt hele kroppen, og ingen har taget sig af den forslåedes sår.

Parallelt med skildringen af den straf, folket har fået, står en skildring af, hvordan også landet er blevet ødelagt, v. 7-9. Skildringen minder om, hvordan der ser ud, når et land er blevet harget af fjendtlige hœre, der har nedbrœndt ikke blot byerne, men også afgrøderne på marken. Som sammenligning henvises der til fortœllingen om Sodomas ødelœggelse (under forudsctning af tekstrettelse), hvor det også er ilden, der er Jahves redskab til at ødelœgge byen med, Gen 19.

Med vers 7-8 vendes blikket fra folket til deres land. At et land lider under beboernes ulydighed mod Jahve fremgår også af Hos 4, 1-3, hvor profeten i en retstale anklager folket for ikke at kende Gud og bryde budene (de forbander, lyver, drœeber, stjœler og begår œgteskabsbrud, jf. Ex 20). På grund af dette sørger landet, og ikke alene mennesker, men også dyrene omkommer. I Jes 1,7-8 er ødelœggelsen skildret som resultatet af fjenders hœergen med nedbrcending af byer og plyndring af afgrøderne. Og alligevel er der et glimt af håb: Netop fordi ødelœggelserne forstås som et resultat af Jahves straf over det frafaldne folk, og ikke som udtryk for at folkets fjender (og deres guder) er stœrkere, er det også Jahve, der kan skåne Zions datter, dvs. Jerusalems indbyggere. Billedet af hytten i vingården og vagtskuret i melonmarken viser, hvor lidt der er tilbage. For første gang i Jesajabogen er det resttanken, der antydes (se ncermere i kommentaren til Jes 7,3).

At der tales om en hytte kan indebcre nogle konnotationer, der peger i en mere positiv retning. Et par steder i Salmernes Bog kaldes Jahves bolig for en hytte, סכת. I SI 76,3 hedder det, at Jahve fik sin hytte i Salem, dvs. Jerusalem, og parallelt hermed nœvnes Jahves bolig på Zion. I SI 31,21 står det at vare gemt i Jahves hytte parallelt med at vœere i hans ansigts skjul. I den sammenhœeng er templet stedet, hvor man kommer for at se Guds ansigt (se også kravene om tre gange årligt at komme og se Jahves ansigt i Ex 23,17; Ex 34,23). I Am 9,11 er det Davidsriget, der kaldes en hytte. Glosen o kan derfor signalere at vœre under Jahves beskyttelse. Dette passer godt sammen med 
vers 9, hvor det understreges, at det er Jahve, der har sørget for, at nogle få er blevet levnet (se også Jes 4,6).

Sammenligningen med et vagtskur fører tanken videre til udtrykket en belejret by. Participiet נצורה kan løeses på to forskellige måder. Enten er det participium passiv af roden מצר, hvilket vokalisationen peger på, og i så fald betyder det bevogtet, eller også er det participium nifal af roden צור (med cendret vokalisation) og betyder belejret. DO har valgt at gengive glosen med belejret og dermed tydeliggjort, at der tœnkes på en situation, hvor fjenderne står rundt om byen (jf. Jes 7,1 og folkekampmyten i fx SI 2). Lœst i forlœengelse af billederne af hytte og vagtskur, er det dog lige så naturligt at forstå byen som bevogtet af Jahve selv. På dansk er vi nødt til at vœlge én af betydningerne, men på hebraisk er det muligt at fornemme et ordspil mellem de to betydninger og dermed lade det stå åbent, hvor truet byen er.

DO 1992 har, ligesom mange forskere, valgt at lœgge vœgten på truslen mod Jerusalem. Baggrunden herfor er, at skildringen af den belejrede by passer godt til en politisk begivenhed, der netop falder inden for den periode, hvor profeten Jesaja ifølge Jes 1,1 forkyndte om Juda og Jerusalem. I 701 f.Kr. belejrede assyrerkongen Sankerib Jerusalem. Det fremgår af Det Gamle Testamente, 2 Kong 18,13-19,37, at Sankerib opgav belejringen. Der gives to forklaringer, dels at kong Hizkija betaler Sankerib for at opgive at erobre Jerusalem, 2 Kong 16,8, dels at Jahves engel drcbte 185000 mand i assyrerlejren, 2 Kong 19,35-37 (se også Jes 36-37). Mens den ene peger på kongens politiske indsats, giver den anden en teologisk tolkning af den begivenhed, der endte med, at Sankerib forlod Jerusalem og opgav belejringen.

Begivenheden kan yderligere belyses gennem en assyrisk version, hvor Sankerib fortceller, at han indesluttede og erobrede 46 af byerne i Juda og også spcerrede kongen selv inde i Jerusalem som en fugl i et bur. Men Sankerib fortceller ikke, at han erobrede Jerusalem, hvilket må betyde, at han måtte opgive belejringen uden at erobre byen.

\section{Faktaboks: Sankeribs erobringer}

Uddrag af Sankeribs beretning om felttoget 701 f.Kr.

Efter at have berettet om sine hidtidige sejre fortsœtter Sankerib med en skildring af, hvordan han belejrede Jerusalem og aftvang Hizkija store "gaver": 
"Dernœest Judœeeren Ezekias [Hizkija], som ikke havde bøjet sig for mit åg, - jeg indesluttede 46 af hans stcrke befœstede byer samt utallige andre små byer i deres omgivelser; jeg indtog dem ved anlœggelse af transport-svelleveje og fremførelse af belejringsmaskiner, ved fremstød af hurtigt fodfolk, ved brydning af brecher, demolering og anvendelse af stormstiger 200150 mennesker, okser og får uden tal førte jeg bort derfra og regnede som bytte. Jeg spcerrede ham selv inde i hans kongestad Jerusalem som en fugl i et bur. Jeg lagde faste varker mod ham og betog ham enhver lyst til at gå ud af hans bys port. De af hans byer, som jeg havde udplyndret, udskilte jeg fra hans land, og jeg gav dem til kong Mitinti af Asdod, kong Padi af Ekron og kong Sil-bel af Gaza, hvorved jeg formindskede hans land. Til den tidligere afgift - deres årlige gave - føjede jeg en gave for forbundet med min herskerpersonlighed og pålagde dem (det således). Ham selv, Ezekias [Hiskija], overvœldede frygt for glansen fra min herskerpersonlighed, og de Arabere (?), samt deres (?) gode krigere, som han havde optaget til at styrke sin kongestad Jerusalem, hvorved han havde opnået understøttelse, tillige med 30 talenter guld og 800 talenter sølv, œdelstene, antimonsminke, store blokke rødsten, elfenbens divaner, elfenbensstole på underlag af trin (?), elefanthud, elefant-tand, ahorn (?), buksbom, dragter af broget stof og linned, blåt og rødt purpur, redskaber af kobber, jern, bronze, bly og jern (!), kampvogne, skjolde, lanser, pansere, dolke af jern til baltet, buer og pile, - våben og kamp-udstyr uden tal - tilligemed hans døtre, hans palads-damer og sangere og sangerinder lod jeg føre efter mig helt til min herskerstad Ninive, og han sendte sine ryttere for at overbringe gave og gøre trœlles gerning."

Jf. til overscttelsen Benedikt Otzen, 1977. Israeliterne i Palcestina. Det gamle Israels historie, religion og litteratur. København: G.E.C. Gad, 335-336.

Billedet af kongen som en fugl $i$ et bur minder om beskrivelsen af den belejrede by, der ligger isoleret som en hytte eller et vagtskur, men uden de positive konnotationer, som findes i den gammeltestamentlige tekst.

Kontrasten til den reddede by er de to byer, som ifølge Gen 19 blev ødelagt af Jahve som følge af deres syndighed, Sodoma og Gomorra. Havde Jahve afsluttet sin retssag mod folket med at lade retfœrdigheden ske fyldest, så var det gået som med Sodoma og Gomorra. Men det skete ikke. Derimod gik det, som det fremgår af folkekampmyten, at selv om fremmede folk vender sig mod Jerusalem, så vil Jahve selv beskytte byen, SI 46 og 48 (se også SI 2). Forestillingerne om Zions uindtagelighed er uden tvivl blevet yderligere forstcrket af erfaringerne i 701 f.Kr. (se nœrmere om Zionideologien (Zionteologien) i kommentaren til Jes 2,1-5 samt DKDSI, 90-92 ). Men teksten løegger ikke skjul på, at Jerusalem kun er en lille del af landet. 
10-17

Dette orakel er henvendt til såvel lederne som folket. Med opfordringen til at høre skabes der en vis parallelitet til Jes 1,2, hvor Jahve anklager sit folk. Oraklet bestemmes klart som et ord fra Jahve, hvilket svarer godt til opfattelsen af profeten som Jahves talerør. Derudover bestemmes ordet som belœring, תורה, der ud over at betyde belœring også kan bruges om Jahves lov (jf. brugen af glosen i SI 1,2). Med bynavnene Sodoma og Gomorra knyttes der til ved det foregående orakel, og lederne og folket karakteriseres negativt ved at sammenlignes med folk i de to berygtede byer, (jf. Jes 1,9 og Gen 19). Afsnittet indeholder en voldsom kultpolemik. Umiddelbart kunne man få indtryk af, at profeten afviser enhver form for kult. Men det er nœppe det, der er meningen (se nœermere i Kirsten Nielsen 1976). Der er tydeligvis tale om nogle bestemte ofre, jeres ofre, og ikke dermed automatisk ethvert offer. Profeten taler ind i en konkret situation. På gammeltestamentlig tid var offervœsenet en helt afgørende del af dyrkelsen af Jahve, hvilket også fremgår af planerne for det nye tempel i Ez 40,47 og Ez 43,13-27, som man ikke kunne forestille sig uden et stort alter til offerkulten.

Nøglen til forståelsen af polemikken er vers 13, der angiver årsagen til Jahves afvisning af kulten: kult kan ikke stå alene. Hvis folket ikke adlyder Jahve i det daglige liv med hinanden, dvs. følger hans etiske krav, så mister kulten sin betydning. Offeret virker ikke som magi over for Jahve. Det er kombinationen af festdag og ondskab, der fremkalder Jahves vrede. I SI 50 findes en tilsvarende kritik af kult og manglende etik. I den følgende salme, SI 51, genindscttes kulten på sin rette plads efter salmistens syndsbekendelse (se ncrmere i DKDS II til SI 50 og 51).

De nœvnte ofre svarer til de ofre, som der gives love for i Tredje Mosebog (se nœrmere om de gammeltestamentlige offertyper i Hans Jørgen Lundager Jensen 1998). Det drejer sig i v. 11-12 om slagtofre, Lev 3. Slagtofre består af husdyr, og dele af dyret brcendes på alteret. Det er Jahve, der på den måde får indvoldsfedtet, noget tilfalder prcesterne, og resten spises af dem, der bringer offeret. Et vigtigt element er således den fœlles spisning. Slagtofre, også kaldet måltidsofre, bringes nok iscer i forbindelse med familiefester. Brcendofferet, Lev 1, spises ikke. Det består af husdyr og brœndes helt, dog tilfalder skindet prcesterne, Lev 7,8. Brcendofre anvendes ved mange forskellige lejligheder, bl.a. som udtryk for taknemmelighed eller for at forsone Jahve. I v. 13 ncevnes afgrødeofrene, Lev 2. Disse består af korn, mel eller brød, og kun en lille del brœndes. Resten spiser prœsterne. Årsagen til at bringe et afgrødeoffer svarer til årsagen til brcendofferet, og ofte bringes de to typer sam- 
men. Også røgelsesofferet, Lev 16,12-13, kan bruges til at formilde Gud med, det er en gave, der skal glœde Gud ved hjœelp af den liflige duft.

Hvor den normale situation ville vœre, at Jahve modtog ofrene og lod sig mœtte af dem, hedder det her i Jes 1,11-13, at Jahve allerede er mat og ikke vil have ofrene. At ofrene bringes ved templet fremgår af v. 12, hvor udtrykket at se mit ansigt er en fast formel for at komme til helligdommen, Ex 23,15; 34,23-24; Deut 16,16. Det samme fremgår af henvisningen til mine forgårde. Hele tumlen omkring helligstedet er ubehagelig for Jahve. I hans øjne er deres afgrødeofre tomme eller måske snarere en form for bedrag. שיא kan ud over tomhed betegne falskhed. At lugten af røgelsen er ubehagelig viser, at Jahve netop ikke kan nyde, hvad der er tcenkt som nydelse.

I forlœngelse heraf nœvnes festdagene, hvor folk strømmer til templet. At man har fejret Nymånedagen, afspejler kalendersystemets betydning for fastløeggelsen af helligdage (se også SI 104,19). Den festligholdes med ofre, Num 10,10, og fallesspisning, 1 Sam 20,5. Sabbatten er den ugentlige hviledag, Gen 2,2-3. Ordet festforsamling markerer, at folk kaldes sammen, קרא מקרא, til festligholdelse af bestemte helligdage.

Afvisningen af kombinationen af ondskab og kultfest er oraklets pointe. Glosen און betegner det onde og uheldsvangre, som bringer ødelceggelse og derfor udvirker det modsatte af det, som kulten skulle medføre. Netop derfor er det imod Jahves vœsen.

Med v. 14 forstcrkes beskrivelsen af Jahves modvilje, Jahve hader den måde, de fejrer ham på. Festerne er blevet en plage i stedet for en glœde for Jahve. Afvisningen gœider i v. 15 også folkets bønner. Både de synlige tegn på bøn, de fremstrakte hœender, og lyden af deres bønfaldende ord, afvises. Jahve gør sig både blind og døv over for dem (jf. hertil forhcrdelsesbudskabet i Jes 6,9, hvor det er folkets øjne og ører, der ikke fungerer). Begrundelsen for at afvise selv deres bønner angives straks efter: De har blod på haenderne! Blodet kan stamme fra deres mange ofre, som Jahve netop har afvist. Men lœest som baggrund for den følgende formaning til at holde op med at øve ondt, kan det også vœre blodskyld, der er tcenkt på (se SI 51,16). Blodet afslører deres onde handlinger (jf. at Abels blod ifølge Gen 4,10 råbte til Jahve fra jorden). Bønnen er heller ikke en magisk handling, der virker uanset, hvordan de i øvrigt lever deres liv.

Det er dog ikke nok at rense sig og holde sig fra ondt, de skal handle godt, v. 16-17. Udtrykket er meget generelt, men praciseres straks efter med henvisning til de sociale forhold: Det er de svage i samfundet, de skal tage sig af. Heri ligger, at de skal lade vare med at unytte deres egen magtposition over for dem, de har magten over. Og endnu mere pracist peges der på samfundets 
svageste, den faderløse og enken. I et samfund, hvor manden i huset har ansvaret for sin families ve og vel, er netop den kvinde, der har mistet sin mand, og det barn, der ingen far har til at sørge for sig, ilde stedt. Det er karakteristisk for gammeltestamentlig etik, at de marginaliserede og udsatte, ofte omtalt som den fremmede, enken og den faderløse, skal beskyttes, fx Ex 22,20-21; Deut 24,17; Deut 27,19; Jer 7,6; 22,3, ligesom Gud selv er beskrevet som enkernes beskytter, Deut 10,18.

$18-20$

Med opfordringen til at holde rettergang (jf. Jes 1,2) åbnes der for en fornyet refleksion over forholdet mellem Jahve og folket. At det er folket, der er på anklagebœnken, fremgår af, at Jahve fokuserer på deres synder. Verset kan oversœttes på tre forskellige måder: I DO 1931 er det oversat: "Er eders Synder som Skarlagen, de skal blive hvide som Sne; er de end røde som Purpur, de skal dog blive som Uld." Forstået på denne måde indeholder verset et løfte om tilgivelse, og sådan er det også gengivet i den grœske oversœttelse, Septuaginta. Selv om synderne er dybt alvorlige (jf. de blodfarvede hcender i vers 15), så kan Gud fjerne dem, så hans folk fremstår rene som sne og uld. I så fald er det frelsesforkyndelse.

Ordene kan også overscettes som et retorisk spørgsmål: "Hvis jeres synder er som skarlagen, kan de så blive hvide som sne? Hvis de er røde som purpur, kan de så blive hvide som uld?" I så fald er betydningen den stik modsatte. Selvfølgelig kan rødt ikke blive hvidt. Denne måde at formulere sig på, svarer til, at der efter den korte retstale i vers 2-3 kommer et veråb. Det er nødvendigt at straffe det syndige folk og ikke lade som om rødt og hvidt er det samme. I så fald er det domsforkyndelse.

I DO 1992 har man valgt den tredje mulighed. Rødt kan blive til hvidt under scerlige forudscetninger. Konteksten, v. 19-20, opstiller to valgmuligheder: De kan adlyde Jahve, og så skal det gå dem godt, eller de kan vare genstridige, og så skal de dø. Dette taler for, at DO 1992 rammer rigtigt ved at holde muligheden for et positivt udfald åben. Om Jahve vil rense dem, afhcenger af, hvilken vej de vœlger at følge. Renselsesmotivet findes mere udførligt anvendt i det følgende orakel (se v. 25).

At de skal fortcre landets goder, skal ses i lyset af de barske vilkår, der kendetegner et land, hvor fjenderne hœerger og ødelœegger afgrøden. Jahves forbandelse beskrives i Deut 28,30 som det at plante en vingård, men ikke selv kunne tage den i brug, og i Deut 28,33 som det ikke at nyde frugten af sin jord og udbyttet af sit slid, fordi fremmede kommer og tager det fra en. Velsignelsen er 
pracis det modsatte. At vœre velsignet er, selv at kunne nyde frugten af sit slid, så der bliver sammenhceng mellem indsats og resultat. Afsnittet rundes af med endnu en understregning af, at ordene kommer fra Jahve selv.

\section{$21-28$}

Klagen over at Jerusalem er blevet som en skøge indledes med udtrykket איכה. Dette udtryk anvendes i klager, fx Klages 1,1 og 4,1, når man klager over, at noget er sørgeligt forandret. Sammenligningen mellem den tidligere storhed og den nutidige elendighed minder om, hvordan man i ligklager sørger over, at den, som tidligere var levende, nu ligger død hen (se dødsklagen over Israel i Am 5,1-9). Lande og byer sammenlignes ofte med kvinder, og en bys eller et lands frafald fra Jahve kan derfor beskrives ved hjœlp af skøgemetaforik (se fx Ez 16 om Jerusalems utroskab og Ez 23 om Samaria og Jerusalem). At svigte Jahve er som at vœre utro mod œgtemanden.

I Jes 1,21-28 består Jerusalems utroskab i moralsk forfald. Derfor indeholder klagen også anklage, og der sker dermed en kombination af to Gattungen: ligklage og retstale. Tidligere var byen og dermed dens indbyggere retfœrdige mennesker, der rettede sig efter de ordninger og love, som skulle få samfundet til at fungere, nu bryder de loven og begår mord. Med billedet af sølvet og vinen tydeliggøres det, at det, som engang var vœrdifuldt, nu er blevet mindre vœrd. Billedet udlœgges i det følgende vers, v. 23, med en anklage mod de ledende i samfundet. Deres oprørskhed består i lovløshed: De stjœler (jf. SI 50,18 og forbuddet mod at stjœle i Ex 20,15), og de tager mod bestikkelse (se loven mod bestikkelse i Ex 23,8 og Deut 16,19). Uretmcessigt tilegner de sig andres ejendom, og de tager parti for den, der kan betale for det, de gør sig med andre ord skyldige i korruption. Derfor er det som altid de svageste, den faderløse og enken, det går ud over, Jes 1,17. Og fordi etikken og gudsdyrkelsen ikke kan skilles ad, er deres oprørskhed oprør mod Jahve.

Efter anklagen følger kendelsen, der i dette tilfclde indeholder dom over de anklagede, men også her i form af et veråb, v. 24. De, der gør sådan, er dødsens! Jahve omtales som Herren, הארון, Hcerskarers Jahve, יהוה צבאות, og Israels Mcegtige, אביר ישראל. Alle tre epiteter understreger Jahves magt. Han har herskermagt (jf. kongenavne som Adonibezek, Dom 1,5, og Jerusalems konge Adonizedek, Jos 10,1). Som en krigerkonge har han hœre under sig (jf. Jes 13,4-5, hvor hœrene både er jordiske og himmelske; se mere herom i gennemgangen af Jes 3,1). Og over for Israel er han, אביר. Glosen betegner et dyr, tyren, Jes 34,7, men overscttes ofte ved det for tyren karakteristiske, dens styrke. Muligvis ligger der dog religionshistorisk set rester af forestillinger om Jahve i skikkelse af en tyr 
bag ved betegnelsen (jf. guldkalvene i Dan og Betel, 1 Kong 12,26-33; se også Ex 32). Der står således magt bag truslen om Jahves haevn mod Jerusalems ledere, her netop omtalt som fjender og modstandere.

Hœvnen beskrives som en renselsesproces, hvor de dårlige elementer fjernes fra det rene metal. Kun de urene slagger og blyet, som er affaldsprodukter, når man udskiller sølv, bliver nœvnt; men lœest i forlœngelse af vers 22, er det adskillelse af sølvet og affaldsstofferne, det drejer sig om. At det er billedet af en renselsesproces, der anvendes, medfører, at der også er håb for en rest, nemlig dem, der kan sammenlignes med sølvet (se nœrmere til resttanken i kommentaren til Jes 4,3 og 7,3).

I vers 26 uddybes resttanken. Der skal nye ledere til for at gøre byen retfcerdig og trofast. Jahve vil genoprette den tidligere tilstand, hvor der herskede retfœrdige tilstande, og Jerusalem var trofast over for Jahve. Sandsynligvis tœnkes der på Davidstiden som en sådan idealtid. I den jesajanske forkyndelse, hvor Jerusalem og Juda er i centrum, er tiden under David og muligvis også Salomo en form for urtid, hvor alt var, som det skulle vare. Fremtidsforventningerne formuleres som en genoprettelse af denne urtid.

I det følgende vers, v. 27, tales der om udfrielse af Zion. Det hebraiske verbum, פרה, som i DO 1992 er gengivet ved at udfri, anvendes i forbindelse med handelsaktioner, hvor man frikøber fx en slave. Verbet kan også anvendes i kultisk sammenhœeng, hvor man kan frikøbe sin førstefødte søn, så han ikke skal ofres til Jahve, Ex 13,13-15. Betalingen for Zion og byens indbyggere er ret og retfœrdighed. Det siges ikke direkte, hvis ret og retfœrdighed, der er betalingsmidlet, men det må vœre indbyggerne, der skal leve retfœrdigt. Set i forlœengelse af de foregående vers og af v. 28 er det dog Jahve, der ved at rense byen og lade ulykke ramme dem, der har brudt hans lov og derigennem svigtet Jahve, skaber muligheden for, at byen igen kan blive retfcerdig.

Den jesajanske opfattelse af Jerusalem som Jahves udvalgte by indebœrer ikke, at indbyggerne til enhver tid kan føle sig sikre på, at Jahve vil beskytte dem. Udvœlgelsen indebœrer nemlig krav til indbyggerne om at vare trofaste over for Jahve. Nok er de børn af Jahve, Jes 1,2, men af børn krœves lydighed.

\section{9-31}

Kapitlets sidste afsnit har givet anledning til forskellige tolkninger (se ncermere i Kirsten Nielsen 1985 , 306-324). Afsnittet fungerer som endnu en kendelse, hvor der i forlcengelse af det foregående udtales dom over de tiltalte. Men sprogbrugen er en anden. De centrale gloser har med egetrcer og ha- 
ver at gøre. Begge gloser bruges i såvel v. 29 som v. 30. Oraklet kan tolkes som kritik af scrlige former for kult, hvor israelitterne har dyrket hellige trœeer (jf. Jes 57,5; 65,3; se også Hos 4,13; Jer 2,2027). At haver har vœeret brugt til kultiske formål fremgår af fx Jes 65,3 og Jes 66,17 . Formålet med traedyrkelsen er at skaffe sig liv og frugtbarhed. Men pointen er, at de opnår det stik modsatte. I kanaanœisk religion er symbolet for den kvindelige guddom, Ashera, netop et trœe eller en trœpœl, $\mathrm{fx}$ Deut 16,21; 1 Kong 14,15 og 2 Kong 23,6.

Hos Jesaja fører folkets dyrkelse af hellige trœer kun skuffelse og skam med sig. Dette viser sig ved, at de selv mister livskraften, de visner som et trce og som en have uden vand, v. 30. Fra visne blade og tørke føres billedet videre til den ultimative form for tørke, hvor ilden opbrcnder alt, både den stœrke og hans vœrk. I forlœengelse af beskrivelsen af dyrkelsen af afguder i form af trœer giver det god mening at tolke den stœrke som afgudsdyrkeren, dvs. folket selv. Når de i v. 30 omtales som en eg, kan det meget vel afspejle deres selvopfattelse. De mener sig stcrke som egetrcet, men den selvopfattelse er forkert. De skal tvartimod miste al livskraft og visne.

Med v. 31 fokuseres der på den enkelte, der opfatter sig selv som stœrk. Hans vark kan vœre den afgud, han selv har skabt. Og nu får de to samme skœbne, de brcnder op. At det ender med ildebrand kan ikke undre, når folket er skildret som visnende trœer (jf. Ez 19,10-14). At ingen kan slukke branden viser, at der er tale om en total udslettelse.

Oraklet kan tolkes som kritik af afgudsdyrkelsen; men der kan vœre endnu et lag i teksten. Trœet anvendes andre steder i Jesajabogen som billede på konger, Jes 6,13; 10,33-1 1,1.10 (se også Ez 31). I Jes 7,4 er det de to fjendtlige konger, der omtales som to rygende stykker trœ, som kong Akaz ikke behøver at frygte, da de forsøger at presse ham ind i en falles koalition mod assyrerne. I Jes 2,6-17 forbindes afgudsdyrkelse og politiske transaktioner med hinanden (se ncrmere i kommentaren til teksten samt Jes 17,1-11). Hvis Jes 1,1-2,5 skal fungere som programmatisk indledning til Jesajabogen, må man forvente, at et så vigtigt tema som de politiske forhold med forsøg på alliancer med fremmede magter også er reprcesenteret her i begyndelsen. En nœrliggende mulighed er derfor, at billedet af de store trœer, der brcender op, ikke kun hentyder til afgudsdyrkelse, men også til udenrigspolitikken og dens ødelœggende konsekvenser. For at stole på de fremmede kongers politiske magt og dermed på de guder, der står bag dem, er ifølge Jesajabogen at svigte Jahve, Jes $31,1-3$

I så fald kan hovedtanken gengives således: I skal kun få skam af de fremmede konger, I har valgt som jeres koalitionspartnere i tillid til, at de er stcerke som de hellige trceer og som de guder, 
trœerne symboliserer. I selv skal blive som udtørrede trœer. Og den stcrke, som I ville støtte jer til, skal blive årsagen til, at han selv og alt det, han har udrettet, går op i flammer.

Oraklet indeholder en rœkke ordspil, som er med til at skabe såvel flertydighed som sammenhceng. Verbet בישו i v. 29 betyder "de skal blive til skamme" og er en form af verbet בושי Ofte rettes verbet til 2. person pluralis, "I skal blive til skamme", hvilket ville passe bedre rent grammatisk med resten af verset. Men bevares teksten opstår der et ordspil på verbet at tørre ud, שיב, hvilket passer godt til motivet: udtørring og ildebrand i v. 30-31, og bidrager til at skabe en helhed af de tre vers. Den hebraiskkyndige vil i konteksten kunne høre begge betydninger, hvis teksten bevares i den foreliggende form. Dette understøttes af, at de to verber, יבש og מושי, flere gange bruges sammen i Det Gamle Testamente (se fx Jes 19,5-9; 42,15-17 samt SI 129,5-6).

Jes $2,1-5$

1

Kapitlet begynder med endnu en overskrift, der i modscetning til overskriften i Jes 1,1 ikke indeholder nogen tidsangivelse, men blot ncevner, at synet gœelder Juda og Jerusalem. Om overskriften oprindelig har vœeret indledningen til en større eller mindre samling af orakler, er ikke til at afgøre. Det er dog muligt at se den som et tegn på, at Jesajabogen er blevet til gennem sammenføjning af foreliggende samlinger af orakler, som har vœret forbundet med profeten Jesajas forkyndelse. Overskriften kan dog også have en meget mere begrœnset funktion, så den kun gœlder versene 2-4. Disse vers findes nemlig i stort set samme form i et andet profetskrift, Mika 4, 1-3. Det er derfor en mulighed, at der har vœret uenighed om, hvem der egentlig har udtalt oraklet, Jesaja eller Mika. For at prœcisere, at det var Jesaja, har en redaktor eller en afskriver indføjet overskriften.

\section{$2-4$}

Oraklet er en forjœttelse om en lykkelig fremtid. Formuleringen באחרית הימים, der i DO 1992 gengives ved "til sidst", skal ikke tolkes som udtryk for en fjern fremtid, men som en tid, der gør en ende på den nuvcerende krisetid. Når den straf, som Jesaja har forkyndt om i kapitel 1, er indtruffet, og den rensede rest står tilbage, så kommer den tid, hvor forholdet mellem Jahve og verden er genoprettet, og alle folk kan leve i fred belœrt af Jahves ord. 
Til den tid skal bjerget med Jahves hus, templet, vœre urokkeligt. Hermed siges ikke blot noget om bygningen, men også om Jahve, som bor deri. Ophøjelsen af tempelbjerget skal ses som udtryk for, at det er her axis mundi, verdensaksen, befinder sig. I Genesis findes forskellige eksempler på, at et bestemt sted skildres som mødested for jord og himmel. I Gen 11 er det Babelstårnet, der forbinder byen med den himmelske verden. Jahves indgriben viser dog, at Babel ikke er den rigtige axis mundi. I Gen 22 er bjerget i Morija mødestedet for den himmelske verden og Abraham. At dette bjerg har vœeret opfattet som Jerusalems bjerg fremgår af 2 Krøn 3,1, hvor det fortcelles, at Salomo byggede sit tempel i Jerusalem på Morijas bjerg. I Gen 28 udpeges Betel gennem Jakobs drøm om stigen, der går fra jord til himmel som endnu en axis mundi, mens profeten Amos i sin forkyndelse fordømmer Betel, Am 5,5-6, som et sted med falsk gudsdyrkelse. I forbindelse med ørkenvandringstraditionerne er det på Sinaj bjerg, Jahve mødes med Moses (se Ex 19, hvor Moses fungerer som mellemmand mellem Gud, som er på bjergets top, og folket ved bjergets fod). I den jesajanske forkyndelse er der, ligesom i Det Deuteronomistiske Historievœrk (jf. Josijas reform, 2 Kong 23) ingen tvivl om, at det rigtige helligsted findes i Jerusalem på Zion.

I Det Nye Testamente holder Jesus netop en bjergprcediken, Matt 5-7, ligesom Jesu forklarelse finder sted på et bjerg, Matt 17,1-13 (se også Matt 4,1-11 og Luk 4,1-13 om Jesu fristelse, der også er forbundet med et højt sted). Bjerget er stedet, hvor jord og himmel mødes.

At bjerget skal vœre højere end alle andre betyder netop, at det skal vœre det virkelige forbindelsesled mellem Gud og verden. Tilsvarende forestillinger kendes fra Zionhymnen, SI 48,3, hvor det hellige bjerg i Guds by skildres som smukt knejsende og placeres "i det yderste nord", dvs. i det mytologiske nord, hvor guden Ba'al ifølge kanaanceisk religion bor (se også Jes 14,13). Da der til den tid ingen tvivl er om, hvor Gud vil mødes med menneskene, er den nye situation også karakteriseret ved, at alle folkeslag vil samles om Jahves bolig i Jerusalem. Oraklet er således stœrkt prœget af den Zionteologi, som kendes fra Zionsalmerne (se ncermere i DKDSI, 90-92 samt DKDS II, 161-162 ; se også Benedikt Otzen 1986).

I v. 2-3 skildres folkenes komme som en valfart til et helligsted. Verbet drage op, עלה, v. 3, er fast term for at drage på valfart op til Jerusalem (jf. valfartssangene, שמעלות, SI 120-134; se ncrmere i DKDS III, 200-202). Verbet נהר, at strømme, v. 2, er ikke tilfceldigt valgt. Det spiller på forestillingerne om, at Jerusalem er forbundet med en scerlig flod, נהר, som skaber glœde i byen med sit vand, SI 46,5. 
Det afgørende i visionen om folkeslagene er tanken om, at ikke kun Jahves eget folk, men også de fremmede skal underkaste sig Jahve som den sande Gud. Andre steder i Jes 1-12 er de fremmede folk opfattet som fjender, men dog underlagt Jahves magt (se fx Jes 7 samt Jes 10, hvor assyrerkongen er Jahves redskab til at straffe hans eget folk). Tilsvarende forestillinger om en lykkelig fremtid findes i forjcettelserne om den nye konge i Jes 9,2-6 og i Jes 11,1-10.

Målet for valfarten er Jahves bjerg, der yderligere betegnes som Jakobs Guds hus. Omtalen af Jahve som Jakobs Gud er uscedvanlig i Jesajas forkyndelse, men findes i flere salmer, SI 20,2; 46,8.12; 75,10; 76,7; 81,2.5; 84,9 og 94,7 (se også SI 24,6, hvor teksten rettes i DO 1992). Jakob er i gammeltestamentlig tradition folkets stamfar, Gen 32,29, og omfatter på den måde hele det israelitiske folk. Jakob signalerer her "gamle dage" før rigets deling og Nordrigets undergang.

Formålet med valfarten er at modtage vejledning fra Jahve. Vej og sti bruges hyppigt i Det Gamle Testamente som billede på selve livet, fx SI 1 19,25-32. At Jahve skal vise dem sine veje, så de kan følge dem, betyder derfor at få indsigt i og leve efter Guds vilje. Ordet תורה betegner tilsvarende belcering om Jahves vilje.

Med v. 4 uddybes indholdet af Jahves vilje. Jahve skal optrœde som dommer over alle folkene. Rettergangsterminologien (verberne יכח og שפט skaber forventninger om, at nogle skal straffes, mens andre skal frikendes, fx Jes 1,18; 11,3-4 og 1,17.23; 5,3. Men i skildringen af denne rettergang bevœger profeten sig direkte frem til konsekvensen af Jahves dommervirksomhed, nemlig at herefter skal alle stridigheder ophøre. Vœegten ligger ikke på domsproceduren, men på den lykkelige situation bagefter, hvor freden hersker, og der ikke lœengere er brug for våben, men derimod for redskaber til at dyrke jorden med (jf. den modsatte opfordring i Joel 4,10, hvor der udråbes hellig krig, og der lyder en opfordring til at smede plovjern og vingårdsknive om til svcrd og lanser).

Krig rammer ikke blot mennesker, men også agerjorden. Freden betyder derfor også, at jorden nu kan blive dyrket (jf. Mika 4,4, hvor konsekvensen af krigens ophør er, at man kan sidde i ro under sin vinstok og sit figentrc). Markerne kan blive pløjet, så kornet kan sås og høstes, og vinstokkene blive beskåret, så de kan bœre god frugt. De nœvnte redskaber angiver to meget vigtige afgrøder: korn og vindruer. Forudscetningen for, at det er redskaber til det daglige arbejde ved landbruget, der er brug for, er krigens ophør. Ikke blot skal de forskellige folk ikke løengere gå i krig med hinanden, men den viden, man har haft om krig, og som er blevet givet videre fra generation til generation, skal forsvinde. At Jahve gør en ende på krig kendes også fra SI 46,10, men her ødelœgger Jahve selv våbnene og erstatter dem ikke med nyttigere ting. 
Oraklet afsluttes med en gensidig opfordring henvendt til Jakobs hus, dvs. Jahves eget folk. At vandre i Jahves lys er et billedligt udtryk for at følge Jahves vilje. Samme tanke blev formuleret i v. 3; men metaforvalget giver mulighed for endnu nogle betydningspotentialer i forhold til v. 3. Lyset er et billede på oplysning (jf. SI 1 19,105: "Dine ord er en lygte for min fod, et lys på min sti."). Men lyset kan også konnotere velsignelse. I den aronitiske velsignelse lader Jahve sit ansigt lyse og giver dermed den velsignede del i hans nåde, Num 6,25. I Jes 10,17 bruges udtrykket Israels lys om Jahve selv parallelt med Israels Hellige. Billedet af lyset er desuden forbundet med tanken om retfœrdighed (jf. forbindelsen i SI 19 mellem solen og retfœrdigheden). I Det Nye Testamente genbruges lysmetaforikken i Jesu selvbetegnelse: "Jeg er verdens lys", Joh 8,12, og i beskrivelsen af Jesu komme i Johannesprologen, hvor Jesus kaldes "Lyset, det sande lys, som oplyser ethvert menneske...", Joh 1,9. Til gengœeld er det i kristen tradition ikke Jesus, der kaldes lysbœreren, Lucifer, men derimod djœvelen.

Med v. 5 slutter den programmatiske del, Jes 1,1-2,5. De afgørende temaer er prœsenteret for lœseren, og som en rød tråd ned gennem teksten går rettergangsmotivet. Rettergangen fører $\mathrm{i}$ Jes 1,2-9 til alvorlig anklage og afstraffelse af de ulydige børn. Da retssagen genoptages i Jes 1,1820, opstilles muligheden for frikendelse, hvis de adlyder Jahve. Og i Jes 2,2-5 ligner det en vellykket mœgling mellem folkene med efterfølgende fred og tilbagevenden til hverdagens gøremål på mark og i vingård. Det slutter lykkeligt, men de mellemliggende, kritiske faser hører med og foldes ud igen og igen i det følgende. Jes 1-12 slutter da også med en salme, der kombinerer det positive og det negative: Jahves vrede og Jahves trøst. Denne spœnding mellem dom og frelse er grundnerven $\mathrm{i}$ Jesajas forkyndelse. 
$18 a$

Verbet יחלך står i singularis, men da subjektet er pluralis, og pluralisendelsen r er skrevet sammen med det første ord i v. 19, ובאו, retter DO 1992 med støtte i Qumran til pluralis יחלףו. I v. 19 rettes tilsvarende באו til ובאו.

\section{Karakteristik}

Afsnittet består af forskellige typer af udsagn, der er redaktionelt samlet til en større sammenhœng under temaet: Jahves dag. På Jahves dag skal alle afgudsdyrkerne i folket ydmyges, og kun Jahve selv skal vœre ophøjet. Hovedtanken er, kort formuleret, at hovmod står for fald. Profeten betragter ethvert forsøg på at klare sig uden Jahves hjœlp som udtryk for hovmod. Det gœlder både politiske aktioner, hvor man sctter sin lid til menneskelige krcefter, og afgudsdyrkelse, hvor det er menneskeskabte guder, man stoler på. Udsagnene henvender sig dels til Jahve, v. 6-9, med en opfordring til at straffe de hovmodige, dels til tilhørerne/lceserne, v. 10-22, med advarsler om, hvordan Jahve vil straffe dem. Kapitlet slutter med en visdomssentens om menneskets ringhed.

En stor del af effekten i teksten skyldes den udbredte brug af kontraster, der gør det nemt at se, hvad der er rigtigt, og hvad der er forkert. Brugen af omkvad i v. 9, 11 og 17 (ydmygelsen af mennesket) og den indholdsmcessige lighed mellem v. 11, 19 og 21 (Jahves storhed) er med til at strukturere teksten og skabe sammenhœeng mellem de enkelte udsagn.

Inden for det lœengere afsnit udgør v. 12-17 er scerlig helhed. Dette fremgår ikke mindst af

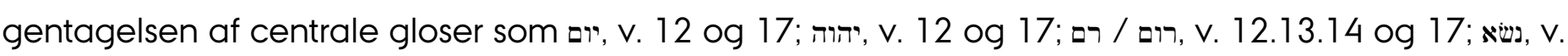

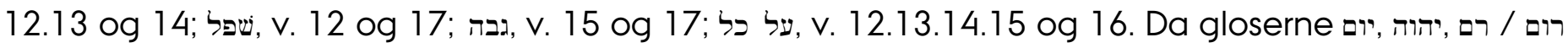
og שפל optrceder i oraklets første og sidste vers (dog i omvendt rœkkefølge i v. 17 i forhold til v. 12), skabes der en klart afrundet form. Desuden markerer disse gloser hovedtemaet: Jahves dag, hvor alt hovmodigt skal ydmyges.

Det er nœppe muligt at afgøre, ved hvilke lejligheder profeten har fremsat sådanne domsudsagn, da de har givet god mening både i forbindelse med den syrisk-efraimitiske krig, Jes 7, 1-9, og senere, når Judas konge har deltaget i oprør mod assyrerne, eller når kongen, som det skete i 701 f.Kr., har betalt sig fra, at Jerusalem skulle blive erobret af assyrerkongen (jf. 2 Kong 16,7-8). Sådanne situationer må ud fra den jesajanske teologi betragtes som tegn på menneskeligt hovmod og dermed som manglende tillid til Jahve. 


\section{Struktur}

6-9 Domsudsagn om Jahves forkastelse af folket på grund af dets afgudsdyrkelse.

10-11 Opfordring til at skjule sig i rœdsel for Jahve og trussel om ydmygelse.

12-17 Trussel om Jahves dag: Hovmod står for fald.

18 Konklusion: Afguderne skal forsvinde.

19 Opfordring til at skjule sig i rcedsel for Jahve.

20-21 Udsagn om folkets forkastelse af afguderne i rcedsel for Jahve.

22 Afsluttende konklusion: Advarsel mod at scette sin lid til mennesker.

\section{Fortolkning}

\section{6-9}

Afsnittet begynder med en direkte henvendelse til Jahve. Lœst uden hensyn til konteksten ligner de første ord "Du har forkastet dit folk" tilsvarende klager i Davids Salmer, fx SI 44,10; 89,39. En sådan klage har også en sncert af anklage, når det er Jahves eget folk, Jakobs hus, der er forkastet. Men nceppe er den lidt forurettede tone slået an, før der gives en udførlig begrundelse for forkastelsen. Klagen får dermed som funktion et kort øjeblik at formulere, hvad der meget vel kan have varet tilhørernes opfattelse: Det er Jahve, der har svigtet os! Men nceppe er de første ord udtalt, før profeten fortscetter med en sprogbrug, der hører hjemme i anklagetaler, hvor Jahves kommende dom skal begrundes. Formålet hermed er at sikre, at Jahve indirekte frikendes for enhver anklage for at have svigtet sit eget folk.

Anklagen mod folket gaelder brug af noget, der kommer fra øst, dvs. noget der er fremmed for Jahves folk. Parallelt hermed prceciseres det, at det er trolddom, og igen markeres det, at det er noget fremmed, nemlig noget filistrene gør. Filistrene omtales hyppigt som Israels fjender (jf. fx Saul og Davids krige mod filistrene, 1 Sam 4-7). Trolddom er udtryk for frafald fra Jahve. Trolddom og varselstagning er forbudt ifølge Lev 19,26 og fordømmes kraftigt i Mi 5,1 1 i et domsorakel, der har meget til fœlles med Jes 2,6. Kort sagt er folkets egenart som Jahves folk truet af de mange fremmede og deres ugudelige skikke.

I v. 7 kritiseres de for deres rigdomme og krigsmateriel. Både rigdommen, hestene og stridsvognene er udtryk for, at de stoler på egne krœfter i stedet for at stole på Jahve. Rigdommene kan 
meget vel stamme fra intensiv handelsvirksomhed, som har medført kontakt med fremmede landes handelsfolk. Men de kan desuden vœre et resultat af krigeriske aktioner. En konge som Uzzija gik ifølge 2 Krøn 26,1-15 i krig med filistrene, som han besejrede, og det fortclles, at han modtog tribut fra ammonitterne. Han havde en stor hcerstyrke under sig udstyret med skjolde, lanser, hjelme, brynjer, buer og slyngesten og havde et stort ry. Alt dette skyldtes, at han var under Guds velsignelse (se v. 6). Men da magten steg ham til hovedet, og han blev hovmodig, så gik det galt for ham, og han blev ramt af spedalskhed, 2 Krøn 26,16-23.

Fortclleren gør i 2 Krøn 26,22 opmcerksom på, at hvis vi vil vide mere om denne Uzzija, så er der skrevet om ham i profeten Jesajas Bog. Uzzija er da også ncevnt i Jes 1,1 og 6,1 i dateringerne, men der fortclles ikke direkte om ham. Alligevel må man sige, at hovmodstemaet i Jes 2 passer fortrœeffeligt til, hvad der i 2 Krønikebog fortclles om Uzzijas hovmod og fald.

At det er hestene, der ncevnes, skyldes, at de anvendes foran stridsvogne i krig og er tegn på magt, Ex 15,1.19; SI 20,8; Jes 31,1, men dermed kan de også forlede kongen og folket til at tro, at det er ved egen magt, de vinder krigen (jf. beretningen i Dom 7 om Gideons sejr over midjanitterne, hvor han netop skal sejre med få mand, for at Israel ikke selv skal tage œren af sejren, Dom 7,2).

Kritikken af afgudsdyrkelsen i v. 8 falder inden for samme tema: Det er hovmod og selvovervurdering at dyrke nogle guder, man selv har lavet. Afguderne omtales som אלילים, der kan overscettes ved intetheder, og som tydeligt udtrykker, hvad de er vard. אלילים minder om glosen for Gud, אל המים, hvorved der opstår et underfundigt spil på, hvad de selv tror, at de er, og hvad de i virkeligheden er. At dyrke andre guder strider mod den grundlœggende tanke i Det Gamle Testamente, at Jahve er den eneste Gud for Israel (jf. trosbekendelsen i Deut 6,4). Jahve har udvalgt sig Israel, derfor skal de dyrke ham alene. Dertil kommer et forbud mod at lave gudebilleder og dyrke dem, billedforbuddet, Ex 20,4-6. Afvisningen af dyrkelse af andre guder medfører ikke automatisk en benœegtelse af, at der findes andre guder, men de betragtes som magtesløse. Der er derfor ikke tale om egentlig monoteisme, men om monolatri (se nœrmere i Holt og Nielsen 1999, 72-73).

Mens versene 6-8 har drejet sig om Jahve og folket, er v. 9 formuleret som et generelt udsagn om mennesket. Dette tyder på, at der er tale om en visdomssentens, som her kan bruges som sammenfatning af, hvordan det skal gå den hovmodige. Ved at bruge en generel sentens kan argumentationen styrkes, så man forstår, at der er tale om generelle vilkår i denne verden. Da den klassiske visdom hœvder, at verden er en ordnet verden, hvor enhver får, hvad han eller hun har fortjent, vil menneskers forsøg på at gøre sig til af noget, de ikke er, føre til, at de i deres hovmod bliver 
ydmyget. Sentensen kombineres her med en opfordring til Jahve om ikke at cendre på denne orden ved at tilgive dem. Dette forudsctter, at Jahve er herre også over den gœeldende orden, hvilket svarer godt til Jesajabogens skildring af Jahve som den suverœne herre over hele verden.

\section{0-11}

Med v. 10 opfordres de anklagede til at skjule sig for Jahve, der her er skildret som den vœldige og skrcemmende. At mødet med Jahve er angstfremkaldende fremgår også af Jes 6,5, hvor profeten reagerer med angst på teofanien. Indholdet af v. 10 gentages i v. 21, hvor det siges ligeud, at Jahve rejser sig for at skrœmme verden. I den jesajanske sammenhœeng er der god grund til at reagere med rœdsel, da folket har forbrudt sig mod sin Gud og nu må regne med at få den straf, som allerede er forudgrebet i Jes 2,6: folkets forkastelse. Med v. 11 gentages motivet med menneskets ydmygelse; men hvor det i v. 9 ikke siges direkte, at det er på grund af hovmodet, tales der her om det stolte blik og hovmodet. Som kontrast hertil står Jahve som den, der alene er ophøjet (jf. ophøjelsen af Jahves bolig, Zion, i Jes 2,2). Gud og menneske er ikke ens. Lœst i forlcengelse af afsnittet om afguderne står Jahves ophøjethed også som en modscetning til de magtesløse afguder. Til udtrykket "på den dag" henvises til faktaboksen om Jahves dag s. 78.

Det er hovedindholdet af sentensen i v. 9, der videreføres i v. $11 \mathrm{og}$ v. 17. Gentagelsen af centrale ord har som funktion at forbinde v. 12-17 med det foregående. De i v. 12 og 17 karakteristiske gloser יום יהוה , יום og forekommer således også i v. 11. Den orden, gloserne forekommer i, er ens i v. 11 og v. 17, mens de kommer i omvendt orden i v. 12. Derved skabes der en kiasme, en ABBA form, mellem v. 11 og v. 12, hvilket knytter de to vers sammen.

\section{2-17}

Afsnittet er formet som en trussel (se nœrmere i Kirsten Nielsen 1985, 257-271). Det har som hovedemne Jahves scerlige dag mod alle hovmodige og fortscetter dermed hovmodstemaet. Den tanke, at Jahve har en scrlig dag, findes flere steder i Det Gamle Testamente. Som oftest er der, som her, tale om en ulykkesdag. I Jes 13,9 er det Babylon, der skal rammes, mens det i Jes 34,8 er Edom. Det er en vredesdag, Ez 7,19, og ødelceggelsen af Jerusalem tolkes i Klagesangene netop sådan, Klages 2,22. Af Am 5,18-27 fremgår det, at nogle har forventet, at Jahves dag altid ville ramme fjenderne og derfor betyde sejr og glœde for Israel. Amos advarer og truer med, at det tvœrtimod bliver en mørkets dag. De skal derfor ikke lœnges efter Jahves dag. 
Motivet tages op i Jes 4, hvor dagen ganske vist omtales positivt, men forud for denne scrlige dag gik straffen over folket, så kun en rest skal opleve den positive fremtid under Jahves beskyttelse. Dommen over folket selv er uundgåelig ifølge Jesajabogen, og i Jes 2,12-17 rammer den specielt alle hovmodige mennesker og alt, hvad der omgiver dem af højt.

Ulykken fra Jahve er skildret i billedet af et valdigt stormvejr. At Jahves tilsynekomst, teofani, er forbundet med voldsomme naturfcenomener, er velkendt fra Davids Salmer. I SI 18 griber Jahve ind og redder kongen, men salmedigteren nøjes ikke med at skildre, hvordan Jahve rœkker sin hånd ud og redder kongen op fra de vœldige vande (et billede på nøden), SI 18,17. Selve tilsynekomsten får naturen til at reagere voldsomt. Religionshistorisk set er det forestillinger om en stormgud, der ligger bag, men formålet er at beskrive Jahves magt. Det samme galder SI 29, som Jes 2,12-17 minder en del om. Også her er det naturen, der viser Jahves magt og tilstedevœrelse. Ligesom Jahve er herre over naturen, er han herre over de mennesker, som han i SI 29 er konge for.

De mange eksempler på, hvordan det, der i den menneskelige verden betragtes som stort og valdigt, skal rammes på Jahves dag, har som funktion at understrege Jahves magt. Og med betegnelserne stolt, hovmodigt og knejsende knyttes der til ved hovmodstemaet (jf. brugen af de samme gloser i v. 9 og v. 11 og i v. 12-17). Det siges ikke direkte, hvad der skal ske med de høje trœer, de store bjerge, høje tårne og stejle mure eller med de store fartøjer. Men som det også i andre sammenhœenge gœelder for trusler, bliver de ikke mindre effektfulde af, at det ikke siges direkte, hvori straffen vil bestå. Eksemplerne er hentet dels fra naturens verden dels fra kulturens verden.

Der er tale om billedsprog, der på forskellig vis skal angive, hvordan hovmod står for fald. En bogstavelig lœesning ville dårligt give mening. For hvad har trœerne på Libanon gjort rent bogstaveligt, som skulle kunne begrunde ødelœggelsen af dem? Jesaja har da også en tydelig forkœrlighed for at bruge trœer som billeder, Jes 1,29-31; 4,2-6; 5,1-7; 6,12-13; 9,7-20; 10,16-19; 10,33-11,1; 14,4b-20; 27,2-6; 32,15-20; 37,22b-32, hvilket også er tilfceldet her. I Det Gamle Testamente har Libanon og Basan positive konnotationer, da de er kendt for deres frugtbarhed, fx SI 92, 13; Højs 4,8; Jes 33,9; Ez 39,18 og Mi 7,14. Trœerne på Libanon omtales desuden i Jes 10,34, hvor der ikke er tale om trœfœeldning i bogstavelig forstand, men om et billede på nedkcmpning af storkongen som en forudscetning for, at der igen skal skyde en spire frem af Isajs rod, Jes 11,1 (se nœrmere i kommentaren til Jes 11,1).

Også her i kap. 2 er det derfor muligt at se Libanons trœer som billede på magthaverne, der betragter sig selv som lige så vœrdifulde som de Libanoncedre, som blev anvendt til bygningen af 
Salomos tempel, 1 Kong 5,20; 1 Kong 6,15, og Salomos palads, 1 Kong 7, 1-12. I Targum, den aramaiske gengivelse af den hebraiske tekst, gengives "alle Libanons trcer" i Jes 2,13 ved "alle folkenes stcrke og magtige konger". Her er der ingen tvivl om, at stedet er blevet tolket billedligt om de politiske ledere, hvilket svarer godt til det jesajanske budskab i øvrigt.

At truslen angår de høje bjerge kan tolkes ud fra kritikken af afgudsdyrkelse, da bjergtoppe forbindes med dyrkelse af afguder, Deut 12,2. Høje tårne er udtryk for menneskelig strceben, sådan som det tydeligt illustreres gennem fortcllingen om Babelstårnet, Gen 11,1-9, og de stejle mure er menneskelige forsøg på at skaffe sig sikkerhed mod fjender. En kontrast hertil er fx Salmistens billeder af Gud som "min klippe, min borg, min befrier, min Gud, mit bjerg, hvor jeg søger tilflugt, mit skjold, min frelses horn og min fœestning", SI 18,3.

Tarshish-skibene kan vœre skibe, der ligger ved Elat. I 1 Kong 22,49 nœevnes bygning af et Tarshish-skib m.h.p. guldtransport! Der bliver dermed skabt en forbindelse tilbage til Jes 2,7 med kritikken af det meget sølv og guld, som de har samlet sig. Både den last, de medbringer, og skibenes egen pragt stemples som hovmod. Herefter gentager v. 17 stort set v. 11, og dermed dannes der en cirkelkonstruktion. Når et digt begynder og slutter på samme måde, skabes der en afrundet helhed, hvor begyndelse og afslutning angiver hovedtemaet.

18

Med v. 18 genoptages motivet med udryddelsen af afguderne fra v. 8. Hvad der var højdepunktet af frafald i afsnittet v. 6-9 og begrundelsen for ydmygelsen af de hovmodige, afslutter her truslerne mod dem i v. 12-17.

\section{9}

Også dette vers er en genoptagelse af et tidligere motiv, nemlig v. 10. Efter udryddelsen af afguderne kommer turen til deres dyrkere, som har al god grund til at frygte Jahve og hans magt. Netop Jahves styrke står som modsctning til de magtesløse afguder, som ifølge v. 8 er menneskeskabte. Hvor v. 8 kun omtaler Jahves storhed og menneskers frygt for Jahve, uddybes motivet her med angivelsen af formålet med Jahves tilsynekomst: Han rejser sig for at skrœmme jorden. At Jahve skaber rœdsel, פחד, er et motiv, der er forbundet med den hellige krig, hvor guddommen ved sin tilsynekomst får alle fjenderne til at skœlve og flygte i rœdsel, Deut 2,25; Deut 11,25. 


\section{0-21}

Ordene om folkets forkastelse af afguderne viderefører kritikken mod afguderne i v. 8 og truslen mod dem i v. 18 ved at prcecisere, at det er dem, der dyrker disse afguder, der selv skal forkaste dem ved at smide dem ud til spidsmus og flagermus. Muligvis ncevnes flagermusene, fordi de er urene, Lev 11,19 og Deut 14,18. Under alle omstcendigheder ligger der en hån i, at de fjernes fra menneskeverdenen og forvises til dyreverdenen. Med v. 21 gentages opfordringen fra v. 19 i form af en beskrivelse af, hvordan menneskene skal skjule sig i radsel for Jahve.

\section{2}

Kapitlet slutter med endnu en visdomssentens, der advarer mod, at man sctter sin lid til mennesker. Begrundelsen er overraskende: Mennesket har נשמה i ncesen, og derfor er det ikke vœrd at regne. Set i lyset af Gen 2,7, hvor den נשמת חיים, som Gud indblceser i mennesket, er et positivt element (se også Jes 42,5), lœgger sentensen vœgten et andet sted. Denne livsånde har sin begrcensning. Det er kun en vis tid, mennesket trœkker vejret. Visdomssentensen må forventes kendt af lœserne, som på grund af det almene i påstanden lader sig overbevise om, at så galder det også alle dem, kapitlet i $\varnothing$ vrigt har rettet anklager og trusler imod. De er heller ikke bedre vœrd!

Tilbage til indholdsfortegnelsen

\section{Jes 3,1-15}

\section{Tekstkritik}

$8 \mathrm{~b}$

עני foreslås af nogle forskere slettet, mens andre retter til עם. Verbet מרה forbindes normalt med prcepositionen ב, når det betyder at vœere genstridig mod nogen, Hos 14,1 og SI 5,1 1. Uanset, hvordan man valger at rette i teksten, er der dog enighed om betydningen: vare genstridig imod.

$10 a$

אמר og er en opfordring til at sige noget. I sammenhcengen giver det dårlig mening, hvorfor der i DO 1992 rettes med BHSa til אשרי, der betyder lykkelig. Et lykke-ønske for den retfœrdige ville modsvare veråbet over den uretfcrdige i v. 11. 


\section{Karakteristik}

Domsforkyndelsen i dette afsnit er indledningsvis vendt mod folkets ledere, som Jahve vil fjerne. I stedet vil Jahve give dem ledere, som endnu kun er drenge og derfor ikke magter den opgave at skabe ro i landet. Resultatet er borgerkrig, alles kamp mod alle. Tematisk er der en forbindelse tilbage til det foregående kapitel, hvor alt det høje skal ydmyges. I Jes 3 fjernes ledelsen og erstattes af personer, der normalt netop ikke udpeges til ledere, drenge, v. 4, og kvinder, v. 12. Gennem en modstilling af den retfœrdige og den uretfœrdige og deres forskellige skcbner, v. 10-11, understreges den retfcerdige sammenhœeng i Jahves styre. På baggrund af domsoraklerne følger en retsscene, der slutter uden kendelse som et åbent spørgsmål til de anklagede ledere, v. 13-15.

Afsnittets indledende beskrivelse af et samfund i opløsning giver samtidig en tolkning af, hvorfor det sker. Det er Jahve selv, der bringer ødelœggelse over sit folk. Og grunden er folkets oprør mod Jahve. Ved hjœelp af de to sentenser, v. 10-11, prœciseres de fra den klassiske visdom velkendte regler for tilvœrelsen: Den retfœerdige går det godt, mens det går den uretfœrdige ilde. Hermed argumenteres der for retfœrdigheden i Jahves handlinger, når han straffer de uretfcrdige. Også den ufuldstcendige retssag fungerer som dokumentation for berettigelsen af Jahves dom over de uretfœrdige ledere.

Teksten består af oprindeligt selvstcendige udsagn, som nu er føjet sammen til en lœngere tale med et fœelles tema. Det er nœppe muligt at datere Jes 3,1-15, da skildringen er holdt i meget generelle vendinger. Indholdsmœssigt passer afsnittet godt ind i den jesajanske forkyndelse. De meget generelle udsagn har desuden gjort forkyndelsen aktuel ikke blot i 8. årh. f.Kr., men også som beskrivelse af situationen efter Jerusalems ødelœggelse i 587 f.Kr.

\section{Struktur}

1-9a Domsudsagn mod folkets ledere og landets indbyggere p.g.a. af deres oprør mod Jahve.

9b-11 Veråb over de uretfœrdige og lykke-ønske for den retfœrdige.

12 Advarsel til folket om dets dårlige ledere.

13-15 Retsscene: Anklage mod de celdste for mishandling af de svage. 


\section{Fortolkning}

$1-9 a$

Kapitlet begynder med at pege direkte på Jahve som herren, האדון, og som צבאות, יהוה, hcerskarers Jahve. Med opmcrksomhedspartiklen הנה spores lceseren ind på, hvem det er, man skal fokusere på i det følgende, og det følgende participium angiver da også, at det er Jahve, der er den aktive. At Jahve er herre implicerer, at der er undergivne, og det prœciseres i det følgende, at han er hcerskarernes Jahve. Udtrykket יהוה צבאות er iscer forbundet med de forestillinger, man gjorde sig om Jahve som krigsherre, Jes 1,24. Det anvendes i beretningerne om pagtens ark, der under kampen med filistrene bringes til Silo, så den kan drage ud sammen med hœeren. Her hedder det, at Haerskarers Jahve troner på keruberne, 1 Sam 4,4. Herredømmet over hœrskarerne omfatter også de himmelske hcere, som Jahve ifølge Jes 13,4 også mønstrer i kampen mod Babylon. Ifølge Jes 6,5 har profeten endda set kongen, Hœrskarers Jahve, i Jerusalems tempel, og også Jes 37,32 viser, at dette tilnavn har vœret knyttet til Jerusalem (se også Jes 25,6 og Zak 14,16-17). Det er således Jahve som den guddommelige kriger med det altomfattende herredømme, der prœsenteres i Jes 3,1.

Krigertemaet belyser de handlinger, der beskrives i det følgende. Når Jahve fjerner støtte og stav fra Jerusalem og Juda betyder det, at han netop ikke vil optrcede som den guddommelige kriger, der kœmper for at hjœlpe sit folk. De to betegnelser for støtte og stav, משענה og משען, skaber associationer til den stav, en fyrste bcerer, Num 21,18, eller til hyrdens stav, SI 23,4. Både fyrsten og hyrden har ansvar for den flok, de skal lede. Men nu tager Jahve den støtte fra dem, som deres ledere var ansvarlig for, og som folket var afhcengigt af (jf. også Jes 10,20, hvor det er assyrerkongen, som de ikke lœngere skal støtte sig til, samt Jes 31,1, hvor de anklages for at støtte sig til Egypten og de mange heste i stedet for Jahve).

Den støtte, Jahve fjerner, omfatter nœsten alt, hvad der hører til et samfund. Brød og vand er de helt basale levnedsmidler og angiver sammenfattende "det daglige brød". For at kunne overleve krœves der dog mere end føden. Samfundet skal beskyttes mod ydre fjender, derfor nœvnes i v. 2 de professionelle soldater, helte og krigere. I forlœngelse heraf opregnes fire grupper af personer, som på forskellig vis har med samfundslivet at gøre. En dommer, שופט, er en embedsmand, måske med tilknytning til hoffet, som skal sikre ret og retfœerdighed i samfundet, så det ikke går i opløsning, og den stcrke undertrykker den svage. En profet, נביא, er kaldet til at viderebringe Jahves ord. Ordet kan både forstås aktivt som en der kalder, eller passivt som en, der er kaldet. Profeten skal videregive, hvad Jahve har besluttet. Profeten kan både forkynde dom og frelse og kan på den måde op- 
trcede som rådgiver i samfundet. Ordet bruges i Det Gamle Testamente både om sande og falske profeter. Det er ikke til at afgøre, om der i dette tilfclde er tale om profeter knyttet til hoffet (jf. at konger omgiver sig med profeter, fx 1 Kong 22,6), det vaesentlige er, at når de fjernes, brydes forbindelsen til Jahve.

Spåmanden, sop, har indsigt i fremtiden og har dermed en vigtig funktion i samfundet, når der skal planlœgges for fremtiden. Parallelt med spåmanden nœvnes den, som er œeldste, ז og derfor kan rådgive ud fra sin erfaring om fortiden. I stammesamfund er slagtens celdste også dens ledere.

Med v. 3 genoptages krigertemaet. Delingsføreren er en, der er fyrste over 50 mand, שריחמשים, og dermed har en lederpost i militœret. Den ansete hedder på hebraisk en med løftet ansigt, נשוא פנים. Der er muligvis tale om et embede med taet tilknytning til kongen (jf. 2 Kong 5, 1, hvor aramceerkongens hcerfører Na'aman betegnes på den måde). I hvert fald er der tale om en, der er begunstiget med sin overordnedes velvilje og derfor nyder respekt. Rådsherren, יועץ, er en rådgiver for kongen (jf. 2 Sam 15,12, hvor Akitofel omtales som Davids rådgiver). Den trolddomskyndige, חכם חרשים, og slangebesvœrgeren, נבון לחש, hører til den mere uofficielle del af samfundet, men har uden tvivl varet vœerdsat for deres evner til at fremsœtte besvœrgelser og dermed bringe ulykke over ens fjender (se fx Jer 8,17 og SI 58,6 om besvœrgelse af slanger).

Listen over samfundsstøtter, som nu skal fjernes, virker omfattende; men det er karakteristisk, at hverken kongen eller prœsterne nœvnes her. Dette kan skyldes, at Jesajas håb om en rest, der trods alt skal reddes, bl.a. omfatter disse grupper (se ncermere om synet på Davidsslcegten s. 79).

Med v. 4 angives som kontrast til det ordnede samfund, hvor lederne er sig deres ansvar voksent, et samfund, hvor det er drenge, der står i spidsen. I datidens samfund var erfaring og dermed alder en forudscetning for lederskab, herunder erfaring og styrke nok til at gå i krig (se fx 1 Sam 17,33 om David, der som ung dreng vil kœmpe mod Goliat). Den tanke at scette unge drenge til at styre er grotesk. Ud af et sådant lederskab kan der kun komme politisk og socialt kaos og anarki. Drengene betegnes desuden som lømler, תעלולים. Ordet kommer af roden עלל I, der i hitpael betegner at stille sig modvillig an. Af den slags kan man ikke engang forvente, at de lader sig belcere af mere erfarne folk. Ud fra et sted som dette vil nogle forskere forsøge at finde tidspunkter i Judas historie, hvor ganske unge maend kom til magten. Men udtrykket drenge kan også bruges til at karakterisere det barnagtige ved lederne - uanset alder. 
Konsekvensen udmales i v. 5, hvor borgerkrigen beskrives. Alle kcemper mod alle. De unge har ikke respekt for de gamle. Underklassen, de ringeagtede, respekterer ikke lœngere overklassen, de fornemme. Det hierarkisk opbyggede samfund, der blev betragtet som en garant for orden og stabilitet, går totalt i opløsning. De gœeldende vœrdier vendes på hovedet. Verbet רהב, der kan gengives ved at sctte sig op imod, kan give associationer til drageuhyret, רהב, der i Det Gamle Testamente netop er reprcesentant for det kaotiske, Job 26,12 og SI 89,1 1. Urhavet og de store uhyrer, der findes der, kan netop bruges som billeder på de magter, der gør oprør mod Jahve og derfor må nedkcempes (SI Jes 51,9).

I v. 6 gives et situationsbillede, der skal vise, hvor håbløs situationen er under en borgerkrig. Kriteriet for at blive udpeget til leder er nu blot det at eje en kappe og dermed kunne se ud som en person med en vis myndighed. Samtidig gøres det klart, at hvad der er tilbage at vœre hersker over, ikke er andet end en ruin, המכשלה, en allerede sammenstyrtet bygning. Opfordringen afvises da også straks, v. 7. Begrundelsen er todelt. For det første vil han, der opfordres til at blive leder, ikke forbinde sår. Verbet חבש anvendes bl.a. i Ez 34, hvor profeten skildrer hyrdens rolle over for hjorden. Hertil hører at forbinde de sårede, Ez 34,4.16. Hyrdebilledet anvendes i Ez 34 om Israels ledere, og det at forbinde de kvœstede får skal naturligvis forstås billedligt som det at tage sig af dem, der på den ene eller anden måde lider nød. På samme måde skal afvisningen i Jes 3,7 forstås. Den adspurgte vil ikke vœre fyrste over sit folk.

For det andet mangler han både brød (jf. at Jahve vil fjerne brødet, v. 1) og kappe. Han vil derfor ikke kunne påtage sig det ansvar, der følger med at vœre folkets fyrste. Han har hverken de materielle midler eller det vœrdighedstegn, der ligger i kappen. Med til forestillingerne om den rette ledelse hører i Det Gamle Testamente, at en konge skal redde den fattige, forbarme sig over de svage og udfri dem, der undertrykkes og udscettes for vold, SI 72,12-14.

Vers 8 giver begrundelsen for, at Jerusalem og Juda skal opleve dette sammenbrud. Verbet כשל skaber en forbindelse tilbage til v. 6, hvor landet skildres som en ruin, המכשלה. Alt falder sammen omkring dem. Og årsagen skal findes i deres forhold til Jahve. Både deres tunger, dvs. deres tale, og deres handlinger er prœget af genstridighed. Verbet מרה brugtes i Jes 1,20 i den korte retsscene, hvor konsekvensen af at vœre genstridige er klar: De skal fortceres af svœrdet. Nu gentages verbet $\mathrm{i}$ et domsorakel, og indirekte siges dermed, at de har handlet således, at de må stilles for retten, og dér vil de blive kendt skyldige. At vise genstridighed med sin tunge kan betyde at tale løgn (jf. Jes 59,3, 
hvor hœenderne er sølet til af blod, lœberne taler løgn, og tungen forkynder ondskab, samt Jer 9,7, hvor tungen beskrives som en drœbende pil).

Jahves herlighed, בבוד, betegner Jahve som den hellige omgivet af stråleglans og bruges ofte i forbindelse med teofaniskildringer, SI 29,9; 97,6 og Jes 6,3. Den forventelige reaktion på mødet med Jahves herlighed er œrefrygt. At de er genstridige betyder, at de afviser at forholde sig til Jahve, som man bør, nemlig ved i crefrygt at adlyde hans vilje.

Ikke blot tungen og handlingerne, men også ansigtet afslører dem, v. 9a. Verbet ענה kan bruges om at vidne mod nogen, Jer 14,7, og det kan på den måde angive det rettergangsmotiv, som så ofte skinner igennem i Jesajabogen, og som er med til at understrege Jahves retfcrdighed, når han straffer sit folk. Man forventer normalt ikke, at en skyldig åbenlyst praler af sine overtrœdelser, men det er netop tilfœldet med indbyggerne i Juda. De forsøger ikke at skjule noget, men fortœeller om deres synd. Til sammenligning nœvnes ganske kort Sodoma. Sammenligningen må gå på deres syndighed, idet netop Sodoma ifølge gammeltestamentlig tradition kan stå som et af hovedeksemplerne på syndige mennesker (jf. Gen 19 og den lidet respektfulde modtagelse, Jahves to engle bliver mødt med).

\section{$9 b-11$}

Med v. 9b begynder et nyt afsnit. Der anvendes to velkendte Gattungen: veråbet og lykke-ønsket.

\section{Faktaboks: Veråb og lykke-ønsket}

Veråbet er en velkendt taleform inden for den profetiske anklage. Det bruges til at udtrykke smerte, vrede og sorg. Det kan signalere, at det er ude med dem, der råbes ve over. I Jes 1,4 og 1,24 indledes veråbet med glosen הוי (se også Jes 5,8.11.18.20.21.22; 10,1.5), mens det i Jes 3,9 er det tilsvarende ord אוי, som desuden gentages i v. 11 (se også Jes 6,5). Tankegangen minder om visdomsteologien med dens påpegning af, at det vil gå den onde ondt, SI 1,5-6.

Modsctningen til veråbet er lykke-ønsket. Det kendes fra visdomslitteraturen, SI 1,1 og 2,12, og understreger sammenhœengen i tilvœrelsen, hvor det går den retfœrdige godt. I visdomslitteraturen kan der komme noget nœsten selvfølgeligt over denne sammenhœeng mellem årsag og virkning. Lœst i forlœngelse af Jes 3,1-9a vil overskriften dog vœre, at det er Jahve, der har besluttet sig for at straffe sit genstridige folk. Det er derfor også Jahve, der sikrer, at den retfœrdige får et godt liv (jf. SI 128,2). Hvad det gode liv indebcerer, fremgår af den skildring af henholdsvis forbandelsen og velsignelsen, der findes i Deut 27,12-30,20. Heraf fremgår, at det er en forbandelse ikke at kunne nyde frugten af jorden eller udbyttet af ens eget slid, men at måtte opleve, at det er fjenderne, der 
får gavn af ens indsats, Deut 28,33. Når indsats og resultat ikke hœenger sammen, så er velsignelsen borte, og forbandelsen hersker.

I Jes 3,9 er ulykken uundgåelig, for de bringer den selv med sig. Modstillingen af den retfœrdige og den uretfœrdige, v. 10-11, er et hyppigt anvendt pœedagogisk middel i visdomslitteraturen. Tilvœrelsen bliver på den måde overskuelig, og valget mellem ret og uret fremstår som klart og entydigt. At der er sammenhceng mellem indsats og udbytte fremgår også af ordspillet i formuleringen i v. 11.

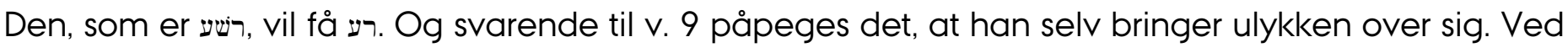
at bruge formuleringer, der svarer til den klassiske visdom, og dermed har ordsprogskarakter, kan forfatteren til Jes 3,10-11, udnytte den almene forhåndsviden, som netop ordsprog er udtryk for (jf. fx Ordspr 12,26: "Den retfœrdige udsøger sin grœsgang, uretfœerdiges vej leder dem vild"; se også Ordspr 10,3).

\section{2}

Med dette vers gribes der tilbage til temaet fra v. 4: de dårlige ledere. Det er Jahve, der henvender sig til sit folk og anklager det for at have dårlige ledere. Ikke alene er det et barn, der står for styret, men også kvinder. Det er de marginaliserede grupper, der pludselig er kommet til magten, og en sådan omvœeltning af gœeldende orden er ikke af det gode, forstår man. Forskerne har forsøgt at finde et eksempel fra 8. århundrede f.Kr. på, at et barn kommer på tronen. Det gaelder dog hverken for Jotam eller Akaz, men kunne eventuelt passe på Hizkija, der ifølge 2 Kong 18,2 var 25 år, da han blev konge, hvilket trods alt var en forholdsvis ung alder. Spørgsmålet er dog, om der tcenkes bogstaveligt på børn og kvinder, eller det ikke snarere er billedsprog for magtesløse og uerfarne ledere. Ofte er man under lœsningen af Jesajabogen i tvivl om, hvorvidt et udtryk skal forstås bogstaveligt eller billedligt, da en sådan tvetydighed er en af de mange finesser ved den jesajanske forkyndelse. Lœst i sammenhœengen her giver det dog bedst mening at forstå omtalen af børn og kvinder billedligt om de uegnede. Det er i hvert fald det, som er pointen i resten af verset: De er dårlige vejledere, der gør det modsatte af, hvad de skal. De leder vild i stedet for at føre dem ad de rette stier, ja de forvirrer endda den vej, folket skulle følge, så den bliver et vildspor. Vejen er her, som så ofte i Det Gamle Testamente, et billede på menneskers livsførelse. 


\section{3-15}

Første halvdel af Jes 3 slutter med en retsscene (se ncermere i Kirsten Nielsen 1977, 75-79). Ligesom i de to andre retsscener, Jes 1,2-3 og 1,18-20, har Jahve rollen som anklager, ligesom det er ham, der skal afgive den afsluttende kendelse: skyldig eller ikke skyldig. Retsscenen indledes med, at Jahve trœder frem. En tilsvarende beskrivelse findes i SI 82,1, hvor Gud trceder frem i gudernes forsamling. I salmen er formålet at fœelde dom over guderne, der alt for lœnge har optrådt som uretfœrdige dommere, der ikke har skaffet de svage deres ret. I Jes 3,13 er formålet angivet med verbet ריב og med verbet דין. Det første verbum har givet navn til den tekniske betegnelse, Rîb-Pattern (jf. s. 16-17).

Den korte retstale indeholder da også nogle af de elementer, som Julien Harvey betragtede som forholdsvis stabile i Rîb-Pattern: 1) forberedelserne til processen 2) forhør uden forventning om svar og 3) anklagetale. Derimod er der ingen officiel erklœring om anklagedes skyld og heller ingen trusler eller befalinger om, hvordan de anklagede skal forholde sig. Når det alligevel er afklarende at inddrage Harveys iagttagelser, skyldes det, at det følgende orakel, Jes 3,16-4,1, i den nuvœrende komposition har som funktion at uddybe retssagen, dels ved at udvide gruppen af anklagede til også at omfatte kvinderne dels ved at udstede den trussel, man kunne forvente ud fra Rîb-Pattern. Jes 3,13-15 er et selvstcendigt orakel, der i første omgang må tolkes uden hensyntagen til de følgende vers. Men på det redaktionelle plan skal den korte retsscene lœeses som indledning til det følgende.

Jahves rolle er både anklagerens og dommerens. Han vil føre retssag, ריב, og han vil dømme, דין. At Jahve trceder frem, dvs. står op, tyder på, at han nu påtager sig rollen som anklager; dommeren sidder normalt ned, Ex 18,13; Ordspr 20,8; SI 122,5; Dan 7,9-10. Verbet דין bruges derimod nasten altid om dommeren, Gen 15,14; SI 72,2; Ordspr 31,9; Jer 21,12.

Det er påfaldende, at de anklagede omtales i flertal som עמים og ikke i ental. LXX har entalsformen, og det foreslås da også i det tekstkritiske apparat, at der rettes til ental, עמו (jf. SI 50,4). Men da teksten er forståelig i sin nuvœrende form, bør man nceppe gribe til rettelser. Hvis man lagger vœegten på, at v. 13 beskriver Jahves rolle, vil flertalsformen markere hans magt til at fœlde dom over alle folk. Flertalsformen vil give indtryk af, at nu vil Jahve dømme Israels fjender (jf. strategien i Jes 5,1-7, hvor tilhørerne også begynder med at tro, at det handler om "de andre"). Det er storherren, der viser sig, og som derefter henvender sig specifikt til de celdste og stormcendene i det folk, der kaldes hans eget.

I v. 14 er det igen først Jahves rolle, der beskrives. Udtrykket יהוה במשפט יבוא kan bruges om både anklager og dommer. Herefter fokuseres der på, hvem de anklagede er: folkets celdste og 
stormœnd. Igen er det ledelsen i Juda, der står under anklage. Anklagen formuleres klart som en anklage for magtmisbrug. Billedet af vingården (se ncermere ovenfor s. 12-14 samt kommentaren til Jes 5,1-7) er brugt om folket. En vingård står i fare for at blive gnavet ned af vilde dyr, hvis ikke vingårdsejeren sørger for at bevogte den, Jes 5,2, og indhegne den, Jes 5,5. I billedet her sker ødelœggelsen indefra. Det er dem, der har ansvaret for vingården, der selv ødeløegger den ved som vilde dyr at gnave den ned. Der er tale om udsugning af de fattige, og beviset for forbrydelserne ligger hjemme hos de anklagede. Hvad de har tilranet sig, det kan nu findes i deres egne huse (se også Jes 5,8 og 10,2).

Efter anklagen kommer et kort forhør, hvor Jahve spørger dem, hvorfor de har handlet sådan? Nu er det ikke billedet af vingården, men et andet billede fra hverdagslivet, der anvendes. Billedet er hentet fra arbejdet med at kvœrne korn mellem kvœrnstenene. De enkelte korn skal knuses og males til mel. Formuleringerne minder om Ordspr 22,22-23: "Du må ikke røve fra den svage, fordi han er svag, du må ikke knuse den hjcelpeløse i porten; for Herren fører deres sag og berøver deres røvere livet." Dette kan tolkes sådan, at profeten anvender nogle velkendte udtryk og dermed forstcrker anklagen. Alle og enhver ved jo, at det strider mod Jahves vilje at handle sådan. At forhøret foretages af Jahve selv fremgår af de sidste ord i v. 15, hvor Jahve omtales som den talende og ncevnes som Herren, Hœrskarers Jahve (jf. v. 1). Der står magt bag retssagen!

Den korte retsscene begynder med en beskrivelse af Jahves komme til dom og slutter med en understregning af, at det er ham, der anklager og forhører de anklagede. Som moderne lceser sidder man og venter på yderligere nogle led. Hvad vil de anklagede sige til deres forsvar? Og hvad vil dommeren sige? Et af de karakteristiske trœk ved de profetiske retstaler er dog, som tidligere ncevnt, at der aldrig forekommer noget forsvar. De anklagede tager ikke til orde, hvilket må ses som udtryk for, at de ikke har noget at sige. De er skyldige, og der findes ikke nogen formildende omstcendigheder at pukke på.

Det manglende forsvar er ikke udtryk for, at man i gammeltestamentlig sammenhang altid forestiller sig en retssag som enetaler holdt af henholdsvis anklageren og dommeren. Både i Syndefaldsberetningen, Gen 3, og i fortcellingen om Kain og Abel, Gen 4, der begge er struktureret som retssager, tager den anklagede til orde og forsvarer sig. Adam forsvarer sig med en modanklage mod Gud, der har givet ham kvinden, som fristede ham til at spise af frugten, Gen 3,12. Og Kain afviser anklagen ved at hœvde, at han ikke er sat til at vœre vogter for sin bror, Gen 4,9. 
Ud over at der ikke følger noget forsvar, må man som lœser også savne dommerens vurdering af sagen, hvad enten dommeren vil udstede trusler om kommende straf eller formane de anklagede om, hvordan de skal forholde sig fremover. Den retoriske effekt af den uafsluttede retssag består i, at nu skal de anklagede selv svare. Man kan ganske vist ikke forestille sig andet svar, end at de må erklœre sig skyldige i magtmisbruget (jf. Jes 3,1-12, der tydeligt angiver, at Jahve vil straffe dem); men det er betydningsfuldt, at de selv bliver nødt til at tage dommen på sig ved at udtale den (jf. 2 Sam 12,5-7, hvor David fœlder dom over sig selv).

Tilbage til indholdsfortegnelsen

\section{Jes $3,16-4,1$}

\section{Tekstkritik}

Der er ingen grund til at rette i teksten.

\section{Karakteristik}

Det følgende afsnit er domsforkyndelse rettet mod kvinderne i Jerusalem. Lœst i forlœngelse af retsscenen i v. 13-15 fungerer afsnittet som en anklage efterfulgt af trusler. Det er Jahve, der fremfører anklagen og truslen om straf på grund af deres hovmod. Hovmodet viser sig ved, at de alene tcenker på deres eget udseende, og på hvordan de kan gøre indtryk på andre. Anklagen svarer til anklagen for hovmod i Jes 2,6-22, men er her rettet specielt mod kvinderne. I v. 18-23 er truslen formet som et katalog over deres smykker og klœeder, som Jahve vil fjerne som straf, mens v. 24 er poetisk formet ligesom v. 16. Der er nceppe tale om en oprindelig enhed, men som teksten står nu, udgør kataloget det bevismateriale, som anklageren fremlaggger.

Mens v. 16-24 henvender sig til byens kvinder, er 3,25-4,1 henvendt til Zion i billedet af en kvinde, der bliver enke og oplever, at der er mangel på mand at gifte sig med. Oraklet mangler en begrundelse for, at mœendene skal falde og Zion klage sig over sin enkestand. Men lœst i den nuvœrende sammenhœng må anklagen mod Jerusalems kvinder ses som den fœlles baggrund for truslerne mod henholdsvis kvinderne og byen. Tematisk hcenger de to afsnit sammen, selv om sprogbrugen œndrer sig fra bogstavelig tale til billedsprog. 


\section{Struktur}

16-24 Anklage og trussel om straf over kvinderne for deres hovmod og pyntesyge.

3,25-4,1 Trussel om straf over Zion: Mœndene skal dø i kamp, og Zion skal sidde tilbage som enke.

\section{Fortolkning}

$16-24$

Oraklet indledes med en prcecisering af, at det er Jahve, der taler, v. 16. På den måde knyttes der til ved den direkte Jahvetale i v. 14-15. På hebraisk indledes oraklet klart begrundende: יען, fordi at, og angiver derfor den anklage, der begrunder truslerne om straf. Udtrykket Zions døtre bruges her om indbyggerne i Jerusalem, der karakteriseres med verbet גבה. Ord af samme rod blev også brugt i Jes 2,11-17 om alt det hovmodige (se v. 15 og v. 17). Det er også hovmod i form af selvoptagethed, der kendetegner deres måde at holde hovedet højt på, mens de ser sig omkring og rasler med de ankelsmykker, der skal tiltrckke sig opmcerksomhed fra dem, de passerer forbi. Omtalen af hovedet og derpå fødderne er en anden måde at markere på, at de er hovmodige fra isse til fodsål, dvs. helt igennem.

Som en konsekvens heraf vil Jahve gør kvinderne skaldede. Straffen rammer i første omgang, hvad kvinderne betragtede som deres scerlige fortrin, det smukke hår. Skaldethed indgår desuden i sørgeritualer, fx Jes 15,2. Skaldetheden kan derfor også ses som et varsel om, at de snart vil have grund til at sørge og klage. Kvinderne straffes desuden ved, at al deres udsmykning tages fra dem. Det lange katalog af smykker og dragter holdt i prosaform, Jes 3,18-23, virker overraskende som del af oraklet. Men funktionen er klar nok: Listen skal understrege anklagen for hovmod.

Ankelringe er lavet af metal og er undertiden også udstyret med små klokker, så de ringler (se v. 16). Soltegn og månetegn kan tolkes som udtryk for, at de også dyrker himmellegemerne og bruger smykker formet som sol og måne som amuletter, der skal beskytte dem. Også dyrkelse af afguder er tegn på hovmod, ligesom det strider mod såvel forbuddet mod at dyrke andre guder som billedforbuddet i Ex 20,4-6. Listen omfatter ud over smykker og amuletter også lugtedåser, dvs. parfumebeholdere, tasker og spejle samt et righoldigt udvalg af tøj. Der er ingen tvivl om, at det er overklassens påklcedning, der her er tale om, og dermed også de ledendes kvinder, der anklages, og som skal straffes for deres hovmod. 
I v. 24 sammenfattes situationen i form af modscetninger. Hvad der var tilfceldet før, skal erstattes af pracis det modsatte. I stedet for den kostbare og duftende balsamsalve, bcelterne, de flotte frisurer og festdragterne skal kvinderne nu omgive sig med stank, de skal bruge reb som bcelte, vœre skaldede og have en sck om livet. Glosen for stank, מק, bruges i SI 38,6 som verbum om stanken fra sår, der vœsker, hvilket kan give indtryk af, at også kroppen skal gå i forfald. De mange fund af hårkamme i det palœstinensiske område viser, hvor stor vagt man har lagt på frisuren. Skaldethed er derfor den totale modsctning. At udseendet generelt har vœret vigtigt fremgår også af omtalen af spejle, fx Ex 38,8. Sckken er også den klœdning, man bruger som tegn på sorg, fx Gen 37,34; 2 Sam 3,31.

Verset slutter overraskende kort med ordene: i stedet for skønhed. I LXX er ordene ganske enkelt ikke gengivet. Oversctteren har formentlig opfattet dem, som om det var en tilføjelse, som ikke hørte rigtigt med til teksten. Men de giver ganske god mening som led i en retorisk strategi. Når det ikke nœvnes, hvad der skal komme i stedet for skønhed, overlades det til laeseren selv at gå ind i tankegangen og udfylde det, der mangler. Samme teknik kendes fra de ufuldstcendige retstaler, Jes 1,2-3; 3,13-15, og fra 7,7-9, hvor lœseren også selv må tœenke sig til, at Juda også har et hoved, Jerusalem, som selv har et hoved, kong Akaz - eller Jahve (se kommentaren til Jes 7,7-9). Formålet er at engagere lœseren, så denne selv drager de nødvendige slutninger og dermed også bliver medansvarlig for dem.

\section{$3,25-4,1$}

Som konsekvens af anklagerne for hovmod skildres nu et scenarie, der viser den straf, der venter kvinderne: Deres mcend skal falde for svœrdet (jf. Jes 1,20). Glosen for mcend, מתים, er forholdsvis sjœldent brugt, men anvendes fx i Deut 2,34 og Deut 3,6 om at løegge band på mœnd, kvinder og børn. Udtrykket er ofte forbundet med hellig krig, hvor det betyder at drœbe dem, der er lagt band på. For set ud fra den hellige krigs ideologi er fjenderne ikke blot folkets fjender, men fjender af Jahve. Nu rammes Jahves eget folk af samme straf og dermed antydes, at de er blevet fjender af Jahve. Da kvindernes luksus er afhœngig af deres œgteskab med velhavende mœnd, hœenger truslerne om at miste al luksus logisk sammen med skildringen af tabet af œgtemcend.

Når en kvinde mister sin mand, efterfølges tabet af en sørgeperiode, v. 26. I dette vers er det Zion selv, der har mistet alting. Samme billedsprog anvendes i Klagesangene, hvor Zion efter babylonernes ødelœggelse af Jerusalem skildres som en sørgende enke. Vejene til Zion sørger, hedder 
det i Klages 1,4, og Zions datter har mistet al sin pragt, Klages 1,6. Urenhed klœber til hendes skørter, Klages 1,9, og Jahve har fremkaldt "suk og stor klage hos Judas datter", Klages 2,5 (både i Jes 3,26 og Klages 2,5 anvendes den sjceldne rod אנה I for klage). I Jes 3,26 sidder Zion på jorden som en sørgende enke (se også Klages 1,1; 2,10), og hendes porte klager og sørger.

Indgangene til byen er de svage steder i tilfœlde af krig. Nu er portene ødelagt, og byen er blottet, så enhver kan gå derind. Zion er ribbet for alt. Glosen נקתה, (nifal af verbet betyder her at vœre tom. Byens indbyggere er fjernet. Billedlig talt er hun som en barnløs enke (jf. Klages 1,1).

Fra billedet af byen som en kvinde vender Jes 4,1 tilbage til byens kvinder. Der er rift om mœndene. For hver enkelt mand er der øjensynlig hele syv kvinder. At vœre enke i datidens samfund var uhyre problematisk. Enker havde ikke arveret efter deres mand (jf. Num 27,7-1 1, hvor døtre i sœrlige tilfclde får arveret, men enker nœvnes ikke i arvelovene). Gennem loven om svogercgteskab, Deut 25,5-10, var der skabt mulighed for nyt œgteskab. Men i den situation, hvor der kun er få mœnd, er det nœppe aktuelt at forestille sig, at svogerœgteskaber kan løse problemet. Har kvinden sønner, skal sønnerne tage sig af hende, ellers må hun vende tilbage til sin fars hus. I Jes 3,26 synes ingen af de nœvnte muligheder at vœre aktuelle. Kvinderne griber blot panisk ud efter en mand, hvis navn de kan bœre, dvs. blive gift med.

Kvinderne lover desuden at give afkald på to tredjedel af det, der er en œgtemands pligt, nemlig at sørge for sin hustrus kost og klœeder (se nœrmere i Ex 21,10). Til gengœld nœevnes ikke den sidste tredjedel, det œgteskabelige samvœr, hvis formål er, at kvinden også kan få sønner, der kan sørge for hende, hvis hun bliver enke. Som eneste formål med œgteskabet nœvner de deres egen œre, men dermed antydes også, at det ikke at have sønner eller mulighed for at få det er den virkelige katastrofe.

For en voksen kvinde er det en vanœre ikke at vœre gift og have børn. I Jes 54,1-10 skildres Jerusalems kommende herlighed, efter eksilet i Babylon, netop i billedet af den barnløse enke, hvis vancere fjernes, fordi Jahve igen tager hende til sig som sin hustru. I Jes 54,4 omtales enkestandens vancere med samme glose for vancre som i Jes 4,1: חרפה. I beretningen om Rakels œegteskab med Jakob, der lœenge var barnløst, fortcelles det, at da Rakel endelig føder en søn, udbryder hun: "Gud har fjernet min vanœre." Her, Gen 30,23, anvendes samme verbum, חרפה, og substantiv, i Jes 4, 1. Det er derfor sandsynligt, at enkerne, og Zion som enke, ikke kun skal forstås som kvinder uden mœend, men også som barnløse kvinder, der ikke har nogen som helst at støtte sig til. De er, som det 
hedder i v. 26, ribbet for alt. Situationen er derfor endnu alvorligere end den, der består i at miste smykker og andre luksusgenstande.

Den barnløse enkes vancere er et motiv, som er fœelles for Jes 4,1 og den deuterojesajanske opfattelse af de bortførtes situation i Babylon. I Jes 54 forkynder profeten en lykkelig fremtid i Jerusalem for de hjemvendte, for den barnløse skal blive mor til mange, når Jahve tager hende tilbage som sin hustru. I Jes 4,1 står det åbent, om kvinderne slipper af med vanceren. Men redaktionen har ved at placere Jes 4,2-6 i direkte forlœengelse vist, at de har samme positive forventning om en lykkelig fremtid for dem, der overlever. Dette kan vare med til at underbygge tesen om, at Protojesaja er blevet redigeret på baggrund af forkyndelsen i Deuterojesaja (se ncermere s. 32-35 samt 189193).

Tilbage til indholdsfortegnelsen

\section{Jes 4,2-6}

\section{Tekstkritik}

Der er ingen grund til at rette i teksten.

\section{Karakteristik}

Ligesom der efter anklagerne og domsoraklerne i kap. 1 følger et positivt orakel om Jerusalems fremtid i Jes 2,1-5, kommer der i Jes 4,2,-6 en forjœettelse om en lykkelig fremtid i Jerusalem (se ncermere i Kirsten Nielsen 1985, 272-282). Som centralt tema står renselsen og ophøjelsen af Zion. Det er endnu ikke indtruffet, men vil ske på den dag. Afsnittet står i klar modscetning til dommen i Jes 3,16-4,1 over Zion og Zions døtre. Teksten er sammensat og betragtes af mange forskere som en redaktionel tilføjelse fra eksiltiden eller fra eftereksilsk tid. Formålet har vœret at afrunde og tolke de forudgående kapitler, så det bliver tydeligt, at Jahves formål med straffen ikke er den totale tilintetgørelse, men redningen af en rest. Disse vers skal trøste og opmuntre, og de skal vise, at de politiske begivenheder er udtryk for Jahves vilje. Kapitlet knytter til ved temaer, som findes andre steder i Jes 1-12, ligesom billedsproget er velkendt. Dele af kapitlet kan derfor gå tilbage til den jesajanske forkyndelse, selv om sammenstillingen og placeringen af versene i den nuvœrende sammenhceng er tegn på den redaktionelle aktivitet, som prceger hele Protojesaja. 


\section{Struktur}

2-3 Forjœttelse om Jahves spire og Zions rest.

4-6 Orakel om udrensningen og Jahves beskyttelse af Zion.

\section{Fortolkning}

2-3

Forjœettelsen indledes med et fast udtryk: på den dag.

Faktaboks: Jahves dag

Udtrykket "på den dag", ביום ההוא, henviser til den dag, hvor Jahve vil gribe ind og vise sin magt. Det bruges adskillige gange i Jes 1-12: Jes 2,1 1.17; 3,18; 4,1; 4,2; 5,30; 7,18; 7,20; 7,21; 7,23; 10,20; 10,27; 11,$10 ; 11,11 ; 12,1.4$. Oprindelig har man forventet, at det ville blive en sejrsdag for Jahves eget folk. Denne positive forståelse ad dagen ligger fx bag Jes 4,2 og 12,1.4. Indirekte skinner den også igennem i Am 5, 18, hvor Amos advarer sine egne mod at tro, at Jahves dag bliver lys. Tvœrtimod skal det blive en mørkets dag. Den negative opfattelse af Jahves dag findes også i Jes 1-12, se fx Jes 2,1 1.17 og 3,18. I Ez 7,19 bliver dagen kaldt Jahves vredes dag, ligesom Jerusalems ødelaggelse i Klages 2,22 kaldes for Jahves vredes dag.

Dagen er i Jes 4,2 tœenkt som noget positivt. Det er den dag, hvor Jahve vil gribe ind og redde en del af sit folk. Jahves spire, צמח יהוה, er billedsprog og må forstås ud fra andre steder i Jes 1-12, hvor der anvendes plantemetaforik. Ligesom billedet af den barnløse enke, som håber på at få en mand, peger frem mod, at hun atter kan blive frugtbar, Jes 3,16-4,1, fokuserer plantebilledet i Jes 4,2 på den nye frugtbarhed. Der siges her ikke noget om, at der er gået noget negativt forud. Men andre steder i Jes 1-12 anvendes billedet af den nye spire netop til at vise, at til trods for at traet er blevet fœeldet, så vil det spire igen, Jes 6,13 og 10,33-11,1. Som forudscetning for den nye frugtbarhed må man derfor forestille sig en mangelsituation.

Jahves spire, צמח יהוה, kan tolkes generelt som udtryk for den kommende frugtbarhed. Men i lyset af andre steder i Jes 1-12 er det mere sandsynligt, at der tcenkes på en scrlig person, nemlig kongen (se ncermere i kommentaren til Jes 6,13; 9,5-6; 11,1-9 samt faktaboksen om Messiasforestillingerne s. 174-175). I den aramaiske oversœttelse, Targum, til Jes 4,2 gengives udtrykket med Jahves Messias, משיחא דיהוה, og i Jer 23,5; Jer 33,15; Zak 3,8 og Zak 6,12 bruges צמת om en kommende konge. Ganske vist er der i Jeremiasteksterne tale om Davids spire og ikke Jahves spire, men ud fra fx de gammeltestamentlige salmers kongeforståelse kan kongen med lige så god ret kaldes Jahves 
søn, SI 2,6-7 og 89,27-28 (se også 2 Sam 7,14). At forestillingerne om ny vakst er forbundet med kongeideologien, fremgår som ncevnt af andre steder hos profeterne, men terminologien ligger ikke fast. I Jes 1 1,1 bruges gloserne נצר om de nye skud af Isajs rod (se ncermere i kommentaren til Jes 11,1), og da tankegangen genoptages i Jes 11,10, er det med glosen I Jes 53,2 anvendes gloserne שיש og יונק. Disse forskellige vœkstbilleder er fœlles om at angive kongen som den livskraftige, der bryder igennem og dermed indvarsler en ny tid. Den store kongesalme, SI 72, viser desuden, at kongen ud over at vœre retfcerdig i sit styre af landet og sejrrig i sine krige også er garanten for landets frugtbarhed, SI 72,16.

\section{Faktaboks: Kongeideologi}

Kongen spiller en vigtig rolle ikke blot i den protojesajanske forkyndelse, men også i Davids Salmer. Forestillingerne om kongen, kongeideologien, indeholder en rœkke forventninger til kongen og dennes forhold til Jahve. I SI 2 er forholdet skildret som et far-søn forhold (se også SI 1 10,3), hvor Jahve har overdraget kongen magten over de fremmede folkeslag. Det ncere forhold kan også udtrykkes som i SI 1 10,4, at kongen er prcest for evigt. I SI 72, hvor kongens mange opgaver beskrives, er kongen et menneske, som Gud har sat til at herske og derigennem skabe gode forhold i riget i form af sejr over fjenderne, retfardige forhold for de svage i samfundet og frugtbarhed på marken. At Jahve har udvalgt Davidsslœgten som sin kongeslœgt fremgår af flere salmer, hvor pagten mellem Jahve og kongen understreges, SI 132 og 89. Jahve har dermed forpligtet sig til at bevare den davidiske slcegt på tronen i Jerusalem til evig tid. Det er disse forestillinger, der ligger bag forhåbningerne til den kommende konge i Jes 1-12. Netop derfor bliver Jesajas forhold til den aktuelle konge, kong Akaz, så anspaendt, da Akaz under den syrisk-efraimitiske krig viser sin manglende tillid til, at Jahve vil beskytte kongeslœegten (se nœrmere i kommentaren til Jes 7,1-17).

Når der i paralleludsagnet i Jes 4,2 tales om פרי הארץ kunne dette tolkes bogstaveligt om landets frugtbarhed (jf. Deut 1,25). Men det er også muligt at forstå udtrykket som endnu et billede på kongen selv. For en sådan forståelse taler de gloser, der yderligere anvendes i v. 2. Jahves spire skal blive til herlighed, צבי, (jf. brugen af glosen i Jes 13,19; 23,9; 24,16; 28,1.5) og cere, כבוד, (jf. brugen i Jes 3,8; 4,5 og 6,3, hvor œren er forbundet med Jahve selv, og brugen i Jes 8,7; 10,16, hvor det er forbundet med assyrerkongen, samt Jes 1 1,10, hvor det er Isajs rodskuds bolig, der er forbundet med œre). Om begge gloser gœlder således, at de som oftest bruges om levende vœsner og ikke om genstande. 


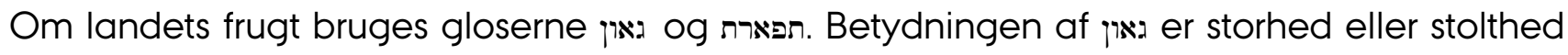
og bruges tydeligvis om levende vœsener, fx Jes 2,10.19.21; 13,11.19 og 14,1 1. Glosen תרפת anvendes om fremtrœdende personers pragt eller stolthed, Jes 3,18; 10,12; 13,19 og 28, 1.4.5. Det er derfor sandsynligt, at også landets frugt skal forstås som et billedligt udtryk for dets konge, som Israels overlevende skal betragte som deres stolthed og pryd.

I v. 3 skildres fremtiden for den rest, der er tilbage i Jerusalem. Fra at fokusere på den ypperste af indbyggerne i Jerusalem, kongen, går teksten videre til de øvrige af dem, der udgør resten (se ncermere om resttanken i kommentaren til Jes 7,3 og tolkningen af navnet Shearjashub). Denne gruppe karakteriseres ncermere som hellige og som dem, der er indskrevet til livet. Ved personers hellighed forstås deres nœre forbindelse med Gud. Jahve selv omtales hos Jesaja ofte som den hellige (se fx Jes 1,4 og helligsangen i Jes 6,3), og de hellige er her dem, der er rensede, v. 4, og derfor kan møde den hellige Gud, og som er under hans livgivende velsignelse. I SI 69,29 omtales en livets bog, hvor de retfcerdige er optegnet (se også Dan 12,1).

\section{4-6}

Disse vers beskriver først forudscetningen for, at der bliver en rest tilbage, nemlig en renselsesproces. Det er Zions døtre (jf. Jes 3,16), der skal have vasket urenheden af. Glosen betegner ekskrementer, men må her vœre billedligt anvendt om alt det, der adskiller dem fra Jahve.

Det blod, der skal fjernes, er et billede på den uret, herunder mord, der er blevet begået i byen (se Jes 1,15). Midlet til at gøre dem rene er dommens ånd, רוח משפט, og udrensningens ånd, רוח בער. Prœcis hvordan man skal forestille sig en sådan udrensning er vanskeligt at sige; men det er afgørende, at det sker ved ånden, og at det derfor er Jahve, som er den egentligt handlende. Det er ham, der trœffer den retfœrdige beslutning om Jerusalems fremtid (se også Jes 28,6). Og hans ånd er desuden karakteriseret ved, at den kan brœnde, בער, Jes 9,17; 10,17 og 30,27. Fœnomenet ild kan i Det Gamle Testamente anvendes som billede på Jahve selv, Deut 4,24. Denne betydning giver god baggrund for v. 5, hvor der tales om en flammende ild. Verbet anvendes desuden i betydningen afgnave, fx Jes 3,14 og 5,5 .

Efter udrensningen følger en scrlig beskyttelse af Zion og menigheden. Forestillingen om en sky om dagen og en ild om natten kendes fra ørkenvandringstraditionerne, hvor Jahves nœrvœr beskrives på tilsvarende måde, Ex 13,21-22. Med verbet skabe, ברא, der specifikt bruges om Jahve som skaber, fx Gen 1,1 og Jes 42,5, understreges den nye begyndelse. Som begrundelse hedder det, 
at der skal vare et dcekke over alt herligt. Det er glosen כבור, der bruges om det herlige. Denne glose bruges ofte i forbindelse med Jahves tilsynekomst, teofani, men må vel her vare brugt om Zion som det sted, hvor Jahves herlighed bor. Tanken om beskyttelse af Zion i fremtiden fortscettes i v. 6, men nu på en overraskende prosaisk måde. For at beskytte festforsamlingen mod dagens hede og mod de skybrud, som de kan blive udsat for, skal der vœre en hytte. Glosen for hytte, הכo, bruges i flere af salmerne som betegnelse for det sted, hvor Jahves tilhcengere kan søge tilflugt, SI 27,5; 31,21 (se også SI 18,12 og Jes 1,8) og er her udtryk for samme tanke. Men hvor bogstaveligt verset skal forstås er vanskeligt at afgøre.

Som helhed udtrykker Jes 4,2-6 håbet om en fremtid for udvalgte dele af folket og angiver derfor et gennemgående tema i Jes 1-12. Straffen er nødvendig, da folket og dets ledere har brudt deres forhold til Jahve. Men efter straffen, der fungerer som en renselsesproces, hvorved en rest udskilles, venter en ny fremtid skabt af Jahve selv.

Tilbage til indholdsfortegnelsen

Jes 5,1-7

Tekstkritik

Der er ingen grund til at rette i teksten.

\section{Karakteristik}

Vingårdslignelsen betragtes af nœsten alle forskere som œgte jesajansk (se ncermere i Kirsten Nielsen 1985, 117-169). Den går tilbage til profeten Jesajas tidlige virke, hvor Israel og Juda endnu ikke har oplevet de ødeløggelser, der fulgte med den syrisk-efraimitiske krig. Det er nœppe muligt at afgøre prœcis, ved hvilken lejlighed profeten har fremsat sin vingårdssang. Det kunne vœre ved en fest for høsten, hvor talen om vingården måske i første omgang får tilhørerne til at tro, at det er en høstsang. Eller det kunne vœre ved en lejlighed, hvor man snarere venter at høre erotiske viser og derfor hœfter sig ved, at profeten begynder med at prcesentere sine ord som en kœrlighedssang? Men det kan i øvrigt vœre når som helst, profeten havde mulighed for at fremsctte sine anklager for et lydhørt publikum.

Sammenligner vi de profetiske udsagn i Jesajabogen eller i en af de andre profetbøger med profetfortcellingerne i Det Deuteronomistiske Historievœrk, er der den store forskel, at vi som of- 
test mangler de fortcllinger, der kunne give en fortolkningsramme for det, profeten siger. I Jesajabogen er der enkelte steder overleveret fortcllinger, Jes 6-8; 20; 36-39, der kan hjœlpe til fortolkningen af udsagnene. Alle andre steder er det uhyre vanskeligt at rekonstruere en form for kontekst ud over den sammenhœeng, som redaktionen har placeret de enkelte udsagn i. At der har vœret et behov for at scette vigtige tekster ind i en fortcellesammenhceng (evt. en historisk sammenhceng) kan i $\varnothing v$ rigt ses af Salmernes Bog, hvor redaktionen i flere tilfœlde ved hjœlp af overskriften har sat en salme i forbindelse med begivenheder i Davids liv (se DKDSI., 38-39).

Afsnittet er klart afgrcenset i forhold til kap. 4 og de følgende veråb og omtales almindeligvis som vingårdslignelsen. At der er tale om billedsprog fremgår klart af v. 7, der giver en udlagning af vingårdsbilledet. At der er tale om en lignelse strider ikke imod den indledende angivelse af teksten som en sang. Det valgte billedsprog gør det nemlig ncerliggende for tilhørerne at tolke sangen som en sang om et forhold mellem en mand og hans hustru, hvor kvinden er skildret i billedet af en vingård, og manden i billedet af vingårdens ejer. Endnu et trœk ved teksten hører med til formbestemmelsen. I v. 3 henvender profeten sig til tilhørerne og beder dem tage stilling i den retssag, som sangen har udviklet sig til.

Teksten opererer således på flere niveauer: Det er en kcrlighedssang, som er formet i billedsprog, men med v. 3 bliver det klart, at det også er en retstale: Først skildres vingårdsmandens (œegtemandens) egne gode gerninger over for vingården (hustruen), så kommer anklagen (vilde druer / uœgte børn) og derpå straffen (ødelœggelse). Med v. 7 følger afsløringen af billedsprogets sande betydning: Israel er den utro hustru/den vingård, der opfører sig unaturligt, og som derfor fortjener straf af sin herre, Jahve selv. Dels ved hjœlp af det valgte billede dels ved hjœlp af retstaleformen kan profeten argumentere for, at Jahves kommende straf er nødvendig og retfœrdig, da den rammer det utro folk, der har opført sig aldeles naturstridigt ved at svigte sin egen Gud.

\section{Struktur}

1-2 En kcerlighedssang om en vingård, der bliver passet godt, men bœrer vilde druer.

3 Opfordring til tilhørerne om at falde dom i sagen om vingården.

$4 \quad$ Anklagerens uskyldserklcering.

5-6 Kendelse i form af domsorakel mod vingården.

$7 \quad$ Udløegning af billedsproget: Vingården er Israel og Juda. 


\section{Fortolkning}

$1-2$

Sangen begynder med et verbum i 1. person singularis. Det er profeten, der vil synge en sang om sin ידיד Gruges i Det Gamle Testamente ncesten udelukkende om personer, der omtales som elskede af Gud, Guds yndlinge, Deut 33,12; Jer 11,15; SI 60,7; 108,7 og 127,2. Parallelt hermed kaldes sangen for en שירת דודי Ordet רוד har udpraeget erotiske toner. Det bruges i Højsangen hele 34 gange om den elskede, fx Højs 1,13.14.16; 2,3.8.9.10, mens salmen om kongens bryllup i overskriften, SI 45,1, betegnes som en שיר ידידת. Tilhørerne til sangen vil derfor hurtigt blive sporet ind på, at det er en sang om et erotisk forhold, selv om glosen ידיר kunne pege i en anden retning.

Hvem forholdet drejer sig om, er ikke ganske klart. For når profeten omtaler sin ven med en erotisk konnoteret glose, vil tilhørerne forvente, at det er forholdet mellem de to, profeten vil synge om ved at synge den elskedes sang. Derfor opstår der et sammenstød mellem forventningerne og det, der siges yderligere om sangen, nemlig at det er en sang om den elskede vens vingård.

Tilhørerne må dog forventes at vœre i besiddelse af tilstrckkeligt kendskab til gœngs billedsprog til at ane, at vingården ikke skal opfattes bogstaveligt. Glosen for vingård, כרם, anvendes nemlig i Højsangen som billede på kvinden, Højs 1,6; 2,15; 8,12. Den følgende beskrivelse af vennens behandling af vingården viser, at han gør alt, hvad man kan forvente af en mand, der anlaegger en vingård. Stedet, hvor vingården anlœgges, beskrives som en frugtbar skråning. Dermed skulle en vigtig del af vœkstbetingelserne vœre sikret. Lœst billedligt betyder det, at kvinden får gode forhold at leve under i œgteskabet.

I v. 2 uddybes beskrivelsen af vingårdsejerens arbejde med vingården. Også her skildres ejeren som en omhyggelig mand, der sørger for alt det nødvendige: Han graver jorden og fjerner stenene, før han planter vinstokke af god kvalitet. Ordet for vinstok, שריק, anvendes også i Jer 2,21, hvor vinstokken yderligere betegnes som en œgte stikling, זרע אמת. Ud over at vaelge en god beliggenhed og en god vindruesort, sørger ejeren for at beskytte sin vingård. Fra vagttårnet kan man holde øje med, at vilde dyr eller andre ubudne gœester ikke bryder ind i vingården og ødelœgger planterne. Desuden bygger han en perse, så alt er klart til at høste druerne og presse saften af dem. Forudscetningerne for hans positive forventninger til vingården er derfor i orden. Skuffelsen over de dårlige vindruer er fuldt ud forståelig. Vinstokkene har ikke båret de druer, man med rette kunne forvente. Det er mod naturens orden, at vinstokkene bœrer vilddruer. 
Tilsyneladende er dette en dagligdags skildring af hverdagen for en vingårdsejer, men lœest i lyset af den indledende bestemmelse af sangens erotiske karakter samt datidens brug af vingården som billede på en kvinde, må man spørge, om ikke også denne del af sangen skal forstås billedligt. Nogle forskere peger på, at det ikke svarer til forventningerne om en kcrlighedssang, at den handler om mandens slid og slceb. I stedet skulle en kœrlighedssang vare en lovprisning til vingården for dens mange kvaliteter, svarende til at Højsangen netop jubler over kvindens yndigheder, $f x$ Højs 7,7-10. Og det er ganske korrekt. Skildringen er anderledes, men det skyldes, at endnu en Gattung allerede her bringes ind i teksten, nemlig retstalen.

I en retssag, hvor en vasal er anklaget for at have brudt pagten med sin herre (se ovenfor s. 16-17), er det almindeligt, at denne storherre begynder med at fortcelle om sine egne velgerninger mod vasallen. En sådan selvlovprisning fungerer som en uskyldserklcering, der giver ekstra vœgt til de anklager, som storherren vil fremføre for at vise, at vasallen har brudt pagten. Nu handler Jes 5 ganske vist ikke om en politisk storherre, men om en vingårdsejer, der anklager sin vingård, og som i øvrigt er billede på en œgtemand. Alligevel ligner strukturen også den struktur, man måtte forvente ved en skilsmissesag, hvor œgtemanden begynder med at erklœre, at han selv er aldeles uskyldig $\mathrm{i}$ det, der er sket. Han har gjort, hvad han kunne. Alene hustruen er ansvarlig.

Også indholdet af verset kan tolkes billedligt. Det var ikke usœdvanligt i Den Nœre Orient at bruge billedet af kvinden som en mark, der bearbejdes af œegtemanden og sås til af ham, eller som her beplantes af ham. Ikke alt i en lignelse skal kunne oversœttes, men hovedpointen er klar: Ægtemanden yder, hvad han skal også på det seksuelle område. Man må derfor forvente, at hun føder hans børn. Lœest billedligt er vilddruerne netop ikke hans børn.

\section{3}

Med v. 3 skifter teksten fra en beskrivelse i tredje person af vingårdsejeren til 1. person. Nu kommer vingårdsejeren selv til orde med en opfordring til tilhørerne til at fœelde dom i sagen (verbet שפט, bruges her i juridisk betydning) mellem ham og vingården. Situationen bliver dermed mere intens. Tilhørerne er mandene i Jerusalem og Juda, dvs. profetens ncermeste landsmœend. At et forhold mellem œgtefœller kan ende som en skilsmissesag, har nœppe overrasket dem, når det har vist sig, at hustruen har fået børn med andre end œgtemanden (jf. en tilsvarende retssag i Hos 2,4-17). Da tilhørerne opfordres til at påtage sig rollen som dommere i sagen, vil de formentlig også betragte det 
som temmelig oplagt, at kvinden skal dømmes hårdt. Efter gammeltestamentlig lov straffes œgteskabsbrud med døden (se Lev 20,10; Deut 22,22 samt forbuddet i Ex 20,14).

\section{4}

For at gøre sin egen situation helt klar spørger vingårdsejeren tilhørerne, om han mon skulle have forsømt noget i forhold til sin vingård? Og om de har nogen forklaring på, at vingården gav vilddruer i stedet for de gode druer, han måtte forvente? Begge spørgsmål er retoriske og må besvares med et nej. Der kan ikke rettes nogen form for anklage mod ejeren af vingården. Og med konstateringen af hans uskyld, bliver hendes skyld indiskutabel.

\section{$5-6$}

Netop som man ville vente, at tilhørerne skulle komme til orde og optrade som dommere i sagen, fœelder vingårdsejeren selv dommen over sin vingård. Nu er der nœppe grund til at forvente, at tilhørernes dom ville vare faldet anderledes ud. Deres manglende udsagn betyder ikke, at de er uenige i dommen; den har de formentlig allerede selv fœldet i deres hjerte. Ejeren kalder stadig vingården for min vingård, כרמי, men det ncre forhold mellem de to er netop ikke en formildende omstcendighed. En ejer har ret til at forvente lydighed fra den, han ejer (jf. Jes 1,3, hvor dyrenes kendskab til ejeren stilles op som modscetning til det ulydige Israel). Med til en vingårdsejers og en œegtemands forpligtelser hører, at han skal beskytte sin ejendom mod angreb udefra. Denne forpligtelse er ikke lœngere aktuel, hvorfor ejeren netop vil fjerne al beskyttelse, så vingården løgges blot, og andre kan komme og trampe på den og gnave den ned.

Verbet har to betydninger, brœende eller afgnave. Glosen bruges flere gange i Jes 1-12 (se fx Jes 1,31; 9,17 og 10,17, hvor det er i betydningen brcende), men her er det betydningen at afgnave, der er den mest ncrliggende (jf. Jes 3,14). På billedplanet er der vel iscr tcenkt på vilde dyr og fremmede hcre. Vingården skal blive trampet ned, hvilket peger i samme retning, da glosen מרמס netop bruges enten om dyr, SI 80,14, eller om fjendtlige haere, der kommer trampende, fx Jes 7,25; 10,6; 28,18. Ud over ikke lœengere at beskytte vingården vil ejeren også lade den forfalde. På hebraisk står der "jeg vil gøre den til בתה". Ordets betydning er usikkert, men det må betyde noget i retning af $\varnothing$ de land. Ejeren vil heller ikke foretage den nødvendige beskcring af vinstokkene, ligesom jorden omkring dem heller ikke vil blive passet laengere. Resultatet bliver, at den gror til med torn og tidsel. Dette udtryk, שמיר ושית, bruges i Jesajabogen til at markere det vardiløse, Jes 7,23.24.25; 9,17; 
10,17; 27,4 (se også Gen 3,18). Her er det ncerliggende at forstå disse vcekster i forlcengelse af beskrivelsen af, hvordan vingården skal trampes ned. I så fald er tanken den, at når den virkelige ejer opgiver sin vingård, så kommer der vardiløse nye herskere og udbytter den, så der ikke bliver noget tilbage af den. Lœst som billede på en utro hustru betyder det, at hun ikke lœengere bliver beskyttet mod andre mcend af sin cegtemand.

Det sidste led i straffen består i, at ejeren vil forbyde skyerne at regne og dermed hindre vingården i at overleve. Uden regn kan vinstokkene ikke gro og baere frugt. At ejeren skulle have magt til at bestemme over skyerne virker urimeligt, hvis man forestiller sig, at ejeren er et almindeligt menneske. Mange forskere vil derfor mene, at selv om tilhørerne indtil nu ikke har forstået, at det er Gud selv, der er vingårdsejeren, så vil omtalen af denne straf gøre det klart for dem. Kun Gud kan styre regnen. Men igen er der i det gammeltestamentlige billedsprog mulighed for at tolke udtrykket inden for rammen af œegteskabsbilledet. I Hos 2,20-25 skildres genoprettelsen af pagtsforholdet mellem Jahve og hans folk i billedet af en forlovelse. Og i forlcengelse af selve forlovelsen beskrives det, hvordan Jahve vil svare himlen, som så skal svare jorden, der skal svare kornet, vinen og olien. Tanken er, at den regn, som himlen giver jorden, og som er forudscetningen for, at frugtbarheden kommer, og at korn, vin og oliven kan gro, er som den mandlige sced, der befrugter den kvindelige jordbund. Hvad œgtemanden vil gøre er at afbryde det œgteskabelige samliv og dermed hindre hustruen i at blive gravid.

Tilhørerne kan derfor indtil nu sagtens have regnet med, at lignelsen handlede om en utro hustru, og hvordan den svegne œgtemand nu vil skilles fra hende. Og ingen af tilhørerne vil finde det urimeligt på baggrund af mandens anklager mod den utro hustru.

\section{7}

Udlagningen af lignelsen kommer derfor som et slag i ansigtet. Det handler ikke om en tilfœldig kvinde, men om Israels hus og Judas mœnd, dvs. Jahves eget folk, Nordriget såvel som Sydriget. Profetens ven er Gud selv. Fortcelleteknikken er den samme som i 2 Sam 12,1-15, hvor profeten Natan fortceller David om den fattige mands eneste lam. En rig mand får gœester, men da han ikke ncenner at bruge et af sine egne dyr, tager han den fattige mands eneste lam og serverer det for sine gœster. David reagerer voldsomt over en sådan behandling af den fattige og erklarer, at den rige skal straffes med døden. Natans svar på Davids domfœldelse af manden lyder: "Du er manden!" David har dømt sig selv for den forbrydelse, han begik, da han tog Urias' hustru Batseba til sig og endda 
sørgede for, at Urias selv blev drcebt. Uden at vide det har David udtalt en selvfordømmelse, som han må bøje sig for.

Tilhørerne til Jesajas lignelse har ikke direkte udtalt en tilsvarende dom, men da de blev opfordret til at fœlde dom, v. 3, har de uden tvivl i tankerne fœldet dødsdom over den utro kvinde. Nu opdager de, at den rammer dem selv. Vingårdens ejer er Jahve, der her omtales som Harskarers Jahve, dvs. den magtfulde Gud. Vingården er ikke billede på en kvinde, men på et helt folk. At bruge vinstokke som billede på Israel kendes også fra SI 80,9-14 samt fra Jer 2,21, hvor kapitlet indledes med billedet af folket som Jahves brud. Vinstokkene i vingården beskrives i v. 7 som Jahves yndlingsplanter, שעשועיו. Ligesom i v. 2 er det gode vinstokke, som man med rette kunne vente god frugt fra. Glosen שעשועם bruges i Jer 31,20 om Efraim (Nordriget) som Jahves yndlingsbarn, en søn, som Jahve er tcet knyttet til.

Hvad Jahve forventer af sit yndlingsfolk er ret og retfcrdighed. De to gloser משרפה og står parallelt. משפט omfatter såvel overholdelse af konkrete bud, herunder også skik og brug, som adgang til retfœerdig sagsbehandling i tilfœelde af retssager. צדקה betegner, at noget er, som det skal vare, og dermed den rette måde at omgås hinanden på i samfundet, så alle trives. Det er det gode og velordnede samfund, der retter sig efter Jahves vilje, der er idealet (se Jes 1,21-26). Baggrunden for dette er den basale forestilling om, at Gud har skabt verden som en ordnet verden. Det er gang på gang denne orden, mennesket har sat sig op imod ifølge Jesajabogen.

Samme kontrast mellem forventninger og virkelighed, som er beskrevet i v. 4, gør sig gœldende i v. 7. For at slå sin pointe fast og gøre det lettere at huske den bruger profeten ordspillet som stilistisk virkemiddel. Hvad virkeligheden bød på lyder nœsten som idealet; men der er en verden til forskel. I stedet for משפח kom der משפט, et ord, der angiver brud på loven, og i stedet for צדקה kom der צעקה, der betegner ofrenes råb om hjœlp. Det er vanskeligt at gengive rim (ordspil) på et andet sprog. I 1931 oversœttelsen har man forsøgt sig med en forholdsvis fri overscettelse. "Han vented paa Retfœerd - se, der kom Letfœrd, han vented på Lov - se, Skrig over Rov!" for at bevare rimene. DO 1992 nøjes med at gengive ordenes betydning.

Med v. 7 afsløres det, at tilhørerne har tolket billedsproget om vingården forkert. De har hørt, hvad de gerne ville høre, de har fœldet den dom, som de troede gjaldt en anden end dem selv, men nu står dommen ved magt. Det er dem, der har båret vilddruer. Hvad vilddruerne er billede på fremgår af ordene צעקה og, retsløshed og nødskrig. Det er den frugt, vinstokkene bar. Og hvor de troede, at vingårdsejeren var en landsmand, opdager de nu, at ejeren er Jahve selv. 
Faktaboks: Vingårdsbilledet i Jes 27,2-6

Vingårdslignelsens billedsprog har vcret velegnet til genbrug og reinterpretation. Et oplagt eksempel er den anden vingårdssang, Jes 27,2-6. De to vingårdssange står i et antitetisk forhold til hinanden. Jes 5,1-7 handler om en fiasko, mens Jes 27,2-6 handler om en succes. Ved at genbruge billedet om Israel som vingården kan forfatteren til Jes 27,2-6 ikke udnytte den overraskelseseffekt, som var strategien i Jes 5,1-7, hvor tolkningen af billedet først kommer i v. 7. Det røbes derfor straks fra v. 3 , at det er Jahves vingård. Overraskelsen må derfor ligge et andet sted, hvis oraklet ikke blot skal vœre en gentagelse af den gamle vingårdslignelse. Det overraskende består derfor i, at alt det negative nu er fjernet. I stedet for rettergangsmotivet og dommen handler det nu om omsorg og lovsang. Formålet er at trøste og opmuntre lœeseren. Og her kan selve vingårdsbilledet bruges som argumentation for, at Jahve er en omsorgsfuld ejer, som passer og bevogter sine vinstokke. Det ved lœeseren allerede fra den gamle version. Jes 27,2-6 stammer fra eftereksilsk tid, hvor den nye situation har krcevet en ny tekst, men med basis i den gamle tekst. Forfatteren har skabt en kontrastfortcelling, hvor en rakke motiver vendes 180 grader, og hvor vingårdssangen får en ny afslutning, der skildrer Israels blomstrende fremtid. For efter den retfœrdige ødelœggelse af vingården ønskede Jahve, at den skulle spire igen. Vingårdsbilledet er også anvendt i Jer 2,21; Jer 5,10; Jer 8, 13, ligesom det bruges flere gange i Ny Testamente, se fx Joh 15,1-8. Generelt må det siges, at en sådan genbrug og reinterpretation er karakteristisk for den profetiske forkyndelse, hvor centrale udtryk, ofte i billedsprog, kan genbruges i nye situationer, reinterpreteres og undertiden også give anledning til ny tekstproduktion. Formålet med genbrug er da bl.a. at bevare den autoritet, som er knyttet til den œeldre tekst.

Tilbage til indholdsfortegnelsen

\section{Jes 5,8-24}

\section{Tekstkritik}

$13 a$

MT: sultens mœend. Vokaliseringen œndres, så der står: sultens døde. Dette krœver blot, at shewa œndres til sere. Rettelsen, BHSa, støttes af flere af de gamle overscttelser. 


\section{$17 d$}

MT: fremmede. Rettelsesforslag BHSd: geder. For rettelsen taler, at geder passer bedre som parallel til får, samt at LXX støtter denne forståelse. Skriveren har i så fald forvekslet de to bogstaver d og r, som ligner hinanden meget.

\section{Karakteristik}

Kapitlet fortscetter med seks veråb. Veråb forbindes med død og dødsklage. De skal i denne sammenhceng markere, at de, der rammes af veråbet, allerede er dødsens på grund af deres handlinger. Veråbene er rettet mod overklassen, som udbytter de svage, og mod dem, som glemmer Jahve til fordel for deres egne nydelser. Videre gœelder veråbene dem, som lyver og bedrager uden at regne med, at Jahve vil gribe ind, og dem, som ikke kan skelne mellem godt og ondt, men regner sig selv for vise. Endelig rammes de, som er fordrukne og tager mod bestikkelse, så skyldige bliver frikendt, og uskyldige ikke får deres ret. I flere af veråbene udtales desuden trusler om, hvordan Jahve vil straffe dem. Genremcessigt sker der hermed et skift fra sangen/lignelsen om vingården til veråb. Ligesom veråbene i Jes 1 har fået en scrlig funktion, nemlig at fungere som dom over folket, fordi de som ulydige børn har brudt med deres far, således har veråbene i Jes 5,8-24 også fået deres scerlige funktion. Ved at placere dem i direkte forlœngelse af vingårdslignelsen vil redaktorerne vise, hvad det vil sige at bare dårlige druer, nemlig at lade hånt om Jahve og i stedet tilfredsstille ens egne behov. Eksemplerne på frafaldet skal desuden fungere som bevis for, at den dom, der udtales $\mathrm{i}$ vingårdslignelsen, er retfœrdig. Ikke blot ventede Jahve retfœrdighed af sit folk, Jes 5,7, Jahve udøver også selv retfœrdighed, Jes 5,8-24. Det er derfor også konsekvent, at nogle af veråbene efterfølges af beskrivelser af, hvordan straffen skal blive. Når et veråb derimod står uden en sådan uddybning, overlades det til lœeseren selv at forestille sig, hvordan det skal ende.

\section{Struktur}

8-10 Veråb over storgodsejerne, der til straf skal miste alt det, de har samlet sig.

11-14 Veråb over dovne og drikfceldige, der til straf skal sulte og tørste og eksileres til dødsriget.

15-17 Sentens om ydmygelse af mennesket og ophøjelse af Jahve.

18-19 Veråb over dem, der spotter Jahves planer.

20 Veråb over dem, der bytter om på godt og ondt.

21 Veråb over de hovmodige, som tror, de er vise. 
22-24 Veråb over de drikfœldige, som tager mod bestikkelse, men som til straf for deres foragt for Jahves lov skal gå til grunde.

\section{Fortolkning}

8-10

Det første veråb er vendt mod de storgodsejere, som er i fœrd med at overtage al jord i landet og dermed fratager de dårligere stillede deres levebrød. I Det Gamle Testamente er kong Akab et velkendt eksempel på en stormand, der inddrager en andens jord med ufine midler, 1 Kong 21.

Ganske vist tilbyder han i første omgang Nabot at bytte sig til vingården eller betale for den; men da Nabot afviser, lader Akab sig overtale af sin kone, Jezabel, til at bringe Nabot for retten under påskud af, at han skulle have forbandet Gud og kongen. Da Nabot er straffet med døden, kan kong Akab overtage vingården. At der også i Jes 5,8 er tale om magtmisbrug understøttes desuden af et tilsvarende veråb i Mika 2,2, hvor det siges direkte, at stormœndene røver markerne og husene og undertrykker ejerne.

Når storgodsejerne anklages for misbrug af deres magt, hcenger det bl.a. sammen med synet på landet. Landet er Jahves og skal derfor fordeles og forblive fordelt, sådan som Jahve har ønsket det (jf. Num 26,52-56; 27,1-11). Den orden, Jahve dermed har skabt, må mennesker ikke œndre på. Nabot afviste da også kong Akab ved at henvise til, at det var hans fœdres ejendom. Jorden skal blive i slœgten.

At stormcendene skal straffes kommer som et påbud fra Jahve selv, her omtalt som den magtfulde Hœerskarers Jahve, יהוה צבאות. Straffen over storgodsejerne svarer til deres forseelse. De, der netop samler på store og fine huse og marker, skal opleve misvakst, så husene bliver tomme, fordi beboerne er døde. Misvaksten er beskrevet sådan, at indsatsen er betydeligt mindre end udbyttet. En anden mulighed er, at det er krigens ødelœggelser, der tœnkes på.

Det første eksempel gaelder udbyttet fra en vingård på צמדי־רם 10 צממר Glosengiver et spand trœkdyr (fx to okser), og angiver sammen med ordet for vingård, כרם, det stykke jord, som et spand okser kan pløje på én dag. Af så stor en vinmark bliver udbyttet kun på én bat, hvilket svarer til ca. 40 liter druer. Den mœngde såsced, man strør ud på marken, er ligeledes større end mœngden af det korn, man høster. Af én homer sced kommer én efa korn. Ordet homer, רמת, betegner den mangde et œsel, חמור, kan bcere, ca. 400 liter. En efa er ca. 40 liter (se ncermere i GBL: "Mål og vœgt"). Udbyttet er i dette tilfœelde kun 1/10 af, hvad der sås. En sådan misvœkst svarer til de for- 
bandelser, der i 5 Mosebog udtales over dem, der ikke adlyder Jahve, Deut 28,38. Pagtsbrud medfører Jahves forbandelse.

\section{$11-14$}

I det følgende veråb drejer det sig om personer, der fester døgnet rundt og glemmer Jahve. I stedet for at begynde dagen med at gå ud til arbejdet, går de i gang med at drikke øl og vin. Ud over at vœre drikfœeldige er de også dovne. Roden שכר betegner som substantiv øl, mens det som verbum bruges om at beruse sig (se fx om Noas beruselse i Gen 9,21 eller Jes 29,9 om Jahves straf). Vin er i Det Gamle Testamente generelt opfattet positivt. Vinen giver mennesket glœde, SI 104,15. I beretningen om spejderne, der før indvandringen i Det Forjœttede Land udforskede området, fortclles det, at de kom tilbage med en kœempe drueklase som tegn på landets enorme frugtbarhed, Num 13,23, og i Dom 9,13 hedder det, at vinen glœder både guder og mennesker. Men når vinen får som konsekvens, at man mister evnen til at vurdere, hvad der er vigtigt i tilvarelsen, nemlig Jahves handlinger, så er der tale om et misbrug, som bliver fordømt. I Ordsprogenes Bog hedder det kort og godt: "Vinen er en spotter, øl giver larm, ingen, der dingler af det, har visdom.", Ordsp 20,1. Også i Jes 28, 18 anvendes motivet beruselse.

Den udførlige skildring af festerne, hvor der spilles på strengeinstrumenter, citer og harpe, på slaginstrumenter, pauke, og på blceseinstrumenter, fløjte, viser, at der er tale om fester i velhavende kredse. At de ikke har øje for Jahves gerninger betyder, at de ikke forstår, hvad deres Gud har gjort for dem, de mangler den helt elementcre indsigt, der består i at anerkende Jahve og hans planer med folket (se også Jes 5,19). Udtrykket, Jahves hœenders vœrk, betegner hans skabervœrker.

Med v. 13 følger konsekvensen, indledt med לכן: derfor. Det er den manglende indsigt, som også blev understreget i Jes 1,3 (begge steder bruges roden ידע), der fører til straf. Her i v. 13 består straffen i eksilering. Verbet גלה bruges om deportation, fx i Jes 49,21 om dem, der blev ført til Babylon (substantivet גולה er den hebraiske betegnelse for landflygtighed, Ez 12,11). Her siges blot ganske kort, at de skal deporteres. Lœst i forlœengelse af det første veråb, hvor stormœndene forsøger at få hele landet som ejendom, indebcrer deportation netop tab af landet. Folket kaldes stadig mit folk, עמי, hvorved det antydes, at de netop burde have kendt Jahve og holdt sig til ham.

Hvem straffen rammer prœciseres herefter. Først nœvnes de fornemme, כבדו, og ganske kort nœvnes deres skœbne: De er sultens døde (jf. tekstrettelsen). Parallelt hermed kaldes folkets mœeng- 
de for tørstens udtørrede. To så elementœre behov som mad og drikke opfyldes ikke løengere. Sult og tørst står i kontrast til de fester, de hidtil har moret sig med.

Mens v. 13 taler ganske kort om eksilering, og man forventer deportation til et fremmed land, taler v. 14 langt mere radikalt om dødsriget som det sted, hvor de skal havne. Dødsriget, Sheol, er her beskrevet som et levende vœsen, et uhyre, som åbner gabet og sluger dem alle sammen. Billedsproget afspejler mytologiske forestillinger, der minder om skildringen af det store uhyre i SI 74, 13-14, hvor Jahve besejrer drageuhyret Livjatan. Dødsriget er i Det Gamle Testamente det sted, hvorfra ingen vender tilbage (jf. Job 7,9-10). Igen understreges det, at det er med god grund, de ender i dødsriget. Med gloserne שאון beskrives de som larmende og overmodige. Den lydlige lighed mellem de to hebraiske gloser forstcrker effekten, ligesom de mange lange a'er understreger sammenhœengen og måske også angiver en dyster tone. Ikke desto mindre er festdeltagerne lystige (jf. Jer 51,39, hvor verbet עלז bruges om at blive lystige, fordi man er beruset). De forstår ikke deres egen situation.

\section{$15-17$}

Rckken af veråb brydes herefter af en sentens, der er en nœesten ordret gentagelse af dele af Jes 2,9.11 om ydmygelsen af mennesket og de stoltes blik (se narmere i kommentaren til kap. 2 om temaet: Hovmod står for fald). Hermed understreges det hovmodsaspekt, som også indgik i veråbet over festdeltagerne. Også tanken fra Jes 2 om Jahves ophøjelse gentages. Men her i kap. 5 med en klar understregning af den domssituation, sentensen skal forstås ud fra (jf. vingårdslignelsen i Jes 5, 17 som et eksempel på Jahves retfœerdige dom over folket). Hœrskarers Jahve skal ikke blot vœre ophøjet som i Jes 2,1 1.17, men det skal ske ved, at Jahve fcelder retfœrdig dom, במשפט. Parallelt med בצדקה står, med retfcerdighed. I Jes 5,7 var det netop ret og retfcerdighed (se nœrmere om disse begreber s. 87), som Jahve forventede af sit folk, men ikke opnåede. Her i Jes 5,16 står Jahve selv inde for begge dele.

Jahve beskrives derudover som Hœrskarers Jahve og som den hellige Gud, der bliver helliget gennem sin retfœerdighed. Jahve er således ikke blot den stcrke, som har magten til at gennemføre sin dom, men p.g.a. sin hellighed kan Jahve ikke affinde sig med synden og må derfor gribe ind.

Selv om v. 15-16 genremœssigt bryder sammenhœngen, har redaktorerne haft en klar hensigt med netop at pege på Jahves retfœerdige handlen. Også disse vers er med til at understrege, at det ikke er uden grund, at Jahve har besluttet at straffe sit folk. 
Med v. 17 følger et udsagn, som nok ville give bedre mening i forlcengelse af det første veråb, hvor landet skal ligge øde hen. Nu er det dyrene, får og geder (jf. tekstrettelsen), der overtager, hvad der tidligere tilhørte stormœndene, som her er beskrevet som de fede. Motivet med de ødelagte byer, der skal blive til grcesgange findes også i Jes 17,2; 27,10 og 32,14. Ganske kort er dette tema desuden markeret i Jes 5,5, hvor hegnet fjernes, så vingården kan blive trampet ned.

\section{8-19}

Det tredje veråb henvender sig til dem, der håner Jahve og ikke tror på, at han kan gennemføre sine planer (jf. Jes 5,12). De beskrives som personer, der holder godt fast i deres skyld og synd. Billedet er ikke helt gennemskueligt. Hvis man tager udgangspunkt i glosen העגלה, så handler billedet om en vogn. Vogne blev dengang normalt trukket af et eller flere trcekdyr. Glosen עבות angiver så de reb, som forbinder trœkdyrene med vognen. I lighed med den danske overscttelse af stedet, kan man forstå det sådan, at de holder fast i deres synd på samme måde, som man bruger reb til at slabe en vogn. Teksten er meget knap på hebraisk og kan også overscttes: "og som vognreb [er] deres synd". I så fald ligger vaegten på, at synden i sig selv binder dem. Hvis det er nogenlunde det samme, der udtrykkes i første del af verset, så er der også her tale om, at de holder fast i deres skyld med reb. At rebene kaldes løgnereb gør det naturligvis ikke bedre. Uanset hvor pracist vi kan bestemme billedbrugen, er det afgørende i billedet, at de har bundet sig til det, som de burde frigøre sig fra.

I god forlœngelse heraf fortscetter v. 19 med at anklage dem for, at hvad de netop burde have holdt fast ved, det tager de afstand fra. De håner Jahve, når de opfordrer ham til at skynde sig lidt med at virkeliggøre sine planer, så de kan se, hvad han dur til. Ved at tale om Jahves handlinger og plan og om deres egne muligheder for at se og forstå dem parodierer de den traditionelle måde at tale på. Jahves handlinger er netop synlige og skulle derfor skabe tillid til Jahve (jf. anklagen for ikke at se handlingerne i v. 12). Og de skulle netop også føre til, at folket fik kendskab til Jahve (jf. brugen af roden ידע såvel her som i v. 13 og i Jes 1,3). Umiddelbart kan det lyde, som om de ønsker at indse og forstå, men de har totalt misforstået forholdet mellem dem og Jahve, når de tror, at de kan bestemme, hvornår Israels Hellige sœetter sine planer i vœrk. Veråbet får desuden en sœrlig funktion ved at vœre placeret kort før Jesajas Denkschrift (se nœrmere s. 99-101). For det er i Denkschrift, at Jahve for alvor viser sine planer om at redde folket fra fjenderne, blot de holder fast ved ham, Jes 7,4-9, men kong Akaz afviser at stole på Jahve. Veråbet er derfor med til at understrege det tragiske i, at de lader, som om de lœnges efter at se Jahve gribe ind. 
I modscetning til de to forudgående veråb indeholder dette ikke en beskrivelse af konsekvenserne af deres handlinger. Men enhver kan selv slutte sig til, at det må ende galt.

\section{0}

Det følgende veråb henvender sig til dem, der bytter om på de helt basale vardier. Hermed tiltager de sig en ret, som ikke tilkommer dem. Det er Jahve, der har bestemt, hvad der er godt, og hvad der er ondt. Det er udtryk for hovmod selv at ville bestemme (jf. at trœet til kundskab om godt og ondt netop ikke var bestemt for mennesket, Gen 2,17). Lyset er Guds første skabervark og forudscetningen for, at mennesker kan orientere sig, Gen 1,3. Byttes der om på lys og mørke, mister man muligheden for at finde vej. Bittert og sødt er også opfattet som modscetninger. Bittert vand er udrikkeligt, men forvandles det til sødt vand, så kan det igen drikkes (jf. beretningen om Moses, der gør bittert vand sødt/frisk i Ex 15,23-25). Det er altså helt basale forhold, de forsøger at cendre på. Heller ikke her anføres konsekvenserne; det overlades til løseren selv at drage sine slutninger.

\section{1}

Veråbet er ganske kort og angår dem, der mener at vœre vise, men tydeligvis kun er det i egen mening. Det er igen hovmodsmotivet. Gloserne חכמים, de vise, og de forstandige, er scerdeles positivt ladede. Josef roses netop af Farao for sin forstandighed og visdom, Gen 41,39, og i skildringen af den kommende konge af Davids slœegt, Messias, understreges det, at han skal vœre udstyret med visdoms og indsigts ånd, רוח חכמה ובינה, Jes 11,2. Men her er det netop Herren, der udstyrer ham med disse egenskaber, og ikke noget han selv mener at besidde. Mennesker, der forfalder til en sådan selvovervurdering, rammes derfor også af profetens veråb. Og de må selv tcenke sig til, hvordan Jahve vil reagere.

\section{2-24}

Med det sjette og sidste veråb genoptages temaet fra det andet veråb: drukkenskab. Forventningerne til helte gœelder normalt ikke deres evne til af drikke vin eller tilsmage $\varnothing$ med den rette mœengde krydderier og honning, men derimod deres udholdenhed og dygtighed i forskellige krisesituationer. Parallelt med de fordrukne ncevnes de dommere, der tager mod bestikkelse og derfor dømmer uretfcrdigt. De frikender dem, der har råd til at betale for det, mens de, der ikke har råd til det, bliver dømt skyldige, selv om de er uskyldige. På hebraisk hedder det, at de retfœrdiggør (verbet 
צדק i hifil participium) den, som er skyldig, רשע. Omvendt fjerner de (verbet סרע i hifil) de retfcrdiges retfcrdighed fra dem. Retfœerdighed får man tilkendt i retten, når man frikendes. I Jes 1,23 anklages Jerusalems stormœnd netop for at lade sig bestikke, så de ikke skaffer den faderløse og enken deres ret. Både hang til berusende drikke og begcer efter penge fører ifølge Jes 5,22-23 til, at man ser stort på, hvad der er ret og rigtigt.

Efter første del af veråbet følger i v. 24 en beskrivelse af straffen, indledt med et begrundende לכן, derfor. Straffen beskrives ved hjcelp af billeder fra naturen. Disse helte er som det tørre strå og høet, der hurtigt brœnder op. Ilden bruges i Jes 1-12 flere gange om den totale tilintetgørelse, Jes 1,31; 9,17 og 10,17. Videre sammenlignes de med en plante eller et trœ, hvis rod rådner. Der er ikke, som det er tilfœeldet i Jes 11,1, hvor trœet kun er fœldet, grokraft tilbage i roden. Og når roden går til, visner også blomsten og bliver til støv. Ethvert håb om en fremtid er dermed fjernet.

Som yderligere begrundelse gøres det klart, at de har forbrudt sig mod תורת יהוה צבאות. Det er igen Jahve som hœrskarers Jahve, den magtfulde, der henvises til. De anklages for at forkaste Jahves תורה og lade hånt om hans ord (jf. at תורה ikke kun betyder lov = Moseloven, men mere generelt betegner belcring). Verbet מאם, forkaste, anvendes i forbindelse med anklage for at bryde pagten i Lev 26,15 (se også Lev 26,43). Verbet נאי, lade hånt om, bruges i Jes 1,4 i veråbet over de ulydige børn, der lader hånt om Israels Hellige, som ifølge Jes 1,2 er deres far. Det nœere forhold mellem Jahve og folket, som dels kan beskrives som et pagtsforhold dels som et far-børn forhold, forpligter til lydighed. Men de har vist sig ulydige ved netop at forkaste, hvad Jahve kraver af dem.

Denne afsluttende anklage, v. 24, sammenfatter veråbenes forskellige anklager. Det, de har fortjent straf for, er netop ting, der strider mod Israels Helliges ord. Og som den hellige kan Jahve ikke lade som ingenting. Anklagen er bygget kiastisk op, så verberne indleder (hvis man i denne sammenhœeng ser bort fra det indledende כי) og afslutter udsagnet, hvorved de to parallelle udsagn om Jahves lov og Israels Helliges ord kommer til at stå i midten og dermed få scerlig vaegt.

Tilbage til indholdsfortegnelsen 


\section{Jes 5,25-30}

Tekstkritik

26a-a

Med henvisning til Jer 5,15 foreslås det i det tekstkritiske apparat, at flertalsformen, rettes til ental. I Jer 5,15 findes et tilsvarende udtryk i ental: לגוי ממרחק. Rettelsesforslaget haenger sammen med det andet forslag i det tekstkritiske apparat, BHSa, som går ud på at flytte v. 25-30 hen efter Jes 10,4, så det bliver indledning til et veråb rettet mod assyrerkongen. I den sammenhaeng ville entalsformen give bedre mening, da det så ville vare assyrerne, der var folket fra det fjerne. Der er dog ingen tekstvidner, der støtter rettelsen til ental i 26a eller flytningen af Jes 5,25-30. MT bør derfor beholdes, og teksten tolkes ud fra flertalsformen (se nedenfor).

\section{Karakteristik}

Sidste del af Jes 5 handler om Jahves fortsatte vrede mod folket. For at straffe dem vil Jahve sende deres fjender imod dem. Skildringen af fjenderne og deres fremmarch er malende, men holdt i generelle vendinger, ligesom det ikke er klart, om der med hans folk tcenkes på både Nordriget og Juda eller alene på Juda (jf. fokuseringen på Juda i Jes 5, 1-7). Udsagnet om at Jahves vrede endnu ikke har lagt sig kommer igen i Jes 9,11;9,16;9,20 og 10,4. Ordene fungerer som et konkluderende omkvœd, der samtidig peger videre mod nye udtryk for Jahves vrede. Sammenhœengen mellem Jes 5,25-30 og 9,7-10,4 brydes af Jesajas Denkschrift, der i sin nuvarende form omfatter Jes 6,1-9,6. Kombineret med veråbenes beskrivelse af folkets frafald fra Jahve skabes der en lang argumentationskœde, der skal overbevise lœseren om, at Guds folk har forsyndet sig i en sådan grad, at straffen ikke kan holdes tilbage. Den retfœerdige og hellige Gud kan ikke ignorere folkets synd, men vil nu gennemføre straffen ved hjœlp af folkets fjender.

Midt i denne kœde har redaktorerne placeret beretningen om Jesajas kaldelse samt tre eksempelfortcellinger, der skal vise, at Jahve grundlœggende ønskede at frelse sit folk, men frelsesbudskabet blev ikke modtaget. Folket - her reprcesenteret ved kong Akaz - forhardede sig. Og derfor kan Jahve endnu ikke ophøre med at straffe sit folk. Først i Jes 10,5, hvor vi møder endnu et veråb, œndrer situationen sig. For nu er veråbet vendt mod folkets hovedfjende, Assyrien, der ved sit hovmod har sat sig op mod Jahve og nu fortjener straf som forskyldt (se ncermere i analysen af Jes 
10,5-34). Og med straffen over Assyrien skabes der håb for Juda i form af en ny tid, med en konge af Davidsslœgten som hersker over et fredsrige, Jes 11,1-9.

Den redaktionelle sammenføjning af de enkelte orakler har først og fremmest som formål at skabe sammenhceng og mening i de historiske begivenheder, folket har oplevet. Bag begivenhederne står Jahve som den egentlige styrer af historiens gang og dermed også som garanten for, at intet er sket uden grund.

\section{Struktur}

25 Omkvœd om Jahves vrede og Jahves stadige trussel mod folket.

26-30 Trussel om Jahves mobilisering af fjenden fra det fjerne.

\section{Fortolkning}

\section{5}

Med dette vers ses der tilbage på Jahves vrede og de konsekvenser, den allerede har haft for hans folk, עמו. Omtalen af vreden viser, at man opfattede Jahve i lighed med en person. Samme forestilling ligger bag, når Jahves handlinger beskrives som noget, Jahve udfører med sin hånd. Ifølge v. 25 får Jahves vrede konsekvenser dels for naturen dels for byen og dens mennesker. At Jahves indgriben får bjergene til at ryste, רגז, minder om, hvordan Jahves blotte tilsynekomst kan få naturen til at reagere med rysten og skcelven, fx SI 18,8; 77,19; 99,1. Beskrivelsen af, hvordan ligene ligger henslcengt på gaderne som affald, tegner billedet af et krigerisk overfald, som har medført så mange døde, at de har fået lov til at ligge ubegravede hen. En mere uvœrdig død kan man ikke forestille sig (jf. hvordan Rispa beskyttede ligene af Sauls sønner og sønnesønner mod at blive cedt af vilde dyr og fugle, 2 Sam 21,10-14, samt hvordan dronning Jezabels lig blev kastet ned på gaden og spist af de omstrejfende hunde, 2 Kong 9,30-37).

Til trods for at Jahve har ladet sit folk lide store tab, er det ikke tilstrckkeligt. At Jahves vrede ikke har lagt sig endnu har som konsekvens, at der er mere i vente. Hans løftede hånd, ידו נטויה , viser, at Jahve har styrken til at handle og er parat til at gøre det. Den løftede hånd minder om det velkendte udtryk "med stcerk hånd og udstrakt arm", בזרוע נטויה, Deut 4,34; Deut 5,15; Deut 7,19; 1 Kong 8,42; SI 136,12; Ez 20,34. Men hvor Jahve de ncevnte steder griber ind og befrier sit folk, er den løftede hånd i Jes 5,25 vendt mod hans eget folk. 


\section{6-30}

Straffen over folket er i disse vers tydeligt beskrevet som et fjendeangreb ivœrksat af Jahve selv. Jahve optrœeder som hœerføreren, der rejser banneret for at samle sine krigere til kamp (jf. Jes 11,10.12). Som nœvnt ovenfor og som det er tilfœldet i DO 1992, foreslår det tekstkritiske apparat at rette folkene til ental: et folk. Formålet er at gøre det nemmere at identificere fjenden med Assyrien og dermed skabe en nœr forbindelse mellem dette afsnit og Jes 10,5-34. Spørgsmålet er dog, om ikke flertalsformen med sin manglende prœcisering er det rigtige på dette sted i argumentationsforløbet. Først bruges ubestemt flertal, der viser omfanget af truslen, og derpå entalsformer i suffikserne (fx han, dvs. Jahve, fløjter ad det, לי ויא), så fjenderne bliver til en samlet hœr. Det nœvnes ikke, hvem det er, Jahve har hidkaldt. Udtrykket, fra det fjerne, er netop uprœcist. I den forstand er det netop fjenden, sådan som fjender er til enhver tid, fremmede, der kommer udefra og uden at tøve overfalder ens land.

Som indledning til en rœkke vredesudsagn står beskrivelsen i Jes 5,25-30 retorisk stœrkt, når den ikke identificerer fjenderne, men blot betegner dem som folk fra det fjerne og beskriver, hvordan de er fuldt udstyrede og parate til kamp. Sådan går det, når Jahves vrede rammer det ulydige folk! At man så med erfaringerne om assyrerhœerens angreb i 701 f.Kr. i baghovedet vil tolke teksten om netop dette angreb er en anden sag.

Det er idealet af en hœr, der beskrives i v. 27-29. Men soldaterne beskrives som så "overmenneskelige", at det også skaber en vis uhygge. Soldaterne bliver ikke trœtte (i modscetning til fx hœren i Dom 8,4-5), de har ikke behov for at hvile sig og sove ${ }^{9}$ (i modsctning til 2 Sam 16,14), de løsner ikke bœltet, men er konstant klar til kamp, og selv sandalerne er i perfekt stand og sinker dem derfor ikke. Når man spœender bœeltet, gør man sig klar til kamp, Jes 8,9; men når man hviler, løsner man det. Sandalerne viser ligeledes, at soldaterne er klar til angreb (jf. Jos 9,13, hvor gibeonitterne viser deres nedslidte sandaler frem som tegn på, at de kommer langvejsfra og derfor ikke er nogen trussel for Josua).

Deres våben, bue og pil, er ligeledes kampklare, så de kan angribe når som helst. At hestenes hove er som flint angiver hårdheden. Ligesom sandalerne ikke er slidt, er hestenes hove heller

\footnotetext{
${ }^{9}$ I SI 121,4 bruges prœcis det samme udtryk, לא ינום לא יישן, men dér om Jahve som Israels hyrde og vogter.
} 
ikke slidt. De kan derfor løbe så hurtigt, at hjulene på de stridsvogne, de trckker efter sig, ligner hvirvelvinde.

Soldaternes brøl viser kamplysten. Deres kampråb, som skal indgyde modstanderne skrcek og radsel (jf. Jos 6,16.20), lyder, som når den rovgriske løvinde og alle ungløverne brøler under jagten, Am 3,8. Og ligesom løverne griber byttet og bringer det i sikkerhed for at fortcre det, således også med soldaterne. Deres overfald lykkes, og ingen kan redde de overfaldne.

Det afsluttende vers, v. 30, udvider igen perspektivet. Med udtrykket ביום ההוא, på den dag, knyttes der til ved traditionerne om den dag, hvor Jahve vil gribe afgørende ind (se faktaboksen om Jahves dag s. 78). Der er dog ikke her tale om en fjern fremtid. Soldaternes brølen ligner nu ikke blot løvernes knurren, men også havets knurren (verbet נהם bruges om begge). At havet optrœder truende giver associationer til de gammeltestamentlige kaosforestillinger; men hvor folket i SI 46 netop ikke frygter for vandets larmen og brusen, for Jahve skal nok redde dem, er konteksten en helt anden i Jes 5,30. Her ser kaos ud til at have taget magten, når landet er dakket af mørke, אור, , er blevet til mørke (jf. Job 3,4-5, hvor Job vender op og ned på skabelsesordenen ved at foretrcekke mørke frem for lys, samt skabelsen af lyset som modscetning til mørket i Gen 1,2-4). Lœst med skabelsesforestillingerne som intertekst får dette sidste vers som funktion at vise, hvor katastrofal den kommende ødelœggelse vil vœre for folket. Det skal vœre som dengang mørket endnu herskede over jorden.

Tilbage til indholdsfortegnelsen

\section{Jes 6,1-9,6}

\section{Karakteristik af Jesajas Denkschrift}

Jes 6, 1-9,6 (undertiden kun Jes 6,1-8,18) kaldes Jesajas Denkschrift eller Memoirer. Dette tilbageblik på Jesajas virke består af en rœkke episoder, der beretter om, hvorledes Jahve sendte Jesaja for at forhcerde folket, og hvordan Jesaja udførte sin opgave. De centrale dele går tilbage til tiden under den syrisk-efraimitiske krig (jf. ovenfor s. 25-26), mens en rœkke tilføjelser er udtryk for en senere fortolkning af budskabet. Gammeltestamentleren Odil Hannes Steck har fremsat den tese, at Denkschrift oprindelig bestod af 6,1-11;7,1-9.10-17; 8,1-8a.11-15.16-18, og at de tre episoder i Jes 7,3-9; 7,10-17 og 8,1-8a har som funktion at vise, hvordan profeten i praksis udførte det hverv, han fik pålagt i Jes 6,1-11, nemlig at forhcerde folket samt at vise, hvordan hans forkyndelse blev modtaget. I 
kap. 7, berettes det således, hvordan kong Akaz forhœrdede sig, så profeten talte for døve øren (se nœrmere i Kirsten Nielsen 1985, 233-234 samt Kirsten Nielsen 1989).

Det er vanskeligt at afgøre, om betegnelsen Denkschrift skal reserveres alene for Jes 6,1$8,18^{*}$ eller anvendes om hele Jes 6,1-9,6* ${ }^{10}$ For det sidste taler, at vredestemaet fra Jes 5,25-30 og ordene om, at Jahves vrede endnu ikke har lagt sig, genoptages i Jes 9,7-10,4 (se isœr omkvœdet i Jes 5,25; 9,1 1.16.20 og 10,4). Det er ligeledes påfaldende, at den rœkke af veråb, der begynder i Jes 5,8 og fortscetter i 5,1 1.18.20.21.22, først genoptages i 10,1.4. Dette kunne tyde på, at Denkschrift skiller en oprindelig sammenhceng ad.

Ikke desto mindre er der også gode grunde, der taler for at betragte Jes 6,1-8,18* som en afrundet enhed, der først sidenhen er blevet placeret i konteksten og bl.a. udvidet med oraklerne i Jes 8,17-9,6. Jes 6,1-11 fungerer som en prolog, der prcesenterer profeten og hans budskab. De tre episoder i Jes 7,3-9; 7,10-17 og 8,1-8a giver eksempler på, hvordan profeten fremsctter sit budskab i form af frelsesudsagn. Og endelig rundes Denkschrift af med en epilog, hvor profeten meddeler, at han nu afslutter sin forkyndelse ved at forsegle den hos sine disciple, Jes 8,16-18. Et trck, der er med til at understrege denne struktur, er motivet med profetens tavshed, der dels findes i Jes 6,5 (se nœrmere nedenfor om tolkningen af verbet דמה i betydningen tie stille) dels i Jes 8,16. Denkschrift begynder med, at den tavse profet får renset munden, så han kan tale, og slutter med, at profeten forsegler sit budskab og dermed tier.

Uanset hvordan man vil forklare tilblivelseshistorien bag den nu foreliggende komposition, er det vigtigt at vœre opmœrksom på, at de redaktorer, der har udvidet det oprindelige materiale, har gjort det som et led i deres tolkning af, hvad profeten Jesaja var sendt for at forkynde, og hvordan hans forkyndelse har kunnet forstås som relevant for redaktorernes samtid. I forskningen har der ofte varet en tendens til kun at betragte de dele af Jesajabogen, som har kunnet føres tilbage til den historiske Jesaja, som teologisk vigtige. Nyere forskning er dog langt mere indstillet på at se den fœrdige tekst som udtryk for teologisk refleksion. For da Jesajabogen blev endeligt redigeret, var det fx meget ncerliggende at tolke Denkschrift som forklaring på, hvorfor det gik så galt, som det gjorde, ikke blot i 8. årh., men også i 6. årh. f.Kr. Forsøgene på at afdckke tilblivelseshistorien skal derfor først og fremmest ses som bidrag til at forklare nogle af de ujœvnheder, som prœger den fœrdige tekst, fx

\footnotetext{
${ }^{10}$ Med * angives, at ikke alle vers i det pågceldende afsnit hører med til den oprindelige tekst.
} 
at mens Jes 6,1-11 er profetens gengivelse i første person af, hvad han så, og hvad han og Jahve sagde, så er de to sidste vers en uddybende kommentar holdt i tredje person.

Tilbage til indholdsfortegnelsen

\section{Jes 6,1-13}

\section{Tekstkritik}

$13 c-c$

I det tekstkritiske apparat gøres der opmœrksom på, at der i v. 13 mangler nogle ord i den grceske overscettelse, LXX (jf. BHSc-c). Formentlig har overscetteren af LXX sprunget ordene over, fordi ordet מצבת og versets sidste ord מצבתה ligner hinanden til forveksling. Teknisk kaldes det homoioteleuton (samme ende). DO retter ikke, da den hebraiske tekst giver god mening. Forslaget om at slette de sidste tre ord i v. 13 (jf. BHSf-f) er uden begrundelse og skal derfor heller ikke følges. I øvrigt forstår LXX billedet således, at det er agernet, der falder fra agernbageret og gengiver stedet: "som en terebinte, når agernet falder fra sit bœeger". En meget poetisk skildring af dommen, som også findes i den syriske overscettelse af dette sted (se ncermere i Kirsten Nielsen 1985, 241-242).

\section{Karakteristik}

Kapitel 6 indeholder beretningen om Jesajas vision i templet i Jerusalem, hvor han fik sin scrlige opgave betroet af Jahve. Forskerne betegner enten Jes 6 som en kaldelsesberetning eller som en sendelsesberetning. Genremœssigt har man inden for forskningen skelnet mellem to typer af kaldelser. I den ene er det Jahves ord, der er det dominerende, fx ved kaldelsen af Moses, Ex 3, af dommeren Gideon, Dom 6, og af profeten Jeremias, Jer 1. Om alle tre galder, at de i første omgang vagrer sig mod kaldet og henviser til, at de ikke er egnede til at påtage sig så stor en opgave. I den anden type er det visionen, der dominerer, fx i 1 Kong 22,19-23, hvor en profet, Mika Jimlas søn, ser Jahve omgivet af sin rådsforsamling, samt i Jes 6, hvor Jesaja ser Jahve som konge omgivet af serafer. I begge tilfœelde er der tale om udsendelsen af et guddommeligt sendebud (se også den valdige vision i Ez 1-3). Men selv om visionen dominerer i begyndelsen af Jes 6, er det budskab, profeten sendes med, afgørende for det videre forløb. Skal man forstå det scerlige ved Jes 6, må man derfor se teksten i lyset af begge typer af kaldelsesberetninger. Og netop i den sammenhœeng er det påfaldende, at beretningen om kaldelsen af Jesaja i modscetning til fx Jer 1 og Ez 1-3 ikke er placeret for- 
rest i Jesajabogen (se også Jes 40, hvor der finder en udsendelse sted som indledning til den deuterojesajanske forkyndelse).

Kaldelsesberetninger har som funktion at legitimere den pågœldende som Guds udsending og dermed forkyndelsen som Guds og ikke profetens egne ord. Derfor vil en placering i begyndelsen af et profetskrift vœre det naturlige. I Jesajabogen er det anderledes. Årsagen må findes i redaktorernes ønske om at give en begrundelse for det scerlige indhold af Jesajas opgave: forhcrdelsen af folket. Hvis denne opgave var blevet pålagt Jesaja uden de indledende kapitlers påvisning af folkets og ledernes frafald fra Jahve, ville Jahve fremstå som en utilregnelig despot, der blot skaltede og valtede med sit eget folk. De første fem kapitler kommer derfor til at fungere som bevis for, at folket selv var skyld i, at det var nødvendigt at straffe dem. De var nemlig uimodtagelige mod den forkyndelse, som ellers skulle have givet dem al mulig grund til at vende tilbage til Jahve. Den store vanskelighed i Jes 6 er dog, at denne uimodtagelighed over for forkyndelsen beskrives som et formål med forkyndelsen. Jesaja er netop sendt for at forhcerde dem, så de ikke vender om, og Gud helbreder dem.

Forskernes skelnen mellem kaldelsesberetning og sendelsesberetning er med til at tydeliggøre, hvad der er det specielle ved Jes 6,1-13. Ud over at beretningen, som ncevnt, ikke er placeret forrest i Jesajabogen, er den forbundet med en scerlig politisk situation. I den forstand er der god grund til at tale om en scerlig opgave, som profeten sendes ud med. Når det alligevel er relevant at fastholde, at der også er tale om en kaldelse, skyldes det, at Jes 6,1-13 på linje med andre kaldelsesberetninger har som funktion at legitimere profetens forkyndelse. Jesajas profetier er ikke hans egne ord, men de ord han er kaldet til at sige. Netop derfor blev hans mund renset. Jes 6,1-13 kombinerer således aspekter fra begge typer af beretninger om Guds kaldelse og udsendelse af en profet.

Når nogle forskere foretrckker betegnelsen sendelsesberetning, hœenger det desuden sammen med, at de ser forhcerdelsesopgaven som en speciel del og ikke som en overordnet bestemmelse af profetens samlede virke. Forhcerdelsesopgaven er forbundet med netop Denkschrift og perioden omkring den syrisk-efraimitiske krig.

Endelig er der forskellige opfattelser af, om v. 12-13 eller dele af disse vers hører med til selve beretningen, eller der er tale om senere tilføjelser (se ncrmere nedenfor).

\section{Struktur}


1-4 Jesajas syn: Jahve på tronen i templet.

5-7 Jesajas selvanklage og renselsesceremonien.

8-10 Jahves kaldelse af Jesaja, Jesajas svar, sendelsens formål: forhcerdelsen.

11-13 Jesajas spørgsmål om forhœrdelsens varighed, Jahves svar: fuldstcendig ødelceggelse men dog en stub tilbage.

\section{Fortolkning}

$1-4$

Visionen dateres til kong Uzzijas dødsår, dvs. 744 f.Kr. Ud over at angive et bestemt årstal kan omtalen af dødsåret også markere noget andet. Den jordiske konge dør, men hvad profeten oplever, er at se den himmelske konge sidde på sin trone (se også kommentaren til Jes 7,9, hvor netop Jahve skal forstås som Judas egentlige konge). Folket er altså ikke uden konge, så løenge Jahve troner på Zion. I god forlcengelse af Jes 2,1 1.17, hvor Jahve omtales som den, der alene er ophøjet, beskrives tronen her i Jes 6,1 som ophøjet.

Som det fremgår af profetens reaktion i v. 5, er det ikke ufarligt for et menneske at se Gud selv. Modscetningen mellem det guddommelige og det menneskelige fremhceves ofte i Det Gamle Testamente og fremgik også klart af modstillingen i Jes 2 mellem Jahve og menneskenes verden. En beretning, der pointerer det umulige i, at et menneske kan se Gud, findes i Anden Mosebog, hvor Moses anmoder om at se Jahves herlighed, Ex 33,18-23, men får svaret: "Du får ikke lov at se mit ansigt, for intet menneske kan se mig og beholde livet."

Synet af Herren (Jahve omtales her med betegnelsen אדני) er således ikke kun en positiv begivenhed, det er også forbundet med fare. Netop derfor er det vigtigt, at måden, der fortclles om visionen på, viser, at der er grcenser for, hvad profeten får at se. For straks efter nœvnes det, at slœbet på den guddommelige konges dragt fylder hele templet. I profeten Ezekiels kaldelsesvision findes også en beskrivelse af, hvordan profeten ser Herrens herlighed. Men pracis hvordan den tronende guddom ser ud, siges ikke. Der siges meget om omgivelserne, men om den skikkelse, der sidder på tronen, hedder det, at "der var noget, der lignede og så ud som et menneske" og videre skildres det, hvordan noget, der ligner funklende hvidguld og ild, udgik fra det, "der så ud som hans hofter", og det lignede Herrens herlighed, Ez 1,26-28. Selv i visionen kommer profeten ikke tcet på Gud, men aner noget, der kun kan beskrives med et vald af sammenligninger. 
I v. 2 uddybes scenariet. Omkring den guddommelige konge står der serafer, som hver iscr er udstyret med seks vinger. Serafer er himmelske vœesener. Navnet er afledt af verbet, שרך, der betyder at brcende. De er opfattet som lysende vœsener, der har vinger og derfor kan holde sig svœvende omkring tronstolen. Vingerne bruges desuden til at beskytte sig selv med, når de ved at tildœkke ansigtet undgår at se Gud, samt til at skjule underlivet med (den hebraiske glose רגלים, der betyder fødder, er en eufemisme for kønsdelene). At det er nødvendigt at skjule kønsdelene, når man er $\mathrm{i}$ ncerheden af det hellige, kendes også fra reglen om, at prcesterne ikke må gå op til alteret ad trin, da deres køn i så fald kunne blive blottet over alteret, Ex 20,26. Det må derfor vœre Gud selv, der skal beskyttes mod synet af kønsdelene.

Seraferne er blandingsvaesener. De hører både til dyreverdenen og til menneskeverdenen. De har vinger, og de kan tale (jf. blandingsvcesnerne i Ez ${ }^{11}$ ). Talen er en lovsang, der netop understreger Guds hellighed. Det trefoldige hellig, hellig, hellig, som genbruges i Folkekirkens nadverritual, er rettet til Hœerskarers Jahve, יהוה צבאות. I Folkekirken og i DO 1992 gengives navnet dog som Hœrskarers Herre.

\section{Faktaboks: Haerskarers Jahve}

Betegnelsen Hœrskarers Jahve anvendes mere end 250 gange i Det Gamle Testamente. Betegnelsen er forbundet med forestillingerne om Jahve som en guddommelig kriger, der er herre over store hœre og derfor er i stand til at overvinde folkets fjender. I Deboras Sang indgår stjernerne i disse hœerstyrker, Dom 5,20, mens det i SI 103,20-21 er englene, der fungerer som krigere i den himmelske hœr. Selve betegnelsen Hœrskarers Jahve kendes fra forestillingerne om Pagtens Ark i Silo, hvor det siges, at Hœrskarers Jahve troner på keruberne, 1 Sam 4,4. Det er da også arken, der går i spidsen, når de drager ud i krig (se Num 10,35, hvor Moses under ørkenvandringen, når arken brød op, opfordrede Jahve til at rejse sig, "så dine fjender spredes og dine modstandere flygter for dig!"). Hcerskarers Jahves hcer omtales i Jes 13,4 som en hcer, der skal kœmpe mod Babylon, og som samles fra et land i det fjerne. Sammen med helligheden hører Guds styrke, sådan som tilnavnet Hœrskarers Jahve angiver det. Endelig ncevnes Jahves herlighed. Glosen כבוד betegner Jahves udstråling og glans. Det kan også indbefatte Jahves magt og anseelse, SI 102,16. Her i v. 3 ligger vagten på omfanget. Hele jorden er omfattet af Jahves magtfulde ncervcr.

\footnotetext{
${ }^{11}$ Se nœrmere i Kirsten Nielsen 2006 om sammenhœengen mellem det guddommelige og blandingen af kategorier som dyr og menneske.
} 
I v. 4 beskrives følgerne af ncervœret. Tempelbygningen reagerer ved at ryste, ganske som mennesker kan gyse ved mødet med Gud, SI 48,6-7, og jorden forfcrdes, SI 97, 1-5. At huset fyldes med røg kan tolkes som en del af de traditionelle forestillinger om, at ild og røg hører med til Guds tilsynekomst, SI 18,8-9. Lœst i forlœengelse af v. 1, hvor det nœvnes, at slœbet fylder templet, kan røgen også ses som et slør, der skjuler Gud for det menneskelige øje. Hertil kommer at røgen kan ses som en forudgribelse af omtalen af alteret, Jes 6,6.

\section{$5-7$}

Visionen skaber også angst hos profeten og fører til, at Jesaja anklager sig selv for at have urene lœber. Jesajas udbrud er formet som et veråb, der markerer det dødsensfarlige i situationen. I den danske overscettelse gengives verbet med udtrykket "det er ude med mig". Men verbet נדמית er nifal enten af דמה II: tie stille eller af: blive tilintetgjort. ${ }^{12}$ Ud fra en vurdering af tekstens kontekst er der grund til at foretrckke overscettelsen tie stille. Fokus er i v. 5 netop på profetens lceber. Det er deres urenhed, der hindrer, at han kan påtage sig det hverv, han efter renselsen sendes ud med. At lœberne eller munden er det centrale ved en profet, fremgår også af kaldelsen af profeten Jeremias, Jer 1,9, hvor Jahve rører ved hans mund og lagger sine ord i den. Det samme gœlder Ezekiels kaldelsesberetning, hvor profeten får besked på at sluge forkyndelsen i form af en bogrulle, Ez 3, 1-3. Endelig skal det nœvnes, at i afslutningen på den korte udgave af Denkschrift genfindes motivet med at tie, når der skal lukkes til for forkyndelsen, Jes 8,16-18 (jf. også motivet profetens stumhed i Ez $3,26)$.

Urenheden er ikke alene forbundet med profeten selv, men også med folkets urenhed. Renselsen betyder derfor også, at han tages ud af det urene folk og kan få en opgave over for folket. Over for alt det urene står da Jahve. Jahve er i v. 3 karakteriseret både som Hœrskarers Jahve og som den hellige. Hellighed og urenhed er modsctninger. Derfor må Jahve selv gribe ind og fjerne det, der står i vejen for udsendelsen af Jesaja.

I v. 6 skildres det, hvordan dette sker ved hjœlp af en af seraferne. Det gloende kulstykke renser urenheden bort. Forestillingerne om renselse ved hjœlp af ild kendes iscer i forbindelse med renselse af metal, Num 31,22-23. I Mal 3,3 findes en skildring af, hvordan Gud renser levitterne med ild, lige som man lutrer sølv og guld (jf. gendigtningen i B.S. Ingemanns salme "Den store mester

12 Jf. Köhler und Baumgartner, Hebräisches und aramäisches Lexikon zum Alten Testament. Se også Kirsten Nielsen 1989, hvor jeg har argumenteret for betydningen "tie stille". 
kommer", hvor mesteren "sidder ved smeltediglen / og lutrer sølvet med flid.", DDS 612). Herefter er urenheden fjernet, og profeten er i stand til at tale på Jahves vegne. At renselsen finder sted $\mathrm{i}$ templet understreges af, at kulstykket hentes fra alteret. Der er her tœnkt på røgelsesalteret, som befinder sig inde i templet, Ex 30,27; 31,8.

Efter at have berørt netop løeberne formulerer serafen betydningen af handlingen: Skylden, עון, er nu fjernet fra Jesaja, og hans synd, חט, er sonet. At ydre handlinger kan sone synd kendes også fra SI 51,9, hvor det er ysop, der bruges til at fjerne synden med (verbet af synd). Verbet sone, כפר, bruges her synonymt med at rense. Tanken om renselse kendes i øvrigt fra ritualet ved den store forsoningsdag, hvor helligdommen renses med blod. Grunden til at helligdommen skal renses er, at den er blevet forurenet gennem folkets synder (se Lev 16 om forsoningsdagen). Renselsen er nødvendig, for at Jahves herlighed, כבוד, kan vœere til stede i helligdommen (jf. Ez 10,18-22, hvor Jahves herlighed forlader templet p.g.a. afgudsdyrkelsen).

\section{8-10}

Med v. 8 følger Jesajas beskrivelse af, hvad der følgende skete. Han hører Herrens røst, קול ארני.

Serafens opgave er afsluttet, og nu er det Gud selv, der tager ordet og spørger, hvem han kan sende (jf. overvejelserne over, om Jes 6 skal forstås som en sendelsesberetning), og hvem der vil gå bud for ham. Scenen minder om 1 Kong 22,20, hvor Jahve spørger, hvem der vil påtage sig opgaven at lokke kong Akab til at gå i krig, så han falder i slaget ved Ramot i Gilead. En af himlens hcr melder sig da og lover at blive en løgneånd i munden på profeterne.

I modsœtning til en profet som Jeremias, der vœegrer sig mod kaldelsen, Jer 1,6 (se også Ex 3 om Moses, og Dom 6 om Gideon), melder Jesaja sig uden forbehold med et "Her er jeg!" Baggrunden er renselsen, der har fjernet urenheden og dermed hindringen for at profetere.

I v. 9 indleder Jahve sin tale til Jesaja med en imperativ: לך, "Gå!" Dette svarer til andre beretninger om, at en herre sender et sendebud af sted (jf. fx 2 Sam 18,21, hvor Joab sender et sendebud af sted til kong David). I Gen 12,1 henvender Jahve sig til Abram med en tilsvarende imperativ, לד, der kort efter, v. 4, følges op med wajjiqtol formen af samme verbum, וילך. Hermed markeres den totale lydighed fra Abrams side. Jahve befaler "Gå!", og Abram går som befalet. I Jes 6 er der ikke en sådan følgescetning. Jesajas beredvillighed til at lade sig sende bliver ikke fulgt op med et udsagn om, at han drager ud. For sammen med befalingen til at gå kommer en ncermere bestemmelse af opgavens art. At han skal tale på Jahves vegne er der intet overraskende i. Lœberne er af den 
grund netop gjort rene. Men indholdet er overraskende. Profeten skal opfordre folket til at lytte og se, men samtidig får hans tilhørere at vide, at de ikke skal fatte og forstå det, de hører og ser.

Formålet med en profets ord er under normale omstcendigheder, at tilhørerne forstår, hvad der er Guds vilje og retter sig derefter. Budskabet skal opfattes og få konsekvenser for tilhørernes liv. Formaninger og trusler om straf har fx til formål at få folk til at œndre adfœrd. Formålet er tydeligvis ikke positivt, når det her siges direkte, at forkyndelsen skal vœre resultatløs. Den negative tone forudgribes, når Jesajas samtidige på distancerende vis kaldes dette folk og hverken mit folk Israel eller Jakobs hus. Det er påfaldende, at ordene i v. 9 ikke indeholder noget budskab, men snarere er en oplysning om, hvordan forkyndelsen vil falde ud: Profetens landsmœend vil ikke høre efter (jf. Ez 3,4-9; Jer 1,17-19). Man kan derfor diskutere, om ordene ikke mere er henvendt til Jesaja end til hans tilhørere, selv om de formelt er henvendt til folket (2. person pluralis).

Under alle omstcendigheder er v. 10 henvendt direkte til Jesaja. Hans opgave består i at forhindre folket i at forstå budskabet, så de ikke omvender sig. For gjorde folket det, så ville Jahve naturligvis frelse dem. Verbet helbrede, אר, skal forstås ud fra billedet af en syg person (jf. Jes 1,5-6), der har brug for helbredelse. Hvis folket vendte sig til Jahve og bad om hans tilgivelse, ville han ikke kunne afvise dem.

Profeten skal med andre ord forhcerde folket på Guds vegne. Forestillingen om, at Gud selv forhindrer mennesker $i$ at rette sig efter hans ord, kendes også fra beretningen om Farao, der forhcerder sig over for Moses, da denne beder om tilladelse til at føre sit folk ud i ørkenen, så de kan tilbede deres Gud. Faros forhcrdelse indgår i Guds planer og er villet af Gud (se fx Ex 7,3-5 og 10,1). Ved hjœlp af en rœkke billeder tydeliggøres det, at folket ikke skal tage forkyndelsen til sig. Hjertet, som er scede for fornuften og viljen, skal dcekkes til med fedt, så intet trcenger ind. Ørerne skal gøres tunge, så de ikke kan høre med dem. Og deres øjne skal profeten lukke til, så de ikke kan se. De tre parallelle udtryk forstœerker budskabet: Folket er ude af stand til at forstå noget (jf. anklagen mod børnene i Jes 1,3, hvor folket dog blev omtalt som עמי, dvs. som mit folk).

At folket skal forhcrdes skyldes, at de ellers kunne omvende sig og derigennem undgå den straf, som Jahve har truet med. Netop i forlcengelse af de mange trusler og domsorakler i de indledende kapitler giver forhcerdelsestanken mening. Straffen er og bliver uundgåelig, men folket barer selv skylden for det. Havde planen om at forhcerde folket ikke vœret en konsekvens af folkets frafald fra Jahve, ville Jahves beslutning vœre uforklarlig. Det har derfor vœret vigtigt for redaktorerne at placere sendelsen af Jesaja efter anklagerne for frafald. 
Det fremgår ikke af v. 9-10 hvad profeten rent faktisk skal sige. Det egentlige indhold kommer først i de tre episoder, der fortclles om i kap. 7-8 (se ncermere nedenfor).

\section{$11-13$}

I kapitlets sidste afsnit spørger Jesaja, hvor lœenge denne forhœrdelsestilstand skal vare. Profeten spørger ikke om selve indholdet af forkyndelsen. Det er underforstået, at når folket ikke vil lytte til sin Gud, så må Gud straffe det. Problemet er derfor ikke, hvad der skal ske, men hvor laenge det skal vare, før Jahve griber ind og helbreder sit folk.

Et sådant spørgsmål om varighed kendes også fra de gammeltestamentlige bønssalmer (klagesalmer). I SI 13 indleder salmisten sin klage med ordene "Hvor lœenge vil du dog glemme mig, Herre? Hvor lœenge vil du skjule dit ansigt for mig?", SI 13,2. Jesajas reaktion skal forstås på samme måde. Han lider med sit folk (jf. v. 5, hvor han solidariserer sig med sit folk), og håber, ligesom salmisten, at Jahve snart vil gribe ind og cendre situationen. Formålet med en bønssalme er at få Jahve til at forbarme sig og hjœlpe den nødlidende. Men hvor en del bønssalmer slutter med en tak, fordi Gud har grebet ind, fx SI 22,22b-32, bliver Jesajas klage ikke efterfulgt af Jahves indgriben. Tvœrtimod skal den negative situation fortscette. En af de funktioner, en profet kan have, er at gå i forbøn for sit folk (jf. fx Am 7,1-9, hvor Jahve to gange lader sig påvirke af profetens forbøn for folket, men tredje gang afviser at tilgive folket), men i Jes 6 bliver det kun til det klagende spørgsmål "Hvor lcenge, Herre?".

Hvad straffen består i fremgår klart af anden del af v. 11, hvor beskrivelsen af de øde byer og det øde land må forstås som et resultat af fjendernes hœrgen. Jahve vil overlade sit folk til dets fjender (jf. truslen om fjendeangreb i Jes 5,25-30 + 9,7-10,4). Når Jahve er passiv, så får fjenderne magten.

Det omfattende i katastrofen fremgår af, at ikke blot byerne som helhed, men også de enkelte huse, de mindste dele af samfundet, skal vare mennesketomme. Og som konsekvens heraf vil markerne ikke lcengere blive dyrket, men ligge hen som ørken (jf. Jes 5,5-6). Kosmos omdannes til kaos. At det er Jahve, der står bag ødelœeggelsen, siges direkte i v. 12. Men det hindrer ikke, at hans redskab er folkets fjender (jf. omtalen af Assyrien i Jes 10,5-6). Den historiske situation, der svarer til skildringen af det tomme land, er deportationen af dele af befolkningen fra Nordriget i 722 f.Kr., 2 Kong 17,6. Verbet רחק bruges i Jer 27,10 og Ez 11,16 ligeledes om deportation, selv om den tekniske 
term er verbet גלה. At der i v. 12 primœrt tcenkes på deportationen af befolkningen i Nordriget (Israel), fremgår af v. 13.

Med v. 13 uddybes truslen om den totale ødeløggelse. Muligheden af at en tiendedel skulle gå fri i første omgang må forstås sådan, at ødelaeggelsen vil ramme Nordriget. Men derefter vil også Juda (Sydriget), der i modsctning til Nordriget kun omfatter en enkelt stamme og derfor meget vel kan betragtes som kun en tiendedel af storriget, også blive ramt. Meddelelsen om Nordrigets undergang, 722 f.Kr., må i første omgang have medført en vis lettelse i Juda. Under den syrisk-efraimitiske krig, 734-732 f.Kr., havde Nordriget (Efraim) vendt sig mod Juda og forsøgt at tvinge det med i en koalition mod Assyrien. Nu viste det sig, at et opgør mod Assyrien fik katastrofale følger, og der var god grund til at vœre tilfreds med, at man ikke havde fulgt Nordrigets eksempel. På den anden side har erobringen af Nordriget bragt assyrerne endnu ncermere Judas territorium, hvilket alt andet lige kun kunne opfattes som en trussel mod Judas selvstcendighed (jf. også at kong Akaz if. 2 Kong 16,78 havde bedt assyrerkongen om hjœelp og var blevet nødt til at betale en stor tribut). På denne baggrund skal man forstå truslen mod Juda i v. 13 (se også Jes 5,7, der omtaler både Israel og Juda). Profeten har forkyndt, at hans landsmœnd ikke skal føle sig sikre, straffen rammer også dem.

Ødelaggelsen angives med verbet בער (piel), der kan betyde enten afbrcende eller afgnave. Til fordel for den sidste betydning taler brugen i Jes 3,14 og 5,5. ${ }^{13}$ At ødelceggelsen ikke udelukker en mulig fremtid fremgår af det følgende, hvor der tages et vist forbehold. Ved hjœelp af billedet af det fœldede trœ, hvis stub er hellig sced, modificeres domsoraklet. Nok skal Juda udscettes for en alvorlig ødelceggelse; men der er stadig håb for fremtiden.

Motivet trœefœldning går igen i Jes 10,33-34, hvor det efterfølges af et frelsesorakel. Selv om de store trœeer fœeldes, skal der skyde et nyt skud frem af Isajs stub, Jes 11,1. Denne kombination af doms- og frelsesorakler er karakteristisk for Jesajas forkyndelse. Dommen er uundgåelig, men der skal trods alt blive en rest tilbage, som overlever.

De nœvnte trœer, terebinte og eg, betragtes som sœeligt stcrke trœer, men hvor konnotationerne i Jes 1,29-31 er negative, er de her positive. Nok fœldes trœerne, men der bliver en stub tilbage. Trceer forbindes i Det Gamle Testamente med frugtbarhed og livskraft. I Jobs Bog beskrives trœer som mere livskraftige end mennesker. Derfor kan Job sœtte det livskraftige trœ op som mod-

\footnotetext{
${ }^{13}$ Se ncermere i Kirsten Nielsen 1985, 141, hvor jeg behandler den mulige reinterpretation af stedet.
} 
pol til det dødelige menneske, der kun lever en kort tid. Nok er der håb for et trœ, selv om det fœeldes, og rødderne bliver gamle, bare det får vand.

Men dør en mand, er det forbi med ham,

udånder et menneske, hvor er det så?

Job 14,10.

I SI 1,3 bliver det retfcerdige menneske sammenlignet med et trœ, der er plantet ved bœkken og derfor bcrer frugt til rette tid. I Jes 6,13 anvendes billedet af trœet ligeledes positivt. Stubben ${ }^{14}$ indeholder nye muligheder. Det er almindelige erfaringer fra planteverdenen, som her bruges til at overbevise tilhørerne/lœeserne om, at ikke alt håb er ude, selv om trœet fœldes. Yderligere understreges håbet, når spirekraften i stubben kaldes hellig, dvs. den hører Gud til.

Hvad der prœcis tœnkes på m.h.t. den hellige spirekraft (sœd) kan ncppe afgøres endeligt. Men set i relation til den tilsvarende billedbrug i Jes 10,33-11,1 er det sandsynligt, at det er Davidsdynastiets overlevelse. Trods sin kritiske holdning til kong Akaz, Jes 7, fastholder Jesaja således sine positive forventninger til en kommende konge, Jes 9,5-6; 11,1-9.

Vers 13 bliver af mange betragtet som en senere tilføjelse, da det synes at stride mod hovedtanken i kapitlet i øvrigt, når domsforkyndelsen ender med et billede, der skaber håb. Det er ikke muligt at afgøre, om verset går tilbage til Jesaja selv, men som Jes 1-12 nu foreligger, må man betragte også v. 13 som en genuin del af den forkyndelse, som redaktionen har tillagt Jesaja. Man har ikke opfattet Jesaja alene som en domsprofet, men som en profet, der nok skulle viderebringe Jahves trusler om straf, men også holde et spinkelt håb levende. Og netop dette så man underbygget af begivenhederne ved belejringen af Jerusalem i 701 f.Kr., hvor størstedelen af Juda blev erobret af assyrerkongen Sankerib, men Jerusalem selv gik fri.

Dobbeltheden i den jesajanske forkyndelse fandt sin bekrceftelse i de politiske begivenheder, som fandt sted i forbindelse med Nordrigets undergang i 722 f.Kr. og ved belejringen af Jerusalem i 701 f.Kr. Men forkyndelsen har også vœret af afgørende betydning for tolkningen af den virkelige katastrofe for Juda, da babylonerne erobrede og ødelagde Jerusalem og førte folket i eksil i Ba-

\footnotetext{
${ }^{14}$ Glosen for stub, מצבה, kan vœkke associationer til de hellige masseber, der dog er af sten og ikke af trœ. Men set i lyset af Jesajas polemik mod afgudsdyrkelse, er det nœppe tanken her.
} 
bylon i 587 f.Kr. I den situation har den jesajanske domsforkyndelse fungeret som forklaring på ulykken og oraklerne om en fremtid for en rest har kunnet danne basis for et fornyet håb til fremtiden.

Tilbage til indholdsfortegnelsen

\section{Jes 7,1-9}

\section{Tekstkritik}

Der er ingen grund til at rette i teksten.

\section{Karakteristik}

Beretningen om aramceerkongen Resins og Israels konge Pekas forsøg på at tvinge den judceiske konge Akaz med i en koalition mod assyrerkongen er en af tre eksempelfortcellinger, der skal vise, at Jesajas forkyndelse førte til forhcerdelse. De tre episoder, Jes 7,1-9; 7,10-17 samt 8,1-4, viser alle eksempler på frelsesforkyndelse. Forhcerdelsen er dermed reaktionen på en forkyndelse, som kongen burde have taget imod med gløede. At kongen ikke tror profeten betragtes derfor som så urimeligt og stridende mod alt, hvad man måtte forvente af Jahves konge, at det kun kan forklares som udtryk for Jahves plan med Juda. At denne plan så igen har sin baggrund i folkets og ledelsens manglende tillid til Jahve fremgår af placeringen af kap. 1-5 som optakt til beslutningen om at sende Jesaja med den scrlige opgave at forhœrde folket. Gennem profeten Jesaja forkynder Jahve, at der ikke er grund til at frygte for de to konger, der truer Juda. Men kong Akaz tør ikke tro det gode budskab og vœlger i stedet at støtte sig til assyrerkongen (jf. hans henvendelse til assyrerne om hjœlp i 2 Kong 16,7 og se ncermere om den politiske situation i afsnittet om den politiske udvikling fra 740'erne til 701 f.Kr., s. 25-27). Beretningen har som forudscetning, at lceserne kender den gammeltestamentlige forestilling om, at selv om fremmede konger angriber Jerusalem og truer med at erobre byen, så vil Jahve frelse sin by. Denne folkekampmyte findes i SI 46, som er en Zionsalme, og ligger også bag SI 2, hvor fjendernes oprørsplaner kun vœkker Jahves hånlatter (se nœrmere i DKDS II i kommentaren til de ncvnte salmer). Troen på Zions uindtagelighed er et vigtigt element i Zionteologien og burde have fået kong Akaz til at sctte sin lid til Jahve og ikke til en jordisk storkonge som assyrerkongen. Jesaja betragter ganske enkelt politiske koalitioner og anden politisk-militcer virksomhed som udtryk for vantro. 


\section{Struktur}

1-2 Den udenrigspolitiske situation: Aram og Israel truer med at erobre Jerusalem.

3 Jahves befaling til Jesaja om sammen med sin søn Shearjashub at møde kong Akaz.

4-6 Trøstende orakel, der skal gengive Akaz modet.

7-9 Betinget frelsesorakel, der formaner til tillid til Jahve.

\section{Fortolkning}

\section{$1-2$}

Beretningen omhandler begivenheder under den syrisk-efraimitiske krig, 734-732 f.Kr. Navnet syriskefraimitisk hentyder til de to konger, der går i krig mod Juda. Syrien er et andet navn for Aram, og Efraim bruges her om Israel, dvs. Nordriget. Akaz er konge over Juda, dvs. Sydriget. Han regerer i perioden 736-715 f.Kr. og beskrives i 2 Kongebog 16 som en konge, der ikke gjorde, "hvad der var ret i Herren hans Guds øjne, sådan som hans fader David gjorde", 2 Kong 16,2. Deuteronomisternes negative skildring af kong Akaz modsvares af en tilsvarende positiv beskrivelse af hans søn og efterfølger kong Hizkija, 2 Kong 18-20. Denne noget skematiske opfattelse af Judas historie findes også i Jesajabogen, dels i Jes 7-8, dels i omtalen af Hizkija i Jes 36-39, hvor kong Hizkijas reaktion på assyrerkongen Sankeribs angreb på Jerusalem i 701 f.Kr. opstilles som en klar modsœtning til kong Akaz' reaktion under den syrisk-efraimitiske krig, Jes 7,1-9.

Formålet med belejringen er at tvinge Akaz til at gå med i et oprør mod assyrerkongen, som de begge betalte skat til, men ønskede at frigøre sig fra. I modscetning til Resin og Peka er Akaz endnu ikke underlagt assyrerkongens myndighed og har derfor ikke den samme interesse i at vende sig mod assyrerne.

Straks fra begyndelsen anføres det, at de to konger ikke vil vœre i stand til at erobre Jerusalem. Dette svarer såvel til den historiske virkelighed som til Zionteologiens understregning af, at Jerusalem ikke kan erobres, fordi den er Jahves by og stedet, hvor Jahve har indsat sin konge, SI 2,6. Som lœeser er man derfor ikke i tvivl om, at Jahve lever op til sine løfter om at beskytte Jerusalem. Derfor virker beskrivelsen af kongens og folkets reaktion som en klar markering af deres manglende tillid til Jahve. Arams konge er endnu ikke nået lœengere end til Nordriget, men alligevel gribes alle i Juda af skrœk. Rœdslen beskrives gennem billedet af trœerne, der skœlver i vinden. Jesaja bruger her endnu engang trœet som billede. I Jes 1,29; 2,13 og 6,13 er trœerne beskrevet som store og stcrke; ikke 
desto mindre kan Jahve når som helst bringe skam over trceerne og faelde dem. I Jes 7,2 er det deres svaghed i forhold til vinden, der understreges. Glosen for vind, רוח, betyder også ånd. I SI 1 bruges trœet som billede på det retfœrdige menneske, mens den ugudelige er som avner, der blœses bort af vinden, רוח, SI 1,4. I SI 1 er der nœppe tvivl om, at bag den vind, der fjerner avnerne, står Gud selv (jf. Gen 1,2, hvor רוח både kan betyder vind og ånd). Det er ikke helt klart, om der i Jes 7,2 er en antydning af, at bagved begivenhederne står Jahve og fører sin plan igennem, nemlig at forhcerde kongen og folket. Under alle omstcendigheder vil tekstens forfatter nceppe hermed frikende Akaz for hans manglende tillid til Jahve. Det kan virke selvmodsigende, men uanset Jahves planer, så er kongen og folket ansvarlige for deres reaktion, ligesom det er tilfœldet i kap. 1-5.

At det er hjertet, der skcelver, betyder, at det er deres vilje og dermed deres mod, der svigter.

\section{3}

Selve sendelsen af profeten indledes med en angivelse af, at det er Jahve, der henvender sig til Jesaja. Beretningen er holdt i tredje person i modsctning til Jes 6, der fremstår som profetens egen beretning i første person. Forskerne har diskuteret, om dette er et tegn på, at beretningen ikke går tilbage til Jesaja selv, men det er nceppe muligt at skelne skarpt mellem, hvad hans disciple har formuleret, og hvad der kunne vare profetens egne ord. Derimod giver brugen af tredje person mulighed for at anføre profetens navn: ישעיהו. Navnet betyder Jahve frelser og kan her fungere som en markør af budskabet: Jahve ønsker at frelse sit folk fra dets fjender. Det tekstkritiske forslag, BHSa-a, om at rette til אלי (til mig) ville derfor betyde, at denne pointe gik tabt. Formålet med forslaget er at gøre beretningen til en førstepersonsberetning i stil med kap. 6, men der er ingen tekstbelœg for rettelsen. Rettelsesforlaget er et eksempel på forskningens forsøg på at harmonisere teksterne, men teksten skal beholdes i den nuvœrende form.

Jesaja skal gå ud og møde kong Akaz. At Jesaja skal tage sin søn med skal også forstås som en angivelse af, hvad budskabet går ud på, (nomen est omen, navnet er et varsel). Sønnens navn er et symbolnavn. שאר ישוב betyder: En rest vender tilbage, eller en rest vender om. Verbet שוב kan bruges som en neutral betegnelse for at vende tilbage til det sted, man drog ud fra, dvs. rent geografisk (se fx Gen 14,7); men det kan også betyde at omvende sig til Gud (se fx Jes 10,21, hvor det er Jakobs rest, der vender om til den vœeldige Gud). Set i krigssammenhœengen kan det betyde at vende tilbage fra slagmarken, mens det i lyset af spørgsmålet om tillid til Jahve kan betyde, at der er en rest, 
som vender sig til Gud. Denne dobbelttydighed skal ikke uden videre fjernes, men må ses som mulige fortolkninger alt efter den situation, ordene lceses i.

Også udtrykket en rest kan forstås på to måder alt efter udgangspunktet. Hvis udgangspunktet er angsten for at blive besejret i krigen eller angsten for, at alle afviser Jahve, så er det et positivt udtryk. Der er dog stadig en rest, som vender tilbage/vender om. Men det kan også opfattes som udtryk for, at kun en lille del er tilbage, Jes 6,12-13. Også her galder det, at begge laesninger er mulige, og tolkningen vil afhcenge af konteksten.

Det fremgår ikke af teksten, hvem denne rest er. Det kan vare en rest af folket, eller det kan vœre Jesajadisciplene eller Davidsdynastiet. I den følgende episode, v. 10-17, er det under alle omstœndigheder Davidsdynastiets fortscettelse, der er emnet. Også her gœelder det, at den sammenhceng teksten lœeses i, er medbestemmende for tolkningen.

Den følgende oplysning om, hvor de skal mødes, er betydningsfuld. Akaz og profeten skal fx ikke mødes i templet. Her opfører Akaz’ søn Hizkija sig helt modsat, idet han går op i templet og beder til Jahve, da assyrerne belejrer Jerusalem (jf. skildringen af den fromme Hizkija i Jes 37). Akaz er derimod gået ud til Øvredammens vandledning, dér hvor man henter vand til at vaske sit tøj. Kongen tcenker strategisk. I tilfœlde af en belejring er vandforsyningen afgørende for, hvor lcenge man kan overleve i byen. Jerusalems vandforsyning er sårbar, idet byen ligger på et højdedrag, mens vandforsyningen primœrt består af en kilde nede i Kedrons dal, Gihonkilden.

\section{Faktaboks: Jerusalems vandforsyning}

Muligheden for at skaffe vand er en vœsentlig forudscetning for, at der kan opstå en større bebyggelse. Vand er i Den Ncere Orient en mangelvare i store dele af året. Til brug for vandforsyningen kunne man dels udhugge cisterner, der kunne opsamle regnvandet, dels udnytte eksisterende kilder. Adgangen til de naturlige kilder er dog ofte et problem i forbindelse med en belejring. Hvis en by skal vare nem at forsvare mod fjender, skal den helst ligge højt, men kilder udspringer normalt på lavtliggende steder. Jerusalem ligger netop på et højdedrag og er som sådan nem at forsvare mod vest, syd og øst; men den eneste naturlige kilde, Gihonkilden, ligger nede i Kedrondalen på østsiden af byen. Man har derfor allerede i førisraelitisk tid udgravet en lodret skakt ned til dalens niveau og gennem en vandret kanal skabt sig adgang til kilden. Det er denne kanal, der kaldes Siloa, og som Jesaja bruger som billede på Jahve i Jes 8,6. Under belejringer var det muligt for fjenderne at hindre adgangen til Gihonkilden og dermed standse vandforsyningen. For at forbedre systemet anlagde Hizkija en underjordisk tunnel på ca. 600 m, der førte vand fra Gihonkilden ind bag forsvarsvœrkerne, 2 Kong 20,20, til Siloadammen, som ligger nordvest for Nedredammen. De to damme var for- 
bundet gennem en kanal. I forbindelse med Siloatunnelen var der udhugget en indskrift, der fortcller, hvordan to arbejdshold begyndte i hver sin ende og mødtes på midten. Tunnelen blev formentlig anlagt før Sankeribs belejring af Jerusalem i 701 f.Kr.

\section{$4-6$}

Hvad Jesaja skal forkynde meddeles af Jahve i form af to orakler, hvoraf det første, v. 4-6, er formet i prosa og skal trøste kongen. Med hele to imperativer og to verber med foranstillet negation opfordres kong Akaz til ikke at foretage sig yderligere i situationen, men bevare modet (se i øvrigt SI 20,8 og 33,17 til afvisningen af militcr magt). Udtrykket "Frygt ikke" er det prcegnante udtryk for et frelsesorakel og har derfor som formål at skabe tillid til Jahve i en kritisk situation. Der lœgges stor vœgt på, at det er en frygtsom konge, profeten henvender sig til. Den direkte opfordring til ikke at frygte underbygges med en spottende sammenligning mellem de fremmede konger og de to stumper trœe, som der endda er gået ild i. Billedet skal vise, at selv om konger kan sammenlignes med store stcrke trœer, så har disse trœer mistet al deres kraft. Der er stort set ikke noget tilbage af dem, ikke så meget som en stub, der kan spire igen. Når ilden har haerget, så er der ikke grund til at forvente nogen stor fremtid for trœerne (jf. billedet af en skovbrand i Jes 9,17-18 og 10,16-19). Selv om deres vrede er brœndende, er den nok ikke så truende, når den kommer fra nogle nœsten udslukte trœstykker.

Årsagen til frygten angives derpå i v. 5-6: Aram ncevnes først og er historisk set nok også initiativtageren til oprøret mod assyrerkongen. Efraim, Nordriget, og dets konge, Remaljas søn, er gået med på planerne, som går ud på at tage magten fra Judas konge, Akaz, og anscette en konge, der vil støtte dem i oprøret. Ud over dette ved vi intet om, hvem Tab'als søn var. At v. 6 citerer, hvad Arams konge har sagt skal give beretningen autenticitet. Det er ikke planer, som andre tillagger ham; han har selv formuleret dem (se tilsvarende i Jes 10,8-11.13-14, hvor assyrerkongens ord gengives som bevis for hans hovmod).

\section{7-9}

Efter beretningen følger et stykke poesi, som indholdsmcessigt er et betinget frelsesorakel. Ofte bruges netop den poetiske udtryksform til at udtrykke et højdepunkt i en fortcelling, fx Gen 3,14-19 og 4,23-24. I forlcengelse af de trøstende ord om, at der ikke er grund til frygt, følger et frelsesorakel, men vel at mœrke med en betingelse. Det er Jahve selv, her omtalt som herre, ארני, der taler (til bru- 
gen af sendebudsformlen, כה אמר יהוה, se nœrmere s. 36-37) og indledningsvis afviser muligheden af, at de to fjendtlige konger skal få held med deres forehavende. I to parallelle udsagn, der forstcrker hinanden, lover Jahve, at det ikke skal lykkes og ske.

Løftet begrundes i de følgende to vers, v. 8-9. I samme rœkkefølge som ovenfor ncevnes først landet Aram, dets hovedstad, ראש Damaskus samt dets konge, ראש, Resin. Ved at bruge den samme glose om hovedstaden og dens leder knytter Jesaja de to nœrt sammen, og modstanderen bliver betegnet som en magtfaktor. Den anden modstander beskrives tilsvarende: Efraim, dvs. Nordriget, har Samaria som hovedstad og Remaljas søn som sin konge. Mens Nordrigets konge i v. 1 blev kaldt ved navn, Peka, og derudover bestemt som søn af Remalja, bruges kun hans fars navn i v. 5 og v. 9. Dette kan tolkes som en lidt distancerende måde at omtale en person på (se fx 1 Sam 20,27-30, hvor Saul, der efterstrœber David, omtaler ham som Isajs søn, mens hans trofaste ven Jonatan kalder ham David).

Omtalen af de to lande og deres hovedstaeder og konger er helt parallel. Men parallelismen brydes af et indskud, der forudsiger, at om 65 år er Efraim knust. De 65 år er ikke noget rundt tal med symbolsk betydning. Det må derfor have givet mening på et tidspunkt, at hvis man regnede tilbage til den syrisk-efraimitiske krig (734-32 f.Kr.), så var der netop gået 65 år, og nu var der indtruffet en alvorlig begivenhed på Nordrigets område. Det kan ikke vœre assyrernes erobring af Samaria, der tœenkes på, da det skete kort efter, nemlig i 722 f.Kr. Men da der ikke findes kilder, der kan uddybe, hvad der er tcenkt på, må vi lade det stå åbent, hvad der prccis er sket på det tidspunkt. Men det er vigtigt at bemarke, at Jesajas forkyndelse er blevet ført videre og kommenteret undervejs, når man mente at se en af hans profetier opfyldt.

At en redaktor på den måde har udfyldt "huller" i teksten er et velkendt fcenomen inden for Det Gamle Testamente (se også Jes 8,6-7). Profetorakler er blevet betragtet som aktuelle ud over den tid, de er blevet fremsat i, og har derfor givet anledning til fortolkende tilføjelser. Selve den redaktionelle proces, der har ført til den foreliggende Jesajabog, har bl.a. bestået i at placere orakler, som kunne fungere som uddybninger eller konsekvenser af andre orakler. Placeringen af veråbet i Jes 1,4-9 straks efter en anklagetale er et eksempel herpå. Gennem denne placering har redaktorerne givet deres svar på, hvordan det måtte gå det folk, der havde brudt med deres Gud. Veråbet får dermed som funktion at vœere den dom, der må fœeldes i konsekvens af anklagerne. Mens profeten oprindelig har ladet det stå åbent og dermed overladt til tilhørerne selv at drage en konklusion af anklagerne, påtager redaktionen sig den opgave at prccisere udfaldet. 
Jes 7,8-9 er omvendt et eksempel på, at det overlades til tilhørerne selv at drage konsekvensen af oraklet. De to parallelle udsagn om de fjendtlige konger krcver en fortscettelse. For hvilken konklusion skal tilhørerne drage af beskrivelsen af Aram og Efraim? Redaktionen har ikke givet noget svar, men har overladt det til laeserne selv at drage konklusionen. Da hele den politiske situation, som er baggrunden for Jes 7, implicerer tre lande, må parallelstrukturen skabe forventning om, at vi også skal inddrage den tredje part i konflikten, nemlig Juda. Hvad tilhørerne selv skulle taenke sig til, er derfor et udsagn, der må lyde således: Judas hoved er Jerusalem, og Jerusalems hoved er ...? Her er der så to muligheder. Skal parallelismen vare helt ens, må det sidste ord vaere Akaz. Han er den tredje af de konger, den syrisk-efraimitiske krig omfatter. I så fald vil profeten trøste kongen med, at han ikke skal glemme, hvem han selv er. Han er konge i Guds udvalgte by, Jerusalem. Det er til Jerusalems konge, intronisationsordene har lydt: "Du er min søn, jeg har født dig i dag.", SI 2,7. Hvad er så kongen af Aram set i det perspektiv? Eller Efraims konge, som jo ikke engang er af Davids slaegt?

Men der er også en anden mulighed. Sctningen kunne slutte med ordet Jahve i stedet. For hvem er den egentlige konge over Jerusalem og Juda, om ikke Jahve selv. Jesaja har jo netop set Jahve i kongeskikkelse siddende på sin trone, fortcelles det i Jes 6,1. I så fald er det modsctningen mellem den himmelske konge og de to jordiske konger, der skal indgyde Akaz tillid til, at de to konger ikke skal få held til at gennemføre deres planer mod ham. Begge muligheder står åbne, og det bedste er nok ikke at lade den ene udelukke den anden, for begge dele er sandt ud fra den jesajanske teologi.

Oraklet slutter med en formaning, der fungerer som en betingelse for frelsestilsagnet. Med et markant ordspil scettes der fokus på verbet אמן. Først anvendes det i hifil i betydningen at holde fast. Derpå anvendes samme verbum i nifal i betydningen at blive holdt fast (jf. brugen af glosen på dansk som afslutningsformel: Amen!). Verbet står uden objekt, men som objekt må underforstås Jahve. Derfor kan verbet אמן også få nuancen stole på eller tro på. Stoler de ikke på Jahve, så vil han heller ikke holde fast i dem.

Tilbage til indholdsfortegnelsen 


\section{Jes 7,10-17}

\section{Tekstkritik}

$11 \mathrm{a}$

LXX gengiver שארל שאלה, der er imperativ af verbet om det var ordet for dødsriget, sheol. Dette krœver blot en œndring af vokalisationen. At der er tale om dødsriget ville passe bedre i konteksten, da dødsriget er modsctningen til det høje. Netop modscetningen er understreget af de to andre gloser: העמק (dybt nede) og הגבה (højt oppe). Imperativen "bed!" bryder derimod sammenhœengen i verset. DO 1992 følger med god grund rettelsesforslaget.

\section{Karakteristik}

Om den følgende episode siges ikke, hvor tœt den ligger på mødet ved vandledningen, og under hvilke ydre omstcendigheder profeten taler til kongen. Men temamœssigt er de tœet knyttet til hinanden, da begge bygger på centrale forestillinger fra Zionteologien, og placeringen viser, at den skal lœses som et nyt eksempel på, hvordan kong Akaz under den syrisk-efraimitiske krig får et frelsestilsagn gennem profeten Jesaja. Tilbuddet om et tegn skal vise kongen, at Jahve gerne vil give ham noget, der kan styrke hans tillid til, at Jahve vil hjœelpe ham. Kongens modvilje mod at tage imod et tegn tolkes af profeten som modvilje mod Jahve selv og antyder dermed det forhcrdelsestema, der ligger bag de tre episoder. At profeten til trods for kongens modvilje fremscetter et positivt orakel har til formål at understrege Jahves frelsesvilje. Oraklet er et løfte om, at der skal fødes en dreng, som skal hedde Immanuel. Lœst i konteksten er det mest sandsynligt, at det er en kongesøn, der tcenkes på. Løftet skal derfor forstås ud fra andre eksempler på, at Jahve tilsiger Davidsdynastiet et vedvarende kongedømme, Davidspagten, 2 Sam 7,12; SI 89,20-38; 132,1 1-12. Det er samme positive tone, der karakteriserer beskrivelsen af den tid, der skal følge efter kongesønnens fødsel: Den nye kongesøn skal spise en scerlig føde, folkets fjender skal blive besejret, og storhedstiden fra før rigets deling skal vende tilbage. Selv om oraklet angår den nœre fremtid, er det senere blevet tolket om en Messias, der skal fødes ude i fremtiden. Udeblivelsen af den ideelle konge samt ophøret af kongedømmet i forbindelse med det babylonske eksil har ført til, at opfyldelsen af oraklet er blevet lagt løengere ud i fremtiden, så det i kristendommen først ses opfyldt med Jesu fødsel. 


\section{Struktur}

10-12: Jahves tilbud om et tegn og kongens afvisning.

13-14: Frelsesorakel om en kommende kongesøn, Immanuel.

15-17: Beskrivelse af den lykkelige fremtid under Immanuel.

\section{Fortolkning}

10-12

At der er tale om et orakel fra Jahve understreges i v. 10, hvor Jahve selv er subjektet. I v. 3 sendes profeten med et budskab til kongen, i v. 7 prceciseres det, at profeten taler på Jahves vegne, men her identificeres den talende som Jahve selv. Der lœegges på den måde stadig større vœegt bag ordene, og netop derfor vil en afvisning af Jahves henvendelse vœre så meget desto mere forkastelig. At tegnet skal komme fra Jahve din Gud giver tegnet trovœrdighed. Et tegn er normalt i stand til at overvinde mistillid. Da Moses vaegrede sig ved at påtage sig den opgave at føre folket ud af Egypten, lovede Gud ham et tegn, Ex 3,12. Om Gideon fortcelles det, at han selv beder om et tegn og får det, da han kaldes til dommer, Dom 6,15-24. At der ikke er sat grœenser for, hvilken type tegn, Jahve vil give, fremgår af formuleringen העמק שאלה הגבה למעלה. Ved at angive yderpunkterne i universet, markerer man totalitet. Dødsriget, Sheol (teksten rettes, se ovenfor), var i datidens univers placeret nederst, fx Deut 32,22 og SI 86,13, og med det høje tcenkes der på himlen øverst oppe.

Akaz' reaktion er en afvisning. Begrundelsen, at han ikke vil udœeske Jahve, kan underbygges med et andet sted i Det Gamle Testamente, Deut 6,16, hvor der udtrykkeligt hedder: "I må ikke udœeske Herren jeres Gud, sådan som I gjorde ved Massa." De steder, hvor der fortclles om, at mennesker har udaesket Gud, er holdningen da også klart negativ, Ex 17,2.7; SI 78,18.41.56; 106,14. At udœeske, נסה, betyder at scette på en prøve for at tvinge en anden til at bevise noget. I Det Gamle Testamente er det i øvrigt ikke ualmindeligt, at Gud udscetter mennesker for sådanne prøvelser for at se, om de er loyale, fx Gen 22,1; Deut 8,2.16. Men når mennesker gør det samme, vender de op og ned på forholdet mellem Gud og menneske. Så selv om Akaz må siges at kunne begrunde sin afvisning teologisk, viser reaktionen fra profetens side, at han opfatter Akaz som et menneske, der ikke har den nødvendige tillid til Gud. Akaz formulerer sig med to parallelle ncegtelser og understreger dermed sin holdning. Han forhcerder sig og er på den måde med til at virkeliggøre Jesajas opgave, Jes 6,9-10. 


\section{3-14}

Profeten, der må vaere subjektet for verbet אמר, at sige, i v. 13, reagerer med en alvorlig formaning, indledt med en opfordring til at lytte (if. Jes 6,9 skal de ganske vist høre, men ikke fatte!). Kongen omtales nu som בית דוד, Davids Hus, hvilket skaber associationer til Davidspagten. Jahve har lovet, at han vil bygge et hus for David, dvs. skabe en kongeslaegt, 2 Sam 7,1 1-12. Af salmer som SI 89,20-38 fremgår det, at Davidsdynastiet er blevet betragtet som et evigt dynasti, som altid vil vœre under Jahves beskyttelse. At en konge af Davids sløegt ikke tør stole på Jahve strider derfor mod al forventning og fornuft. Kongens opførsel er til gene ikke blot for mennesker, men også for Gud. Profetens holdning fremgår i øvrigt af, at han ikke blot siger Gud, men min Gud, אלהי. Brugen af suffiks for første person sctter et skel mellem Akaz på den ene side og Jesaja og Gud selv på den anden side.

På den baggrund forventer man som lceser ikke, at der skulle komme et positivt tegn til den vantro konge. Ikke desto mindre følger der, direkte knyttet til det foregående gennem partiklen לכן, der som oftest indleder en trussel eller et domsorakel, et positivt orakel fra Herren. Oraklet i v. 14 er rettet til "jer", dvs. 2. person flertal. Dette kan dels betyde, at oraklet gaelder hele folket dels markere, at Akaz ikke lcengere er den, profeten først og fremmest henvender sig til. Tegnet består af noget, der skal ske i denne verden, altså ikke i universets yderkanter, men midt i kongens hverdag. Den unge kvinde, som skal føde en søn, kaldes på hebraisk העלמה. Ordet angiver en ung kvinde, som er gammel nok til at have en mand. Der findes et scrligt ord på hebraisk for en jomfru, בתולה (se fx Gen 24,16, der omtaler Rebekka som en jomfru, der aldrig havde varet sammen med en mand), men det bruges ikke i Jes 7,14. Til gengceld er det glosen for jomfru, der bruges i den grceske overscettelse, LXX, af dette sted. Det samme er tilfœldet i Det Nye Testamente, hvor oraklet citeres som en forudsigelse af, at jomfru Maria skal føde Jesus, Matt 1,23 (se også Luk 1,27.31). Hvor oraklet i Det Gamle Testamente henviser til en almindelig fødsel, bruges det i Det Nye Testamente som argument for en uscedvanlig fødsel, nemlig en jomfrufødsel.

At fødslen skal finde sted inden for den nœrmeste fremtid fremgår af de grammatiske former, der anvendes. Den unge kvinde er allerede gravid, hvilket fremgår af adjektivet הרה Og at hun derfor snart skal føde, viser desuden brugen af prcesens participium af verbet føde, יולדת. Der er således tale om et tegn, som kongen snart vil kunne se og derigennem få styrket sin svigtende tillid til Jahve. Barnet, der tales om, må derfor vœre en kongesøn, da Akaz' angst må gclde dynastiets overlevelse, nu hvor de to fjendtlige konger truer med at erobre Jerusalem og tage magten dér. 
At det drejer sig om en kongesøn kan yderligere underbygges med en henvisning til, at der findes en ugaritisk tekst, der lyder: "Se, den unge kvinde skal føde en søn". Det er en rituel tekst, som har vœret anvendt ved bryllupper, evt. kongens og dronningens, som en velsignelse. Hvis det er en sådan bryllupsvelsignelse, der genbruges i Jes 7,14, burde den også medvirke til at give Akaz tillid til Jahve og til fremtiden (se ncermere i Hans Gottlieb 1986, 96). I øvrigt minder udsagnet om det tilsagn, englen gav Hagar, da hun var på flugt for Sara, Gen 16,1 1 (se også Dom 13,3.5), og som netop skulle indgyde Hagar tillid til fremtiden.

Ligesom Hagar fik at vide, hvad barnet, Ismael, skulle hedde, indeholder også forjœttelsen til Akaz det navn, barnet skal have. Og ganske som i Jes 7,3 er navnet en forudsigelse (nomen est omen). Kongesønnen skal kaldes Immanuel, עמנו אל. At "Gud er med os" skal gennem sønnen blive åbenbart for enhver. Han skal gå rundt som et tegn fra Jahve på, at han vil beskytte Davidsslœgten og dermed sit eget folk.

\section{5-17}

De følgende vers giver en beskrivelse af den lykkelige fremtid under Immanuel. Forskerne har ganske vist diskuteret, om den omtalte føde, tykmœlk og honning, skal tolkes som tegn på smalkost, eller der er tale om en sœrlig paradisisk føde. De, der mener, at det er udtryk for en fattig tilvœrelse peger på, at det er nomadekost. Mere overbevisende er dog henvisningerne til den scrlige kost, der kendetegner den lykkelige fremtid. I Joel 4,18 beskrives "den dag" netop som en dag, hvor "bjergene skal dryppe af most og højene flyde med mclk" (se også Am 9,13), mens Deut 32,13-14 beskriver, hvordan Jahve førte folket i ørkenen og mœttede dem med "honning fra bjerget, med olie fra flinteklippen, med tykmœlk fra køer og får...". Under vandringen fra Egypten til Det Forjœttede Land var folket under Guds sœrlige beskyttelse og fik derfor også en sœrlig kost. Jahve vil tage sig sœrligt af den unge kongesøn i de første år, indtil han er stor nok til at vœlge mellem godt og ondt. Det er ikke nogen prœcis tidsangivelse, men giver dog et klart indtryk af, at det ikke drejer sig om en fjern fremtid. Tidsangivelsen er ikke prcecis, og måske skal vi tilsvarende fastholde, at omtalen af føden er tvetydig, ligesom fx navnet på sønnen i Jes 7,3 er tvetydigt.

Parallelt med oplysningerne om den scrlige føde følger løftet om, at de to fjendtlige konger skal besejres, dvs. Aram og Efraim. Også dette skal ske før drengen er blevet i stand til at valge mellem godt og ondt. Ud over at udtrykket angiver en tidshorisont, kan man også se det som et udtryk for, at nok skal der fødes en ny kongesøn, som man kan knytte mange positive forventninger til, men 
sejren over fjenderne ligger ikke i hans barnehånd, underforstået: Det er Jahve selv der besejrer folkets fjender. Dette understøttes af at subjektet i v. 17 er Jahve. Det er ham, der styrer historiens gang, og sender fremtiden over dem.

At det i v. 17 er prœpositionen על , der anvendes, giver umiddelbart indtryk af, at der kommer noget negativt. Ganske som det var tilfœeldet med brugen af לכן i v. 14. Men endnu engang er forkyndelsen mere positiv, end indledningen kunne tyde på. For fremtiden skal ligne en tidligere fase i folkets historie, nemlig tiden før Efraim, dvs. Nordriget, rev sig løs fra Juda, Sydriget. Der tcenkes her på beretningen om, hvordan Davids og Salomos storrige blev delt efter Salomos død. De nordlige stammer valgte Jeroboam, en efraimit, der tidligere havde gjort oprør mod Salomo, som deres konge. Juda stamme fastholdt derimod Rehabeam som konge. Han var søn af Salomo og dermed af Davids slœgt, 1 Kong 11-12.

Tiden før rigets deling, og isœr tiden under David, er i gammeltestamentlig tradition opfattet som en storhedstid, selv om der ikke lœegges skjul på, at Salomo selv var medskyldig i, at riget blev delt. Når profetien derfor taler om dage, som man ikke har kendt siden rigets deling, er der tale om en lykkelig tid. At de to riger igen skulle samles til ét hører med til fremtidshåbet, således som det også kommer til udtryk i Jes 11,13, som uddyber beskrivelsen af det kommende fredsrige.

Versets sidste ord, את מלך אשור, kan dårligt lœses som andet end en trussel. Den lykkelige fremtid kommer ikke omkostningsfrit (jf. den negative tolkning af navnet שאר ישוב, kun en rest vender tilbage - fra slagmarken eller til Jahve, Jes 7,3). Assyrerkongen nœvnes underligt efterhœngt, hvilket kan skyldes, at der er tale om en senere tilføjelse. Men uanset om det er en senere henvisning til de politiske begivenheder, der fulgte efter den syrisk-efraimitiske krig, så passer det godt ind i det jesajanske budskab, sådan som det fremstilles i de følgende kapitler.

I Jes 8,7 henvises der ligeledes kort til assyrerkongens indflydelse, mens Jes 10,5-32 er én lang fortolkning af assyrerkongens rolle som redskab for Jahves planer. Fredsriget, som udfoldes i kap. 11, forudsctter, at assyrerkongen først udfører Jahves straf over det ulydige folk. Derefter, når der kun er en rest tilbage, eller som det hedder i Jes 1,8, "en hytte i vingården", er der mulighed for en lykkelig fremtid.

Jes 7,10-17 giver god mening allerede i forbindelse med den syrisk-efraimitiske krig, hvor assyrerkongen hele tiden var stormagten i baggrunden, som ikke blot Aram og Efraim måtte forholde sig til, men også Juda (jf. 2 Kong 16,7, hvor Akaz selv sender bud til assyrerkongen og beder ham: "Kom og frels mig fra Arams og Israels konger."). Men forkyndelsen har vœret mindst lige så overbe- 
visende i 701 f.Kr., hvor Sankerib måtte opgive belejringen af Jerusalem til trods for de store erobringer i omegnen. Assyrerkongen var ikke til at komme uden om, men det var i sidste ende deres egen Gud Jahve, der styrede assyrerkongens hånd. Og det skal nok ikke alene ses som en trøst, når det er den hellige Gud, der er tale om i Jesajabogen. Derfor kan man også i navnet Immanuel høre en påmindelse om, at Jahve er ncervœrende og derfor heller ikke overser, hvad en konge som Akaz foretager sig. Også navnet Immanuel er dermed dobbelttydigt.

Tilbage til indholdsfortegnelsen

\section{Jes 7,18-25}

\section{Tekstkritik}

Der er ingen grund til at rette i teksten.

\section{Karakteristik}

Afsnittet består af fire enkeltorakler, v. 18-19; v. 20; v. 21-22; v. 23-25, der har det til fœlles, at de alle indledes med formuleringen והיה ביום ההוא, det skal ske på den dag (i v. 20 dog uden והיה). Der er tale om en redaktionel placering af forskellige orakler med det formål at supplere fremtidsskildringen i Jes 7,16-17. Henvisningen til den dag skal derfor forstås ud fra Jes 7,17 og ikke om en eskatologisk begivenhed. Oraklerne er meget billedrige, men netop den billedrige stil kan give vanskeligheder, når oraklerne skal tolkes. Det kan derfor diskuteres, om v. 21-22 er positivt, som nogle forskere mener, eller negativt. Hovedindtrykket er dog, at det er en mørk fremtid, folket har i vente, når Jahve hidkalder deres fjender. At det først og fremmest er negative orakler, der følger efter de to positive tilsagn til kong Akaz, må ses som udtryk for redaktorernes vurdering af Akaz som en konge, der forhcerder sig over for Jahve og dermed nedkalder Jahves straf. Mens udsigterne ifølge Jes 7,10-17 er positive, viser de følgende orakler primœrt et negativt billede af fremtiden: Konsekvensen af Akaz' forhœrdelse er Jahves straf..

\section{Struktur}

18-19 På den dag skal Jahve tilkalde Egypten og Assyrien, der kommer som fluer og bier.

20 På den dag skal Jahve bruge assyrerkongen som barberkniv.

21-22 På den dag skal tykmœlk og honning vœere hverdagskost. 
23-25 På den dag skal tjørn og tidsel overtage vinmarkerne og kvœget trampe landet ned.

\section{Fortolkning}

18-19

Det første orakel beskriver Jahve som en, der kan tilkalde de to hovedfjender, Egypten og Assyrien, ved at fløjte ad dem (jf. Jes 5,26), som om de var fluer eller bier. I datiden forestillede man sig, at det var muligt at tilkalde vilde bisvœrme ved hjœlp af lyd. Det afgørende i billedet er dog, at det er Jahve, der kan bruge de fremmede folk som sit redskab. Forskerne har forsøgt at datere oraklet ud fra omtalen af både Egypten og Assyrien; men i perioden omkring den syrisk-efraimitiske krig var Egypten ikke nogen trussel mod Juda. I stedet for at forsøge at finde en bestemt historisk begivenhed, som dette vers kunne afspejle, skal man nok tolke Egypten og Assyrien som reprœsentanter for Judas og Israels store fjender (jf. at begge omtales såvel i Hos 9,3; Hos 11,5; Hos 12,2 som i Jer 2,36).

At det har vœeret vigtigt at understrege selve truslen fremgår også af beskrivelsen af, hvordan fjenderne kommer og slår sig ned over alt. At der specifikt tales om dalslugter, klippespalter, tjørnekrat og vandingssteder har svaret til, hvad man har varet vant til, når insekter oversvømmede landet.

\section{0}

Også det andet orakel taler i billedsprog om en trussel udefra. Igen er Jahve den, der bruger den fremmede fjende til sit eget formål. Fjenden kommer fra den anden side af floden, dvs. øst for Eufrat (jf. Jos 24,2-3.14-15) og bestemmes ncermere som assyrerkongen. Som det også fremgår af DO 1992, hvor udtrykket "med assyrerkongen" er placeret mellem tankestreger, er der formentlig tale om en tilføjelse, der skal gøre det helt klart, hvem fjenden er. I så fald viser tilføjelsen, hvordan man på et senere tidspunkt har tolket oraklet. Assyrerkongen er skildret i billedet af en barberkniv, som bruges til at fjerne håret både på hovedet og på underkroppen (på hebraisk kan רגלים, fødder, bruges som eufemisme for kønsdelene, jf. Jes 6,2) samt selve skœgget. En sådan behandling af en mand udtrykker den største foragt og kan kun opfattes som en œrekrœenkende handling. En lignende behandling er beskrevet i 2 Sam 10,4, hvor ammonitterkongen mishandler Davids sendebud ved at rage deres skœg af og skcere den nederste del af deres tøj af, så bagdelen blottes. Det siges ikke her i v. 20, hvem denne behandling skal gå ud over; men ud fra konteksten er der ingen tvivl om, at 
det gœider Jahves eget folk. De skal opleve, at assyrerkongen kommer og berøver dem deres œre. Hvordan det skal ske siges ikke, billedet er åbent for senere fortolkning.

\section{$21-22$}

Med de følgende to vers rejser der sig et fortolkningsspørgsmål. Er fremtiden her opfattet negativt eller positivt? Oraklet giver en situationsrapport, der viser tilstanden i landet. Her er ikke tale om hungersnød, alle får noget at spise, for der skal vœere både kvier og får. Men det kan diskuteres om en kvie og to får skal opfattes som udtryk for det minimum, man kan overleve på, når man supplerer med honning, eller om tykmcelk og honning skal opfattes som tegn på en scrlig paradisisk tilstand. For det første taler konteksten, som er negativ, samt at der direkte tales om dem, der er levnet i landet. Der er altså gået en katastrofe forud. Og set i sammenligning med den rakke af forskellige madvarer, som Egypten berømmes for i Num 1 1,5 til forskel for mannaen, kan kosten betragtes som noget ensformig. Omvendt kan man pege på, at malk, חלב - som kan bruges til tykmalk חמאה - og honning, רבש, i traditionerne om indvandringen i Det Forjœttede Land bruges som betegnelse for landets overflod. De skal netop overtage et land, der flyder med mcelk og honning (jf. fx udtrykket $\mathrm{i}$ Ex 3,8: ארץ זבת חלב ודבש;; se også Deut 6,3; Jos 5,6; Jer 11,5; Ez 20,6). Endelig nœevnes det i forbindelse med barnet Immanuel i v. 15, at han skal opfostres på netop tykmaelk og honning. Også dette tyder på, at denne spise skal opfattes som noget positivt.

At redaktorerne har placeret et enkelt positivt orakel midt mellem de negative udsagn, kan også ses i forlœngelse af den resttanke, som findes i Jes 7. Katastrofen er uundgåelig, men en rest skal vende tilbage (fra krigen) eller vende om (til Jahve), sådan som navnet på Jesajas søn, שאר ישוב, Jes 7,3, forudsiger.

\section{3-25}

Det sidste af de fire orakler er klart negativt. Udgangspunktet er de steder, hvor der findes 1000 vinstokke. Jorden med vinstokkene har en vœerdi af 1000 sekel, ca. $15 \mathrm{~kg}$ sølv. Der er tale om en ganske høj vœerdi målt med datidens øjne. Og netop de gode vingårde skal blive overgroet af tjørn og tidsel. Formuleringen שמיר ושית, tjørn og tidsel, forekommer hyppigt i Jesajabogen som udtryk for, at det dyrkede land bliver en del af det kaos, som bl.a. kendetegner ørkenen (jf. Jes 5,6, hvor vingården, efter at ejeren har opgivet at tage sig af den, forfalder og gror til med tjørn og tidsel). Overladt til sig selv kan vinstokkene ikke klare sig. Af v. 24 fremgår det, at landet nu er helt dckket af tjørn og tidsel. 
Omtalen af bue og pil kan forstås sådan, at kun jcegere vover sig derud, men det kan også markere, at man ikke tør gå ubevœbnet af angst for vilde dyr. Er det sidste tilfœeldet, løegger det op til omtalen af frygten for tjørn og tidsel i det følgende vers. Ingen vover at gå ud og forsøge at genopdyrke bjergskråningerne. Tjørn og tidsel har fået overherredømmet. Kun kvœget begiver sig derud, men også de bidrager til ødelœggelsen af landet.

Med de fire orakler peges der på konsekvenserne af kong Akaz' afvisning af det frelsesbudskab, Jesaja kommer med fra Jahve. Men herefter giver redaktorerne i Jes 8, 1-4 endnu et eksempel på Jahves gode vilje over for sit eget folk, nemlig gennem beretningen om endnu et barn, der barer et scerligt navn.

Tilbage til indholdsfortegnelsen

\section{Jes 8,1-4}

\section{Tekstkritik}

Der er ingen grund til at rette i teksten.

\section{Karakteristik}

Afsnittet indgår i den tredje episode i Jesajas Denkschrift og indeholder som de to øvrige navnet på en søn. Også her gcelder det, at navnet indeholder en forudsigelse: Nomen est omen. Mens de to første episoder, Jes 7,3-9 og 7,10-17, er fortalt i tredje person, er Jes 8,1-18 holdt i første person svarende til Jes 6. Der er således tale om en cirkelstruktur, hvor der begyndes og afsluttes med profeten som fortcelleren. Dette taler for, at Jes 6,1-8,18 på et tidspunkt har eksisteret som en selvstcendig helhed (jf. s. 99-101).

Afsnittet falder i to dele, hvoraf den første del, v. 1-2, består af Jahves befaling til profeten om at skrive Le-Maher-Shalal Hash-Baz, til hastigt bytte, hurtigt rov, på en stor tavle og indkalde vidner. Nedskrivningen af ordene er en tegnhandling, hvis betydning skal blive klar, når den begivenhed, som ordene hentyder til, indfinder sig. Til den tid skal vidnerne bekrcfte, at Jahves plan allerede forelå forud for begivenhederne. Anden del af afsnittet, v. 3-4, er opfyldelsen af tegnhandlingen. Profetens hustru bliver gravid og føder en søn, som Jahve befaler Jesaja at kalde Maher-Shalal Hash-Baz. Jahve udløgger navnet, så det bliver klart, at det hastige bytte og hurtige rov er en henvisning til assyrerkongens sejr over Judas to fjender under den syrisk-efraimitiske krig, Syrien med ho- 
vedstaden Damaskus, og Nordriget med hovedstaden Samaria. Hvor navnet løest uden denne udlœgning står som et truende udsagn, som meget vel kunne få samtiden til at frygte Jahves planer, viser udlœegningen, at også det tredje navn er udtryk for Jahves vilje til at redde sit eget folk.

\section{Struktur}

1-2 Tegnhandling: Jahve befaler profeten at skrive nogle ord på en tavle i vidners ncervcer.

3-4 Opfyldelsen og udløgningen af tegnhandlingen: Profetens søn skal bœre navnet, som stod på tavlen som tegn på Jahves redning af sit eget folk.

\section{Fortolkning}

$1-2$

Tegnhandlingen indledes på Jahves initiativ med en befaling til profeten. Tilsvarende befalinger til at foretage en tegnhandling findes flere steder i Ezekiels Bog. Befalingen indledes alle steder med et: קח לך, hvorefter objektet indføres og det dermed prœciseres, hvad det er for en genstand, profeten skal bruge til tegnhandlingen. I Ez 4,1 drejer det sig om en teglsten, som profeten skal tegne Jerusalem på, i Ez 4,9 skal profeten tage forskellige slags korn til at bage brød af, og i Ez 5,1 skal han tage et svœrd og rage hår og skœeg af med. Endelig er der i Ez 37,16, som indholdsmœssigt kommer tcettest på Jes 8,1, tale om at skrive noget på et stykke trœ. Mens de tre første handlinger skal fungere som tegn på Jahves straf, er Ez 37,16 indledningen til et frelsesorakel (se også Hos 1,2, hvor profeten skal tage en horkvinde til œgte som tegn på folkets frafald ).

I Jes 8,1 er objektet en tavle, גליון. Den skal vœre stor, så den kan vœre nem at få øje på, og ordene skal skrives med en løeselig skrift. Glosen חרט betegner en griffel, men må her angive selve skriften. At skriften skal vœre en menneskeskrift betyder, at den skal vare til at lœese for andre. Begge krav understreger, at det budskab, profeten skal formidle, skal vœre offentligt tilgœengeligt. Om tavlen skal stå ved templet, hvor mange kommer forbi, eller på et andet offentligt sted, siges der ikke noget om. En tilsvarende befaling ncevnes i Hab 2,2, hvor profeten bliver pålagt at skrive det syn, han får, "tydeligt på tavler, så det er let at lœse". Det syn, profeten får, gœlder nemlig et tidspunkt ude i fremtiden, men allerede nu skal nedskrivningen fungere som vidne.

På tavlen skal Jesaja skrive de fire ord: למהר שלל חש בז. Budskabet, til hastigt bytte, hurtigt rov, må umiddelbart opfattes som et ulykkesbudskab. Nogle skal blive overfaldet, og i hast skal fjenden bortføre sit bytte. Hvem fjenden er, og hvem de overfaldne er, fremgår ikke af indskriften på tavlen. 
Det må foreløbig stå åbent, hvilket ikke er så usœdvanligt, når det gœlder orakler. Et godt eksempel er det tvetydige orakel, som kong Krøsus ifølge Herodot fik, da han spurgte oraklet i Delfi, hvad der ville ske, hvis han gik i krig mod perserne. Da han fik det svar, at et stort rige ville gå til grunde, valgte han krigen. Hvad han ikke havde forestillet sig var, at det var hans eget storrige, der skulle ødelœgges!

At Jesajas budskab er vigtigt bliver yderligere understreget af de praecise angivelser af, hvem der skal vœere vidner til tegnhandlingen. For at noget kan vœre vidnefast, skal der mindst to vidner til, Deut 17,6; 19,15. Jahve sørger selv for vidnerne i dette tilfcelde, nemlig to trovcerdige mœend. Prcesten Urija er også omtalt i 2 Kong 16,10-11, hvor det er ham, kong Akaz overdrager ansvaret for at bygge et alter i Jerusalem magen til det, han har set i Damaskus under sit møde med assyrerkongen. Urija hører således til inderkredsen omkring kongen. Jeberekjas søn Zekarja er formentlig også ncer knyttet til kongehuset og identisk med den Zekarja, som var kong Hizkijas morfar, 2 Kong 18,2. Set ud fra hoffets synspunkt er der derfor tale om scerdeles trovardige vidner.

\section{$3-4$}

I de følgende vers fortcller profeten, at han gør sin kone, profetinden, gravid, og at hun føder ham en søn. Om betegnelsen profetinden, הנביאה, også indebcerer, at hun selv profeterer, fremgår ikke. Her er hendes rolle udelukkende at føde sønnen, ganske som den unge kvinde i Immanuelsprofetien, Jes 7,14. I første omgang forbindes indskriften ikke med profetens private forhold. Det sker først, da Jesaja får en ny befaling fra Jahve, nemlig at bruge ordene på tavlen som navn til sønnen. Sønnen skal dermed vœre bœrer af budskabet på tavlen. Og den tidlige nedskrivning af navnet, endnu før graviditet og fødsel, skal vise, at Jahves planer går forud for begivenhederne. Hvad der sker i den politiske verden er derfor ikke styret af menneskelige krcefter, men af Jahve selv.

Udlœgningen af barnets navn i v. 4 gør det klart, at set ud fra kong Akaz' synspunkt er budskabet endnu et frelsesbudskab. Ofrene for overfaldet er ikke Juda, men derimod de to fjender under den syrisk-efraimitiske krig, Syrien og Nordriget, og redskabet dertil er assyrerkongen. At der er tale om et hurtigt bytte fremgår også af den tidsangivelse, som verset indeholder. Assyrerkongen skal erobre de to hovedstader, Damaskus og Samaria, før drengen kan sige far og mor. Da far og mor formentlig er nogle af de første ord, et barn lœerer, er tidshorisonten meget kort, 1-2 år.

Oplysningen om Damaskus' og Samarias fald peger på begivenheder, der kan dateres til henholdsvis 732 f.Kr. og 722 f.Kr. I 732 f.Kr. erobrer assyrerkongen Tiglat Pileser III Damaskus og ind- 
lemmer Syrien i sit storrige. Samtidig overtager storkongen vigtige dele af Nordriget og fører befolkningen i eksil i Assyrien, 2 Kong 15,29 (se hertil Jes 8,23 med omtalen af de assyriske provinser $\mathrm{i}$ Nordriget). Nordriget er nu vasalstat under Assyrien. Først da det kommer til oprør mod assyrerne erobres Samaria, og Nordriget ophører med at eksistere i 722 f.Kr..

Horisonten for Jesajas Denkschrift er tydeligvis begivenhederne under den syrisk-efraimitiske krig og tiden frem til Nordrigets undergang. Det er en periode, hvor Juda er udsat for trusler fra de to stater lige nord for samt mere indirekte fra assyrerne. Netop i forholdet til de politiske begivenheder afslører Judas konge, hvordan han forholder sig til Jahve. De tre symbolske navne, Shearjashub, en rest vender om/tilbage; Immanuel, Gud med os, og Maher-Shalal Hash-Baz, hastigt bytte, hurtigt rov, viser Jahves vilje til at redde sit folk; men som det fremgår af Jes 7,9, så er betingelsen for at Jahve holder fast i dem, at de holder fast ved ham.

Tilbage til indholdsfortegnelsen

\section{Jes 8,5-8}

\section{Tekstkritik}

$6 a$

Der er formentlig opstået en forveksling af to forskellige s-lyde i 6a. MT skriver ומשוש, der betyder "og glœde", men ud fra konteksten må meningen vœre noget negativt. Dette kunne på hebraisk angives med udtrykket: ומסוס, der betyder "og modløshed", og som anvendes i Jes 10,18. Der er ingen tekstgrundlag for rettelsen, men DO 1992 vœlger at rette a.h.t. sammenhœengen i teksten. Hvis teksten ikke rettes, må omtalen af glœde forstås ironisk. Den glœde, de har følt, kommer til at koste dem dyrt.

\section{Karakteristik}

I direkte forlcengelse af det positive budskab følger nu et negativt budskab fra Jahve. Jahve anklager folket for at forkaste Siloas sagte rindende strømme, et billede på Jahve selv. Som straf sender Jahve assyrerkongen over dem, billedligt skildret som en vœldig flod, der skal stige helt op til halsen af dem. De to vandbilleder afspejler de to karakteristiske måder at opfatte vandet på i Det Gamle Testamente. Fra de to skabelsesberetninger kendes dels det ødeløggende vand, kaosvandet, som Jahve sœetter grœnser for i Gen 1,9-10, dels det livgivende vand, som er udgangspunktet for skabelsen i den anden skabelsesberetning, Gen 2,6 (jf. også SI 104,1-9.10-18). Vandmetaforikken under- 
streger Jahves herredømme over både det vand, der skaber frugtbarhed og velsignelse, og over det vand, der ødelœgger (jf. også beretningen om den store vandflod, Gen 6-9).

\section{Struktur}

5 Indledende angivelse af, at det er Jahve, der taler.

6-8 Anklage mod folket for frafald og trussel om assyrerkongens overfald på landet.

\section{Fortolkning}

5

Det nye afsnit er indledt med verbet ויסף, der angiver, at handlingen fortscetter. Endnu engang henvender Jahve sig.

\section{6-8}

Derpå følger selve oraklet. Det er formet som poesi og begynder med en anklage, som begrunder den efterfølgende trussel om straf. Verbet מאס betyder at forkaste og brugtes i Jes 5,24 om at forkaste Jahves lov. Nu er det ikke blot Jahves lov, men Jahve selv som den livgivende kilde, de afviser. Siloa er betegnelsen for en kanal, der fører vand fra Gihonkilden ind i byen. For at kunne skaffe sig vand under en eventuel belejring har man inden for bymuren hugget en skakt $13 \mathrm{~m}$ ned i klippen og derfra lavet en vandret kanal hen til kilden. På den måde kunne man, uden at udsctte sig for fjendeangreb, hente vand til de belejrede. Det er dette vandsystem, der senere hen, under kong Hizkija, renoveres og udbygges ved hjœelp af en $600 \mathrm{~m}$ lang tunnel, som fører ind til Siloadammen. I Jes 8,6 er det dog den førstncevnte kanal, der tcenkes på (se ncermere s. 114-115).

Billedet skal understrege folkets totale afhœngighed af Jahve. Ligesom indbyggerne i en belejret by ikke kan overleve, hvis vandforsyningen ødelœegges (jf. Jes 7,3), således kan folket ikke overleve uden forbindelsen til Jahve.

Anklagen begrundes med henvisningen til Resin og Remaljas søn, dvs. kongen af Damaskus og kongen af Nordriget. I DO 1992 er disse navne placeret mellem tankestreger, da de bryder sammenhcengen og formentlig er senere uddybende tilføjelser (jf. Jes 7,17). Følger man tekstrettelsen, er disse to konger, som under den syrisk-efraimitiske krig belejrer Jerusalem, Jes 7,1-9, årsagen til, at Juda mister modet og ikke lœengere har tillid til Jahve. 
Der er i denne sammenhœeng ikke sagt yderligere om grunden til folkets afvisning af Jahve. Men sammenligner man Jesajateksten med beretningen i 2 Kong 16 om kong Akaz' reaktion på de to fjenders forsøg på at tvinge ham med i en koalition mod assyrerkongen, så bliver det tydeligt, at baggrunden for Jes 8,6 må vœre den situation, hvor Akaz har valgt ikke at gå med i koalitionen, men tvœrtimod har sat sin lid til assyrerkongen og selv tilkaldt ham for at få hjœlp mod Resin og Remaljas søn Peka. Ifølge 2 Kong 16,7 beder Akaz Tiglat-Pileser om at komme og frelse ham fra "Arams og Israels konger, der har rejst sig mod mig!" Videre hedder det, at Akaz sender guld og sølv fra såvel templet som paladset til assyrerkongen som betaling for hjœlpen. Yderligere fortclles det, hvordan han bygger et alter magen til det i Damaskus for også på den måde at vise sin underkastelse under assyrerne (jf. den afslørende bemcrkning i 2 Kong 16,18: "Alt dette gjorde han på grund af assyrerkongen.").

Uanset hvor klog en handling, dette har vœret set ud fra en rent politisk vurdering (Nordriget gik under i 722 f.Kr., mens Juda først går under i 587 f.Kr.), så er dommen over en sådan handling entydigt negativ både hos deuteronomisterne og i Jesajabogen. At indgå aftaler med en jordisk storkonge er udtryk for mistillid til Jahve. I Jes 7,1-9 har profeten lovet kong Akaz, at Jahve vil hjœelpe ham; han skal blot stole på, at der stadig vil vare en rest tilbage. Der er derfor ingen grund til at tabe modet over "disse to rygende stykker trœ", Jes 7,3-4. I den følgende episode får han tilsagn om, at kongeslœgten skal bestå, Jes 7,10-17, og endelig har Jahve gennem navnet på profetens søn, Jes 8,1-4, offentligt tilkendegivet, at straffen skal ramme Syrien og Nordriget. Alligevel valger kong Akaz at kaste sig i armene på assyrerkongen og dermed fravcelge Jahve.

I den situation giver det god mening, at profeten forkynder Jahves straf over folket. Deres bekymring over jordiske fjenders magt er større end deres tillid til Jahve. Og dermed viser de, at den forhcerdelse, som profeten skal udvirke ifølge Jes 6,9-10, er en realitet. De er virkelig blevet forhcerdede, når de afviser et frelsesbudskab fra Jahve.

At netop assyrerkongen omtales i billedet af en stor flod, v. 7, hcenger godt sammen med de geografiske forhold. Assyrien er landet mellem floderne, Mesopotamien, og stammer dermed fra et område, hvor oversvømmelser er en aktuel trussel. Nu skal han selv blive som en sådan oversvømmelse. Også henvisningen til assyrerkongen er i DO 1992 anbragt mellem tankestreger, hvorved overscetterne angiver, at der er tale om en tilføjelse, der har skullet prcecisere, hvad billedet er et billede på. I det tekstkritiske apparat er der ganske enkelt forslag om at slette omtalen af kongerne, selv om der ikke er noget tekstbelœg for det (jf. BHS 6b-b og 7b-b). Men selv om udløgningen skulle 
vœre senere, passer den godt ind i såvel den littercre kontekst, Denkschrift, som den historiske kontekst.

Kontrasten mellem de sagte, rindende vande og de vœldige strømme angiver modsctningen mellem Jahve og assyrerkongen. Her er det ikke Jahves styrke, der pointeres. Det er assyrerkongens vœldige hœrstyrker, der fremhœves med billedet af oversvømmelsen, da det netop er den, der skal skrœmme folket. Men kontrasten mellem de to er som kontrasten mellem det livgivende og det dødbringende vand. Samtidig skabes der dog også en vis sammenhang mellem de to, når de begge kan sammenlignes med vand, og valget står mellem disse to former for vand (se Kirsten Nielsen 1986, 101-12).

Mens der i v. 6 ikke scettes navn på folket, det er blot העם הזה, bruges navnet Juda i v. 8. Det er dette landområde, som skal oversvømmes af den valdige flod. Juda er ikke et område, hvor oversvømmelser hører til de største trusler; det er tvœrtimod fravœret af vand, der truer med at ødelœgge landet og gøre det til en ørken. Derfor virker billedsproget ekstra stcrkt, når det maler billedet af et oversvømmet Juda og dermed beskriver, hvordan assyrerkongens hare vil oversvømme landet. At vandet skal nå helt op til halsen på befolkningen viser, hvor dødsensfarlig assyrerkongen er. Men hvis vandet netop stopper ved halsen, så er der stadig en vigtig rest tilbage, hovedet! De er tat ved at miste livet; men de holder stadig hovedet oven vande.

Det sidste udsagn i v. 8 gentager truslen. Vandet, der breder sig, sammenlignes nu med vingerne på en fugl. Fuglevinger kan bruges som billede på beskyttelse, således som det er tilfœldet i udtrykket i dine vingers skygge, SI 36,8 (se også SI 57,2; 61,5; 63,8 eller brugen af vingebilledet i Rt 2,12). Men billedet af en stor fugl med udbredte vinger kan også bruges negativt som i Jer 49,22, hvor den store ørn kommer for at slå ned på sit bytte. For at afgøre, hvordan teksten skal forstås, må man først bestemme, hvad suffixet i כנפיו går tilbage til. I DO 1992 er det tolket således, at det er flodens vinger, dvs. assyrerkongen, og det vil indebcere, at vingerne skal tolkes negativt. Men i så fald opstår der en modsigelse mellem billedet og det afsluttende עמנו אל, Gud med os.

En anden mulighed er derfor, at dette udsagn oprindelig har hørt hjemme i en anden sammenhceng, hvor det ikke er flodens vinger, men derimod Jahves vinger, der yder beskyttelse og dermed billedligt udtrykker, hvad der også ligger i navnet Immanuel. Men det krœver netop, at suffixet går tilbage til Jahve. Jahve er ganske vist subjekt i v. 7, men sprogligt er det nœppe sandsynligt. Ved at kombinere flodbilledet, fuglebilledet og Immanuel, har redaktorerne skabt en tekst, hvor lœeseren må opleve en vis spcending mellem positivt og negativt, men dog fornemme, at bag de store 
politiske begivenheder står netop den Jahve, som tidligere har lovet kong Akaz, at hans slcegt skal overleve, for der skal fødes en søn, der bcerer navnet Immanuel. Uanset hvor voldsom en straf, Jahve vil sende over sit folk i form af assyrerkongen og hans vœldige hcer, så er der stadig en overlevelsesmulighed. Ikke for alle, men dog for den rest, der stadig har hovedet oven vande og ncerer tillid til, at Gud er med os. Og så vil den negative tone måske alligevel kunne fornemmes. For når de har forkastet Jahve, er det vel ikke ubetinget positivt at blive mindet om, at Jahve er den ncrvcrende Gud? Ganske som navnet Shearjashub kan Immanuel derfor opfattes som dobbelttydigt.

Tilbage til indholdsfortegnelsen

\section{Jes 8,9-10}

\section{Tekstkritik}

Der er ingen grund til at rette i teksten.

\section{Karakteristik}

Oraklet, der er henvendt til de fremmede folkeslag, indeholder en advarsel mod at lœage planer om angreb. Stilen er ironisk. Folkene opfordres til at gøre det, som netop ikke kan lykkes for dem. Grunden hertil er Immanuel, Gud med os. Oraklet minder om Jes 7, 1-9, hvor profeten beroliger kong Akaz med, at kongerne fra Syrien og Nordriget ikke skal få held til at erobre byen. Nœrmeste parallel til denne del af den jesajanske forkyndelse er SI 2, hvor salmisten undrende spørger, hvorfor folkeslagene løgger planer om at gøre oprør mod Jahve og hans salvede, SI 2,1. Ethvert oprør er omsonst, eftersom Jahve har indsat "sin søn" som konge på tronen i Jerusalem (se ncermere til fortolkningen af SI 2 i DKDS II). Både SI 2 og den jesajanske forkyndelse bygger på folkekampmyten, der er en vigtig del af Zionideologien. Ifølge denne myte vil de fremmede folk angribe Jerusalem, men Jahve vil slå angrebet tilbage og frelse sin by og sit folk (se også SI 46 og 48).

\section{Struktur}

9-10 Ironisk opfordring til at gøre klar til en krig, der ikke vil lykkes. 


\section{Fortolkning}

9-10

I dette orakel forkyndes det endnu engang, at folket er under Guds beskyttelse. Dermed genoptages tanken fra Jes 8,1-4, hvor assyrernes sejr over Syrien og Nordriget bliver til frelse for Juda. Mens Jes 8,1-4 prœciserer, hvilke riger der er tale om, er Jes 8,9-10 holdt i en generel sprogbrug, som svarer godt til folkekampmytens form og indhold. Det er simpelthen alle folkeslag, der har rottet sig sammen mod Zion. Stilen er knap og i v. 9 prœget af brugen af imperativ. Folkene får befaling om at slutte sig sammen, men derpå skal de blive grebet af rœdsel. Grunden til radselen må vœre, at det i realiteten er Gud selv, de samler sig imod. At de sammensvorne skal gribes af raedsel er også motivet i SI 48,5-7, hvor det er Jahves nœrvœr, der skaber deres paniske angst. Det siges ikke, hvad alle jordens fjerne egne skal lytte til, men det må vœre selve oraklet med pointen: Immanuel. Det er os, Juda, Gud støtter.

Befalingen til at spœnde bœelte (jf. Jes 5,27) er en opfordring til at gøre sig klar til krigen. Men hvor det spœendte bœilte normalt konnoterer kampmod og sejrsvilje, er resultatet her det stik modsatte. De skal gribes af frygt. Og om den frygtsomme kriger gcelder også, at han har mistet kampgejsten.

I v. 10 følger en befaling om at lœegge råd op. Der tœenkes på de planer, kongerne laver i fœellesskab. Men disse planer skal blive brudt. Verbet פרר bruges ofte sammen med glosen pagt, ברית, fx Gen 17,14; Jes 24,5; 33,8. De planer, kongerne løgger sammen, indeholder derfor også en pagt om at gå i krig i fœllesskab. Det er disse fœlles aftaler, der nœvnes i det følgende, men som ikke skal lykkes. Udtrykket לא יקום, det skal ikke lykkes, minder om oraklet i Jes 7,7, hvor Jahve om Syriens og Nordrigets planer om at erobre Jerusalem siger: לא תקום. Men hvor man i forbindelse med Jes 7,7-9 selv skal drage den slutning, at når planerne ikke skal lykkes for de to konger, så er det fordi Jahve selv (eller i det mindste hans udvalgte konge) er Judas og Jerusalems hoved, så er begrundelsen klart angivet her i Jes 8,10: עי עמנו אל, fordi Gud er med os.

Immanuel er navnet på den kongesøn, som Jahve lover kong Akaz i Jes 7,14, og som er garanten for det evige kongedømme, som Jahve lovede David, 2 Sam 7,1 1-16; SI 89,20-38. Lœst med disse tekster som intertekst for Jes 8,10, bliver henvisningen til Immanuel et tilsagn til kongen om, at Jahve vil tage sig af Davidsslaegten i al fremtid. 


\section{Jes 8,11-15}

\section{Tekstkritik}

$11 \mathrm{a}$

I stedet for בחזקת, der betyder "som griben" lœeses בחזקת, der betyder "ved griben", og som giver bedre mening i konteksten. Denne løesning støttes af flere hebraiske manuskripter og følges af DO 1992. Årsagen til fejlskrivningen er formentlig, at de to bogstaver z og z ligner hinanden meget.

\section{Karakteristik}

Oraklet er en advarsel. Det er ifølge v. 11 vendt mod profeten, som Jahve har grebet fat i, men i sin ordlyd, v. 12-15, er det rettet mod flere personer. Som andre steder i Denkschrift skelnes der her mellem profeten, en mindre gruppe og så folket mere generelt. Det er denne mindre gruppe, der formanes til ikke at frygte de forskellige sammensvcrgelser, som folket i almindelighed går og snakker om og er angst for. Denne mindre gruppe svarer til den rest, der skal vende om, Jes 7,3. Problemet er, at folket kun har øje for de jordiske kongers magt, derfor glemmer de den, de for alvor bør frygte, nemlig Jahve selv. Det er ham, de skal hellige.

Det er en central tanke i den jesajanske forkyndelse, at det er Jahve, der leder historiens gang, og at historiens gang bestemmes af forholdet til Jahve. Derfor skal de hverken frygte eller scette deres lid til de fremmede konger, hvad enten det er stormagterne, Assyrien og Egypten, eller nabolandene, Syrien og Nordriget. Det er gudsforholdet, der er afgørende for, hvordan Juda skal klare sig, når fjenderne truer, og ikke militcre forhold (jf. at Akaz vœlger at taenke strategisk, da Jerusalem er truet, og i stedet for at henvende sig til Jahve går ud og inspicerer vandledningen, Jes 7,4). Det medfører, at Jahve både kan blive en helligdom for dem, der frygter ham, og en snublesten for dem, som ikke frygter ham. I v. 14 er folket ikke blot Juda, men begge rigerne, Nordriget og Juda, og der skal vare mange, som falder over snublestenen.

Hvem det så er, der holder fast ved Jahve, og hvor få de er, siges ikke. Men det efterfølgende orakel handler om Jesaja selv, hans disciple og hans børn. Dette kunne tolkes sådan, at den rest, der tœnkes på i Jes 8,11-15, også er meget begrcenset (se nœrmere i kommentaren til Jes 8,16-18).

Sprogligt er der en ncer forbindelse mellem metaforerne i v. 14-15 og Davids Salmer. Metaforen klippe er velkendt fra salmerne, men anvendes anderledes. Hvor salmisten i SI 62,3 tillidsfuldt 
kan erklœre, at Jahve er hans klippe og frelse, så bliver klippen her til noget, man snubler over. Og mens salmerne taler om fjenderne som nogen, der lcegger fœlder for den fromme, fx SI 140,6, er Jahve her selv anskuet som en fœlde og et fanggarn. Teksten genbruger velkendte forestillinger, men drejer dem 180 grader og skaber derved en overraskelseseffekt.

\section{Struktur}

11 Jahves henvendelse til profeten for at advare ham.

12-15 Advarsel mod at frygte jordiske magter i stedet for Jahve og derved blive bragt til fald.

\section{Fortolkning}

11

Verset prœciserer, ved hjœelp af sendebudsformlen: כה אמר יהוה, så siger Jahve, at det følgende orakel er Jahves ord til profeten. Omstcendighederne, hvorunder profeten fik overdraget budskabet, beskrives med udtrykket, at Jahves hånd greb profeten. Hermed hentydes formentlig til en ekstatisk oplevelse. I Ez 1,3 indledes profetens syn med, at Jahves hånd kom over ham, mens det i Ez 33,22 indebarer, at profeten får talens brug igen efter en periode som stum. I Jes 8,11 angives det, at Jahves ord er henvendt til profeten og er en advarsel mod at gøre, som folket gør. At gå på folkets vej betyder at handle som de. Ordet vej, דרך, bruges ofte om en persons livsvej og dermed deres handlinger, fx SI 1,1 og 119,3. Derudover fungerer verset ved hjcelp af udtrykket לאמר som introduktion til de følgende vers.

\section{2-15}

I v. 12 er Jahves ord rettet til en gruppe personer, som tiltales i anden person flertal. At denne gruppe ikke er identisk med folket som helhed fremgår af, at der skelnes mellem dem, der tales til, "I skal ikke..." og dette folk, som begår den fejl at tale om sammensvcergelser, hvor der ikke er grund til det. De ser konspirationer alle vegne og bliver grebet af angst. Hverken profeten, v. 11, eller de nu tiltalte, v. 12, skal gøre som folket i al almindelighed. Det siges ikke, hvad det er, folket betragter som sammensvœrgelser. Pointen er, at de ved at lade sig skrœmme af politiske intriger afslører deres manglende tillid til Jahve. Gentagelsen af ordet for sammensvargelse, קשר, understreger dets betydning. Også det nœste udsagn indeholder gentagelser, idet roden ירא, frygte, bruges to gange, og glosen 
תיראו Betyder stort set det samme og står ganske parallelt til Bעריצו forstcerker virkningen af det sagte.

Efter advarslen om, hvad de ikke skal gøre, følger i v. 13 en formaning til, hvad de skal gøre, nemlig hellige, תקדישו, Jahve. Jahve omtales som Hœrskarers Jahve, det for Jerusalemteologien typiske Gudsnavn. Hvad helligelse indebcerer i denne sammenhceng fremgår af opfordringen til at vise œrefrygt for Jahve. Glosen for frygt er en gentagelse af samme glose i v. 12, hvorved der skabes en klar kontrast mellem folkets frygt, מוראו, som gaelder sammensvaergelser, og jeres frygt, מוראכם, der skal gœlde Jahve selv. I sidste tilfœlde udvides beskrivelsen af frygten med endnu et substantiv for frygt, מערצכם, samme rod som i v. 12, som i øvrigt rimer på מוראכם.

Forholdet til Jahve vil ifølge v. 14 få afgørende konsekvenser for folket. At Jahve skal vœre en helligdom - her er det roden קדש, der gentages - må i første omgang opfattes som noget positivt. Helligdommen er stedet for Jahves ncervcer, og ud fra gammeltestamentlig tankegang er helligdommen også et asylsted, hvor man kan finde beskyttelse, fx Ex 21,12-14; 1 Kong 1,50 og 1 Kong 2,28. Men samtidig er det hellige ikke kun fascinerende, det er også skrœmmende. Det skrœmmende aspekt udtrykkes i det følgende ved hjœlp af forskellige metaforer. Ud over at vare en helligdom skal Jahve vœre en anstødssten. Hermed vendes der op og ned på de forventninger, man normalt har til Jahve. Jahve skulle netop vœre den, der sørger for, at man ikke snubler. I SI 91,12 er det hans engle, der skal "bcere dig på hœender, så du ikke støder din fod på nogen sten" (jf. også billedet af Jahve som den gode hyrde, der sørger for, at ens fod ikke vakler på vandringen, SI 121,3). Klippen som metafor for Jahve kendes fra forskellige salmer, SI 18,3.32.47; 62,3; 89,27, hvor den angiver trofasthed og sikkerhed. Men i Jes 8,14 vendes billedet om, så klippen bliver noget, man snubler over i stedet for at kunne søge tilflugt på den.

I v. 14 prœciseres det, at advarslen gcelder begge Israels huse, dvs. Nordriget såvel som Juda og herunder ikke at forglemme, Jerusalems indbyggere. Oraklet passer derfor godt ind i Jesajas Denkschrift, som fortceller om den for både Nordriget og Sydriget kritiske situation i slutningen af 730'erne f.Kr.. Med endnu to metaforer for Jahve udpensles den fare, de befinder sig i. Jahve skal blive en fcelde, פוקש, מוקש, for dem. Billedet er et jagtbillede, hvor jcegeren fanger dyrene ved hjœelp af fcelder eller snarer. I Davids Salmer bruges denne metaforik ofte om salmistens fjender og indgår i bønssalmer, hvor Jahve bønfaldes om at gribe ind og redde den bedende, fx SI 141,9 (se også SI 69,23 og 91,3). Her i Jes 8,14 er Jahve tvœrtimod selve fœelden, der skal fange dem. Denne omvending af motiverne svarer godt til budskabet i Jes 6 , hvor profeten sendes for at forhcerde fol- 
ket. Jahve selv skal vare en hindring for flertallet af folket. Men ligesom de mange domsorakler i kapitlerne forud for Jes 6 er med til at retfcerdiggøre Jahves straf over sit eget folk, således fungerer Jes 8,5-8 som en understregning af, at folket selv har forkastet Jahve.

Konkluderende hedder det i v. 15, at mange skal snuble og falde, lemlastes og fanges i snaren. På trods af advarslen vil mange komme til kort i forholdet til Jahve. Men netop omtalen af de mange åbner muligheden for, at en rest lader sig advare. Det er ikke folkets totale udslettelse, der forudsiges.

Tilbage til indholdsfortegnelsen

\section{Jes 8,16-18}

\section{Tekstkritik}

Der er ingen grund til at rette i teksten.

\section{Karakteristik}

Med dette afsnit genoptages et af motiverne fra Jes 6, selve den profetiske opgave. Jes 6 fokuserer indledningsvis på profetens egnethed til at tale. Selv erklœrer han sig uegnet, da hans lœber er urene. Han må derfor også tie (se ncermere om tolkningen af נדמיתי s. 105). Efter den nødvendige renselse af lœeberne sendes profeten ud for at forhœrde folket, dvs. i stedet for at skabe lydhørhed for budskabet skal han forhindre modtagelsen af Jahves ord. Motivet tie eller tale og dermed muligheden for at folket skal høre og forstå, indgår også i Jes 8,16-18. Profeten meddeler, at han vil binde til for budskabet, dvs. ophøre med at forkynde. Budskabet skal dog fremover bevares af hans disciple. Det begynder med tavshed og nu rundes der af med tavshed (se nœrmere om omfanget af Denkschrift s. 99-101). Men ligesom den tavse profet trods alt blev sendt ud med et budskab i Jes 6, så indeholder Jes 8,18 også et element af forkyndelse, idet Jesaja og hans børn skal fungere som tegn og varsler. Tœnkes der hermed mere prœeist på de to sønner, Shearjashub, en rest vender tilbage/om, og Maher-Shalal Hash-Baz, hastigt bytte, hurtigt rov, er det deres navne, der forklarer tegnfunktionen, ligesom Jesaja selv gennem sit navn, Jahve frelser, er bcerer af et budskab. Temamcessigt skabes der hermed en cirkelkonstruktion, hvor begyndelsen af Jesajas virke og den foreløbige afslutning danner rammen om tre vigtige episoder fra tiden omkring den syrisk-efraimitiske krig.

Udover spœndingen mellem at tie og tale tematiseres en anden spœending i dette korte afsnit. Spcendingen er indbygget i det gudsbillede, afsnittet formidler. I v. 17 udtaler profeten, at han vil 
vente på Jahve, som har skjult sit ansigt, mens det af v. 18 fremgår, at Hœrskarers Jahve er den, der bor på Zions bjerg. Jahve er altså både den, der bor på Zion (jf. at Jahve i Jes 6 viste sig for profeten $\mathrm{i}$ templet) og den, der skjuler sig (jf. at forhœerdelsesbudskabet indebcerer, at folket ikke forstår frelsesoraklerne).

\section{Struktur}

16 Profetens erklœring om, at han vil tillukke og opbevare budskabet.

17-18 Profetens, disciplenes og sønnernes funktion som tegn, mens Jesaja venter på Jahve.

\section{Fortolkning}

16

Ophøret af profetens forkyndelse beskrives billedligt. Det første ord i v. 16, צור, kan enten løeses som en imperativ af roden צרר, eller som en infinitiv absolutus af roden צור. Begge rødder kan bruges om at binde til for noget. Parallelverbet, חתום, som betyder at forsegle, er vokaliseret som imperativ. Ændres vokalen under første bogstav til qames, er det derimod infinitiv absolutus. DO 1992 har valgt at overscette begge steder som infinitiv absolutus brugt om første person. Bevarer man teksten ucendret, må man ud fra parallelkonstruktionen opfatte צור som imperativ. I så fald er der tale om en befaling fra Jahve. Ligesom Jahve var den, der sendte profeten ud med et budskab i Jes 6,9, er det nu בלמדי i Jahve, der befaler ham at lukke til for budskabet. I konsekvens heraf må første person suffikset gå på Jahve selv, der her omtaler disciplene som sine disciple. En anden mulighed er, at בלמדי her betyder min (store) lœre (amplificativ pluralis), og at det foranstillede a skal opfattes som בessentiae, der specificerer ordet תורה. Teksten skal så oversœettes: "Bind til for budskabet, forsegl belœringen, min store lœre." Vœegten lœgges dermed på det budskab, der skal bevares til senere tider, hvorefter profeten fortscetter med at fortcelle i første person om sin egen reaktion på denne befaling.

Billedet af tilbindingen af budskabet minder om tilbindingen af en pung. En pung hedder på hebraisk צרור og nœevnes fx i Job 14,17, hvor Job siger, at hans overtrcedelse "ligger forseglet i pun-

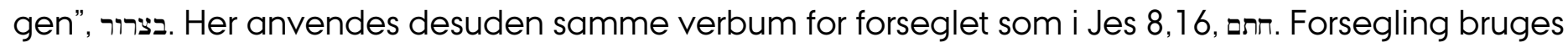
i Jes 29,11 om at forsegle noget skriftligt (se også Jer 32,10-14.44). Nogle forskere har derfor foreslået, at omtalen af forseglingen skulle vare en henvisning til et tidligt dokument med dele af Jesajas forkyndelse. At budskabet skal forsegles i mine disciple, בלמרי, taler mod en sådan bogstavelig opfat- 
telse. Billedligt er disciplene de beholdere, budskabet skal bevares i. Vœlger man i stedet den ikke helt så sandsynlige tolkning, min (store) lœere, kan muligheden holdes åben. Forkyndelsen skal ikke blot ophøre, den skal også opbevares, og det har sine grunde. For når de ord, Jahve har sendt profeten med, begynder at gå i opfyldelse, så skal folket forstå, at Jahve hele tiden har styret de politiske begivenheder. Tingene sker ikke tilfœldigt, men efter Jahves plan.

Der anvendes to gloser til at betegne det budskab, profeten er sendt med, dels תעודה, der betyder bevidnelse, dvs. at noget er sikkert bevidnet, dels תורה, som både bruges om lov og mere generelt om lœre. Begge gloser omfatter i denne sammenhœeng, hvad profeten har formidlet i sit Denkschrift. Og et karakteristisk trœk ved hans virke er jo netop, at det er offentligt. Han har ikke talt i det skjulte. Sønnerne går rundt som levende udtryk for centrale tanker i forkyndelsen, og tavlen med navnet på den ene af sønnerne stod frit til skue og var endda bevidnet af trovardige personer nœr på konge og tempel.

\section{7-18}

I de følgende to vers fortceller profeten om den rolle han selv og hans børn skal indtage i fremtiden. Der tcenkes formentlig ikke blot på sønnen, Maher-Shalal Hash-Baz, men også på disciplene som sønner af deres lœeremester. Som det første markeres, at profeten fastholder sit nœre forhold til Jahve. Profeten vil vente på Jahve. I SI 33,20 bruges verbet חכה i en hymnisk kontekst, hvor salmisten udtrykker både sin lœngsel efter Jahve og sin glœde over, at Jahve er "vor hjœelp og vort skjold". Verbet קוה, der har samme betydning, blev brugt i vingårdslignelsen, hvor det var Jahve, der ventede ret, men i stedet oplevede uret, Jes 5,7. Derpå beskrives Jahve. I stil med SI 33,20 ville man forvente, at profeten ville pege på Jahves trofasthed som grund til sin venten, men hvad han siger om Jahve er, at han har skjult sit ansigt for Jakobs hus. Når Jahve skjuler sit ansigt, giver det normalt anledning til klage, sådan som det er tilfœldet i den klassiske bønssalme SI 13,2 (se også klagen i SI 44,25, som er en kollektiv bønssalme, samt tilbageblikket på nøden i takkesalmen, SI 30,8, hvor salmisten blev grebet af radsel, da Jahve skjulte sit ansigt for ham). At Jahve har skjult ansigtet for Jakobs hus, dvs. sit folk, har netop vist sig gennem folkets forhœrdelse. Men Jesaja holder fast ved, at der stadig er håb. Og netop dette håb skal han og hans børn bevidne.

Af v. 18 fremgår det, at ligesom Jesaja ved sit navn bœrer det budskab, at Jahve frelser, kan sønnen gennem sit navn bevidne, at Jahve har forudset og planlagt både Damaskus' og Samarias fald. At det er Jakobs hus og Israel, der nœvnes i disse vers viser, at profeten ikke kun 
tcenker på Juda, men på både Nordriget og Juda. Jakob med tilnavnet Israel er stamfar til alle tolv stammer.

Om Jahve siges endelig, at han er Hœerskarers Jahve, som bor på Zions bjerg, dvs. i Jerusalems tempel. Udgangspunktet for Jesaja er tydeligvis Jerusalem og templet. Det er da også dertil folkene skal strømme if. Jes 2,1-5. Og nok har Jahve skjult sit ansigt, men han bor stadig midt i sit folk. Denne dobbelthed i beskrivelsen af Jahve som både fravœrende og nœrvœrende stemmer godt overens med den spœendingsfyldte forkyndelse, profeten er sendt med: både trusler om kommende straf og løfter om en ny fremtid. For der vil trods alt vare en rest tilbage at bygge videre på.

Tilbage til indholdsfortegnelsen

\section{Jes 8,19-22}

\section{Tekstkritik}

Der er ingen grund til at rette i teksten.

\section{Karakteristik}

De følgende vers er redaktionelle forsøg på et uddybe et af temaerne i Denkschrift, den kommende ulykke. I v. 19-20 polemiseres der mod dem, der tror, at man ved at mane de døde til live kan få viden om fremtiden. Over for tilliden til den slags peges der i stedet tilbage på det, som Denkschrift har videregivet: belceringen og budskabet (jf. de samme gloser i Jes 8,16). Nœste afsnit, v. $21-22$, beskriver den fortvivlede situation, som folket skal opleve, når Jahve sender sin straf over dem. Hvem det er, som skal gå sulten omkring og endda forbande sin konge og sin Gud, siges ikke. Den håbløse situation karakteriseres afslutningsvis ved gloser som mørke og mulm. Dermed skabes baggrund for det følgende orakel, der forkynder ophøret af mørket.

\section{Struktur}

19-20 Afvisning af dødemanerne og opfordring til at holde sig til Jahves belcering.

21-22 Den kommende ulykke, hvor den lidende midt i mørket vil forbande sin konge og sin Gud. 


\section{Fortolkning}

19-20

Den første redaktionelle tilføjelse knytter tydeligt til ved det netop forudgående. Baggrunden må vœre, at folket ikke har lyttet til Jesajas forkyndelse (jf. forhœrdelsestanken), men i stedet har forsøgt sig med dødemaneri. Afsnittet er formet som en tcenkt samtale, hvor nogen prøver at lokke andre til at gå alternative veje. Glosen האבות er i DO 1992 oversat ved dødemanere, men betegner de dødes ånder, som scrligt kyndige skulle kunne mane frem og rådspørge. At disse ånder også kan omtales som guder viser den positive holdning, som nogle har haft til disse ånder. Deres argument, at det jo er for at gavne de levende, at man skal søge til ånderne, peger ligeledes på en positiv opfattelse. Men generelt fordømmes den slags i Det Gamle Testamente. Bedst kendt er nok eksemplet med Saul, der kort før sit selvmord, som tegn på den yderste fortvivlelse henvender sig til en spåkvinde for gennem hende at få kontakt til profeten Samuels ånd, 1 Sam 28,7. Denne beretning indgår i fortcellernes påvisning af, hvordan og hvorfor Saul mister magten til fordel for David. Også her i Jes 8, 19-20 afvises denne mulighed.

Sandsigerne, הידענים, har, som navnet siger, en scrlig viden. Lœest parallelt med de dødes ånder må det betegne nogle ånder og ikke de mennesker, der forsøger at kontakte dem, sådan som DO 1992 forstår det. Også disse scrlige ånder og det, de kan sige - de hvisker og mumler - afvises. Derfor skal de, der bliver opfordret til at søge alternativ hjœelp, i stedet henvise til den belcring og det budskab, som Jesaja vil bevare hos sine disciple, Jes 8,16. Selv om situationen ser håbløs ud, og de ikke engang har udsigt til at opleve morgenens komme (jf. Job 3,9), skal de ikke lade sig forlede, men holde fast ved Jahve.

\section{1-22}

Det praciseres som navnt ikke, hvem parterne i den fiktive samtale i v. 19-20 er. Det samme gcelder ham, der omtales i de to nceste vers. Situationen er tydeligvis fortvivlende. At han drager om i landet og ikke slår sig ned, må skyldes, at han forgceves leder efter føde. En katastrofe har ramt landet, og i sin vrede forbander han både kongen og Gud. At forbande både sin konge og Gud er en alvorlig forbrydelse, som straffes med døden, således som det fremgår af de falske beskyldninger mod Nabot for at "forbande Gud og kongen", 1 Kong 21,10.13. Formuleringen er her i Jes 8,21 vendt om, så kongen kommer før Gud, muligvis for at skabe lidt større afstand mellem verbet forbande og 
Gud selv. I 1 Kong 21,10.13 forsøger man noget lignende ved at anvende verbet velsigne i stedet for verbet forbande, dvs. ved at bruge en eufemisme.

At Gud som skaberen også kan sende hungersnød over landet, må vœre grunden til, at han lader vreden gå ud over Gud. Gud, som under normale omstcendigheder velsigner landet med frugtbarhed, har i stedet ramt det med hungersnød, fx Gen 12,10 eller Rt 1,1. At han også forbander kongen, kan skyldes, at man forestillede sig, at kongen som Guds reprcsentant på jorden også havde et medansvar for naturen. I SI 72 beskrives den ideale konge og den lykkelige tid under ham, hvor retfcerdigheden hersker, fjenderne bøjer sig, og der netop også skal vare overflod af korn i landet, SI 72, 16.

Modsctningen til det velsignede land er ikke blot hungersnøden, men også mørket. Kaos hersker, hvor der før var kosmos. Mørket kendetegner urtilstanden, før Gud bragte orden i kaos ved at skabe lyset, Gen 1,1-3. Nu er lyset borte, uanset hvor han stirrer hen. Forestillingerne minder desuden om dem, der er forbundet med Jahves dag, som i Sef 1,15 netop er karakteriseret ved nød, צרה, og trcengsel, מצוקה.

Der er noget fragmentarisk over disse to vers. Det er ikke til at afgøre, om de oprindelig har hørt hjemme i en anden kontekst, hvor situationen var tydeligere beskrevet, og man måske endda fik oplyst, hvem den omvandrende mand er, og hvilken konge han forbander. Forskerne har forsøgt at rekonstruere forskellige situationer, som versene kunne passe ind i, men uden held. Vigtigere er det nok også at se på den retoriske effekt, teksten har. Netop den manglende prœcision og brugen af motiver fra kaosforestillingerne og tanken om Jahves dag skaber den uhygge, som kendetegner den håbløse situation. Man kan knap nok orientere sig, mørket truer fra alle sider.

Tilbage til indholdsfortegnelsen

\section{Jes $8,23-9,6$}

\section{Tekstkritik}

$2 \mathrm{a}$

Der skal rettes med BHSa fra הגילה (ikke folket) til (jubelen). Rettelsen kan ikke begrundes med henvisning til andre hebraiske tekster eller til gamle oversœttelser, men alene ud fra konteksten. Se ncermere i fortolkningen af verset. DO 1992 retter. 
$6 a$

Ordet לםרבה betyder til mangfoldiggørelse. Man kan se af Qumranversionen, at det egentlig er to ord, der er skrevet sammen til ét: לם og רבה, hvilket også kan ses af brugen af slutnings mem midt i ordet. Det kan gengives: til dem stor. Men mere sandsynligt er det, at de første to bogstaver לם er en dittografi, dvs. at afskriveren er kommet til at gentage de to bogstaver fra det foregående ord שלום. Den danske overscttelse stryger ganske enkelt de to bogstaver og gengiver alene רבה, dvs. stor.

\section{Karakteristik}

Trods kapitelinddelingen udgør Jes 8,23-9,6 en helhed. ${ }^{15}$ Afsnittet er et poetisk formet frelsesorakel, der indledes med en rœkke historiske oplysninger. Baggrunden for Jes 8,23 er assyrerkongen Tiglat Pileser Ill's erobring af store dele af Israel, Nordriget, i 732-731 f.Kr. Som assyriske provinser lever disse områder billedlig talt i mørke, kaos, men profeten forkynder, at Jahve vil bringe mørket og den skam, der følger med at vœre underlagt en fremmed hersker, til ophør. Efter den omhyggelige opregning af de pågceldende områder fortscttes der med billedet af lyset, der skinner i mørket, Jes 9,1. Også her er det landet, der fokuseres på. Efter en skildring af den jubel, der skal lyde, v. 2, gives begrundelsen for glœden: Fjendens magt er blevet brudt, og der er født en ny konge, som vil vœre i stand til fortsat at sikre freden og retfœrdigheden i riget til evig tid. Oraklet har som forudsctning forestillingerne om den ideelle konge (jf. SI 72 samt SI 2). At kongen er indsat af Gud selv og fungerer på hans vegne fremgår af den afsluttende lovprisning af Hœrskarers Jahves nidkcerhed som den egentlig årsag til vendingen fra mørke til lys, fra kaos til kosmos.

Oraklet må med sine pracise geografiske angivelser stamme fra et tidspunkt efter assyrernes erobring af de nœvnte landområder. Men det er ikke muligt at give en mere prcecis datering. Nogle forskere peger på Hizkijas tronbestigelse som det tidspunkt, hvor håbet om en ny fremtid stiger. Der er dog usikkerhed om, hvorvidt Hizkija kommer til magten som sin fars medregent allerede i 728 f.Kr. eller først ved faderens død i 715 f.Kr. Under alle omstcendigheder markerer 715 f.Kr. begyndelsen på en mere antiassyrisk politik i Juda. En langt senere mulighed er tiden under kong Josija, 639-609 f.Kr., hvor assyrerriget går til grunde.

Forventningerne til den kommende kongesøn, Jes 9,5-6, kan sammenlignes med skildringen i Jes 11,1-9 af Isajs skud (se nœrmere i faktaboksen om Messiasforestillingerne s. 174-175). Begge

\footnotetext{
${ }^{15}$ Kapitelinddelingerne er ikke en del af den hebraiske tekst, men stammer fra 1200 tallet e.Kr. Se nœrmere i $G B L$ under "Kapitel, kapitelinddeling".
} 
steder er der tale om en konge af Davids slœgt, som skal styre sit rige med indsigt og styrke og skabe et vœldigt fredsrige. Denne konge er i disse tekster ikke beskrevet som en fjern skikkelse, men med kongedømmets fald i forbindelse med det babylonske eksil måtte man se i øjnene, at denne konge endnu ikke var kommet. Ganske vist havde forhåbningerne i 8. århundrede f.Kr. formentlig samlet sig om den kommende kong Hizkija og senere igen i 7. årh. f.Kr. om kong Josija. Men for ingen af dem var det lykkedes at oprette et stort og langvarigt Davidsrige. Opfyldelsen lod vente på sig, men forjœttelserne blev ikke glemt. Interessen for dynastiets fortsatte beståen skaber desuden forbindelse tilbage til Jes 6,13 samt til Immanuelsforjœttelsen i Jes 7,10-17.

\section{Struktur}

8,23-9,1 Forjcettelse om en lys fremtid for tre undertrykte landområder.

9,2 Lovprisning af Jahve som årsag til glœden.

9,3-6 Begrundelse for gløden: befrielsen fra fjenderne og fødslen af en ny konge.

\section{Fortolkning}

\section{8,23-9,1}

Den politiske baggrund er omtalt i 2 Kong 15,29, hvor det hedder: "I Israels konge Pekas regeringstid kom assyrerkongen Tiglat-Pileser og indtog ljjon, Abel-Bet-Ma'aka, Janoa, Kedesh, Hasor, Gilead og Galil, hele Naftalis land, og førte indbyggerne i eksil til Assyrien." Det drejer sig om årene 732-731 f.Kr., hvor Arams og Efraims oprør mod assyrerkongen førte til en assyrisk straffeekspedition. Damaskus blev erobret i 732 f.Kr., og store dele af Syrien samt dele af Nordriget blev lagt ind under Assyrien som provinser. At have status af provins betyder, at der indscettes en assyrisk guvernør, der styrer landet fuldt ud. I Jes 8,23 omtales nogle af disse provinser: Zebulons og Naftalis land er vigtige dele af de landområder, som Tiglat-Pileser erobrede. Vejen langs havet betegner den assyriske provins Dor, der ligger langs Middelhavskysten. Landet på den anden side af Jordan er Gilead, provinsen Gal'aza; mens Folkeslagenes Galilca er provinsen Megiddo, der omfatter Jizreelsletten og et område nordpå. Samaria bliver ved denne lejlighed skånet for ødeløggelse, men området bliver vasalstat og får en assyrervenlig konge. Juda bliver ligeledes gjort til vasalstat under assyrerkongen. Som vasal opretholder man en friere status end en provins. Den lokale konge beholder sin trone, men betaler årlig tribut (skat) til assyrerkongen. 
Forjœettelsen betyder en ophœvelse af assyrerkongens herredømme og den skam, der følger med at miste frihed og selvstcendighed. Med v. 1 sammenfattes det glœdelige budskab i billedet af lyset, der skinner i mørket. Det er så generelt et billede, at det vil kunne genbruges i mange forskellige situationer. Gloserne אור og משך bruges i den første skabelsesberetning til at markere indledningen på selve skabelsen. Før skabelsen herskede mørket, חשך, men med befalingen om at lyset, אור, skal bryde frem, begynder den velkendte verden at tage form, Gen 1,2-3. Perioden under assyrerne kan derfor sammenlignes med en kaostid. Først når friheden er genvundet, er kosmos vendt tilbage (jf. brugen af samme metaforik i Det Nye Testamente om Jesu fødsel, Joh 1,1 - 13).

Udtrykket ארץ צלמות, mørkets land, står parallelt hermed og betegner dødsriget, Sheol (jf. Job 10,21-22). Midt i den dødslignende tilstand skal lyset skinne frem. Ud over at vœre skabelsesmorgenens lys kan lyset også vœre metafor for Jahve selv. I Jes 10,17 kaldes Jahve for Israels lys. Lyset betegner derfor Jahves narvar og dermed hans velsignelse (jf. Num 6,25, hvor Jahves ansigt lyser over den, der velsignes).

\section{2}

At Jahve selv er årsagen til glœeden fremgår tydeligt af det følgende vers, der henvender sig direkte til Jahve og priser ham, ganske som man gør i en takkesalme, fx Jes 12. At glœden finder sted for Jahves ansigt peger på, at folket møder op ved templet, Jahves bolig, for at udtrykke taknemmelighed over befrielsen. Glœden sammenlignes for det første med høstgløeden, hvor man ifølge gammeltestamentlig lovgivning netop skulle valfarte til helligdommen med sine ofre (jf. Ex 23,14-17, se også SI 126,5-6). For det andet nœvnes den glœde, man oplever, når man sejrer i krig og deler byttet. At byttedeling indgår som en vigtig del af sejren fremgår fx af Dom 5,30 (se også SI 1 19, 162).

\section{$3-6$}

Herefter følger tre begrundelser for glœeden, alle indledt med et fordi, כי, v. 3, 4 og 5. Befrielsen fra fremmedherredømmet sammenlignes i v. 3 med det at blive fri fra slaveri. Glosen 2 , byrde, som i DO er oversat ved tyngende, bruges også i Jes 10,27 og i 14,25 om den tyngende byrde, et fremmedherredømme er. Når der tales om et åg, der tynger dem, er forestillingen hentet fra landbruget. Det er trœkdyr, der forsynes med et åg, så de kan trckke en plov eller en vogn efter sig. Åget består af en trœstang, som ligger over skuldrene på dyrene, og nogle stcnger, der går ned langs kroppen. Åget er et hyppigt anvendt billede for undertrykkelse. Israelitterne var således som dyr under åget, 
da de var slaver i Egypten, men Jahve "brød jeres åg og lod jer gå med rank ryg", Lev 26,13 (se også om babylonernes åg i Jes 47,6; Klages 1,14 samt Jer 27-28, hvor åget indgår i en symbolhandling). Åget kan dog også opfattes bogstaveligt som det åg, en slave får over skulderen for at kunne bœre en tung byrde.

Med til undertrykkelsen hører slavefogeden, der har opsyn med arbejdet, fx Ex 5,6.10.13-14, og som er udstyret med en stav, så han kan slå dem, der ikke lever op til hans krav. Befrielsen beskrives som det at blive fri for både åget og de slag, som slavefogeden uddeler. Uden sin stav mister slavefogeden sin magt. Henvisningen til Midjans dag skal understrege, at det er Jahve, og ikke mennesker, der står bag befrielsen. Fortcellingen om Gideons krig mod midjanitterne, Dom 7-8, hvor Gideon kun får lov at medbringe 300 mand, har som pointe, at det er Jahve, der giver sejren, Dom 7,7.

I v. 4 skildres krigssejren. Støvlen, סאון, ${ }^{16}$ og kappen er brugt som pars pro toto: Delen betegner helheden. Når støvle og kappe brœndes, så er fjenden overvundet. Samtidig ligger der den kulturhistoriske realitet bagved, at der ifølge reglerne for hellig krig skal løgges ban på fjendernes ejendele. Det betyder, at de ikke tilkommer den sejrende hcer, men Gud selv. Derfor brœndes de som et offer til Guds œre, fx Jos 11,6.9 og SI 46,10. Ilden er desuden et kendetegn ved Jahve. Hans tilsynekomst er omgivet af ild, fx SI 21,10 eller 18,9, hvor Jahves vrede er som flammende ild. Ilden i Jes 9,4 er derfor også på den måde forbundet med Jahve og markerer, at det er hans sejr over fjenderne.

Den tredje grund til glœde er fødslen af en søn, v. 5-6, der snart viser sig at vare en kommende konge, dvs. en kronprins. Sønnen omtales som en gave; det er også her Jahve, der står bag. I to parallelle sctninger forkyndes begivenheden, og det understreges, at det sker for os, לנו. Det er ikke en privat begivenhed, men noget der kommer hele folket til gode. Verset svarer indholdsmœssigt til løftet til kong Akaz i Jes 7,14. Men hvor fødslen ifølge Jes 7,14 endnu var i vente, omend inden for en kortere tidshorisont, er den allerede indtruffet i Jes 9,5. Kongesønnen er født, og dermed er Davidsdynastiet sikret for fremtiden (jf. Davidspagten, 2 Sam 7,12-13 samt SI 89,20-38). Dette giver anledning til glcede.

Mens der i v. 3 var tale om et tyngende åg over skulderen, hedder det i v. 5, at herredømmet skal hvile på kongesønnens skulder. Magtforholdene œndres hermed totalt. Selv om der er tale om en fødsel og fx ikke om en konges tronbestigelse (se SI 2,6-7, hvor kongens indscttelse beskrives

${ }^{16}$ Glosen 0 er et akkadisk låneord, hvilket tyder på, at den fremmede hœr skal forstås som assyrerhœren med dens sœrlige udrustning. 
som en guddommelig "fødsel", formentlig opfattet som en adoption), rettes blikket straks mod barnets rolle som hersker. I Egypten var det fast praksis i forbindelse med en konges indscettelse, at kongen blev udstyret med nye navne, dvs. nogle scrlige tronnavne. I Jes 9,5-6 sker det ved fødslen, hvilket svarer godt til hele symbolnavnemotivet. Når navnet er et tegn, så hører navnet og dets bcerer uløseligt sammen. Det er derfor naturligt, at navnet gives ved fødslen eller ved bebudelsen af en kommende fødsel, Jes 7,14 og 8,1-4.

Tronnavnene understreger den kommende konges indsigt og magt. Det første navn, Underfuld Rådgiver, פלא יועיץ, markerer hans indsigt og magt til at udføre, hvad han beslutter. פלא er således foranstillet objekt for participiet יועיץ פלא Med taenkes der på underfulde handlinger. Normalt er det Jahve selv, der udfører store og underfulde handlinger (se fx overgangen over Det Røde Hav ved udfrielsen fra Egypten, Ex 15,11; SI 78,12), men her er det kongesønnen, der tilløgges en sådan magt. At han er rådgiver betyder, at han kan tage beslutninger og få dem gennemført (se også Jes 11,2, hvor en af de egenskaber, der tillœgges den kommende konge, er רוח עצה, dvs. den ånd, der gør kongen i stand til at tage de rette beslutninger og føre dem igennem).

At den kommende konge er udstyret med guddommelige egenskaber understreges yderligere af det følgende tronnavn: Valdig Gud, אל גבור. Kun her og i SI 45,7, som er en bryllupssalme til brug ved et kongeligt bryllup, kaldes et menneske for Gud. Udtrykket valdig Gud, אל גבור, anvendes i Jes 10,21 om Gud selv, som en rest skal vende om til. At mennesket ifølge Det Gamle Testamente har en lighed med Gud, fremgår af gudbilledligheden i Gen 1,27, ligesom SI 8,6 understreger, at mennesket kun er "lidt ringere end Gud". At netop kongen har en scrlig tœet forbindelse med Gud selv understreges også af tilsagnet til kongen i SI 2,7: "Du er min søn, jeg har født dig i dag."

At kalde en gud for גבור, en glose, der også bruges om en krigshelt, er ikke overraskende i en ncerorientalsk sammenhœeng, hvor guder ofte prises for deres styrke og magt (se fx omtalen af Guds styrke, גבורה, i Jes 33,13; 63,15; SI 54,3 og 89,14).

Med navnet Evigheds Fader, אבי־אר, peges der dels på kongens ansvar for sit folk dels på varigheden af kongedømmet. Fadernavnet implicerer ansvar for børnene og lydighed fra børnenes side. Begge dele hører med til kongens embede. Han skal drage omsorg for sit folk (se SI 72, hvor kongens pligter omfatter de sociale forhold i landet, de udenrigspolitiske, hvor han skal sikre sejr og fred, og som det tredje også frugtbarheden i landet). Fadermetaforen bruges i Det Gamle Testamente af og til om Gud selv ( se fx SI 89,27; 103,13), ligesom talen om kongen som søn forudsctter, 
at Gud er som en far i forhold til kongen. Fadernavnet er således også med til at understrege kongens ncere forbindelse til Gud.

I SI 72,5 udtrykkes ønsket om, at kongen må leve "så lœnge solen og månen er til, slœgt efter slœgt." Og lœengere nede i samme salme hedder det: "Gid hans navn må leve for evigt, så lœnge solen er til, skal hans navn vokse.", SI 72,17. Der er ikke tale om evigt liv i betydningen et uendeligt liv, men et meget langt liv. Når det er en konge af Davids slœgt, der omtales, kan der også tcenkes på, at hans slœgt må herske i uendelig lang tid, 2 Sam 7,13.16.

Endelig kaldes den kommende konge for Freds Fyrste, שר-שלום. Det hebraiske ord for fred, שלום, har en langt bredere betydning end det danske ord fred, som normalt blot angiver fravœr af krig. שלום indebcrer naturligvis, at man ikke er under fremmedherredømme (jf. v. 3-4), men derudover har det også et positivt indhold. Det indbefatter alt det, som en konge skal sikre for sit land: lykke og stabilitet både i undersåtternes indbyrdes liv og i forhold til omgivelserne, fremmede folk såvel som naturen, SI 72. Fred og retfcrdighed hører således sammen (se SI 89,15, hvor retfcerdighed og ret er grundvolden for kongens trone). Når man hilser et andet menneske med en fredshilsen, indebœrer det netop ønsket om et lykkeligt liv på alle måder, fx Gen 29,6.

Glosen שר er betegnelsen for en fyrste, men bruges her om kongen. Om Gud selv bruges glosen i Dan 8,25, hvor Jahve betegnes som fyrsternes fyrste.

De fire tronnavne er alle med til at understrege, at den nyfødte er en kronprins, som der må stilles ganske scerlige forventninger til. Dette uddybes i v. 6, hvor hans herredømme beskrives som stort (se ovenfor om tekstrettelsen) og freden som uendelig (jf. tronnavnet Evigheds Fader). Riget er nœrmere bestemt som Davids rige. Alle løfterne til kong David om et fortsat dynasti gœelder derfor også for denne kongesøn. Hans trone, dvs. hans magt og styre, skal bygge på ret og retfcerdighed. De to gloser, צדקה og משפט, betegner ikke alene retfcerdighed i juridisk forstand. De betegner også, at der er orden i riget og dermed sikkerhed. Ret og retfcerdighed har som forudscetning, at verden som sådan er et ordnet kosmos, som Gud har skabt efter sin plan. Og når retfcerdigheden råder, så kan mennesker leve et godt liv og udfolde sig.

er afledt af verbet at dømme, שפטפט. Det betyder at skaffe nogen deres ret og dermed holde retten i hœvd eller at fastholde hœvdvunden skik. צרקה er retfœrdighed som norm for det korrekte. At handle med retfœerdighed kan derfor betyde, at man handler i overensstemmelse med Guds bud eller blot i lydighed mod Gud (jf. Gen 15,6). Gud handler derfor selv med retfœerdighed, når han scetter sin vilje igennem og griber ind og hjœelper de svage mod overmagten. Derfor kan ret- 
fœrdighed og frelse også anvendes parallelt om Guds handlen, Jes 45,21. Guds retfœrdighed er ikke blot en egenskab ved Gud, men en handlemåde. Når kongens trone skal bygges på ret og retfœerdighed betegner det derfor den måde, hvorpå han skal styre sit land.

Endelig understreges varigheden af dette styre endnu engang: fra nu af og til evig tid, dvs. så lœenge man overhovedet kan forestille sig (se ncermere om denne ideelle konge s. 79).

Alt dette kan siges om den kommende konge; men det er Jahve selv, der udvirker det takket vœre sin lidenskabelige forkcrlighed, nidkœrhed, for den davidiske konge. Glosen pruges om Gud i forbindelse med hans iver efter at frelse sit folk, fx Jes 37,32, og om profeternes nidkœrhed over for Jahve, fx 1 Kong 19,10.14. I forholdet til andre guder kan Jahve også betegnes som nidkcr, lidenskabelig, men da er betydningen tat på den lidenskabelige jalousi, der kan gribe den forsmåede bejler, Ex 20,5 og Ex 34,14.

Med v. 6 afrundes det store afsnit, som kaldes Denkschrift (se ovenfor s. 99-101 om mulige afgrœensninger af Denkschrift), og temaet om Jahves vrede, der blev påbegyndt i Jes 5,25-30, genoptages og føres videre i afsnittet Jes 9,7-10,4, som slutter med omkvœdet: "Trods det har hans vrede ikke lagt sig, hans hånd er stadig løftet.", (se også Jes 5,25; 9,1 1.16.20).

Tilbage til indholdsfortegnelsen

\section{Jes 9,7-20}

\section{Tekstkritik}

$10 a-a$

MT betyder "Da œggede Jahve Resins fjender". Rent sprogligt er det fuldt forståeligt. Indholdsmœssigt giver det dog ikke mening, at det er Resins fjender, Jahve œegger mod det: עליו, dvs. mod Jahves folk. DO 1992 har derfor valgt at tolke teksten sådan, at det er en skriver, der har tilføjet Resin ude i margen for at angive, hvem der er tcenkt på med fjenderne. Senere er Resin så kommet ind i selve teksten og er fejlagtigt blevet forbundet med ordet fjender. Under alle omstcendigheder virker Resin overflødigt, da fjenderne identificeres i v. 11 som aramceerne og filistrene. Enten må man helt slette Resin, hvad nogle forskere foreslår, eller netop betragte det som et senere indskud, hvad DO 1992 gør. 
$19 c$

MT betyder, at de spiser hans arms kød: בשר־זרעו. DO 1992 retter teksten ved at fjerne et enkelt bogstav, så der i stedet står: בשר־רעו, hans landsmands kød. Teksten er dog fuldt ud forståelig, og meningen bliver ikke meget anderledes, hvis man retter som foreslået. Teksten kan derfor godt bevares, selv om udtrykket er uscedvanligt.

\section{Karakteristik}

Med Jes 9,7-20 fortsœetter rœkken af udsagn om Jahves vrede, som omkranser Jesajas Denkschrift. Jes 9,7-20 er formet som et tilbageblik på en rakke politiske begivenheder, som her tolkes som udtryk for Jahves vrede mod sit folk (se som parallel hertil Am 4). Forskerne har diskuteret, om Jakob og Israel betegner Nordriget alene eller såvel Nordriget som Juda. Den parallelle omtale af Efraim og Samaria i v. 8 peger dog på, at det er Nordriget, ordene er henvendt til. Først med v. 20 nœvnes Juda. Til trods for at Jahve havde talt til dem, og her må der ud fra den littercere sammenhœeng tcenkes på de trusler og advarsler, som findes i kapitlerne forud for Denkschrift, viste de sig hovmodige (jf. hovmodsmotivet i Jes 2,6-22) i deres urimelige optimisme og tiltro til egne muligheder. På den baggrund straffede Jahve dem ved at sende fjender mod dem i form af nabofolkene, aramœerne og filistrene. Denne første straffeekspedition fik dog ikke befolkningen i Nordriget til at vende om til Jahve. Nœste afstraffelse bestod i, at samfundet gik i opløsning indefra. Jahve fjernede de ledende og de, som skulle vejlede blev vildledere (jf. Jes 3,1-9). Endnu en tredje straffeekspedition satte Jahve i vark. Uretten bredte sig som ild i skoven og medførte det totale sammenbrud, hvor indbyggerne endog kaster sig over hinanden, og det eneste, de kan enes om, er i fœllesskab at overfalde Juda. Og alligevel har Jahves vrede ikke lagt sig. Tilbageblikket på Jahves straf og understregningen af den umådelige og vedvarende vrede skaber ikke forventninger om, at vreden nogensinde vil standse.

Gammeltestamentleren Hans Wildberger har forsøgt at rekonstruere en oprindelig rœkkefølge af disse vredesudsagn ud fra den historiske udvikling af Israels historie (jf. Hans Wildberger 1972 til de pågœldende tekster). Efter hans mening skulle det œldste og dermed første udsagn vœre Jes 9,7-1 1*. Her handler det om krigene med aramaeerne og filistrene, der går tilbage til 9. årh. f.Kr., men fortscetter ned i 8. årh. f.Kr. Derpå følger Jes 9,12-16*, som Wildberger tolker som en beskrivelse af begivenhederne under Jehus revolution omkring 845 f.Kr. Det tredje eksempel på Jahves vrede findes i Jes 9,17-20, hvor vreden viser sig i form af borgerkrig, men hvor de to nordlige stam- 
mer, Efraim og Manasse trods alt slår sig sammen i et angreb på Juda. Dette peger på tiden ned mod den syrisk-efraimitiske krig i 734-732 f.Kr. Herefter placerer Wildberger Jes 5,25. Ikke fordi han kan datere det som endnu yngre, men fordi dets skildring af Jahves vrede er endnu voldsommere end de foregående udsagn. Og endelig betragter han Jes 5,26-30 som det sidste eksempel på Jahves vrede, som da tolkes om assyrernes angreb.

Det er ikke muligt at afgøre, om en sådan rekonstruktion er korrekt. Som nœevnt er beskrivelsen af hœren i Jes 5,25-30 åben for fortolkning, ligesom skildringen af det interne sammenbrud i Jes 9,12-16 ikke nødvendigvis handler om Jehus revolution, men kan tolkes om andre politiske kriser i Nordriget. Det samme gœelder borgerkrigsskildringen i Jes 9,17-19, mens kun v. 20 mere prœcist peger på modscetningerne mellem Nordriget og Juda. Men også her er der flere situationer, der kan komme på tale ud over tiden lige før den syrisk-efraimitiske krig. Forholdet mellem de to riger beskrives i Kongebøgerne netop ikke som fredfyldt, men fuldt af konflikter, fx 1 Kong 15,32.

I stedet for at forsøge at rekonstruere en historisk rœkkefølge er det nok vigtigere at slå fast, at de enkelte vredesudsagn er forbundet med begivenheder, som datiden havde kendskab til. Udsagnene har derfor virket trovardige. Man har dengang kunne forstå ordene ud fra, hvad man havde fået fortalt om fortiden, og muligvis i begyndelsen også ud fra egne erfaringer. Jahves trusler var ikke forblevet ved truslerne, han greb ind i historien og straffede sit folk for dets frafald. Selve budskabet og tilliden til, at det er Jahve, der griber ind i folkets historie er det afgørende, ikke om vi i dag kan rekonstruere en passende historisk baggrund eller ej.

Når vi lœser udsagnene i den nu foreliggende kontekst, er der desuden grund til at lœgge mcerke til den retoriske effekt, som redaktorerne har villet skabe gennem placeringen af oraklerne. Ved at placere disse vredesudsagn rundt om Denkschrift har de kunnet vise, at det frelsesbudskab, som Jesaja var sendt med, ikke cendrede på Jahves vrede, for frelsesbudskabet blev mødt med afvisning. Vreden er derfor velbegrundet. Ja, ikke blot fordi Judas konge i forbindelse med den syriskefraimitiske krig har stolet mere på sig selv og assyrerkongen, men fordi folket langt, langt tilbage i historien har handlet lige sådan. De har afvist Jahve, selv om han har forsøgt at bringe dem tilbage til sig ved hjœlp af sine afstraffelser. De har ganske enkelt ikke lœert af deres egen historie.

Ved at placere det lange tilbageblik på de tidligere katastrofer, Jes 9,7-20, efter Denkschrift gøres det helt klart, at en ny katastrofe var uundgåelig. Samarias undergang i 722 f.Kr. var en sådan katastrofe, 2 Kong 17,3-6 og 18,9-12. Den omtales ikke her i Jes 9 (se veråbet over Samaria i Jes 28), men begivenheden må have gjort et kolossalt indtryk i Juda. Nu havde de set, hvordan det kunne 
gå, og selv var de kun med nød og nceppe undsluppet ved at betale tribut til assyrerkongen, 2 Kong 16,7-9. Men lœst på et langt senere tidspunkt, hvor Jerusalems ødelœggelse var en realitet, dvs. efter 587 f.Kr., kan disse kapitler om Jahves vrede stadig fungere som begrundelse for, at frafald medfører Guds vrede, og at konsekvenserne deraf viser sig i folkets historie.

\section{Struktur}

7-11 Udsagn om Israels hovmod og Jahves straf i form af angreb fra aramcerne og filistrene afrundet med omkvœd om Jahves vrede og Jahves stadige trussel mod folket.

12-16 Udsagn om folkets manglende omvendelse, der medfører, at Jahve fjerner deres ledere afrundet med omkvœd om Jahves vrede og Jahves stadige trussel mod folket.

17-20 Udsagn om folkets uretfœrdige handlinger, der straffes med borgerkrig og total opløsning af samfundet afrundet med omkvœd om Jahves vrede og Jahves stadige trussel mod folket.

\section{Fortolkning}

\section{7-11}

Det første afsnit indledes med en henvisning til, at Jahve har sendt et ord mod Jakob, som desuden kaldes Israel. Begge navne kan bruges som betegnelse for Jahves folk, idet Jakob med tilnavnet Israel er stamfaderen til alle 12 stammer. Ud fra konteksten må man så afgøre, om der tcenkes på et af de to riger eller dem begge tilsammen. Den ncermere bestemmelse i v. 8 viser, at det her mere prœeist gœlder Nordriget, der omtales som Efraim. Hovedstaden i Nordriget er Samaria, som lå i Manasse stamme (jf. de to Josefsønner, som i stedet for deres far blev regnet som stamfœdre). Formålet med denne indledning er at dokumentere, at Jahve på forhånd havde advaret dem om den straf, der truer. De kan altså ikke dcekke sig ind under, at de ikke vidste, hvad Jahve ville. At Jahves ord har vœret en advarsel om en kommende straf fremgår indirekte af indbyggernes reaktion. De betragter den kommende ødelœggelse, billedligt udtrykt gennem ødelœeggelse af teglsten og af morbcrtrceer, som en god anledning til at bygge med bedre materialer, sten, og til at plante trceer, som er bedre byggemateriale, nemlig cedrene (jf. at Salomo anskaffede cedertrce til bygningen af sit kongepalads og templet, 1 Kong 5-7; se også om Davids cedertrcshus i 2 Sam 7,2). Fra at bo i dårlige hytter forventer de at kunne komme til at bo i fine huse. Ved hjcelp af citatet underbygges anklagen for hovmod, et stilistisk trœk, som vi møder flere gange (se Jes 10,8-1 1.13-14; 28,9-11.15). 
Denne reaktion opfattes som udtryk for hovmod og fremkalder Jahves vrede. Aramcerne og filistrene beskrives i Det Gamle Testamente som stadigt tilbagevendende fjender. I såvel 9. som 8. årh. f.Kr. kœmpede Israel mod aramceerne (se nœrmere i fx 1 Kong 20; 22 samt Jes 7,1-9). Krigene med filistrene forbindes traditionelt med kongerne Saul og David (se fx 1 Sam 4-7; 13 og 17 samt 2 Sam 5,17-25), men også på senere tidspunkter opstår der stridigheder (se Am 1,6-8 om filisterbyernes forbrydelser). Med til traditionerne om fortiden hører netop kampene med disse to folkeslag, og vel at mœrke som eksempler på, hvordan Jahve straffer sit eget folk ved hjœelp af fjenderne. Beskrivelsen af det åbne gab, בכל־פה, angiver det rovgriske hos fjenderne. De er som vilde dyr (jf. SI 22, 14). Afsnittet slutter med omkvcedet om vreden og den løftede hånd (se ncermere til Jes 5,25).

\section{2-16}

Det følgende udsagn indledes med begrundelsen for den fortsatte vrede. På trods af straffen har folket endnu ikke vendt sig til Jahve. Tanken bagved svarer til Jes 1,4-9, hvor folket stilles over for det retoriske spørgsmål: "Hvor vil I have flere slag, siden I fortscetter frafaldet?", Jes 1,5. Afstraffelsen har som formål at få folket til at komme på bedre tanker. Men dette "pœdagogiske" middel ser ikke ud til at virke. De søger stadig ikke Hœrskarers Jahve, som her netop omtales som den magtfulde Jahve. Verbet søge, דרש, bruges dels om at komme til Jahve for at få et svar fra ham i en krisesituation (se fx 1 Kong 22,5, hvor kongen gennem profeterne søger råd hos Jahve om krigens udfald, eller tilsvarende i Jer 37,7$)$ dels mere generelt om at vende sig til Jahve og scette sin lid til ham.

Mens den hårde straf ifølge Jes 9,12 ikke får folket til at søge Herren, går det helt anderledes i Hos 6,1. Her beslutter folket som reaktion på, at Jahve har kastet sig over dem som et vildt dyr, at vende om: "Lad os vende om til Herren; han har sønderrevet, men han vil helbrede os, han har slået, men han vil lage os." Opfattelsen af Jahve som den, der både slår og helbreder, er central for Det Gamle Testamente. Når der kun er én Gud, må man forbinde ham såvel med de hårde slag som med helbredelsen. Netop derfor må forhcerdelsen bestå i, at de ikke skal "vende om, så han må helbrede dem", Jes 6,10. Omkvœdet om Jahves fortsatte vrede er derfor med til at pege på forhœrdelsen som en realitet.

Med brug af forskellige billeder beskrives det herefter, hvordan Jahve huggede hoved og hale af Israel. Når hoved og hale er borte, er der ikke meget tilbage at gøre godt med (jf. Jes 19,15). Det parallelle udtryk, som er hentet fra planteverdenen, skal tolkes på samme måde. Der er stort set intet tilbage af planten. Billedet udlcegges i de følgende vers. Hovedet er de celdste, dvs. dem, der 
har autoritet i samfundet, og dem, der nyder respekt. Halen er løgneprofeterne. En løgneprofet er en, der forkynder sine egne tanker i stedet for Jahves. I Jer 23,16-18 advarer Jeremias mod de profeter, der ikke har lyttet til Jahve. De har, billedligt udtrykt, ikke vœret til stede i Jahves rådsforsamling, men finder selv på, hvad de vil forkynde.

Videre anklages folkets vejledere for at gøre prœcis det modsatte af, hvad de burde, v. 15. De burde pege på den rigtige vej, dvs. den der fører til Jahve. Vejen er ofte billede på selve livet, og vildledningen betyder derfor, at de får folket til at føre et forkert liv (se også SI 119,29-32). Alting er blevet vendt om, derfor kan Jahve heller ikke glcede sig over det, der tidligere var anledning til glœde. De unge maend betragtes positivt, når man ser dem som samfundets fremtid. Det er også dem, der i krigen skal forsvare landet. Også enken og den faderløse ncevnes. Jahve er under normale omstœndigheder i scrlig grad opmœrksom på de svage i samfundet (jf. formaningerne i Jes 1,17 til at skaffe den faderløse og enken ret samt Jes 10,2), men ikke i den aktuelle situation. Verbet for at vise barmhjertighed, רחם, er afledt af en rod, der også anvendes om livmoderen, Jer 1,5, og billedligt kan bruges om at nœre kœrlighed og omsorg, fx Es 63,15; SI 51,3; 103,13. Hvad vi primcrt forbinder med kvindelige egenskaber, anvendes i Det Gamle Testamente billedligt om Jahve (se også Jes 49,15, hvor Jahve sammenlignes med en ung mor).

Situationen er totalt forandret, når enker og faderløse nu stemples som gudløse forbrydere. At vœre חנק betyder at vœre uden Gud, Jes 10,6; 33,14, men kan også bruges om, at jorden bliver vanhelliget og ramt af forbandelse. Alt hvad der hører den normale velsignede tilstand til forsvinder, Jes 24,5-13. At vœre gudløs får konsekvenser for de gudløses egen skcbne, men viser sig også i deres handlinger. Alle sammen øver de ondt, מרע, og de taler נבלה. Roden נבל bruges om tåbelighed, men den tåbelighed, der viser sig i, at man afviser Gud og derfor handler, som om Gud ikke eksisterer og krœver noget, Jes 32,6 (se også Dom 19,24).

Vers 16 rundes af med omkvœdet: Jahves vrede har stadig ikke lagt sig. Underforstået er da, at straffen endnu ikke har fået folket til at søge Jahve.

Forskerne har naturligvis drøftet, hvilken historisk begivenhed, der kan vœre tœnkt på i forbindelse med decimeringen af folket. Der er tale om et tilbageblik på Nordrigets historie, hvor der ved flere lejligheder er sket voldsomme omvaltninger. En mulighed, som flere forskere har peget på, er Jehus revolution, som omtales i 2 Kong 9, en begivenhed, som også ncevnes i Hos 1,4. Men, som ncevnt ovenfor, er der ikke tilstrckkeligt prœcise angivelser i teksten til entydigt at udpege den 
situation, der oprindelig er tcenkt på. Efter 722 f.Kr. vil man naturligvis forbinde udsagn som dette med Nordrigets fald og se ødelaggelsen af Samaria som opfyldelse af oraklet.

\section{$17-20$}

I dette afsnit føres tanken om ondskabens ødelœeggende kraft videre. Billedet af den fortcrende ild bruges her til at vise, hvor hurtigt og voldsomt urettens konsekvenser viser sig. Ligesom ilden fortcerer alt, hvad den kommer i nœrheden af, således inficerer ondskaben alt. Billedet er hentet fra naturens verden. Tjørn og tidsel angiver sammen med skovens taette krat al vegetation, såvel den vardiløse som den kostbare. Katastrofen er altomfattende, når ondskaben breder sig som en skovbrand. Et tilsvarende billede bruges i Jes 10,17-19, hvor det er Jahve selv, der bliver til en fortcrende flamme, som fortcrer tjørn og tidsel og hele den herlige skov (se også Jes 5,6, og 7,24, hvor tjørn og tidsel bruges om det udyrkede land). Paralleliteten mellem billedet af sivet, der mister både top og stcengel, og tjørn, tidsel og skov, der brœnder op i ilden, gør det ncerliggende at overveje, om også dette sidste billede skal tolkes om samfundets ledere og dem, der hører til i bunden af samfundet (jf. at trcet bruges som billede på forskellige personer i fx Jes 1,29-31; 6,13; 10,33-11,1).

Tilbage bliver blot røgen, der stiger op. Glosen for denne opstigen er גאות, der også bruges i Jes 28,1.3, men i betydningen stolthed, den stolte krone. I Jes 2,12 er Jahves dag ligeledes vendt mod alt stolt, גאה, mens en anden form, גואן, i Jes 2,10.19.21 betegner Jahves storhed, dvs. den sande storhed. Billedet af røgen skal vise, hvad der bliver tilbage af al deres stolthed: Den blœser vœk i vinden.

Mens v. 17 kunne give indtryk af, at den menneskelige ondskab er alene om at scette ødelœggelsen i vœrk, uddyber v. 18 beskrivelsen ved at kombinere billedet af ilden med Jahves vrede. At Jahve forbindes med ild er der mange eksempler på i Det Gamle Testamente. Det forekommer hyppigt i teofaniskildringer, hvor et af de fœnomener, der følger af, at Jahve viser sig, er ild, fx SI 97,3-5. At Jahves ild og Jahves dom kombineres, kendes fra Am 7,4-6, hvor Jahve kalder på ilden til dom, samt fra Dan 7,9-10, hvor den gamle af dage sidder på en trone af ild. Tanken om ilden og dommedag er også kendt i Det Nye Testamente, hvor det i 2 Pet 3,12-13 hedder, at når Guds dag kommer, da skal himlene "gå op i luer og elementerne komme i brand og smelte" (se også Åb 20,10.14-15 om ildsøen).

Undertiden forbindes ilden meget tcet med vreden, som når Jahve i SI 18,8-9 bliver så vred, at røgen står ud af nœesen, og "fortœrende ild af hans mund, gløder flammede op fra ham". Glosen 
for vrede er i Jes 9,18 עברה, der i Jes 13,9 indgår i formuleringen עברה וחרון אף, som i DO 1992 er gengivet ved harme og flammende vrede.

Ilden rammer både landet og befolkningen, som fortceres af ilden. Hvordan denne altfortcerende skovbrand skal vise sig fremgår af udlœgningen i slutningen af v. 18 og i v. 19: Borgerkrigens rœdsler, hvor alle kaster sig over alle. Verbet חמל betyder at have medlidenhed med og derfor skåne, fx Deut 13,9; Jer 13,14; Ordspr 6,34. Hvad der under normale forhold burde kendetegne forholdet til landsmanden, her omtalt som ens bror, אחיו, er nu ophcevet. Samfundet er i total opløsning, og situationen beskrives som en umœttelig sult, hvor man œder løs af hinanden uden at blive mat. I to parallelle udtryk understreges det resultatløse i volden. De forbliver lige sultne, ja de kan slet ikke tilfredsstilles. At de spiser kødet af hinanden (jf. tekstkritikken til dette vers ovenfor) kan enten forstås bogstaveligt eller billedligt. Fortscettelsen i v. 20, der handler om krigeriske overfald, tyder dog på, at det er billedsprog (se også Mi 3,3). Men når kanibalismen bruges som billede, bliver det klart, at nu overskrides endog et af de stœrkeste tabuer. Stammerne, der skulle vœre som brødre, fœlles som de er om stamfaderen Jakob, ligger nu i krig med hinanden. I Nordriget kœemper de to centrale stammer, Josefsønnerne Efraim og Manasse, men hinanden. Kun ét kan de enes om, nemlig at bekrige Juda.

Hvad det er for en indbyrdes magtkamp i Nordriget, der er tcenkt på, kan ikke afgøres endeligt. En mulighed er Pekas oprør mod Pekaja, 2 Kong 15,25. Det fœelles overfald på Juda må, i den nuvœrende kontekst, vœre en henvisning til den syrisk-efraimitiske krig, hvor Nordriget sammen med Syrien belejrer Jerusalem, Jes 7,1-9 samt 2 Kong 15,37. Også tidligere i historien har der dog ifølge Det Gamle Testamente fundet kampe sted mellem Nordriget og Juda (se fx 2 Kong 14,8-14). Igen må vi konstatere, at vi har en meget begranset viden om de historiske forhold dengang, men at det ikke hindrer os i at forstå budskabet i dets littercere kontekst.

Også dette historiske tilbageblik har som funktion at vise, at Jahves vrede mod sit eget folk er velbegrundet. De har ikke villet tage ved lcere af de ulykker, der har ramt dem, og er derfor ikke vendt om til deres Gud. Derfor afrundes afsnittet med omkvaedet om den handlekraftige Jahves fortsatte vrede.

Tilbage til indholdsfortegnelsen 


\section{Jes 10,1-32}

\section{Tekstkritik}

Der er ingen grund til at rette i teksten.

\section{Karakteristik}

I afsnittet Jes 10,1-4 knyttes to typer af udsagn sammen, veråbet og vredesudsagnene. Afsnittet fungerer dermed både som en videreførelse af de seks veråb, der findes før Denkschrift, Jes 5,8-24, og som en fortscettelse af vredesudsagnene, hvoraf det første er placeret før Denkschrift, Jes 5,25, og de følgende tre i 9,7-20. Når de to udtryksformer forbindes i Jes 10,1-4, bliver det tydeligt, at Jahve ikke blot har udråbt dødsklagens ve over sit ulydige folk, men også har vist sig i stand til at realisere de trusler, der kom til udtryk i veråbene. Slagene er haglet ned over dem, men det har ikke hjulpet. Sammenfattende må man sige, at veråbene og vredesudsagnet forud for Denkschrift legitimerer Jahves beslutning om at forhœrde folket, mens vredesudsagnene og veråbet, der står efter Denkschrift, viser konsekvenserne af forhœrdelsen.

Det sidste veråb er vendt mod lovgiverne, der udsteder uretfœrdige love, som går ud over de svage i samfundet (jf. kritikken i Jes 1,17 samt 3,13-15). Også de vil blive ramt af Jahves straf uden mulighed for at flygte. Og igen vil straffen tage form af nederlag i krigen. Den manglende etik vil få voldsomme konsekvenser. Men heller ikke det er nok til at slukke Jahves vrede.

Jes 10,1-4 skal løeses i sammenhœng med de tidligere veråb, men fungerer desuden som overgang til kapitlets nœste veråb, Jes 10,5-11. Dette afviger fra de tidligere veråb ved at vœre vendt mod folkets fjende, assyrerkongen. Men begrundelsen svarer til den jesajanske forkyndelse i $\varnothing v r i g t$. Det er kongens hovmod, der fører til, at Jahve vil straffe ham. Hovmodet gøres synligt gennem citater af, hvad assyrerkongen har sagt om sin egen magt. Dermed afslører han, at han ikke har forstået, at han er Jahves redskab. Jes 10,12-15 fortscetter med trusler mod assyrerkongen og gengivelse af hans hovmodige og selvovervurderende ord. Straffen formuleres billedligt i v. 16-19 som en ildebrand, der er antœendt af Jahve selv. Den begynder i assyrerkongens egen krop, men breder sig til hele hans land. Straffen over assyrerkongen får også konsekvenser for Israels rest, Jes 10,20-27, der skal vende om til Jahve. Assyrerkongens magt er kortvarig, derfor skal de ikke lcengere frygte ham. Assyrerkongens kommende fald hindrer dog ikke, at han og hans hœr skal drage ned mod Jerusalem og true byen med ødelœggelse, Jes 10,28-32. 
Kapitel 10 består af en rœkke enkeltafsnit, der først redaktionelt er blevet føjet sammen til et samlet forløb. Det har vcret vigtigt for redaktionen at få vist, at assyrerkongen ikke handler på egen hånd, men er Jahves redskab. Og netop som redskab er han underlagt Jahves planer, som nok indbefatter en alvorlig afstraffelse af såvel Nordriget som Juda, men ikke den totale tilintetgørelse. En rest skal vende om til Jahve og overleve. Ganske som folket var hovmodigt, har også assyrerkongen vist sig hovmodig. Der skabes derved en form for parallelfortcelling, hvoraf det fremgår, at hverken Jahves eget folk eller hans redskab assyrerkongen har forstået, at deres forhold afgøres af, hvordan de forholder sig til Jahve. Det er Jahve, der bestemmer historiens gang, ikke jordiske magter.

\section{Struktur}

1-4 Veråb mod de uretfœrdige lovgivere afrundet med omkvœd om Jahves vrede og Jahves stadige trussel mod folket.

5-11 Veråb over den hovmodige assyrerkonge begrundet med hans egne udsagn.

12-15 Trussel om straf over assyrerkongen begrundet med hans egne udsagn.

16-19 Trussel om straf over assyrerkongen og hans land.

20-27 Løfte om at Israels rest skal overleve og Assyrien om kort tid tilintetgøres.

28-32 Skildring af assyrernes march frem mod Jerusalem.

\section{Fortolkning}

$1-4$

Veråbet er begrundet med lovgivernes magtmisbrug. Lovgiverne er kongelige embedsmand, og de love, de udsteder, betegnes som onde. Glosen און kan dcekke over mange forskellige former for ondt: undertrykkelse, SI 10,7, eller løgn (jf. SI 36,4, hvor און, står parallelt med svig, מרמה) eller noget vardiløst, Jes 41,29. I Jes 1,13 bruges און ligeledes som en samlebetegnelse for alt det onde, de gør, og som er mod Jahves vilje. I paralleludsagnet understreges det, at deres anordninger er uretfœrdige. Glosen עמל bruges også til at betegne vold og bedrag, således som det fremgår af det følgende. Uretten viser sig i, at de bruger lovene til at undertrykke de svage. Landets love skulle skabe sikkerhed for, at de dårligst stillede fik en fair behandling (jf. idealet af retfœerdigt styre i Jes 1 1,4), men lovgiverne laver love, der kan bruges til at afvise samfundets svageste, når de vil have deres sag for retten. Som eksempler nœvnes de to grupper, som netop er uden anden form for støtte i tilvcrelsen, enken, som ikke har en œgtemand til at forsvare sig, og den faderløse, som mangler en far til at tage 
sig af at sikre ejendomsretten (jf. Jes 1,17 samt veråbet over dem, der samler jord og ejendom i Jes $5,8)$.

I et retorisk spørgsmål konfronteres lovgiverne i v. 3 med den straffens dag, som vil ramme dem, og som de ikke vil kunne undslippe. Udtrykket יום פקדה må betegne den straffedag, som i Jes 2,12 er omtalt som יום ליהוה צבאות, Hcrskarers Jahves Dag. Der findes lignende udtryk i Jeremiasbogen, hvor פקדה forbindes både med glosen tid, fx Jer 8,12; Jer 10,15, og med glosen år, fx Jer 11,23; Jer 23,12, mens Hos 9,7 ncevner straffens dage ימי הפקדה. Det fœlles for disse forskellige udtryk er forventningen om, at Jahve på et tidspunkt vil komme og udføre sin straf. Nogen bestemt dag er der ikke tœenkt på. Hvordan straffen vil forme sig, kan man få et indtryk af gennem billedbrugen i v. 3. Uvejret fra det fjerne er i Ez 38,9 billede på den enorme hœr, som storfyrsten Gog skal mønstre mod Israel: "Du skal trcekke op som et uvejr og komme og dcekke landet som en sky, du og alle dine tropper og de mange folkeslag sammen med dig." Lœest i Jesajasammenhaengen, hvor kapitlet også indeholder en skildring af assyrernes fremmarch mod Jerusalem, er det naturligt også her at forstå uvejret om en fjendtlig hœr (se også beskrivelsen i Jes 13,5 af folket fra det fjerne, der er Jahves vredes redskab). Og da disse fjendtlige hœre kommer som Jahves redskaber, er der ingen, de kan søge hjœelp hos. Den eneste virkelige hjœelper ville vœere Jahve (jf. brugen af עזר i SI 121,1 om Jahve), men han vil netop ikke gribe ind. Alt hvad de har samlet af rigdomme skal gå tabt. Der er ingen steder, hvor de kan gemme dem. Glosen כבודכם kan ikke blot betyde deres rigdom, men også deres œre.

I v. 4 bliver det endnu tydeligere, at der tankes på en krigssituation, da straffen vil resultere i, at de enten bliver taget til fange eller bliver drcbt. Ikke desto mindre har Jahves vrede stadig ikke lagt sig. For sidste gang rundes der af med dette omkvaed.

\section{5-11}

I veråbet over Assyrien, som i realiteten er henvendt til landets konge, er det en hovedpointe, at assyrerkongen er Jahves redskab. Det er ikke af egen magt, han har kunnet foretage sine erobringstogter, men fordi Jahve har villet det. Billedlig talt er assyrerkongen som en kœp, der styres af Jahves vrede (til glosen vrede, אף, se Jes 9,18). Glosen שבט bruges om den stok, hyrden er udstyret med, så han kan forsvare sin hjord, SI 23,4. Den bruges desuden om den kongelige herskerstav, scepteret, Gen 49,10. I Jes 9,3 er det slavefogeden, der er udstyret med en kœp til at slå med, mens det er den kommende konge, der i Jes 1 1,4 slår sine modstanderne med sin munds stok (se også Jes 14,5). Der er tydeligvis tale om et magtmiddel, og det kan som sådan vare et symbol på herskermagten. Når 
assyrerkongen er Jahves kœp, er han underlagt Jahves herskervilje. Da det er Jahves vrede, der styrer kœppen, er den også med til at bestemme, hvem kœppen skal ramme.

Glosen מטה bruges om den stok, en mand har med sig på vandring, fx Gen 38,18, men også som symbol på kongens herskermagt, SI 1 10,2, Jer 48,17. Her i Jes 10,5 er selve Jahves vrede beskrevet som en stok i hånden på assyrerkongen. Det er ikke ham selv, der handler, men Jahve. Med endnu en glose, זעם, angives den vrede, der ligger bag Jahves handlinger og fører til hans straf. (jf. Jer $15,17)$.

Målet for kœppen og stokken er et gudløst folk, som Jahves vrede er rettet imod, v. 6. Til glosen חנק, gudløs, se ovenfor i Jes 9,16. Med en tredje glose forbindes vreden endnu tcettere med dette folk, som nu karakteriseres som עם עברתי, min vredes folk. At midlet er et krigerisk angreb fremgår af de følgende linjer. Assyrerne skal på Jahves befaling tage bytte og plyndre, ja de skal nedtrampe folket, som var de blot ler på gaden. Ved hjcelp af ordspil, לשלל שלל, og לבו בז kommer befalingen til at stå meget markant. Samtidig er der en klar henvisning til Jes 8, 1, hvor Jesaja fik befaling om at skrive på tavlen. Både verbet for at plyndre og verbet for at røve bytte går igen de to steder. Og begge steder er det assyrerkongen, der tcenkes på. Assyrernes hœrgen skildres til slut i verset med billedet af en flok dyr, der kommer ind over et område og tramper alt ned (jf. vingårdens skcebne i Jes 5,5).

Over for Jahves vilje og befaling scttes i v. 7 assyrerkongens planer. Det foranstillede והוא, men han, markerer modsctningen mellem Jahve og assyrerkongen. Hjertet, לבב, er i gammeltestamentlig tankegang stedet for viljen. DO 1992 udelader ordet hjerte i gengivelsen, for at undgå den misforståelse, at der er tale om en følelsesmcessig reaktion fra assyrerkongens side. Det, der fylder assyrerkongens hjerte, er ikke at vœere redskab for Jahve, men selve ødelceggelsen og udryddelsen af mange folk. Han er optaget af sine egne stormagtsambitioner.

At kongen dermed gør sig skyldig i hovmod underbygges i v. 8 gennem et direkte citat, indledt med "for han sagde". At konger har berømmet sig selv og dermed underbygget deres egen magt er velkendt fra Den Ncre Orient (jf. fx Sankeribs beskrivelse af sine erobringstogter s. 46-47). Citatet består af en rœkke retoriske spørgsmål, som skal besvares med et ja. Det første angår de fyrster, der er underlagt assyrerkongen, og som ikke blot er småfyrster, men konger. Hermed understreger assyrerkongen først og fremmest sin egen position som storkonge.

I de følgende vers, v. 8-11, fortsctter selvpromoveringen i form af en gennemgang af de hidtidige erobringer, som skulle vœre tilstrœkkelige til at vise, at han også vil vœre i stand til at erob- 
re Jerusalem. Argumentationen består af en rakke påstande om de byer, assyrerkongen hidtil har erobret. Rœkkefølgen, som kommer klarest frem i den hebraiske tekst, er geografisk bestemt. Den rute, hceren følger, svarer til bevœgelsen fra nord mod syd. Hermed fastholdes også den mytiske forestilling om den store fjende, som kommer fra nord, Jer 1,13-14; Jer 6,22-23; Zak 2,10. De erobrede byer er: Karkemish, Kalno, Arpad, Hamat, Damaskus og Samaria. Nœeste station på ruten udpeges som Jerusalem. Karkemish, som ligger ved Eufrat, blev erobret af assyrerkongen Sargon II i 717 f.Kr., mens Kalno må vœre en by på vej mod Arpad, formentlig i Nordsyrien (jf. Am 6,2 og Gen 10,10, hvor byen kaldes Kalne). Den blev allerede i 738 f.Kr. erobret af Tiglat-Pileser III, men formentlig igen i forbindelse med erobringen af Karkemish. Arpad ligger nord for det nuvcerende Aleppo og faldt ligeledes for Tiglat-Pileser III i 740 f.Kr. Hamat er en storby i Syrien, der blev erobret i 738 f.Kr. og siden endnu engang besejret efter et oprør i 720 f. Kr. Damaskus var hovedstaden i Syrien (Aram; jf. Jes 7,8) og blev erobret i 732 f. Kr. af Tiglat-Pileser III. Samme skœbne overgik endelig Samaria i 722 f.Kr. ${ }^{17}$

Opregningen af disse byer forudscetter, at teksten er senere end disse begivenheder, dvs. efter 717 f.Kr., men at angrebet på Jerusalem i 701 f.Kr. endnu ikke er effektueret.

I v. 10 skildres erobringerne med billedet af assyrerkongens hånd, der finder frem til afgudernes rige. Det siges ikke direkte, hvad hånden søger efter og tager fat om. Det kan vare gudebillederne i landene, eller pointen kan vœre, at assyrerkongen ikke blev standset, selv om landene havde mange guder, der burde have beskyttet dem mod angrebet. Glosen for afguder, אליל, betegner også intethed. Det er magtesløse guder, fx Jes 2,8.18.20. De nœvnte lande sammenlignes med Samaria og Jerusalem, der ikke har nœr så mange gudebilleder. Et gudebillede, sיפ, er et udskåret billede, som mennesker selv har lavet, Mi 5,12 (se også den parodiske skildring af, hvordan et gudebillede laves ifølge Jes 44,9-20, her omtalt som לog). Ifølge assyrerkongen er Samaria og Jerusalem dog ikke er uden afguder og gudestøtter, v. 11. Glosen for gudestøtte er עצב og bruges også nedvurderende i Jes 2,8 .

Logikken er klar nok, når byer med mange gudebilleder ikke har kunnet modstå den store assyrerkonge, hvor meget mindre kan så Samaria og Jerusalem, der er dårligere udstyret med gudestøtter, klare sig mod ham. Og derfor kan de forvente samme skœbne som de øvrige. Der er jo ikke nogen guder, der kan stå sig mod assyrerne.

${ }_{17}$ De her anvendte årstal bygger på Hans Wilderbergs kronologi, se Biblischer Kommentar Altes Testament, Bd. X/1 1972, 397-398. 
Hvad der her gengives som assyrerkongens foragt for afguderne, svarer altså til den gammeltestamentlige opfattelse, hvilket får nogle forskere til at se v. 10-11 som en senere tilføjelse, der skal underbygge Samarias og Jerusalems skyld i Jahves straf. De dyrkede afguder, og derfor måtte de straffes! Set i den nuvœrende kontekst er formålet at vise assyrerkongens overmod og hans opfattelse af Jahve, som her nedgøres til en banal gudestøtte i lighed med andre folks gudebilleder.

\section{2-15}

Efter denne klare trussel mod Samaria og Jerusalem følger i v.12-14 dels en kommentar, der fastslår, at Jahve efter at have straffet Jerusalem også vil straffe assyrerkongen på grund af hans hovmod, dels et citat, der skal dokumentere kongens hovmod. Kommentaren, v. 12, der er holdt i prosa, bryder den poetiske stil og har som formål at sikre, at løeseren forstår Jahve plan. Jahves plan har to dele, først gcelder det hans eget folk, så kommer straffen over assyrerne.

Jahve omtales i v. 12 som Herren, ארני, dvs. den overordnede. Hvad Herren vil foretage sig, omtales meget generelt som hans vœrk. Det afgørende er, at det er ham, der står bag de politiske begivenheder. Zions bjerg betegner stedet, hvor templet er, og hvor Jahve under normale omstcendigheder har sin bolig. Nu skal netop de, der bor i Jerusalem, taet på Jahves tempel, opleve hans indgriben. Det siges ikke direkte, at det er straffen over Jerusalem, der tcenkes på, men i den nuvœrende sammenhceng, må det forstås sådan. Fra omtale af Herren i tredje person skifter teksten nu til første person. Det er Jahve selv, der taler. Verbet פקד betyder her at hjemsøge med straf, og grunden er igen assyrerkongens hovmod, på hebraisk גדל לבב, hjertets storhed, og det, hovmodet har ført med sig, her kaldt frugten, פרי. Ordene om hans øjnes stolte pral, gפארת רום עיניו, genoptager motivet fra Jes 2,1 1, hvor det er menneskets stolte blik, der skal ydmyges, og mands hovmod skal bøjes (jf. at begge steder bruges gloserne for blik/øjne, עינים, og for hovmod, רום). Hvad der var et generelt udsagn i Jes 2,11 , er nu brugt om assyrerkongen.

Beviset på hovmodet er hans egne udtalelser, v. 13-14. Som det første nœvner assyrerkongen sin hånds kraft. Hvor det i vredesudsagnene, Jes 5,25; 9,1 1.16.20 og 10,4, er Jahves hånd, der er løftet og klar til at gribe ind, er det set ud fra assyrerkongens perspektiv hans egen hånd, der udvirker det hele. Udover at vœre kraftfuld betegner han sig selv som vis. Det er terminologi, som kendes fra visdomslitteraturen, hvor substantivet חכמה, visdom, i Ordsp 8,1 anvendes om den personificerede visdom, der var til fra verdens skabelse og gik Gud til hånde, Ordsp 8,22-31. Denne guddommelige visdom forbindes også med kongen i Ez 28,4 og er ifølge SI 51,8 og 90,12 en Guds gave. Også ver- 
bet בין er hyppigt anvendt om at have indsigt. Her og i Jes 5,21 er det anvendt i nifal (se også hitpaelformen i Jes 1,3). Den visdom, som hører Gud til, og som han kan lœere sit folk, erklœrer assyrerkongen sig nu som indehaver af. Vœegten ligger igen på, at det er min visdom, og at det er mig, der er klog. Visdommen har for det første vist sig deri, at han har fjernet grcenserne mellem forskellige folk. Ud fra et gammeltestamentligt synspunkt, er det Jahve, der har angivet grcenserne, Deut 32,8; SI 74,17. Selv de lokale grcenser må ingen œendre på, Deut 19,14; Deut 27,17. Nu sctter assyrerkongen sig i Guds sted.

Det er den samme selvovervurdering, der viser sig, når han haevder, at det er ham, der som den mœgtige har nedstyrtet dem, der sidder på tronen. At sammenligne sig selv med den magtige, אביר, er blasfemi. Jahve selv kaldes undertiden Jakobs eller Israels אביר, fx Gen 49,24; Jes 1,24; 49,26; 60,16 og SI 132,2.5. Glosen bruges om tyre, Jes 34,7, men overscttes fx i Jes 1,24 i DO 1992 ved Israels magtige, formentlig for at undgå den tanke, at man i Israel forestillede sig Jahve i skikkelse af en tyr (jf. dog Jeroboams guldkalve, 1 Kong 12,26-30, samt guldkalven i ørkenen, Ex 32, der fortcller, at man faktisk har lavet billeder af Jahve på trods af billedforbuddet i Ex 20,4-6; se ncrmere om brugen af dyrebilleder for Jahve i Kirsten Nielsen 2005). Når assyrerkongen hcevder, at han står bag de politiske omvceltninger, håner han Jahve, som er den, der styrer historien gang.

I v. 14 vender motivet med hånden tilbage. Med den finder han frem til de rigdomme, han vil samle sammen til sig selv. Sammenligningen med de forladte œeg, som han kan samle sammen, uden at fuglene skriger gevalt, skal vise den lethed, hvormed han kunne foretage sine erobringer. Hele verden lå åben for ham. Billedet af fuglereden minder om det billede, assyrerkongen Sankerib bruger i sin beretning om, hvordan han i 701 f.Kr. belejrede Jerusalem og byens konge: "Jeg spcerrede ham selv inde i hans kongestad Jerusalem som en fugl i bur. Jeg anlagde faste vœrker mod ham og betog ham enhver lyst til at gå ud af hans bys port." (jf. ovenfor s. 47). Kongen sammenlignes med noget så vcergeløst som en fugl i et bur. Her i Jes 10,14 er det hele verden, der er vœrgeløs over for assyrerkongen.

Som svar på assyrerkongens hovmodige udsagn kommer der i v. 15 nogle retoriske modspørgsmål, der skal sctte ham på plads som det redskab, han er og bliver. Assyrerkongen bytter om på forholdet mellem redskabet og den, der bruger det. Øksen og saven er netop ikke stcerkere end den håndvœrker, der bruger dem, og har derfor ikke noget at prale af. Det samme gœelder for kœppen og stokken. De kan ikke løfte den, der løfter dem. For det er ikke et stykke trœ, de er kommet i hcenderne på. Billederne er hentet fra håndvcrkerens verden og fungerer som argumentation for 
Jahves magt over assyrerkongen. Det selvfølgelige i billedet overføres til forholdet mellem Jahve og den jordiske konge. De to gloser, שמטה מט, kcep, stok, som også blev brugt i v. 5, gør det tydeligt, at det er assyrerkongen, der er redskabet, og at Jahve er den håndvœrker, der kan bruge det. Billedet runder på den måde veråbet og truslen om straf af.

\section{6-19}

I det følgende afsnit uddybes truslen om straf gennem billedet af en ild, der begynder som en feber $\mathrm{i}$ assyrerkongens krop, men breder sig som en skovbrand. Straffen skal underbygge den logik, der også var gennemgående i Jes 2, at hovmod står for fald. Billedet af ilden forbinder de to billeder, sygdommen og skovbranden. De flettes ind i hinanden ved gentagelse af centrale gloser: כבוד, pragt/herlighed, i v. 16 og v. 18; אשי, ild, i v. 16 og v. 17; skov, i v. 18 og v. 19. Grundtanken er, at den måde sygdomme udvikler sig på, og den måde skovbrande udvikler sig på, gœlder også for Jahves forhold til assyrerkongen. Alle ved, hvordan feberen raser og udmarver kroppen, og hvordan ilden œeder trœerne, og nu skal de se den samme udvikling i de politiske begivenheder, som Jahve scetter i gang mod assyrerkongen. De to billeder stammer fra forskellige områder af tilvœrelsen, men de har lighedspunkter. I v. 16 hedder det om den svindsot, som Jahve sender, at den skal brcende. Roden יקד betyder at brœnde og bruges her billedligt om sygdommen, men åbner dermed også op for skovbrandsbilledet. Assyrerkonges fede krop skildres i paralleludsagnet som hans pragt, כבור. Og samme glose kan bruges om en skovs pragt, den herlige skov, v. 18. At assyrerkongens krop omtales som fed er udtryk for, at han, indtil sygdommen rammer ham, har det godt. I ncerorientalsk kultur er fedme udtryk for velsignelse og velstand. Fedmen er dermed med til at understrege den markante forskel på før og efter.

Glosen ild, אש, som uddyber billedet af den brcendende feber i v. 16, bliver stikordet til det følgende vers, hvor Jahve betegnes som ildens årsag. Men hvor Jahve i v. 16 er Hœrskarers Jahve, dvs. den stcrke Gud, omtales han her billedligt som Israels lys. Netop lysfcenomener og ildfcenomener forbindes i Det Gamle Testamente med Jahve. Jahve kan omtales som lys, fx SI 27, 1, ligesom hans ord er som lys, SI 1 19,105, og hans ansigt er forbundet med lys, fx SI 4,7 og den aronitiske velsignelse, Num 6,25. I SI 97,1-5 afstedkommer Jahves tilsynekomst forskellige naturfœnomener, heriblandt også ild og flammer. I forbindelse med åbenbaringen på Sinaj er Jahve omgivet af ild (se Ex 19,18 og Deut 5,4; se også den brœendende tornebusk i Ex 3,1-6), og meget markant hedder det i Deut 4,24: "For Herren din Gud er en fortcerende ild, en lidenskabelig Gud." 
Jahves lidenskabelige karakter er forbundet med ilden, men hører også med, når Jahve omtales i v. 17 som den Hellige. Netop Jahves hellighed betyder, at han må afvise enhver, der forsøger at overtage hans plads i forhold til Israel. Ilden og lidenskaben, jalousien, hører sammen. Når der kun er den ene Gud for Israel, Ex 20,3, må han afvise alle andre, herunder også den hovmodige assyrerkonge, der optraeder, som var han selv en Gud.

Associationsgangen forløber fra sygdommen, hvor feberen kan føles som en brcendende ild, til den direkte beskrivelse af Jahve som lyset, der bliver til en flamme og fortcerer ikke blot tidsel og tjørn (jf. urettens rolle i Jes 9,17), men også assyrerkongens skov og frugthave, så nœsten intet bliver tilbage. Udtrykket מנפש וער־ברר יכלה, som i DO 1992 gengives ved "rub og stub", skal forstås ud fra billedet af en person, der tœeres op fra åndedraget til kødet, dvs. med alt hvad der hører til at vœre et menneske. Hermed markeres også, at tjørn og tidsel, skov og frugthave ikke skal forstås bogstaveligt, men som billeder på assyrerkongens rige med alle dets indbyggere, lav som høj. Også assyrerkongen skal rammes, så han til slut er helt tœret op. Gennem denne associationskœde knyttes Jahve tcet på ødelœeggelsen af assyrerkongen.

Det er da også mennesker, der tcenkes på, når der i v. 19 tales om trceerne i skoven, der bliver så få, at selv et barn kan tcelle dem (jf. brugen af trœet som billede på personer i fx Jes 1,29-31; 6,13 og שאר, angik i Jes 7,3 Judas rest, og var dér ment som en trøst. Der vil trods alt vare en rest tilbage. Her er resten udtryk for et minimum, som stort set kun kan bevidne, at der engang var et stort assyrerrige.

\section{0-27}

Det er glosen שאר, der skaber forbindelsen fra v. 19 til v. 20-23, men nu er det Israels rest, det gcelder. Redaktorerne har ved hjøelp af stikordet rest forsøgt at skabe sammenhceng mellem assyrerkongens skœbne og Israels skœbne. Deres skœbne ligner hinanden på den måde, at begge rammes af Jahves straf. Men der er også forskel. Israel har en virkelig forbundsfœlle, nemlig Jahve selv. Tidsangivelsen angiver et afgørende tidspunkt, hvor Jahve vil gribe ind i folkets historie (jf. faktaboksen s. 78). På det tidspunkt er der stadig en rest tilbage, nogle få som er undsluppet katastrofen (jf. Jes 4,2). Men hvor de hidtil har valgt at støtte sig til assyrerkongen, skal de nu i stedet støtte sig til deres Gud. Roden שען blev også anvendt i Jes 3,1 i form af substantiverne משען ומשענה, hvor støtte og stav omfattede alle dem, der normalt får et samfund til at fungere, herunder krigerne, dommerne og profeterne, spåmandene og de œldste. Den, de nu ikke mere skal støtte sig til, er assyrerkongen, som 
Judas konge, Akaz, indgik alliance med i forbindelse med den syrisk-efraimitiske krig, 2 Kong 16,7, i tillid til, at en storkonge nok skulle kunne hjœlpe ham mod fjenderne, Aram og Efraim (se også Jes 7,1-9). Politiske alliancer bliver i den jesajanske forkyndelse betragtet som udtryk for mistillid til folkets egentlige konge, Jahve. Igen omtales Jahve som Israels Hellige (se ovenfor s. 44; 57 og 93). Folkets venden tilbage til Jahve skal ske באמת, dvs. i oprigtighed. Roden אמן blev i Jes 7,9 brugt til at beskrive forholdet mellem Jahve og folket som et gensidigt pagtsforhold. Hvis ikke folket holder fast ved Jahve, så vil Jahve heller ikke holde fast ved dem. Det er netop denne loyalitet og gensidighed, der ligger bag udtrykket באמת. Til den tid vil de holde fast ved beslutningen om at støtte sig til Jahve.

Resten kaldes i v. 21 for Jakobs rest. Der er nceppe den store forskel på udtrykkene Israels rest og Jakobs rest. Begge betegnelser er karakteristiske for Deuterojesaja, fx Jes 40,27; 41,8; 42,24, hvilket igen viser, at der er forbindelseslinjer mellem Proto- og Deuterojesaja. Det afgørende er, at disse navne peger tilbage til stamfaderen og dermed forjœttelserne om, at de skal blive til et stort folk og få det forjœettede land, fx Gen 28,13-15. At Jahve samtidig kaldes den valdige Gud, אל גבור;, viser, at der også står magt bagved. En גבור er en helt, der viser sin styrke i krigen (se omtalen af den nye konge i Jes 9,5-6 samt beskrivelsen af Jahve som vœldig i krig i SI 24,8). Udtrykket, talrigt som havets sand, כחול הים i v. 22, giver mindelser om forjcettelserne til patriarkerne om folkets store udbredelse, fx Gen 22,17; men med tilføjelsen om resten markeres det, at kun et fåtal vil vende om. Beslutningen om straffen står fast, og hvad der sker, er udtryk for Jahves vilje og retfœrdighed. Med v. 23 understreges ifølge DO1992 omfanget af tilintetgørelsen, den omfatter hele jorden. På hebraisk står der "midt i hele verden", hvilket i denne sammenhceng må betyde, at det er Jahves eget folk, der rammes. Også skildringen af assyrerkongens march frem mod Jerusalem, Jes 10,28-32, understøtter denne tolkning.

Motiverne i det følgende orakel, v. 24-27, er velkendte. Det er et Jahveudsagn, som profeten videregiver (jf. sendebudsformlen, כה־אמר יהוה, som hyppigt indleder profetiske orakler, se ncermere s. 36-37). Ligesom Jahve i Jes 7,4 trøstede kong Akaz og opfordrede ham til ikke at vare bange for de to konger, der truede med at erobre Jerusalem, således beroliger Jahve her Jerusalems beboere. Udtrykket "Frygt ikke!" bruges i den deuterojesajanske forkyndelse som indledning til frelsesorakler, fx Jes 41,10; 43, 1.5. Ved at kalde folket עמי understreger Jahve samhørigheden, de er mit folk. Omtalen af Zion, som er stedet, hvor Jahve bor, har samme funktion. Assyrerkongen er ikke ufarlig, han skal bruge sin kœp, שבט, mod dem og løfte sin stav, מטה, mod dem (jf. Jes 10,5, hvor assyrerkongen netop er Jahves vredes kœp og stok). Hvad der tœnkes på med henvisningen til det, der skete på vejen til 
Egypten, er ikke klart. Assyrien indgår ikke i de traditioner om Egypten, som omtales mere udførligt i v. 26. Der må derfor vœre tale om andre begivenheder, som datiden kendte til, men som det er vanskeligt at rekonstruere i dag. Dog fremgår det af Det Gamle Testamente, at Egypten og Assyrien på Jesajas tid indgik i diverse magtkampe, og at kong Hizkija gjorde oprør mod assyrerne i tillid til hjcelp fra Egypten (jf. 2 Kong 18,21/Jes 36,6; se også Jes 18-20). Assyrernes march ned langs den fønikiske kyst mod Jerusalem kan også have haft Egypten som mål, så Egyptensvejen kan betyde på vej i retning af Egypten. I DO 1992 er vejen, דרך, ikke blevet opfattet som en konkret vej, men snarere som den måde, hvorpå noget sker.

Trøsten til folket ligger i, at der kun er kort tid tilbage, før Jahve slår til mod assyrerne, v. 25. Når Jahves vrede mod hans eget folk er forbi (jf. vredesudsagnene i Jes 5,25; 9,7.12.16.20 og 10,4 samt takken over vredens ophør i 12,1), så vil vreden rette sig mod assyrerne. I det følgende vers, v. 26, sammenlignes Jahves straf over assyrerne først med sejren over midjanitterne ved Orebs klippe (jf. Dom 7, hvor dommeren Gideon med ganske få mand besejrer den langt større fjende; se også Jes 9,3). Jahve er nu udstyret med en pisk, hvormed han scetter sin magt igennem. Yderligere inddrages begivenhederne ved udfrielsen fra Egypten, hvor Moses på Jahves befaling skilte vandene ved at holde sin stok, מטה, ud over havet, så israelitterne kunne gå tørskoet over og undslippe egypterhceren, Ex 14,16-22.

Vers 27 indledes med den velkendte formel, והיה ביום ההוא, på den dag (se nœrmere s. 78). Indholdsmcessigt er der tale om en genoptagelse af motivet fra Jes 9,3 (jf. at også Midjan var omtalt i Jes 9,3). Her er der ingen tvivl om, at byrden og åget, som Jahve skal fjerne, er assyrerkongens magt. Ud over hvad der siges i Jes 9,3, hedder det nu, at åget på skulderen (se s. 146 om trœkdyrmetaforik) skal sprœnges på grund af fedme. I Jes 10,16 blev assyrerkongens krop beskrevet som fed. Fedme er, som tidligere nœvnt, udtryk for velsignelse. Nu er det Guds folk, der skal opleve velsignelsen og dermed komme fri af de ulykkelige forhold, som de hidtil har lidt under. Ved på denne måde at genoptage tidligere motiver har redaktorerne villet understrege sammenhcengen i Jahves handlinger. Alt hvad der sker, sker efter hans vilje.

\section{$28-32$}

Herefter gives der en levende skildring af assyrerhcerens hastige fremmarch mod Jerusalem (jf. Jes 10,9-11). Nogle forskere ser dette afsnit som en gengivelse af begivenhederne i 701 f.Kr., hvor Sankerib på sit sejrstogt når frem til Jerusalem og indleder belejringen af byen. Den rute, der følges i v. 
28-32, svarer dog ikke ganske til Sankeribs, eftersom Sankerib angreb Jerusalem fra vest og ikke fra nord. Men som ncevnt ovenfor hører det med til datidens forestillinger, at fjenden kommer fra nord. Skildringen kan derfor meget vel have til formål at genkalde traditionelle forestillinger om den valdige fjende samtidig med, at man ud fra konteksten forstår, at det er assyrerkongen, der kommer og truer Jerusalem, sådan som det skete i $701 \mathrm{f.Kr}$.

Ruten går gennem en rakke byer, hvoraf en del kendes fra Det Gamle Testamente, men den svarer heller ikke til, hvad man ville forvente af en rute fra nord mod syd. Dette kan naturligvis tolkes sådan, at fjenden valger at lave et overraskelsesangreb. Det vigtigste er dog, at fjenden kommer nœrmere og nœrmere Jerusalem, og ingen kan standse ham, alle gribes af rœdsel.

Skildringen indledes ubestemt med verbet i 3. person sing. mask. Det prœeciseres ikke hvem, der kommer, blot at første station på vejen er Ajjat. Men lœst i konteksten er man ikke i tvivl om, at det er assyrerkongen. Ajjat er formentlig byen Aj, som kendes fra traditionerne om Josua, der erobrer byen under indvandringen i Det Forjœttede Land, Jos 7,2-8,29. Herefter følger Migron, der må ligge mellem Aj og Mikmas. Mikmas er et strategisk vigtigt pas, som er omtalt i beretningerne om krigen mod filistrene, hvor det lykkedes at fordrive dem fra Mikmas (jf. 1 Sam 13,23 samt 1 Sam 14,4-5.31). At de efterlader trosset, dvs. den tunge del af det materiel, som de har med i krigen, viser, at nu skal de øge hastigheden og ikke lade sig sinke. Nattens lejr finder sted i Geba, der ligger i Benjamin stamme, Jos 18,24, og under kong Asa befœstes for at beskytte Judas nordlige grœnse, 1 Kong 15,22. Rygtet om hceren når frem til Rama, en by i samme område og kendt fra traditionerne om Rakels gråd over de døde børn, Jer 31,15. Sauls Gibea er, som det fremgår, knyttet til traditionerne om Saul, der bl.a. bliver grebet af profetisk henrykkelse i Gibea, 1 Sam 10,10. Efter kongevalget drager Saul hjem til Gibea ifølge 1 Sam 10,26 (se også 1 Sam 22,6). Men også Sauls Gibea giver efter og flygter for fjendens hœr.

Bat-Gallim er ligeledes kendt fra Saultraditionerne, 1 Sam 25,44. Lajsha ncevnes kun her, mens Anatot er omtalt 1 Kong 2,26 som stedet, hvortil Salomo forviser prcesten Ebjatar, som havde støttet Salomos bror Adonija i kampen om tronen. Madmena og Gebim er kun omtalt her, men omtales som eksempler på dem, der flygter. Til sidst er hœren nået til Nob, byen hvor David søgte tilflugt for Saul, og hvis prœsteskab til gengœeld blev nedslagtet af Saul, 1 Sam 22. Nu er assyrerkongen kun få kilometer fra sit mål og kan med hånden true Jerusalem.

Der gives ganske få oplysninger om marchen ud over bynavnene. Hele skildringen viser en hastig fremrykning, hvor befolkningen i de nœvnte byer gribes af rœdsel. I v. 30 opfordres Bat-Gallim 
til at gøre anskrig. De to nœeste opfordringer, הקשיבי, lyt efter, og עניה, giv svar (verbet עניה lœeses som en imperativ energicus i femininum), kan tolkes sådan, at byerne forsøger at komme i kontakt med hinanden, men lœseren fornemmer, at der ikke er tid til hverken at sende meldinger eller vente på svar. Hœren er allerede hastet forbi.

Ved hjœlp af ordspillene i v. 30-31 mellem bynavnet Anatot og opfordringen til at svare, עניה ענתות, samt mellem bynavnet Madmena og verbet flygte, נדרה מדמנה, sker der en intensivering af sproget. To og to spejler gloserne hinanden, som var der kun tid til et enkelt udtryk. Skildringen af den hastige march har som formål at skabe den samme angst i lœeseren og at gøre lœseren samtidig med begivenhederne. Nok ser redaktorerne tilbage, men for lceseren er det endnu i dag, עוד היום, den fremmede hœr truer hovedstaden.

Assyrerkongens truende attitude over for tempelbjerget, Zion, er det sidste signal inden erobringen skal påbegyndes. Verbet נוך betyder at svinge med noget og bruges også i Jes 11,15, hvor det er Jahve, der ved at svinge hånden sender en vœldig storm, der får floden til at spalte sig, så israelitterne kan gå tørskoet over. Den løftede hånd er magtfuld (jf. også Jahves løftede hånd i vredesudsagnene, se Jes 5,25 m.fl.), men denne gang er det ikke Jahves hånd, det er assyrerkongens hånd. Og det gør en forskel. Gennem veråbet og truslerne i det foregående er der lagt op til, at den, der for alvor kan løfte hånden, er Jahve selv. Men det forudscetter, at Jahve vil redde sit eget folk. At assyrerkongen vover at true selveste tempelbjerget viser hans hovmod, for han forstår ikke, hvem der er den egentlige herre over byen (jf. Jes 7,7-9, hvor den poetiske skildring af hvem, der har magten i Aram og Efraim, nok skal suppleres med et udsagn om Jahve som Jerusalems hoved). Også skildringen af assyrerkongens forsøg på at overraske og erobre Jerusalem er udtryk for hans hovmod.

Tilbage til indholdsfortegnelsen

\section{Jes 10,33-11,9}

\section{Tekstkritik}

$11,4 \mathrm{~b}$

ארץ, Iandet, rettes til ערץ "voldsmanden" med BHSb. Der er ingen hebraiske tekster eller gamle oversœttelser, der kan understøtte tekstrettelsen. Ud fra konteksten giver det dog bedst mening, at paral- 
lellen til den uretfcerdige, רשע, er en voldsmand og ikke hele landet. Da ordet ארץ desuden forekommer lige forud, kan der vare tale om en simpel afskriverfejl.

\section{$11,6 a$}

ימריא betyder fedekvœeg, se Jes 1,11. En direkte oversœttelse ville derfor lyde: "kalv, ungløve, fedekvœeg sammen", og man ville savne et verbum. DO har derfor rettet til et verbum, at grœsse. Det er i så fald et verbum מרא, der kun findes her, men som må betyde at mceske sig.

\section{Karakteristik}

Afgrcensningen af afsnittet er diskutabel. De allerfleste forskere betragter Jes 10,33-34 som en del af kap. 10 og 1 1,1-9 som et selvstcendigt afsnit. Hvad der dog taler for at se disse vers som et sammenhœngende hele er billedbrugen (se Kirsten Nielsen 1985, 170-203). Lœst i forlcengelse af hinanden beskriver versene det samme scenarie som i Jes 6,13: Når et trœ fœldes, står kun stubben tilbage, men stubben er i stand til at spire igen. Trœbilledet, som er meget hyppigt anvendt i Jes 1-12, formår at formulere den sammenhceng mellem dom og frelse, som er karakteristisk for den jesajanske forkyndelse. Straffen er nødvendig, der må en renselsesproces til, før den nye tid kan indtrceffe, Jes 1,25-28 og 4,4-5, og der må ske en decimering, før den gode rest kan udskilles, Jes 7,3; 10,18-23. På samme måde er fœeldningen af trœerne en forudsœtning for den nye spire. I Jes 6,13 er det formentlig Davidsdynastiet, der tcenkes på som den hellige sced. I Jes 11,1 er helt klart et skud af Davidsslœgten, Isajs slœgt, der skal gro frem.

Jes 10,33-34 skal naturligvis også lœeses i forlœengelse af kap. 10. Og på grund af billedsproget er det muligt at udlœgge billedet på to forskellige måder. Lœst i forlœengelse af Jes 10,28-32, som er en skildring af assyrerkongens fremmarch mod Jerusalem, kan fœldningen af de store trœer tolkes om den stolte assyrerkonge, der har overskredet sin kompetence, fx Jes 10,12, og hans hœr. Nu vil Jahve selv standse dem. Den nye vœkst er dog under alle omstcendigheder at finde i Juda. Meningen må i så fald vare, at med Jahves besejring af assyrerkongen bliver der plads for Jerusalems konge. Lœst som baggrund for Jes 11,1 må Jes 10,33-34 derimod dreje sig om en decimering af Juda, evt. af kongeslœgten, før den nye konge af Davids slœgt kommer. Juda er da set i billedet af det ypperste tra fra datiden: Libanons cedertrceer, der netop anvendtes til bygning af paladser og templer. 
Det kan diskuteres, om der er tale om et oprindeligt sammenhangende orakel eller en redaktionel sammenstilling af Jes 10,33-34 og 11,1. Under alle omstcendigheder er de to kapitler forbundet via trœbilledet. Derved påstås det, at der er sammenhœeng mellem Assurs fald og Judas nye blomstring. Hvem der primcert tcenkes på med billedet af Libanons trœer, er måske ikke så afgørende endda, når man lœser den foreliggende tekst. Lœseren skal muligvis have både den stolte assyrerkonge og den ulydige konge i Juda i tankerne. Begge skal opleve at blive faldet af Jahve; men det er Isajs stub (og ikke assyrerkongens), der skal spire igen.

Beskrivelsen af den nye konge minder om beskrivelsen af kongen i Jes 9,5-6. Det er en idealkonge, der lever op til alle de forventninger, der kendes fra SI 72. Hans egenskaber svarer til tronnavnene i Jes 9,5-6, men skildringen af hans rige som et fredsrige er stcerkt udvidet og inddrager også dyreverdenen. Jes 11,1-9 kaldes af mange en messiansk forjœttelse og er blevet fortolket om en Messias, der hører en fjernere fremtid til. I kristendommen tolkes denne Messias som Jesus (se ncermere om den nytestamentlige tolkning af Jesus som Messias i DKDSI, 137-138).

\section{Struktur}

10,33-34 Domsudsagn: Jahve fœlder de store trœer.

11,1-5 Frelsesudsagn: En retfœrdig konge skal spire frem af Isajs stub.

11,6-9 Skildring af det kommende fredsrige.

\section{Fortolkning}

33-34

Disse vers udnytter billedet af Jahve som skovfœlder (jf. Jes 2,12-17; 4,2-6; 6, 12-13; 14,4b-20; 32,1520; 37,22b-32 samt Ez 31). Det er karakteristisk for dette billede, at selv om trceet fceldes, så er dets liv ikke endeligt ødelagt. Anderledes er det med de billeder, hvor trcerne rammes af skovbrand og brcender op (se Jes 1,29-31; 9,7-20; 10,16-19). ${ }^{18}$ At der er tale om en voldsom begivenhed fremgår bl.a. af de navne, der bruges: האדון יהוה צבאות. Jahve er Herren, Hœrskarers Jahve og dermed i stand til at føre krigen mod sit folks fjender sejrrigt igennem. Selve fœldningen vœkker rœdsel (jf. fx SI 48,6, hvor Jahves tilsynekomst vœkker rœdsel hos fjenderne).

\footnotetext{
${ }^{18}$ Se også vingårdsbilledet i Jes 5, 1-7, hvor vinstokkene afgnaves som straf. Dog kan roden בע også betyde "afbrcende" Jes 5,5. Samme glose findes desuden i Jes 6,13 som betegnelse for ødeløggelse.
} 
Motivet med store og knejsende stammer indgik i domsskildringen i Jes 2,12-17, hvor det at vœre høj og knejsende tolkes som udtryk for hovmod. Men hovmod står for fald! Følgende gloser

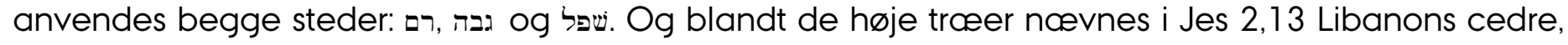
mens det i Jes 10,34 blot hedder, at Libanon falder. Der er dog ingen tvivl om, at det er trcerne på Libanon, der tcenkes på.

Billedet af skovfœeldningen er umiddelbart forståeligt på baggrund af de forudgående kapitler. Men det er sandsynligt, at henvisningen til Libanon også fungerer som markør for en gammel myte, der handler om overgreb på Libanons trceer. Myten foreligger kun i brudstykker og må derfor rekonstrueres. Den handler om, at der på toppen af Libanon findes en gudshave, hvor der er nogle sœrlige trœer (jf. Gen 2-3 samt Ez 28,12-19). Haven udscttes for ødelœggelse, enten fordi en fremmed begår overgreb på den, eller fordi Jahve selv ødelœegger traeerne. I Jes 14,8 og 37,24 / 2 Kong 19,23 er ødelœeggelsen opfattet negativt som en voldshandling, som den skyldige fortjener at blive straffet for. Når det derimod er Jahve, der fœlder trœerne, så fremgår det, at det er p.g.a. trceernes hovmod og derfor velfortjent (jf. Jes 2,13 og Ez 31 ). Denne myte appliceres nu i Jes 10,33-34 på Jerusalem, der billedlig talt er som en have fyldt med trcer. Byens beboere tror, at de er Guds udvalgte, fordi de bor i Jerusalem, Guds Have; men de skal straffes for dette hovmod.

\section{$1-5$}

Dette afsnit bliver af nogle forskere betragtet som eftereksilsk, idet de tolker det faldede trœ, stubben, i v. 1 om kongedømmets ophør. Dette er dog ikke nogen nødvendig tolkning. Billedet kan udmcerket tolkes om fjernelsen af en konge, som ikke lever op til Jahves krav, men skal efterfølges af en god og lydig konge. En af mulighederne er da, at Akaz er den dårlige konge, mens sønnen Hizkija er den, man sctter sine forventninger til (jf. tolkningen af Jes 9,5-6). Billedet er i sig selv netop så åbent, at det giver mulighed for nytolkning, når den politiske situation cendrer sig. Trœbilledet er, som nœvnt, en yndet metafor i Jesajas forkyndelse, da det kan bruges til både at fortclle om fœldning og om ny spirekraft, hvilket giver en god sammenfatning af Jesajas centrale budskab: Dommen er uomgcengelig, men trods alt er der håb for en rest.

Vers 1-5 skildrer den kommende hersker som idealkongen (jf. SI 72 og Jes 9,5-6). At kongen skildres som et trœ hører med til den orientalske kongeideologi (jf. Jes 53,2 og Dan 4,7-24). Vers 1 indledes med et verbum i weqatal, hvorved der knyttes til ved det foregående, men hvad der fortœlles gœlder fremtiden. Vi er også i dette vers inden for den botaniske kode, når det er et plantebil- 
lede, der følger efter skovbilledet. De to gloser נצר og מטר betegner nye skud, men det overraskende er, at billedet herefter delvis brydes, når det, de skyder frem fra, kaldes גזע ישי. Isaj er navnet på Davids far, og hermed forlader vi for et øjeblik billedsproget. גזע er derimod et billede. Glosen bruges i Job 14,8 om en rodstub, der sctter nye skud. Det parallelle udtryk שר ש bruges om selve roden og anvendes ofte billedligt. I Hos 9,16 hedder det fx, at Efraims rod er udtørret, mens Israel i Hos 14,6 får løfte om at slå rod som Libanon. Hvad det drejer sig om i Jes 11,1 er derfor Isajs slagtstra, og det nye skud er Isajs søn. Hermed understreges, at det er en ny David, der skal komme.

Som tidligere nœvnt er det ikke helt klart, når man lœser kap. 10 og når til v. 33, hvem Jahve vender sig imod som en skovhugger. Umiddelbart må man forvente, at det er assyrermagten, dvs. fjenden. Med v. 34 kommer et stednavn, Libanon, der dog snarere leder tanken hen på Juda end på Assur. Og endelig giver personnavnet Isaj endnu en nøgle til tolkningen. Formålet med trœfœeldningen er at give plads for den nye David, den kommende Messias.

\section{Faktaboks: Messiasforestillingerne}

Forjœttelserne om den kommende konge i Jes 9,5-6 og 11,1-9 kaldes også for messianske forjœttelser. Messias betyder den salvede og bruges netop om kongerne, da disse salves til deres embede (se fx salvningen af Saul i 1 Sam 10,1 og David i 1 Sam 16,13). Betegnelsen, den salvede, bruges i Det Gamle Testamente dog ikke blot om konger, men også som betegnelse for yppersteprœsten, den salvede prœst, Lev 4,3. Den salvede bliver efterhånden en teknisk term for den frelserkonge af Davids slœegt, Messias, som skal komme og genoprette storhedstiden. Da kongen ikke blot opfattes som en politisk aktør, men også har en sakral rolle som forbindelsesled mellem Gud og folket (jf. kongen som sakral konge i SI 2; se ncermere i Holt og Nielsen 1999,78-79.238-239), bliver Messias også en religiøs figur. I eftereksilsk tid udvikler disse forestillinger sig, så man både forventer en kongelig Messias og en prœstelig Messias (se ncrmere i Zak 4,14; 6,13). Der sker tydeligvis også en nytolkning af steder som Jes 9 og 11, så de opfattes som forudsigelser af denne Messias. Messiasforestillingerne har deres rod i salmernes kongeideologi (se SI 72; 110; 89,20-38 og 45,7). Men hvor salmerne fx har varet brugt ved kongens tronbestigelse og udtrykker ønsker og forhåbninger for den aktuelle konge, udnytter profeten disse forestillinger til at skildre den kommende konge. Og efterhånden som forventningerne ikke bliver opfyldt af de aktuelle konger, skydes forventningerne ud $\mathrm{i}$ fremtiden, hvor den ideelle konge, Messias, skal komme. Den rituelle fejring af kongen i kulten i Jerusalem ophører med kongedømmets fald i forbindelse med det babylonske eksil i 6. årh. f.Kr.. Men af kultens forestillinger bevares forventningen om den dag, hvor Israel får en retfœrdig konge. Disse forestillinger ligger også bag Det Nye Testamentes tolkning af Jesus som Messias; men den nytesta- 
mentlige tolkning er netop en nytolkning, hvor bl.a. sejren over de nationale fjender er kraftigt nedtonet (se ncrmere i DKDSI, 127-148).

Skildringen af den nye David understreger hans nare forbindelse til Jahve. Han er udstyret med Jahves ånd, רוח, v. 2. I beskrivelsen af forholdet mellem kong Saul og den unge David hedder det, at Jahve på et tidspunkt sender en ond ånd over Saul, 1 Sam 18,10 og 1 Sam 19,9. Dette sker netop som David også i praksis har vist, at han har den kongelige ånd (jf. 1 Sam 16,13, hvor Jahves ånd griber David), der har gjort ham i stand til at drcebe filisterkœmpen Goliat, 1 Sam 17.

Ånden er dog ikke kun en ånd, der kan få kongen til at udføre bedrifter, den indeholder også visdom og indsigt. Gloserne בינה er velkendte fra visdomslitteraturen, men også i traditionerne om kong Salomo understreges nødvendigheden af visdom. Da Jahve tilbyder Salomo at få et ønske opfyldt, vœlger han hverken langt liv, rigdom eller sine fjenders død. Han beder i stedet om et lydhørt hjerte og evne til at skelne mellem godt og ondt. Jahve bønhører Salomo, men giver ham ikke blot visdom og forstand i hjertet, han giver ham også rigdom, œre og et langt liv, 1 Kong 3,5-14.

Råds og styrkes ånd, רוח עצה וגבורה, svarer stort set til tronnavnene, Underfuld rådgiver, פלא יועיץ, og Vaeldig Gud, אל גבור, i Jes 9,5. Kundskabsånden indeholder ligeledes elementer, der findes i tronnavnet om evnen som rådgiver. Men hvor Jes 9,5 kan bruge selve glosen אל, Gud, om idealkongen, så bruger Jes 11,2-3 to forskellige udtryk til at formulere kongens ncerhed til Jahve. Han har Jahvefrygtens ånd, ja, han indånder den. Formuleringen kan minde om Jahvistens beretning om skabelsen af Adam, der af Gud får indpustet livsånde i nœeseborene for at blive til et levende vœesen, Gen 2,7. Men glosen for livsånde i Gen 2,7 er ikke רוח, men en tilsvarende glose: נשמת חיים.

Konsekvensen af Jahvefrygtens ånd viser sig i måden at herske på. Hvor andre dommere kan anklages for partiskhed (jf. Jes 1,23), dømmer idealkongen ikke efter det ydre. Han bøjer ikke retten, fordi stormand og andre velhavere har midler til at bestikke ham. Derfor får de svage deres ret, når han fœlder dom (jf. formaningen i Jes 1,17).

Tilsvarende straffes voldsmœend og uretfœerdige, v. 4. Mundens stok er de domme, han fœlder, når han erklcerer den skyldige skyldig og idømmer ham straf. Glosen for stok, שבט, kan også bruges om det kongelige scepter. I Gen 49,10 ncevnes det, at dette scepter ikke skal vige fra Juda stamme (David hører til denne stamme), og i den kongelige bryllupssalme, SI 45,7, forbindes kongescepteret med retfœrdighed. Kongen er billedlig talt klœdt på til sin dommergerning, når han if. v. 5 har retfœrdighed, צרק (se nœrmere om retfcerdighed i gennemgangen af Jes 5,7 og 9,6) og trofast- 
hed, אמונה, som bcelte. Retfcerdighed og trofasthed findes ofte som paralleludtryk i Salmernes Bog, SI 33,4-5; 36,6-7; 40,11; 88,12-13; 96,13, men ikke om den jordiske konge. Udtrykket gœlder Jahve selv. Også herigennem markeres ncrheden mellem idealkongen og Jahve. Når en kriger spœnder sit bcelte, betyder det, at han er klar til at gå i krig, Jes 8,9.

\section{6-9}

Det kommende fredsrige er endnu en konsekvens af den ideelle konges styre. Også i naturens verden er kaos afløst af kosmos. I Jes 9,5 blev den nye konge kaldt Freds Fyrste, שרי־שלום. Og det er netop et scrligt aspekt af freden, der tages op i Jes 11,6-9. Fred omfatter ikke blot de politiske og sociale forhold, men også naturen. Ud over at vœre frugtbar (jf. SI 72,16) skal naturen også vœre prœget af harmoni. Ifølge Gen 1,29-30 var både mennesker og dyr skabt som plantecedere, hvilket er en vigtig forudsctning for et harmonisk forhold mellem dyr og mennesker. Først efter den store vandflod bringes harmonien til ophør, og dyrene får grund til at frygte menneskene, idet mennesket får tilladelse til at spise dyr, dog uden at spise dyrenes blod, Gen 9,2-4. Også beretningen om Adam i Gen 2 giver indtryk af et fredeligt forhold mellem dyr og menneske i Edens Have, når Gud endog forventer, at Adam kan finde sin partner blandt dyrene, Gen 2,18-20. Fredsriget får dermed karakter af en Paradistilstand, en tilstand, der svarer til, hvad Gud oprindelig ønskede for verden. Tanken om fredsriget genoptages i slutningen af Jesajabogen lige inden skildringen af den nye himmel og den nye jord, Jes 65,25.

De dyr, der ncevnes som eksempler, er hentet fra to grupper: de vilde dyr og husdyrene. Normalt er husdyrene truet af de vilde dyr. Det paradisiske består da i, at de vilde dyr ikke lcengere vil overfalde husdyrene og œde dem, for de er atter blevet planteadere. Det almindelige byttedyr for en ulv og en panter er får, lam og gedekid. Ulven ncevnes i Ez 22,27 som et dyr, der "sønderriver bytte", og ulve omtales flere steder som nattedyr, Hab 1,8; Sef 3,3. Panteren ncevnes parallelt med ulven i Hab 1,8, hvor det er dyrets hurtighed, der peges på. Hvad der er grund til at frygte er i øvrigt dens evne til at gemme sig og ligge på lur efter sit bytte, Jer 5,6; Hos 13,7. Selv den unge løve grcsser nu sammen med kalven. Løver betragtes i Det Gamle Testamente som det farligste blandt dyrene. Det fremhceves derfor i beretningerne om den unge David, at når en løve eller en bjørn gik på jagt i hans fars hjord, så gik han til modangreb og rev byttet ud af gabet på de vilde dyr, 1 Sam 17,34-37. Det er en kongelig dåd at kunne besejre en løve (se Kirsten Nielsen 2005). 
Når hyrder var udstyret med stok og stav, SI 23,4, var formålet med stokken netop, at hyrden skulle forsvare sin hjord mod vilde dyr. At vœre hyrde var et krœvende arbejde, men under fredsriget kan selv en lille dreng varetage opgaven, for de vilde dyr jager ikke lœngere efter bytte. Nœrheden mellem de to dyregrupper, vilddyr og husdyr, understreges ved hjœlp af den fœlles føde. De grœsser sammen (eller bliver fede sammen; jf. tekstrettelsen). Føden, som før var stridspunktet, er nu blevet det, der forener dem.

Tanken føres videre i v. 7, hvor det er koen og bjørnen, der bliver venner, og løven og oksen, der œder grœs sammen. Bjørne er farlige for både dyr og mennesker (se 1 Sam 17,34 samt 2 Sam 17,8, hvor bjørnens farlighed anvendes som billede på David og hans mœnd). Her synes endog køer og okser, meget store dyr, at vœre blandt de dyr, der under normale omstcendigheder har grund til at frygte bjørne og løver. Men nu lever de tcet på hinanden, deres unger vokser op sammen, og løven er blevet planteceder.

Med v. 8 inddrages endnu en form for vilde dyr: slange og hugorm. Der er et naturligt fjendskab mellem dem og menneskene p.g.a. slangernes bid. Den glose, der bruges om slange, פת, angiver en giftig slangeart, fx Deut 32,33; SI 58,5 og Job 20,14. ${ }^{19}$ Hugormen, omtales ligeledes, fordi den er giftig, Jer 8,17 og Ordspr 23,32. Netop børn er udsat for bid, da de kravler rundt på jorden og under deres leg ikke er opmcerksomme på de farer, der truer, når de ncermer sig slangens eller hugormens huler. Men nu er der fred og ingen fare. Selv slangerne er holdt op med at bide menneskene (jf. Gen 3,15, hvor kampen ikke er ophørt, men mennesket dog er i stand til at knuse slangens hoved).

I sammenfatningen af hvad fredsriget indebcrer, v. 9, vendes fokus mod menneskenes verden. Budskabet er det samme som i de tidligere vers. De svage skal ikke lœengere frygte for at blive offer for de stcerke, når ingen lœengere gør noget ondt: לא ירעו. Hvad, der var en del af formaningen i Jes 1,16: "Hold op med at handle ondt!" חדלו הרע, bliver nu til virkelighed under den nye konges styre. Videre hedder det, at ingen mere skal volde ødelœggelse, שחת. De ulydige "børn", som i Jes 1,4 blev beskrevet som forbrydere, משחיתים, skal ikke lœngere opføre sig som forbrydere. Harmonien breder sig også mellem mennesker indbyrdes. At den nye tid er en scrlig tid fremgår desuden af omtalen af Jahves hellige bjerg, Zion (se også Jes 65,25, der alene ncevner bjerget og ikke landet). Netop som

${ }^{19}$ Det er ikke samme glose som i Gen 3, hvor det er det mere hyppigt anvendte ord for slange, un, der anvendes, Gen 3,1.14-15. 
den hellige kan Jahve ikke forliges med ondskab. Kundskab om Jahve fører ikke blot til denne indsigt, men også til, at man afstår fra at øve ondt.

Hele landet skal vare fyldt af Jahvekundskab. Mens kundskaben i Jes 11,2 er kundskabs ånd og forbindes med kongen selv, tales der her om Jahvekundskab hos alle. Billedet af vandet, der dcekker havets bund, skal netop betegne totalitet. At alle får del i de kongelige egenskaber afspejler en tendens til demokratisering, når det, der oprindelig blev tillagt Gud selv (kundskaben, jf. Gen 3), her videreføres til kongen og derpå til alle mennesker.

Tilbage til indholdsfortegnelsen

\section{Jes 11,10-16}

\section{Tekstkritik}

Der er ingen grund til at rette i teksten.

\section{Karakteristik}

Afsnittet består dels af et vers, v. 10, der skal forbinde Jes 11,1-9 med resten af kapitlet, dels af et frelsesorakel. Frelsen består i, at Jahve på den dag vil bringe de fordrevne af folket hjem og genoprette freden i landet. At v. 10 skal fungere som forbindelsesled kan ses af genbrugen af terminologi fra $\mathrm{v}$. 1, Isajs rodskud, og fra v. 12, banneret, der skal samle folket. Dertil kommer de to temaer: folkene, der skal komme hjem til Jahve, hvilket svarer til hovedindholdet af v. 11-16, og omtalen af Jahves herlige bolig, der korresponderer med omtalen i v. 9 af det hellige bjerg. De fleste forskere betragter såvel v. 10 som v. 11-16 som senere end kapitlets første afsnit. Dateringen bygger på tolkningen af de politiske forehold, der skildres, og som passer godt på den eftereksilske periode, hvor hjemkomsten og de deraf følgende stridigheder spiller en stor rolle (se ncermere i fortolkningen nedenfor).

\section{Struktur}

10 På den dag skal Isajs skud stå som banner for folkene.

11-12 På den dag skal Jahve bringe Israels og Judas fordrevne hjem fra de fremmede lande.

13-14 Genoprettelsen af forholdet mellem Efraim og Juda og den falles krig mod fjenderne. 15-16 Jahve skaber en banet vej hjem fra Assyrien svarende til hjemkomsten fra Egypten. 


\section{Fortolkning}

10

Med v. 10 har redaktionen knyttet de to dele af kapitlet sammen, så det bliver klart, at forudsctningen for den endelige tilbagevenden til landet er genoprettelsen af Davidsriget med en ny konge, $v$. 1-9. Den nye konge navnes ikke i v. 11-16, hvor det er Jahve, der styrer begivenhedernes gang og sørger for, at der også er nogle, der kommer hjem og bor i landet. Historisk set kan dette afspejle, at teksten er blevet til på et tidspunkt, hvor den jordiske konge ikke løengere spiller nogen rolle, dvs. eftereksilsk tid. ${ }^{20}$ En tilsvarende forskydning fra den jordiske til den himmelske konge kendes fra Salmernes Bog, hvor SI 89 beskriver forkastelsen af den jordiske konge, mens salmerne om Jahves tronbestigelse beskriver Jahve som den egentlige konge, fx SI 93 og 97.

Indledningsformlen והיה ביום ההוא er velkendt som udtryk for det afgørende tidspunkt, hvor Jahve griber ind (se s. 78). Isajs rodskud, שרש ישי, skal også her tolkes som den nye konge af Davids slœgt (jf. v. 1). Men som noget nyt får han en funktion i forhold til folkene. Han skal vœre et banner, der samler folkene, ganske som når feltherren samler sine soldater omkring sig før slaget. Hvem der tcenkes på med folkeslagene og folkene, עמים og גוים, er ikke helt klart, men prœeciseres i v. 12, hvor folkene, גוים, står parallelt med Israels og Judas fordrevne. Det er altså Jahves eget folk, der skal se den nye konge som et banner og samles om ham. Verbet søge, דרש , bruges i Det Gamle Testamente ofte om at søge Jahve, når man er i nød, fx SI 24,6; 34,5; 77,3, men anvendes her om kongen. Boligen betegnes som כבוד. Både mennesker, SI 8,6, og steder kan beskrives med denne glose, men den bruges ikke mindst om Jahves herlighed eller cre. I Jes 6,3 er hele jorden fyldt af Jahves כבוד, der omtales parallelt med Jahves hellighed. I SI 24,7.9 bencevnes Jahve som œrens konge, da krigerens herlighed er den œre, han vinder gennem sejren (se i øvrigt til glosen Jes 4,2 om Jahves spire og hans œre). Valget af gloser giver derfor indtryk af, at idealkongen har en scerstilling i forhold til Jahve (jf. den gammeltestamentlige kongeideologi og Messiasforestillingerne, s. 79 samt s. 174- 175).

\footnotetext{
${ }^{20}$ Jf. den redaktionelle opbygning af Davids Salmer, hvor kongedømmets fald afspejles i SI 89, den sidste salme i tredje bog, mens Jahve i fjerde bog lovprises som folkets virkelige konge, se fx SI 93; SI 96 og SI 97. Se også DKDSI, 49-50 samt Else K. Holt 2004, 21-34.
} 


\section{$11-12$}

Kapitlets anden hoveddel indledes ligeledes med udtrykket på den dag, hvilket også er med til at skabe sammenhœeng mellem de to dele. Motivet med Jahves løftede hånd er heller ikke nyt (jf. vredesudsagnene i Jes 5,25 m.fl. samt brugen af motivet om assyrerkongen i Jes 10,5.13.14), hvilket også fremgår af ordet שנית. I DO 1992 er det gengivet ved atter, men betyder egentlig for anden gang. Om der hermed tcenkes på udfrielsen fra Egypten som første gang og hjemførelsen af de fordrevne som anden gang er ikke klart, men henvisningen til Exodus i v. 16 taler for en sådan tolkning. Med glosen שיאר knyttes de fordrevnes tilbagevenden sammen med resttanken (jf. navnet på sønnen, Shearjashub i Jes 7,3 samt 10,20-21). Verbet קנה som er gengivet i DO 1992 ved genvinde betyder at købe og anvendes fx når man frikøber en slave, Neh 5,8. I Ex 15,16 og SI 74,2 løskøber Jahve Israel fra fangenskabet i Egypten (se også Jes 43,3). Vaegten ligger i Jes 11,11 på, at Jahve frikøber sine egne fra slaveforhold. Billedet siger ikke noget om, hvem han køber af og for hvor meget. Opremsningen af de steder, hvor de er blevet fordrevet hen, skal give en fornemmelse af, at de er vidt spredt ud over den kendte verden, ja helt til havets fjerne øer, der betegner den yderste grœnse for menneskeliv.

Forskerne har forsøgt at bestemme hvilke historiske begivenheder, der er tœenkt på i forbindelse med de enkelte navne, for bl.a. ad den vej at kunne datere afsnittet. Assyrien var hovedmodstanderen på Jesajas egen tid, og en del af assyrerkongens strategi bestod i deportering af nogle af de besejrede befolkningsgrupper og overflytning af folk andre steder fra, så der opstod en blandingsbefolkning. Bedst kendt er deportationen af dele af befolkningen i Nordriget efter erobringen af Samaria i 722 f.Kr. Deportationerne omtales i 2 Kong 17 og fulgtes op med tvangsflytning af folk fra andre steder i det assyriske rige til Israelområdet, 2 Kong 17,23-24 (jf. de senere stridigheder mellem jøder og samaritanere). At der boede jøder i Egypten, Patros betegner den sydlige del af det egyptiske rige, svarer ligeledes til forholdene under og efter det babylonske eksil, fx Jer 44, 1.15. Der kan bl.a. vœre tœenkt på Elefantine, en ø i Nilen tcet ved det nuvœrende Assuan, hvor der omkring 5. årh. f.Kr. var en jødisk militœrkoloni. Også בוש Nubien, hører med til det egyptiske område, og omtales i Jesajabogen i Jes 43,3; 45,14 (se også Ez 30,4.9) som områder, Jahve har magten over. Elam er et landområde i ncerheden af den persiske bugt øst for floden Tigris. Også her har der boet jøder. I Ezra 2,7 og andre steder i Ezras Bog og Nehemias' Bog nœevnes Elams efterkommere blandt dem, der vender hjem fra det babylonske eksil. Dette tyder på, at en del af de bortførte har boet i Elam. Sinear er betegnelsen for det babylonske rige, Gen 10,10; Gen 1 1,2; Zak 5, 11, som i 597 f.Kr. og 587 
f.Kr. stod bag eksileringen af judceerne. Hamat er en storby i den midterste del af Syrien, som under Sargons erobringer blev til assyrisk provins. Det er bl.a. hertil nogle af Nordrigets beboere blev tvangsforflyttet efter Samarias fald i 722 f.Kr. (se 2 Kong 17,24).

Denne opremsning giver et billede af en meget omfattende diaspora, hvor jøder lever blandt fremmede på grund af tvangsforflyttelser, som har fundet sted dels i forbindelse med Nordrigets undergang dels i forbindelse med Judas undergang. Med hensyn til dateringen må man altså konkludere, at Jes 11,10-16 må stamme fra tiden efter det babylonske eksil, men indeholder traditioner, som angår begivenheder i forbindelse med Nordrigets undergang i det 8. årh. f.Kr. Nogen prcecis datering er det dog ikke muligt at nå frem til.

Omtalen af banneret i v. 12 adskiller sig fra Jes 11,10, hvor det er kongen, der selv skal fungere som samlingspunkt. Nu er det Jahve, der rejser et banner for de adspredte jøder. Lœst i forlœngelse af Jes 11,1-10 kan banneret tolkes som den nye konge. Det er hele Jahves folk, såvel Nordriget, Israel, som Juda, der skal samles, og igen markeres det, at de kommer fra hele verden, alle fire verdenshjørner.

\section{$13-14$}

Fœllesskabet skal genetableres, og det gœlder også broderfœllesskabet mellem Efraim, Nordriget, og Juda. Forholdet mellem de to dele af det gamle Davidsrige beskrives ved flere lejligheder som direkte fjendtligt. Lœest ud fra Jesaja 1-12 konteksten er det mest iøjnefaldende eksempel naturligvis den syrisk-efraimitiske krig, hvor Efraim sammen med Syrien prøver med vold at tvinge Juda med $\mathrm{i}$ en koalition mod assyrerne, men Juda i stedet valger at støtte sig til assyrerkongen (jf. Jes 7,1-9 og kommentaren dertil). Det kan dog også vcere traditionerne om rigets deling efter kong Salomos død, der tœnkes på, 1 Kong 12, eller nogle af de andre krigeriske aktioner, som Det Gamle Testamente fortceller om, fx 2 Kong 14,8-14, hvor kongen af Juda udfordrer Nordrigets konge til kamp, men taber kampen. Også i forbindelse med genopbygningen af Jerusalem efter eksilet berettes der om stridigheder mellem de to befolkningsgrupper, samaritanerne og judceerne (se fx Neh 3,33-38 samt Zak 11,4-17). Uanset om man kan pege en enkelt situation ud som den mest sandsynlige baggrund for v. 13 eller ej, så er selve temaet broderstrid og broderjalousi et scrdeles velkendt tema i Det Gamle Testamente (jf. fx forholdet mellem Kain og Abel, Gen 4, og mellem Isak og Ismael, Gen 21 ) og broderstrid omtales netop i skildringer af, hvordan et samfund kan gå i total opløsning, Jes 9,18-20. 
Ophøret af fjendskabet skildres med vagt på gensidigheden. Vers 13 er stramt struktureret, så der først tales om ophøret af Efraims jalousi, derpå om ophøret af Judas fjendskab. I andet halvvers er det igen først Efraim, der holder op med at vœre jaloux på Juda, derpå Juda der ikke opfører sig fjendtligt over for Efraim. Den glose, der anvendes til at betegne jalousi, betegner både jalousi og lidenskab. Jahve kan i forhold til de fremmede guder netop skildres som en lidenskabelig Gud, som ikke accepterer, at hans folk dyrker andre end ham. I Ex 34, 14 hedder det: "Du må ikke tilbede nogen anden gud, for 'Lidenskabelig' er Herrens navn.", אל קנא הוא (se også Ex 20,4-5). Når det gcelder forholdet mellem brødre, er der også tale om et konkurrenceforhold. Men da er det faderens anerkendelse, det gcelder, hvad enten det er Guds velsignelse af afgrøden, Gen 4, eller faderens velsignelse til den førstefødte (jf. Esau og Jakobfortcllingen i Gen 27).

Drømmen om det nye Davidsrige kommer til udtryk flere steder i Det Gamle Testamente. I Jer 3,18 er forventningen netop, at Juda og Israel sammen skal komme til fœedrenes land. Billedligt udtrykkes fœllesskabet i Ez 34,23-24, hvor Davids skal blive hyrde over dyrene, ligesom der med tegnhandlingen i Ez 37,16-28, hvor profeten lœgger to trœstykker sammen, gives udtryk for en fœlles fremtid for de to dele af det gamle storrige (se også Am 9,11-15 om genoprejsningen af Davids faldne hytte).

Beviset på - eller er det snarere grunden til? - genoprettelsen af det gode forhold mellem brødrene er ifølge v. 14 kampen mod den fœelles fjende. Det er œrkefjender som filistrene, Edom og Moab - og mere generelt Østens folk - som de kan enes om at bekœmpe. Verset udtrykker forventningen til, hvad der skal ske, men denne forventning bygger på traditionerne om det store Davidsrige, hvor netop disse områder kom under Davids overherredømme (jf. omtalen af sejren over filistrene i 2 Sam 8, 1, over Edom i 2 Sam 8,13-14; 1 Kong 1 1,15-18 og Moab ifølge 2 Sam 8,2).

\section{$15-16$}

Afslutningsvis inddrages traditionerne om udfrielsen fra Egypten, Exodus. Igen skal Jahve gribe ind ved at svinge sin hånd og lœegge sit band på Egypterhavets vig. Roden bag verbet, at lœgge band, er חרם, der betegner at noget bliver indviet til Jahve. Genstande, der på den måde rammes af et band, skal destrueres, Deut 13,16. Også personer kan belœgges med band. Det gœelder iscr fremmede, enkeltpersoner, Jos 2,10, såvel som nationer, Jes 34,2. Personer, som rammes af bandlysning, kan ikke frikøbes, men skal dø, Lev 27,29. 
Traditionen om, hvordan Jahve fjernede vandet foran israelitterne, så de kunne gå tørskoet over Sivhavet under flugten fra Farao og hans hœr, findes i Ex 14. Ifølge Ex 14,21 rœkker Moses sin hånd ud, og Jahve udtørrer havet. I Jes 11,15 er det Jahve, der svinger med hånden (jf. Jes 10,32, hvor assyrerkongen truer Jerusalem ved at svinge med hånden). Samme tradition udnyttes i Deuterojesaja, hvor begivenhederne ved skabelsen og ved Exodus paralleliseres med forventningen til hjemkomsten fra Babylon, Jes 51,9-11. Argumentationsgangen er enkel nok. Hvad Jahve gjorde i fortiden, vil han nu gentage som en ny skabelses- og udfrielseshandling. I forbindelse med nogle af de gammeltestamentlige skabelsesforestillinger indgår tanken om en kaoskamp, der kan formuleres som en ødelœggelse af havuhyret, SI 74,13-14; 89,11, eller som en kløvning af havet, SI 136,13-14. Det er den valdige Gud, der griber ind for at skabe nyt. Betydningen af dette motiv kan også ses af beretningen om overgangen over Jordan under Josua, hvor Sivhavsunderet gentager sig (se Jos 2,10 samt Jos 3).

At motivet med udfrielsen gennem havet skal forstås billedligt fremgår af det følgende vers, der udlœgger billedet. Det er befrielsen af dem, der er i Assyrien, der sammenlignes med Sivhavsunderet. Fokus er i forlœengelse af Jes 10 på assyrerne. Udfrielsen skal i så fald ikke foregå over Egypterhavets vig (Sivhavet), men over floden Eufrat i Assyrien. I Jos 24,3 findes en tradition om, at Abrahams far, Tera, oprindelig drog fra området øst for Eufrat frem mod Kanaan (se også Gen 11,31-32 og Gen 12,1-9). Også denne tradition kan vœre med til at pege på, at Jahve vil gentage fortidens store begivenheder. Når der i v. 15 tales om, at floden spaltes i syv bakke, skal det nok ikke forstås som en prœcis geografisk angivelse. Tallet syv er et helligt tal (jf. sabbatten som den syvende dag, Gen 2,2-3, og se også den syvarmede lysestage i Ex 25,37), og her skal spaltningen i syv angive Jahves valdige magt.

At vejen hjem beskrives som en banet vej, v. 16, kendes også fra Jes 40,3-5, hvor det er hjemkomsten fra Babylon, der tœenkes på. Derimod indgår denne forestilling ikke i traditionerne om udfrielsen fra Egypten. Formålet med at omtale vejen som en banet vej, מסלה, er at vise såvel Jahves magt som Jahves omsorg for de hjemvendende (se også Jes 49,11). Vejen hjem skal vœre forberedt for dem. De hjemvendende betegnes som en rest, שאר (jf. v. 11), og netop mellem denne rest og Assyrien skabes der er en ncer forbindelse gennem ordspillet i v. 16. Ikke blot er der ordspil mellem roאשר מאר , שאר som anvendes hele to gange, og Assyrien, men ordspillet omfatter også relativpartiklen, לשאר עמו אשר ישאר מאשור. 
At det netop er de landflygtige i Assyrien, der ncevnes, peger på den tvangsdeportation, som fandt sted efter Nordrigets fald i 722 f.Kr., og runder på den måde temaet Assyrerkongens hovmod af. Ikke blot vil Jahve straffe assyrerkongen for hans hovmod, kap. 10, men de, der er tilbage efter at Jahve har brugt assyrerkongen mod dem, skal udfries. Og ingen kan vare i tvivl om, at det er Jahve selv, der styrer også denne del af historien, når det skal ske, ligesom dengang Israel drog op fra Egypten. Det er derfor velanbragt, når redaktionen lader en takkesalme afslutte de første tolv kapitler af Jesajabogen.

Tilbage til indholdsfortegnelsen

\section{Jes 12}

\section{Tekstkritik}

$2 a b$

Gudsnavnet er gengivet dels med den korte form יה, יהוה I dels med 1992 er kortformen fjernet. Ordret betyder MT: "min styrke og Jahs lovsang er Jahve". Den grceske overscettelse, LXX, har kun Herren én gang, og det er tœenkeligt, at Jahve er tilføjet som en forklaring til den sjœldne form Jah. Til fordel for denne forklaring taler desuden, at det første bogstav i Jah, nemlig ', egentlig burde høre til det forudgående ord som suffix for 1. pers. sing. Flyttes bogstavet ', så kommer der til at stå: יוזמרת, dvs. min lovsang, hvilket giver en klar parallel til עזי. Jf. BHS a og b. DO bør derfor følges her.

\section{Karakteristik}

Kap. 12 er i sin ydre form en takkesalme (se ncermere om denne Gattung i DKDS II, 111-114 om SI 30), men med elementer fra den profetiske genre. Til den profetiske genre hører udtrykket på den dag, ביום ההוא, (jf. faktaboksen s. 78). Med dette udtryk deles salmen i to dele, v. 1-3 og v. 4-6. Salmen begynder som en individuel takkesalme med 1. person ental, men anvender 2. person flertal fra og med v. 3. Det kan nceppe afgøres, om salmen har eksisteret som en selvstcndig salme, som i begrcenset omfang er blevet redigeret m.h.p. placeringen i Jesajabogen (evt. blot i form af tilføjelsen af "på den dag skal du/l sige" i v. 1 og v. 4), eller om salmen er skrevet direkte til at afrunde Jes 1-11. Uanset tilblivelseshistorien er dens funktion at runde de første 11 kapitler af og give folket lejlighed til at reagere på den forkyndelse, som disse kapitler indeholder.

Når redaktorerne har valgt at placere en takkesalme her, kaster det lys over deres opfattelse af forkyndelsen forud. Takkesalmer følger liturgisk efter bønssalmer, hvad enten takkesalmen ind- 
går som en del af en bønssalme (jf. SI 22, hvor første del er bøn og klage, v. 2-22a, mens anden del er takken for befrielse fra nøden, v. 22b-32), eller den fremstår som en selvstcendig salme i Salmernes Bog, fx SI 30. Selv om Jesaja 1-11 ikke er formet som en bønssalme, så formidler de mange trusler og domsorakler en situation, der svarer til bønssalmens nødssituation. Folket, der står under anklage for at have svigtet Jahve, Jes 1,2-3, kommer ikke til orde med noget forsvar, for der er ikke noget at sige til deres forsvar. Men de kommer heller ikke til orde med et råb til Jahve om hjœlp! Hvad der fortcelles i Denkschrift er da også, at de forhœrder sig og lukker af for forkyndelsen. Først da Jahve lover en ny tid, kommer der en reaktion. Det sker i form af en takkesalme, der giver udtryk for taknemmelighed og glcede over, at Jahve selv er vendt om fra sin vrede og nu trøster og frelser, kap. 12. Temamœssigt er salmen ncert forbundet med de foregående kapitler, idet centrale udtryk og billeder let lader sig tyde ud fra Jes 1-11.

Temamcessigt passer salmen også godt ind i Jesajas teologi i bredere forstand. Dens understregning af, at vreden var en realitet, men blev afløst af den positive trøst, svarer til de to hovedtemaer i Protojesaja, Jes 1-39, og Deuterojesaja, Jes 40-55: Først kom vreden med Guds dom og straf, som Jes 1-39 giver udtryk for, så kom trøsten, som er hovedtemaet i Jes 40,1: "Trøst mit folk, trøst det!" Et formål med salmen kan derfor også vœre at skabe forbindelse videre til Deuterojesaja.

Endelig må det nœvnes, at profeti og salmedigtning har mange formelle ligheder med hinanden. Som tidligere nœvnt står mange profetiske udsagn, ligesom de fleste salmer, uden nogen form for rammefortclling. De har derfor kunnet bruges i forskellige situationer, og det poetiske sprog har vœret velegnet til at blive tolket ud fra forskellige ydre forhold.

\section{Struktur}

v. 1-3: Opfordring til at takke Jahve på den dag, fordi vreden blev afløst af trøst.

v.4-6: Opfordring til at takke Jahve på den dag og forkynde hans store gerninger.

\section{Fortolkning}

$1-3$

Udtrykket, på den dag, v. 1, forbinder salmen med det foregående kapitel, der bruger samme formel, Jes 1 1,10.11. Redaktorerne har ønsket, at kap. 12 skulle lœeses i direkte forlœngelse af det foregående kapitels frelsesforkyndelse. ביום ההוא betegner den dag, hvor Jahve griber ind. Om Jahves komme bliver til dom eller frelse afhcenger af situationen. I Jes 12 er det en dag til frelse for beboer- 
ne i Jerusalem. At man generelt har betragtet Jahves komme som noget positivt, fremgår også indirekte af Am 5,18, hvor profeten advarer mod at lcenges efter Herrens dag i tillid til, at den er lys. De skal opleve, at den er mørk. I Jes 2,12-17 er den dag anvendt om en dag, hvor de stolte skal ydmyges, og i Jes 13,6.9 er Herrens dag en dag, der medfører ødeløggelse og radsel. Det er altså forestillinger, som handler om Jahves aktive indgriben i historien, og som i Jes 12,1.4 anvendes positivt. Dagens positive indhold beskrives gennem den reaktion, som salmisten opfordres til at komme med. Han skal bryde ud i takkesang.

Guds vrede og trøst sammenfatter den situation, salmisten har gennemlevet. Lœst uafhcengigt af den nuvœrende kontekst ville Guds vrede vœre et meget åbent billede. Guds vrede kan give sig udslag i forskellige former for nød: sygdom, tab af social anseelse, falske anklager og lignende. Lœst i forlcengelse af Jes 1-11 er det ikke en enkeltpersons lidelser, men folkets, der skal tœnkes på. Og da kan vreden vœre udtryk såvel for de politiske fjenders hcergen (ikke mindst assyrerkongens) som for Jahves forhcerdelse af sit folk. Jahves vrede, א, er et gennemgående motiv i kapitlerne omkring Denkschrift. Her hedder det, at Jahves vrede er flammet op mod hans folk, אף־יהוה, men til trods for den straf, folket allerede har fået, så har hans vrede, אפו, endnu ikke lagt sig, Jes 5,25. Som et omkvaed fortscetter vredesmotivet i Jes 9,11.16.20 samt 10,4, og videreføres med assyrerkongen som Jahves vredes kœp, שבט אפי, i Jes 10,5. At vreden ikke skal vare evigt fremgår dog af Jes 10,25, som taler om straffen over den hovmodige assyrerkonge: "For det varer kun kort tid, før vreden er forbi; så skal min harme tilintetgøre dem." Vreden mod Jahves eget folk skal vendes til harme mod assyrerne.

שוב Verbet, som i Jes 12,1 bruges om, at Jahve vender sin vrede, er det samme verbum, som indgår i navnet på Jesajas søn, Shearjashub, שאר ישוב, en rest vender om. Man kunne overveje, om det hermed også antydes, at ikke kun folket skal vende om, Jahve kan også vende om.

At vreden ikke varer evigt er indirekte et svar på det klagende spørgsmål, som kendes fra bønssalmerne: "Hvor lœenge vil du dog vœre vred, Herre, hvor lœnge skal din lidenskab brœende som ild?", SI 79,5, eller som det hedder i SI 85,6-7: "Vil du vare vred på os for evigt, skal din vrede vare i slœgt efter slœgt? Vil du aldrig give os liv igen, så dit folk kan glœde sig over dig?".

Jahves trøst står som modsctning til vreden. Verbet נחם, at trøste, betegner ikke blot trøstende ord, men hjœlp i nøden. Hvad der trøster hjorden i SI 23,4 er da også hyrdens stok og stav, dvs. de redskaber, han bruger til at forsvare sine dyr med og til at indfange dem, der forvilder sig, så de ikke skal komme til skade i det vanskelige terrœen. Når motivet trøst spiller så stor en rolle i den deuterojesajanske forkyndelse, Jes 40-55, tœnkes der heller ikke blot på smukke, trøstende ord, men på at 
Jahve vil bringe sit folk hjem fra eksilet (se fx brugen af verbet trøste i Jes 40,1; 49,13; 51,3; 52,9; $66,13)$

Med v. 2 indføres ordet frelse, ישועה, der herefter bruges endnu én gang i v. 2 samt én gang i v. 3. Dette er overraskende mange gange inden for kun 6 vers, ikke mindst set i lyset af, at hverken substantivet ישועה anvendes i Jes 1-11. Roden findes dog i form af egennavnet, ישע ישיהו Jesaja. Profetens navn, som anføres i overskrifterne i Jes 1,1 og 2,1, og ncevnes i 7,3.13, betyder, Jahve frelser. Som overskrift og som led i beretningen om, hvordan Jahve sender profeten med frelsesbudskab til kong Akaz, giver navnet en nøgle til forståelse af Jahves egentlige vilje med sit folk. I Jes 8,18 betegner profeten ikke blot sine børn, men også sig selv som "tegn og varsler i Israel". Det er altså ikke kun Shearjashub, Jes 7,3, og Maher-Shalal Hash-Baz, Jes 8,3, der har symbolnavne, det gœelder også Jesaja.

At Gud er den bedendes frelse skal forstås meget konkret. Det er ikke en åndelig form for frelse, men befrielse fra deres fjender. Som reprœsentant for folket kan han takke, fordi de er blevet reddet fra den totale undergang. Derfor kan han vare tryg. Verbet בטח betegner tillid og sikkerhed. Modsctningen er angsten, som nu er forbi (jf. Jes 2,10.19.21 hvor angsten for Jahve skal få de hovmodige til at skjule sig). Begrundelsen er, at Jahve giver ham styrke og grund til at lovsynge. For Jahve frelste ham. Verset begynder og slutter med frelsesmotivet.

Opfordringen i v. 3 til at øse vand kan ses som en replik til Jes 8,6. Nu skal de ikke lœengere forkaste det levende vand, Jahve, men med glœde tage imod hans frelse. Vand er metafor for det livgivende. Rent fysisk er vand nødvendigt for at overleve, og billedligt kan det bruges om Gud selv (jf. Jer 2,13: "De har forladt mig, en kilde med levende vand...".) Om der bag ordene her i Jes 12,3 også ligger bestemte vandøsningsriter er vanskeligt at afgøre. I 1 Sam 7,6 omtales en sådan rite i forbindelse med en fastedag, hvor israelitterne bekender, at de har syndet mod Jahve. Hvis dette ligger bag ved, får vandøsningen i Jes 12,3 et positivt udtryk, når vandet kaldes frelsens kilder, og selve handlingen er forbundet med glcede.

\section{4-6}

I salmens anden del gentages formlen fra v. 1, men nu henvendt til flere, som opfordres til at takke Jahve og påkalde hans navn. Navnet og personen hcenger nøjes sammen. I den deuteronomistiske teologi bruges hyppigt glosen שם, navn, i stedet for ordet Gud eller Jahve (se fx Deut 12,11 om nav- 
net og helligstedet samt 1 Kong 8,17-20.27-30 om Guds ncervar i form af navnet i Salomos tempel). Hvor navnet er, dér er Gud selv tilstede.

Fra takkesalmerne kendes det motiv, at salmisten vil forkynde for andre, hvordan Jahve har grebet ind og hjulpet. I SI 22,23-32 lover salmisten at forkynde Jahves navn for menigheden, ja, forkynde om Jahve for hele den vide jord, i al tid og for de døde, de levende og de kommende slagter. Samme universalistiske holdning kommer til orde i Jes 12,4 og svarer godt til universalismen i Jes 2,1-5. Det er Jahves gerninger, der er årsag til, at alle skal høre om Jahve.

At Jahves navn er ophøjet svarer til Jes 2,11.17. Men hvor Jahves ophøjelse i kap. 2 er forbundet med ydmygelsen af mennesket, så er dette motiv ikke til stede i kap. 12. Ydmygelsens tid er forbi.

Med v. 5 gentages motivet med Jahves store gerninger, der skal forkyndes for hele verden. Med verbet ממר bliver det tydeligt, at vi er i salmegenren. I Davids Salmer opfordres menigheden igen og igen til at lovsynge Gud, fx SI 30,5; 47,7; 81,3; 98,5.

Salmen slutter med en opfordring til יוישבת ציון, der egentlig betyder Zions beboer (i hunkøn), men her er brugt kollektivt om beboerne i Jerusalem. Fokus er igen Zion og dermed den rest, Jahve har skånet, og som har grund til at juble af glœde. Dette minder om Jes 1,8, hvor Zions datter er tilbage som en hytte i en vingård. Omtalen af Jahve som Israels Hellige peger tilbage på Jes 6,3, hvor Guds hellighed prises af seraferne i Jesajas vision. Hellighed er en vigtig del af det jesajanske gudsbillede. Men hvor helligheden gav anledning til frygt i Jes 6, er den her årsag til jubel. Som hellig tåler Jahve ikke menneskers ondskab, men nu er ondskaben forbi (jf. Jes 11,9, hvor fravœr af ondskab på det hellige bjerg hører med til den nye tid).

Salmen er prceget af Zionteologi og bygger på samme tradition som Zionsalmerne. Jahve har udvalgt sig Jerusalem som det sted, hvor han er nœervarende med sin velsignelse. Derfor vil han også beskytte sin by mod fjenderne (jf. folkekampmyten, SI 46 og 48).

Jes 1-12 begynder med en prolog, Jes 1,1-2,5, hvor de vigtigste motiver i den jesajanske forkyndelse prœsenteres (se s. 20). I en vis forstand er Jes 12 en epilog, der samler op og sctter de første kapitler i perspektiv. Det sker i form af en takkesalme, der viser, at situationen er totalt œndret. Straffen er forbi, Jahve har grebet ind og reddet Jerusalem. Og det folk, som før var forhcerdede, Jes 6, og havde lukket af over for Jahves ord, de kan nu ikke blot se, høre og fatte Jahves store gerninger, men også selv udtrykke glœde og taknemmelighed over dem. 
En sådan taknemmelig gløede passer godt til redningen af Jerusalem i 701 f.Kr., hvor Sankerib ikke havde held til at erobre byen. På det tidspunkt beviste Zionteologien sin trovœrdighed, og Jesajaprofetierne fik som følge heraf autoritet. Hvad profeten havde forkyndt, det var gået i opfyldelse, både de hårde ord om, at Jahve ville straffe sit folk og decimere det til en rest, og løfterne om en ny tid, hvor Jerusalem blev reddet af Gud selv. Så meget desto større blev forfœrdelsen og fortvivlelsen, da Jerusalem godt 100 år senere blev erobret og ødelagt af babylonerne. Men den jesajanske forkyndelse blev bevaret og videreført i håbet om, at frelsesforkyndelsen stadig stod ved magt, selv om Jahves vrede endnu ikke havde lagt sig. For engang vil der fødes en virkelig Messias, som skal genoprette Davids rige og sikre fred og livsudfoldelse.

Tilbage til indholdsfortegnelsen

\section{UDBLIK TIL JES 40}

Som tidligere nœvnt er der generelt enighed blandt forskerne om, at Jesajabogen er resultatet af et lœngerevarende redaktionsarbejde (se s. 32-35). Jesajas forkyndelse tog sin begyndelse i anden halvdel af 8. årh. f.Kr. i en politisk turbulent tid. Hans forkyndelse er praget af dom over folket p.g.a. dets frafald fra Jahve, men også af et håb for en rest. Forskerne har diskuteret, om både dom og frelse hører med til det oprindelige budskab, eller frelsesoraklerne er senere tilføjelser. Som det gerne skulle vœre fremgået af kommentaren til de første tolv kapitler, tyder ikke mindst det anvendte billedsprog på, at forbindelsen mellem dom og frelse er en central del af budskabet. Nok fœldes trœet, men det kan spire igen. Hos Jesaja er der håb for et trœ.

Den jesajanske forkyndelse fra 8. årh. f.Kr. har levet videre og er i 6. årh. f.Kr., dvs. under og efter det babylonske eksil, blevet suppleret med det, vi kalder Deuterojesaja, Jes 40-55. Samtidig hermed er der sket en redigering af de forudgående kapitler. Hvem, der står bag forkyndelsen i Jes 40-55, vides ikke. Navnet Deuterojesaja er et kunstord, der blot skal vise, at der er tale om en senere form for jesajansk forkyndelse. Centrum i den deuterojesajanske forkyndelsen er løftet om den nye tid, som er på vej med eksilets ophør, de bortførtes tilbagevenden, Jes 40,9-11; 51,11, og genopbygningen af Jerusalem, Jes 44,28; 54,11-12. Deuterojesaja er overbevist om, at Jahve er en Gud, der både kan føre i eksil og føre ud af eksil, for det er den samme Gud, der danner lys og skaber mørke, Jes 45,7. Og ganske som Jahve dengang straffede den hovmodige assyrerkonge, Jes 10, vil hans straf nu ramme det selvsikre Babylon, Jes 47. 
Det har i eksiltiden vœret vigtigt at fastholde tilliden til, at Jahve er herre over både ulykke og lykke. Den jesajanske forkyndelse fra 8. årh. f.Kr. byggede i høj grad på Zionteologien og dens hœevdelse af, at Jahve for evigt ville beskytte sin by og sin konge. Zionteologien var uden tvivl blevet styrket, da Sankerib i 701 f.Kr. opgav belejringen af Jerusalem, men den fik et afgørende kncek, da Jerusalem faldt i 587 f.Kr. Derfor blev det aktuelt at overveje, om Jahve havde mistet sin magt til de fremmede guder, eller om Jahve havde glemt sit folk? På forskellig vis giver Deuterojesaja svar på disse spørgsmål.

I sammenligning med de babylonske guder er Jahve ifølge den deuterojesajanske forkyndelse den aktive Gud, der kan gribe ind i historien, og som kan forudsige fremtiden. De babylonske guder kan intet stille op over for Jahve. Ved at bruge retstaleformen kan Deuterojesaja vise, at de fremmede guder er ude af stand til at fremlœgge beviser på deres egne evner, når Jahve indkalder til retssag. Hvor retstaleformen i Jes 1-12 blev anvendt mod Jahves eget folk, bruges den mod de fremmede guder i fx Jes 41,21-29 og 43,8-13. På spørgsmålet om, hvem der har magten, svarer Deuterojesaja, at det beviseligt er Jahve og ingen anden.

Et lige så relevant spørgsmål i denne sammenhœng har vœret, om Jahve ud over at vœre magtfuld også er retfœrdig. Og svaret på dette spørgsmål gives i høj grad i Jes 1-39, Protojesaja, hvor det igen og igen påvises, at folket er faldet fra deres egen Gud, og at de i stedet har sat deres lid dels til sig selv dels til fremmede magter.

At Jahve både havde magten og handlede retfœrdigt ved at straffe sit eget folk, var dog ikke tilstrckkeligt svar på spørgsmålet om, hvorvidt Jahve efter afstraffelsen blot havde glemt sit folk. Men her bruges $\mathrm{fx}$ billedet af en ung mor til at forsikre de tvivlende om, at Jahve stadig har omsorg for dem.

Men Zion siger: "Herren har svigtet mig,

Herren har glemt mig!"

Glemmer en kvinde sit diende barn?

Glemmer en mor det barn, hun fødte?

Selv om de skulle glemme,

glemmer jeg ikke dig.

Se, i mine hcender har jeg tegnet dig, dine mure har jeg altid for øje. 
De, der skal genopbygge dig, er hurtigt på vej,

de, der rev dig ned og lagde dig øde,

drager bort fra dig. Jes 49,14-16.

Deuterojesaja tolker eksilet som straf for folkets synd. Men nu er straffen forbi (jf. vredens ophør og takken for frelse i Jes 12), og tiden er inde til at trøste folket, sådan som det lyder straks fra begyndelsen: "Trøst mit folk, trøst det! siger jeres Gud.", Jes 40,1. Straffen var den nødvendige forudscetning, ja, Jerusalem har endog fået dobbelt straf af Jahves hånd for alle sine synder, Jes 40,2. Tegnet på den nye tid er de bortførtes hjemvendelse fra Babylon, Jes 40,9-11, og genrejsningen af Jerusalem, Jes 51,1-52,12.

Fortiden er prœget af folkets synd, nutiden af dets lidelse; men når lidelsen er straf og dermed betaling for fortidens synder, så er der håb for fremtiden. Det er i den sammenhceng man skal forstå Deuterojesajas brug af tjenerbilledet. ${ }^{21}$ Tjeneren lider, men hans lidelse er meningsfuld og ikke absurd. Ud af de fire poetiske tekster om Herrens tjener, Jes 42,1-4; 49,1-6; 50,4-9 og 52,1353,12 , er ikke mindst den sidste med til at understrege den positive rolle tjeneren har. Det er her man finder den sœrlige tolkning af tjenerens lidelse, at den er soning for andres synd. Hvem denne tjener er billede på, står stadig til diskussion. Men lœest i den littercere helhed, som Jesajabogen skaber, giver det god mening at se de eksilerede som dem, der lider for fortidens synder, og dermed soner også for dem, der blev tilbage i Juda og slap for at blive ført i fangenskab.

Ordene "Men han blev gennemboret for vore overtrcedelser og knust for vore synder. Han blev straffet, for at vi kunne få fred, ved hans sår blev vi helbredt.", Jes 53,5, er siden blevet tolket om Kristus, men i datidens kontekst var det folkets egne erfaringer, der kom til udtryk gennem et markant billedsprog.

Forventningerne til fremtiden er meget konkrete: De eksilerede skal hjem og bygge Jerusalems ruiner op. Fremtiden derhjemme beskrives udførligt, men om fortiden siges kun formelagtigt, at Gud for en kort tid forlod dem, Jes 54,7-8, at de var troløse, Jes 48,8, og at de blev udleveret til plyndring og til røvere, Jes 42,24.

Der findes ikke som i Ezekiels Bog en grundig beskrivelse af folkets synd $\mathrm{i}$ form af afgudsdyrkelse, men indimellem taler Deuterojesaja om "det der skete tidligere", ראנית:, Jes 43,18.

\footnotetext{
${ }^{21}$ Se nœrmere til den deuterojesajanske forkyndelse og tjenerbilledets betydning og funktion i Kirsten Nielsen 1998.
} 
Hvad der tcenkes på med de tidligere begivenheder er blevet tolket forskelligt. Nogle har ment, at det er de store frelseshistoriske begivenheder som Exodus, andre at det er domsprofeternes forudsigelser af eksilet.

En anden måde at forstå udtrykket på er at tolke det ud fra den littercre sammenhœng, nemlig ud fra Jesajabogen som bog. ${ }^{22}$ I så fald kan udtrykket henvise til det, der fortclles om i første del af bogen, Jes 1-39. Da de to tekstsamlinger, Jes 1-39 og Jes 40-55, blev samlet til én bog, redigerede kredsen omkring Jes 40-55 også disse første 39 kapitler på en sådan måde, at de kunne fungere som en indledning til den deuterojesajanske forkyndelse. Denne Deuterojesajakreds bliver dermed en form for "udgivere" af Jes 1-39 i moderniseret udgave, så den del af bogen kan danne baggrund for forkyndelsen til de eksilerede og til dem, der var tilbage i Jerusalem. Domsforkyndelsen i Jes 1-39 og den straf de selv erfarede i forlœengelse deraf, under eksilet, bliver dermed bevis på, at Jahve er historiens herre.

Man må derfor regne med, at der i forlœengelse af profeten Jesajas forkyndelse i 8. årh. f.Kr. har varet en gruppe disciple og tilhœengere, som har bevaret forkyndelsen (jf. at Jes 8,16 taler om at Jesaja vil forsegle sin profeti hos disciplene, og så må de afvente, hvornår den skal gå i opfyldelse). Denne kreds af Jesaja-tilhcengere har dog ikke tiet stille, men har givet traditionen om hans ord og handlinger videre. I eksiltiden trœngte man alvorligt til at se sammenhœeng i tilvarelsen, og nu kunne disse Jesaja-tilhcengere udpege den ønskede sammenhœeng ved at fremdrage Jesajas forkyndelse, tolke den og tilrettelœgge den ud fra den nye situation. Det er ikke muligt endeligt at afgøre, hvor meget denne "Deuterojesajakreds" har redigeret i Jes 1-39. Men de har naturligvis haft brug for såvel domsforkyndelsen som håbet i Protojesaja for at kunne tale trovœrdigt om deres fremtidshåb. Man må derfor forestille sig en form for deuterojesajansk genlœsning af Protojesaja. Deuterojesaja er blevet til i dialog med Protojesaja, og Protojesaja har varet udsat for en vis deuterojesajansk tilrettelœggelse. Kredsen bag Deuterojesaja har bygget videre og styrket sin autoritet ved at genbruge Protojesaja, og de har videregivet den protojesajanske forkyndelses hovedindhold i tillid til, at profettekster ikke uden videre bliver passé. For bag ordene og løfterne står den samme Jahve, som talte gennem profeten Jesaja.

Formålet med forkyndelsen i Deuterojesaja er derfor at genskabe tilliden til Jahve, så folket vender om og dermed realiserer, hvad der lå i navnet שאר שוב, en rest vender om/tilbage, Jes 7,3.

\footnotetext{
${ }^{22}$ Se ncrmere om relationen mellem Proto- og Deuterojesaja i Knud Jeppesen 1987, 63-84, eller i senere vœrker som Christopher R. Seitz 1993, 2.
} 
Men netop derfor er det vigtigt at genbruge profetier fra den profet, der selv baerer navnet ישעיהו, Jahve frelser. ${ }^{23}$

Tilbage til indholdsfortegnelsen

\section{LITTERATURLISTE MED RELEVANS FOR KOMMENTAREN}

\section{Kommentarer til Jesajabogen}

Brueggemann, Walter 1998. Isaiah 7-39. Louisville, Kentucky: John Knox Press.

Childs, Brevard S. 2001. Isaiah (The Old Testament Library). Louisville - London - Leiden:

Westminster John Knox Press.

Duhm, Bernhard 1892. Das Buch Jesaia. Übersetzt und erklärt von Bernhard Duhm. 4. neu durchgesehene Auflage. Göttingen: Vandenhoeck \& Ruprecht 1922.

Dunn, James D.G. \& John W. Rogerson (eds.) 2003. Eerdmans Commentary on the Bible. Grand Rapids, Michigan / Cambridge, U.K.: Wm. B. Eerdmans Publishing Co.

Hanson, Paul D. 1995. Isaiah 40-66 (Interpretation. A Bible Commentary for Teaching and Preaching). Louisville: John Knox Press.

Jeppesen, Knud 1988. Jesajas Bog fortolket. København: Det danske Bibelselskab.

Mays, James L. (general editor) 1988. Harper's Bible Commentary. San Francisco: Harper \& Row. Miscall, Peter D. 2006. Isaiah (2 ${ }^{\text {nd }}$ Edition. $1^{\text {st }}$ Edition 1993) Sheffield: Sheffield Phoenix Press.

Seitz, Christopher R. 1993. Isaiah 1-39 (Interpretation. A Bible Commentary for Teaching and Preaching). Louisville: John Knox Press.

Wildberger, Hans 1972. Jesaja. I. Teilband Jesaja 1-12. (Biblischer Kommentar Altes Testament, Band $\mathrm{X} / 1$ ). Neukirchen-Vlyun: Neukirchener Verlag.

\section{Kommentarer til Davids Salmer}

Holt, Else K. og Kirsten Nielsen (red.) 2002. Dansk Kommentar til Davids Salmer I-III, Frederiksberg: Forlaget ANIS. (Forkortet DKDS).

Holt, Else K. 2004. Kommentar til Salmernes Bog. København: Det Danske Bibelselskab.

${ }^{23}$ Jf. Jes 1,1 samt udfoldelsen af navnets betydning i Jes 12,2: "Gud er min frelse". 
Monografier til Jesajabogen

Barton, John 1996. Isaiah 7-39. (Old Testament Guides). Sheffield: Sheffield Academic Press.

Blenkinsopp, Joseph 2006. Opening the Sealed Book. Interpretations of the Book of Isaiah in Late Antiquity. Grand Rapids, Michigan / Cambridge, U.K.: William. B. Eerdmans Publishing Company.

Gitay, Yehoshua 1991. Isaiah and his Audience. The Structure and Meaning of Isaiah 1- 72 (Studia Semitica Neerlandica). Assen, The Netherlands: Van Gorcum \& Comp.

Jeppesen, Knud 1987, Grceder ikke saa saare. Studie i Mikabogens sigte. Århus: Aarhus Universitetsforlag.

Kelle, Brad E. \& Megan Bishop Moore (eds.) 2006. Israel's Prophets and Israel's Past. Essays on the Relationship of Prophetic Texts and Israelite History in Honor of John H. Hayes. New York - London: T \& T Clark.

Leclerc, Thomas L. 2001. Yahweh is Exalted in Justice. Solidarity and Conflict in Isaiah. Minneapolis: Fortress Press.

Lemche, Niels Peter 1984. Det gamle Israel. Det israelitiske samfund fra sammenbruddet af bronzealderkulturen til hellenistisk tid. Århus: Forlaget ANIS (4. udg. 1991).

Lemche, Niels Peter 2008. Det Gamle Testamente mellem teologi og historie. Den historisk-kritiske bibelforsknings storhed og fald, Frederiksberg: Anis.

Miller, J. Maxwell \& John H. Hayes 2006. A History of Ancient Israel and Judah. $2^{\text {nd }}$ Edition. Louisville - London: Westminster John Knox Press.

Moyise, Steve \& Maarten J.J. Menken (eds.) 2005. Isaiah in the New Testament (The New Testament and the Scriptures of Israel). London - New York: T \& T Clark International.

Nielsen, Kirsten 1977. Jahve som anklager og dommer. Aarhus: TeolTryk.

Nielsen, Kirsten 1978. Yahweh as Prosecutor and Judge. Sheffield: JSOT Press (revideret udgave af Kirsten Nielsen 1977).

Nielsen, Kirsten 1985. For et trce er der håb. Om trceet som metafor i Jes 1-39. København: Gad. Nielsen, Kirsten 1989. There is Hope for a Tree. The Tree as Metaphor in Isaiah. Sheffield: JSOT Press (revideret udgave af Kirsten Nielsen 1985).

Nielsen, Kirsten 1998. Bilderna och Ordet. Om Herrens tjänare och andra bilder i Gamla testamentet. Örebro: Bokförlaget Libris. 
Nielsen, Kirsten 2003. Det Gamle Testamente på qudstjenestens betingelser. Introduktion til de gammeltestamentlige lassninger efter anden tekstrcekke med sproglige noter af Martin Ehrensvärd, Frederiksberg: ANIS.

Nielsen, Kirsten 2004. Barn Jesus i en krybbe lå, Det Danske Bibelselskab, København.

Otzen, Benedikt 1977. Israeliterne i Palcestina. Det gamle Israels historie, religion og litteratur. København: G.E.C. Gad.

Sawyer, John F.A. 1996. The Fifth Gospel. Isaiah in the history of Christianity. Cambridge: Cambridge University Press.

Seitz, Christopher R. 1991. Zion's Final Destiny. The Development of the Book of Isaiah. A Reassessment of Isaiah 36-39. Minneapolis: Fortress Press.

Sweeney, Marvin A. 2005. The Prophetic Literature. (Interpreting Biblical Texts). Nashville: Abingdon Press.

Wagner, Thomas 2006. Gottes Herrschaft. Eine Analyse der Denkschrift (Jes 6, 1-9,6). Leiden Boston: Brill.

Wildberger, Hans 1984. Königsherrschaft Gottes. Jesaja 1-39. Teil 1. Das Buch. Der Prophet Jesaja und seine Botschaft. Neukirchen-Vluyn: Neukirchener Verlag.

Artikler

Gottlieb, Hans 1986. 'Text, filologi og gengivelse. Jes 7,14.' In: Tekster og Tolkninger - ti studier i Det gamle Testamente. Redigeret af Knud Jeppesen og Frederick H. Cryer, Forlaget Anis, Århus V.

Høgenhaven, Jesper 1999. 'Historien om profeterne - og profeterne i historien. Nogle bemcrkninger om de gammeltestamentlige profetbøger som historieskrivning'. In:

G. Hallbäck og J. Strange (red.), Bibelog historieskrivning (Forum for bibelsk eksegese 10), København, 103-115.

Høgenhaven, Jesper 2008. 'Politik og profeti i Det Gamle Testamente.' Bibliana 9,2,13-21. Jeppesen, Knud 1989. 'Herrens tjener og Herrens tjenere. Om Jes 40-66.' In: Bent Rosendal (red.), Studier i Jesajabogen. Tilegnet Benedikt Otzen, 16. december 1989. Århus: Aarhus Universitetsforlag, 68-93.

Nielsen, Kirsten 1976. 'Profeternes opgør med kulten.' Dansk Teologisk Tidsskrift 4, 217-30.

Nielsen, Kirsten 1978. 'Det gammeltestamentlige gudsbillede belyst ud fra de profetiske retstaler.' 
Dansk Teologisk Tidsskrift 2, 90-106.

Nielsen, Kirsten 1986. 'De siger om mig, at jeg altid bruger billeder.' In: Tekster og tolkninger. Ti studier i Det gamle Testamente. Redigeret af Knud Jeppesen og Frederic Cryer, Forlaget ANIS, Aarhus, 101-12.

Nielsen, Kirsten 1989. '” skal høre og høre, men intet fatte; I skal se og se, men intet forstå." Jesajas kaldelsesberetning set i lyset af de senere års profetforskning.' Studier i Jesajabogen. Tilegnet Benedikt Otzen, 16. december 1989. Redigeret af Bent Rosendal, Aarhus Universitetsforlag, Århus, 9-29.

Nielsen, Kirsten 2000. 'Intertextuality and Hebrew Bible.' In: A. Lemaire \& M. Scebø (eds.), Congress Volume Os/o 1998. Leiden - Boston - Köln: E.J. Brill, 17-31.

Nielsen, Kirsten 2005, 'Jeg er som en løve for Efraim. Overvejelser over dyrebilleder og gammeltestamentlig teologi.' In: Nomen et Nomina. Festskrift till Stig Norin, Svensk Exegetisk Årsbok 70, På uppdrag av Uppsala Exegetiska Sällskap utgiven av Kari Syreeni, Uppsala, 215-227.

Nielsen, Kirsten 2006. 'Ezekiels kaldelsesvision som prolog. Fra kompleksitet og foranderlighed til orden og stabilitet.' Dansk Teologisk Tidsskrift 69, 14-28.

Otzen, Benedikt 1986. '"Hvis jeg glemmer dig, Jerusalem...". Jesaja 2,2-5 og Sionideologien.' In: Tekster og Tolkninger - ti studier i Det gamle Testamente, redigeret af Knud Jeppesen og Frederick H. Cryer, Forlaget Anis, Århus V.

Sheppard, Gerald T. 1988. 'Isaiah 1-39. Introduction'. In: Mays, James L. (general editor). Harper's Bible Commentary. San Francisco: Harper \& Row, 542-549.

\section{Opslagsvaerker og håndbøger}

Hallbäck, Geert og Hans Jørgen Lundager Jensen (red.) 1998. Gads Bibelleksikon A-K; L- ,

I redaktionen: Bertil Wiberg. Redaktionssekretcr: Bodil Ejrnœes. Konsulent for arkœologi og geografi: John Strange, København: Gads Forlag. (Forkortet GBL).

Jensen, Hans Jørgen Lundager 1998. Gamme/testamentlig religion. En indføring. Frederiksberg: Forlaget ANIS.

Holt, Else Kragelund og Kirsten Nielsen 1999 (red.), Bibelkundskab. Introduktion til Det Gamle Testamente. 2. reviderede oplag. Århus: Aarhus Universitetsforlag. 